\title{
ESTUDO DA RELAÇÃO KI(Ca+Mg) E DIAGNOSE POR SUBTRAÇÃO DE P, S E MICRONUTRIENTES EM SOLOS CALCÁRIOS DA MICRORREGIÃO DE IRECÊ-BA
}

\author{
Washington Luiz Cotrim Duete \\ Engenheiro Agrônomo
}

Orientador: Prof. Dr. Euripedes Malavolta

Tese apresentada à Escola Superior de Agricultura "Luiz de Queiroz", da Universidade de São Paulo, para obtenção do título de Doutor em Agronomia, Área de Concentração: Solos e Nutrição de Plantas.

PIR A CICAB A

Estado de São Paulo - Brasil

Novembro de 1995 
Dados Internaciona is de Catalogação na Publicação (CIP)

DIVISÃO DE BIBLIOTECA E DOCUMENTACÃO - CampUs "Luiz de Queiroz"/USP

Duete, Washington Luiz Cotrim

Estudo da relação $K /(\mathrm{Ca}+\mathrm{Mg})$ e diagnose por subtração de $P$, $S$ e micronutrientes em solos calcários da microrregiăo de Irecè-BA. Piracicaba, 1995.

134p. ilus.

Tese - ESALQ

B ibl iografia.

1. Feijão - Nutrição 2. Micronutriente em solo - Irecé, BA

3. Relação solo-planta - Irecê, BA 4. Solo - Química - Irecê, BA

I. Escola Superior de Agricultura Luiz de Queiroz, Piracicaba

CDD 635.652

631.41 


\section{ESTUDO DA RELAÇÃO KI(Ca+Mg) E DIAGNOSE POR SUBTRAÇÃO DE P, S E MICRONUTRIENTES EM SOLOS \\ CALCÁRIOS DA MICRORREGIÃO DE IRECÊ-BA}

\section{WASHINGTON LUIZ COTRIM DUETE}

Aprovada em: 14.12 .1995

Comissão Julgadora:

Prof. Dr. Eurípedes Malavolta

CENAIUSP

Prof. Dr. José Carlos Chitolina

ESALQ/USP

Prof. Dr. Moacyr de O. Camponês do Brasil Sobrinho

ESALQ/USP

Prof. Dr. Braz Vitor Defelipo

UFV

Prof. Dr. Leonardo Theodoro Bull

FCA/UNESP

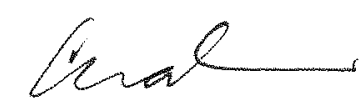

Prof.Dr. Eurípedes Malavolta Orientador 
Aos meus pais Antonio \& Amélia

que pelo despreendimento, força, diligência, sabedoria e sobretudo pelo imenso amor, propiciaram as condições básicas, para que eu seguisse este caminho.

A quem devo o que sou.

À memória do meu irmão: Luiz Alberto Aos meus irmãos:

Tânia, Rolemberg e Robson OFEREÇO

A minha esposa Renilda

por amor, amizade, lealdade...

sempre encorajadora e exigente do meu sucesso.

A meu filho Luiz Alberto Sobrinho

a maior felicidade e alegria de nossas vidas. 


\section{AGRADECIMENTOS}

À Deus, pela graça, pela presença e pela força constante nesta jornada.

* À Universidade Federal da Bahia -UFB ${ }^{a}$, pela oportunidade de ralização deste curso.

* À Universidade de São Paulo - USP, através da Escola Superior de Agricultura "Luiz de Queiroz", pelo curso proporcionado.

* Ao Professor Doutor Eurípedes Malavolta, pelas orientações seguras e pelos expressivos ensinamentos.

* Ao Prof. Dr. Takashi Muraoka pela amizade, bom convívio e pelas colaborações nas análises de solos.

* Ao Prof.Dr. José Carlos Chitolina, pela amizade, ajuda e contribuição.

* Ao Prof.Dr. Antonio Enedi Boaretto e Dra Maria Femanda Giné, pela colaboração nas análises de solo e planta, respectivamente.

* Aos Professores Dr. Braz Vitor Defelipo, Dr. Leonardo T. Bull e Dr. Moacyr de O. Camponês do Brasil Sobrinho, pelas contribuições.

* Ao Eng.Agr. Jairo Costa Barreto, Diretor Presidente da Empresa de Assessoria e Planejamento Agropecuário Ltda (EMAPA) pelo apoio na remessa dos solos.

* Aos Engs. Agrs. Valfredo Dourado, Sandra Maria Ferreira Amim e Elder Manoel de Moura Rocha, pesquisadores da EBDA, pelo apoio na coleta das amostras dos solos.

* Aos colegas Eduardo Jorge Maklouf Carvalho, lla Cardim Rêgo, Rivaldo Vital, Manoel Cravo, Raimundo N. Assis Jr. , José Raimundo Natividade Gama, Wilson Mozena Leandro e Maria do Rosário Lobato Rodrigues, pela amizade e convivio acadêmico.

* Aos funcionários do Centro de Energia Nuclear na Agricultura (CENA) Cleusa, Henriqueta, João Salvador, Marileuza, Roberto, Sandra Genaro, Sandra Teresa e Suzineide, pelos auxílios e colaborações.

* À Maria Aparecida Calegaro pela amizade, interesse e cuidado na digitação da tese.

* Ao casal Antonio e Iracema Nascimento, pela gentil acolhida em Piracicaba e pelo convivio agradável.

* À bibliotecária Marilia Ribeiro Garcia Henyei, pelo apoio.

* A todos que contribuiram, direta ou indiretamente na realização deste trabalho, expresso meus sinceros agradecimentos. 


\section{SUMÁRIO}

LISTA DE FIGURAS................................................................... ix

LISTA DE TABELAS ...................................................................

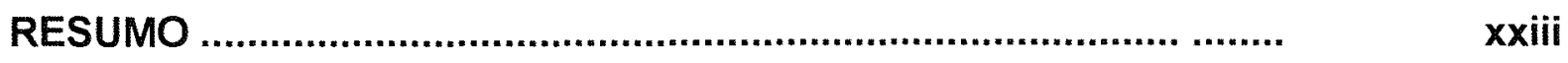

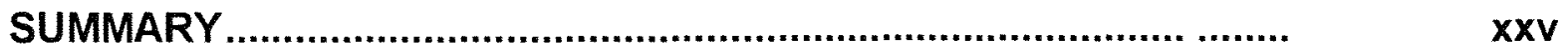

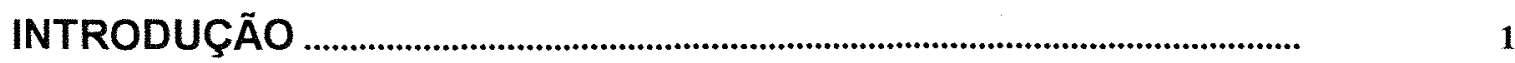

2. REVISÃO DE LITERATURA ....................................................... 3

2.1. Os Latossolos.............................................................................

2.2. Os Cambissolos ..............................................................................

2.3. Interação entre os Cátions Potássio, Cálcio e Magnésio.............. 5

2.4. Intensidade ou Potencial de Potássio ou Energia Livre de Troca 8

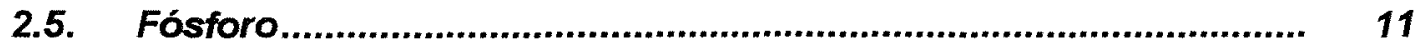

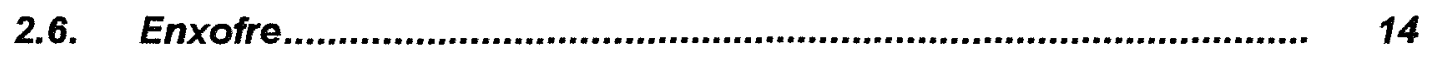

2.7. Boro

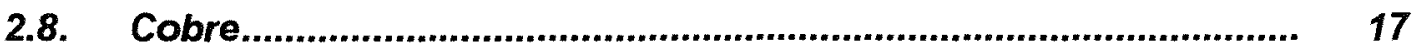

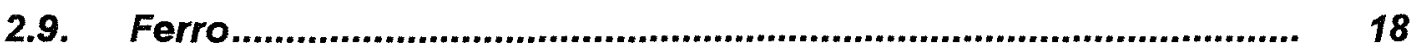

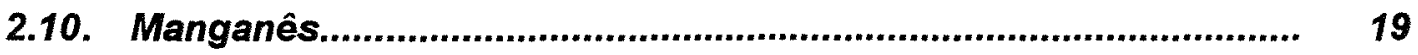

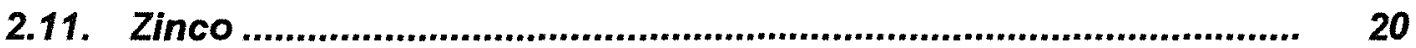


3. MATERIAL E MÉTODOS.

3.1. Localização dos Ensaios

3.2. Caracterizações Físicas, Mineralógicas e Químicas das Amostras.

3.2.1. Análise Granulométrica

3.2.2. Análise Mineralógica

3.2.3. Análise Química do Solo

3.3. Experimentos em Casa de Vegetação

3.3.1. Delineamento Experimental e Análise Estatística

3.3.1.2. Diagnose de P, S e Micronutrientes.

3.3.2. Instalação e Condução dos Experimentos

3.3.2.1.Estudo da Relação K/(Ca+Mg) .

3.3.2.2.Diagnose de P, S e Micronutrientes.

3.3.3. Análise Química dos Solos

3.3.3.1.Estudo da Relação K/(Ca+Mg)

3.3.3.2. Diagnose de $P$, S e Micronutrientes.

3.3.4. Análise Química do Material Vegetal. 
4. RESULTADOS E DISCUSSÃO

4.1. Características Fisicas, Mineralógicas e Químicas dos Solos.....

4.1.1. Análises Granulométricas

4.1.2. Análises Mineralógicas

4.1.3. Análises Químicas

4.2. Estudo da Relação $K /(\mathrm{Ca}+\mathrm{Mg})$ no Solo

4.2.1. Produção de Grãos e Matéria Seca, Teores e Conteúdos de K, Ca, Mg, nas folhas, e nos Grãos do Feijoeiro em Função das Relações $\mathrm{K} /(\mathrm{Ca}+\mathrm{Mg})$ Aplicadas nos Solos.

4.2.1.1.Produção de Grãos e Matéria Seca

4.2.1.2.Teores de K, Ca e Mg nas Folhas do Feijoeiro.

\subsubsection{Teores e Conteúdos de K, Ca e Mg nos Grãos do} Feijoeiro em Função das Relações $\mathrm{K} /(\mathrm{Ca}+\mathrm{Mg})$ Aplicadas nos Solos.

4.2.2. Potencial de $\mathrm{K}$ em Função das Relações $\mathrm{K} /(\mathrm{Ca}+\mathrm{Mg})$

Aplicadas nos Solos

4.2.3. Teores de K, Ca e Mg Trocáveis Recuperados Antes e Após o Cultivo dos Solos em Função das Relações $\mathrm{K} /(\mathrm{Ca}+\mathrm{Mg})$ Aplicadas nos Solos 
4.3. Diagnose por Subtração de Fósforo Enxofre e Micronutrientes.

4.3.1. Produção de Grãos e Matéria Seca

4.3.2. Teor e Conteúdo de Fósforo

4.3.3. Teor e Conteúdo de $\mathrm{K}$, Ca e $\mathrm{Mg}$

4.3.4. Teores e Conteúdos do Enxofre ..................................... 89

4.3.5. Teor e Conteúdo de Boro ................................................... 97

4.3.6. Teor e Conteúdo de Cobre ............................................... 97

4.3.7. Teor e Conteúdo de Ferro ................................................ 98

4.3.8. Teor e Conteúdo de Manganês ......................................... 98

4.3.9. Teor e Conteúdo de Zinco .............................................. 99

4.3.10. Valores de Macro e Micronutrientes Recuperados Antes e Após o Cultivo dos Solos em Função dos Tratamentos Aplicados 


\section{LISTA DE FIGURAS}

Figura

Página

Difratograma de raio $X$ da fração silte do Latossolo

Vermelho Amarelo

Difratograma de raio $X$ da fração silte do Latossolo

Amarelo

Difratograma de raio $X$ da fração silte do Cambissolo

Vértico

Difratograma de raio $\mathrm{X}$ da fração silte do Cambissolo

Latossólico.

Difratograma de raio $X$ da fração argila do latossolo

Vermelho Amarelo

Difratograma de raio $X$ da fração argila do Latossolo

Amarelo. 
Difratograma de raio $X$ da fração argila do cambissolo

Vértico

Difratograma de raio $X$ da fração do Cambissolo

Latossólico.

Teores de $\mathrm{K}$ nas folhas do feijoeiro (na floração), em função das relações $\mathrm{K} /(\mathrm{Ca}+\mathrm{Mg})$ aplicadas no Cambissolo Vértico

Teores de $\mathrm{K}$ nas folhas do feijoeiro (final do ciclo), em função das relações $\mathrm{K} /(\mathrm{Ca}+\mathrm{Mg})$ aplicadas no Cambissolo Vértico

Teores de $K$ nas folhas do feijoeiro, (na floração), em função das relações $\mathrm{K} /(\mathrm{Ca}+\mathrm{Mg})$ aplicadas no Cambissolo Latossólico.

Teores de $\mathrm{K}$ nas folhas do feijoeiro, (final do ciclo), em função das relações $\mathrm{K} /(\mathrm{Ca}+\mathrm{Mg})$ aplicadas no Cambissolo Latossólico. 
Teores de Ca nas folhas do feijoeiro, (na floração), em função das relações $\mathrm{K} /(\mathrm{Ca}+\mathrm{Mg})$ aplicadas no Latossolo Amarelo

Teores de Ca nas folhas do feijoeiro, (final do ciclo), em função das relações $\mathrm{K} /(\mathrm{Ca}+\mathrm{Mg})$ aplicadas no Latossolo Amarelo

Teores de Mg nas folhas do feijoeiro, (na floração), em função das relações $\mathrm{K} /(\mathrm{Ca}+\mathrm{Mg})$ aplicadas no Cambissolo Vértico. Teores de Mg nas folhas do feijoeiro, (final do ciclo), em função das relações $\mathrm{K} /(\mathrm{Ca}+\mathrm{Mg})$ aplicadas no Cambissolo Vértico

Teores de Ca nos grãos do feijoeiro, em função das relações $\mathrm{K} /(\mathrm{Ca}+\mathrm{Mg})$ aplicadas no Latossolo Amarelo

Quantidade de Ca nos grãos do feijoeiro, em função das relações $\mathrm{K} /(\mathrm{Ca}+\mathrm{Mg})$ aplicadas no Latossolo Amarelo 
Potencial de potássio (pK-0,5p (Ca+Mg)), antes e após o cultivo do solo em função das relações $\mathrm{K} /(\mathrm{Ca}+\mathrm{Mg})$, aplicadas no Latossolo Vermelho Amarelo

Energia livre de troca $\Delta \overline{\mathbf{G}}(1364 \log (\operatorname{aK} / \sqrt{a(C a+M g)})$

antes e após o cultivo do solo, em função das relações

$\mathrm{K} /(\mathrm{Ca}+\mathrm{Mg})$, aplicadas no Latossolo Vermelho Amarelo

Potencial de potássio (pK-0,5 p $(\mathrm{Ca}+\mathrm{Mg}))$, antes do cultivo do solo, em função das relações $\mathrm{K} /(\mathrm{Ca}+\mathrm{Mg})$, aplicadas no Latossolo Amarelo

Potencial de potássio (pK-0,5 p ( $\mathrm{Ca}+\mathrm{Mg})$ ), após o cultivo do solo, em função das relações $\mathrm{K} /(\mathrm{Ca}+\mathrm{Mg})$, aplicadas no Latossolo Amarelo

Energia livre de troca $\Delta \overline{\mathbf{G}}(1364 \log (\mathrm{AK} / \sqrt{a(C a+M g)})$ antes do cultivo do solo, em função das relações $\mathrm{K} /(\mathrm{Ca}+\mathrm{Mg})$, aplicadas no Latossolo Amarelo 
Energia livre de troca $\Delta \overline{\mathbf{G}}(1364 \log (\mathrm{aK} / \sqrt{a(C a+M g)})$

após o cultivo do solo em função das relações $\mathrm{K} /(\mathrm{Ca}+\mathrm{Mg})$,

aplicadas no Latossolo Amarelo

Potencial de potássio (pk-0,5 p ( $\mathrm{Ca}+\mathrm{Mg})$ ), antes do cultivo do solo, em função das relações $\mathrm{K} /(\mathrm{Ca}+\mathrm{Mg})$, aplicadas no Cambissolo Vértico

Potencial de potássio (pK-0,5p ( $\mathrm{Ca}+\mathrm{Mg})$ ), após o cultivo do solo, em função das relações $\mathrm{K} /(\mathrm{Ca}+\mathrm{Mg})$ aplicadas no Cambissolo Vértico

Energia livre de troca $\Delta \overline{\mathbf{G}}(1364 \log (\mathrm{aK} / \sqrt{a(C a+M g)})$ antes do cultivo do solo, em função das relações $\mathrm{K} /(\mathrm{Ca}+\mathrm{Mg})$, aplicadas no Cambissolo Vértico 
Potencial de potássio (pK-0,5p $(\mathrm{Ca}+\mathrm{Mg})$, antes do cultivo do solo, em função das relações $\mathrm{K} /(\mathrm{Ca}+\mathrm{Mg})$, aplicadas no Cambissolo Latossólico

Potencial de potássio ( $\mathrm{pK}-0,5$ p $(\mathrm{Ca}+\mathrm{Mg})$ ), após o cultivo do solo, em função das relações $\mathrm{K} /(\mathrm{Ca}+\mathrm{Mg})$, aplicadas no cambissolo Latossólico .

Energia livre de troca $\Delta \overline{\mathbf{G}}(1364 \log$ aK $/ \sqrt{a(C a+M g)})$ antes do cultivo do solo, em função das relações $\mathrm{K} /(\mathbf{C a}+\mathbf{M g})$, aplicadas no cambissolo latossólico

Energia livre de troca $\Delta \overline{\mathbf{G}}(1364 \log$ aK/ $\sqrt{a(C a+M g)})$

após o cultivo do solo, em função das relações

K/(Ca+Mg), aplicadas no Cambissolo Latossólico 


\section{LISTA DE TABELAS}

Tabela

Página

Valores médios de potássio, cálcio e magnésio (mmol $\left./ \mathrm{dm}^{3}\right)$, relações $\mathrm{Ca} / \mathrm{Mg}$ e $\mathrm{K} /(\mathrm{Ca}+\mathrm{Mg})$, percentagem de potássio, cálcio e magnésio na CTC dos solos estudados

Percentagens de saturação de potássio na CTC, níveis de potássio a ser atingidos $\left(\mathrm{mmol}_{\mathrm{d}} / \mathrm{dm}^{3}\right)$ e quantidades de potássio e magnésio adicionadas em função das relações

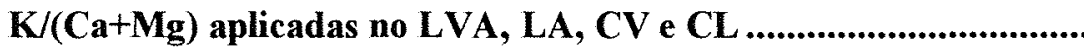

Doses de potássio e magnésio em $\mathrm{mmol}_{\mathrm{c}} / \mathrm{dm}^{3}$ e de $\mathrm{KCl}$ e $\mathrm{MgCl}_{2} \mathrm{em}$ g/vaso usadas na incubação do ensaio 
Valores médios de potássio, cálcio e magnésio $\left(\mathbf{m m o l} / \mathbf{d m}^{3}\right)$, relações $\mathrm{Ca} / \mathrm{Mg}$ e $\mathrm{K}(\mathrm{Ca}+\mathrm{Mg})$ atingidos para os solos LVA, LA, CV e CL

Composição mineralógica qualitativa das amostras dos LVA, LA, CV e CL estudados

Análise química de micronutrientes das amostras dos solos estudados

Valores médios de produção de grãos e acúmulo de matéria seca nas folhas, raízes, caule + ramos, vagens debulhadas e total (g/vaso), para cultura do feijoeiro, em função das relações $\mathrm{K} /(\mathrm{Ca}+\mathrm{Mg})$ aplicadas no $\mathrm{LVA}$, LA, CV e CL 
Teores médios de potássio, cálcio e magnésio $(\mathrm{g} / \mathrm{kg})$ nas

folhas do feijoeiro, na floração e no final do ciclo da cultura, em funçãio das relações $\mathrm{K} /(\mathrm{Ca}+\mathrm{Mg})$, aplicadas no no LVA, LA, CV e CI

Valores médios de potássio, cálcio e magnésio em teor (g/kg) e conteúdo (mg/vaso) nos grãos do feijoeiro, em função das relações $\mathrm{K} /(\mathrm{Ca}+\mathrm{Mg})$ aplicadas no $\mathrm{LVA}$, LA, CV e CL Potencial de potássio (pk-0,5p $(\mathrm{Ca}+\mathrm{Mg})$ ), e energia livre de troca $\Delta \overline{\mathbf{G}}(1364 \log (\mathrm{ak} / \sqrt{a(C a+M g)})$ antes e após o cultivo dos solos, em função das relações $\mathrm{K} /(\mathrm{Ca}+\mathrm{Mg})$, aplicadas no LVA, LA, CV e CL ......................................................

14 Valores médios de potássio, cálcio e magnésio trocáveis $\left(\operatorname{mmol}_{\mathrm{d}} / \mathrm{dm}^{3}\right)$, recuperados antes e após o cultivo dos solos, em função das relações $\mathrm{K} /(\mathrm{Ca}+\mathrm{Mg})$ aplicadas no $\mathrm{LVA}$, LA, CV e CL 
Valores médios de produção de grãos e acúmulo de matéria seca nas folhas, raízes, caule + ramos, vagens debulhadas e total (g/vaso) para cultura do feijoeiro, em função dos tratamentos aplicados no LVA e LA

Valores médios de produção de grãos e acúmulo de matéria seca nas folhas, raízes, caule + ramos, vagens debulhadas e total (g/vaso), para cultura do feijoeiro, em função dos tratamentos aplicados no CV e CL

Produção relativa de grãos em função dos tratamentos aplicados no LVA, LA , CV e CL

Teores médios de fósforo, potássio, cálcio, magnésio e enxofre ( $\mathrm{g} / \mathrm{kg}$ ), nas folhas do feijoeiro (na floração), em função dos tratamentos aplicados no LVA e LA. Teores médios de fósforo, potássio, cálcio, magnésio e enxofre $(g / k g)$, nas folhas do feijoeiro (na floração), em função dos tratamentos aplicados no CV e CL ................................ 
Teores médios de fósforo, potássio, cálcio, magnésio e enxofre $(g / \mathrm{kg})$, nos grãos do feijoeiro em função dos tratamentos aplicados noLVA e LA.

Teores médios de fósforo, potássio, cálcio, magnésio e enxofre $(\mathrm{g} / \mathrm{kg})$, nos grãos do feijoeiro em função dos tratamentos aplicados no CV e CL

22 Quantidade de fósforo, potássio, cálcio, magnésio e enxofre (mg/vaso) exportados nos grãos pela cultura do feijoeiro em função dos tratamentos aplicados no LVA e LA

Quantidade de fósforo, potássio, cálcio, magnésio e enxofre (mg/vaso) exportados nos grãos pela cultura do feijoeiro em função dos tratamentos aplicados no CV e CL ..............

24 Teores médios de boro, cobre, ferro, manganês e zinco (mg/kg), nas folhas do feijoeiro (na floração), em função dos tratamentos aplicados no LVA e LA ....................................... 
Teores médios de boro, cobre, ferro, manganês e zinco

(mg/kg), nas folhas do feijoeiro (na floração), em função

dos tratamentos aplicados no CV e CL.......................................... 101

Teores médios de boro, cobre, ferro, manganês e zinco

(mg/kg), nos grãos do feijoeiro, em função dos

tratamentos aplicados no LVA e LA..............................................

Teores médios de boro, cobre, ferro, manganês e zinco

(mg/kg), nos grãos do feijoeiro, em função dos

tratamentos aplicados no CV e CL

103

Quantidade de boro, cobre, ferro, manganês e zinco ( $\mu \mathrm{g} / \mathrm{vaso})$, exportadas nos grãos pela cultura do feijoeiro, em função dos tratamentos aplicados no LVA e LA ..........................

Quantidade de boro, cobre, ferro, manganês e zinco ( $\mu$ g/vaso), exportadas nos grãos pela cultura do feijoeiro, em função dos tratamentos aplicados no CV e CL 
Valores médios de fósforo disponíveis $\left(\mathrm{mg} / \mathrm{dm}^{3}\right)$, potássio,

cálcio e magnésio trocáveis $\left(\mathrm{mmol}_{\mathrm{d}} / \mathrm{dm}^{3}\right)$, recuperados

antes do cultivo dos solos, em função dos tratamentos

aplicados no LVA, LA e CL

Valores médios de fósforo disponíveis, enxofre, boro, cobre, ferro, manganês e zinco $\left(\mathrm{mg} / \mathrm{dm}^{3}\right)$ e potássio, cálcio e magnésio trocáveis $\left(\mathrm{mmol}_{\mathbf{d}} / \mathrm{dm}^{3}\right)$, antes do cultivo do LVA, LA, CV e CL.

Valores médios de fósforo e enxofre disponiveis $\left(\mathrm{mg} / \mathrm{dm}^{3}\right)$, potássio, cálcio e magnésio trocáveis $\left(\mathrm{mmol}_{\mathrm{d}} \mathrm{dm}^{3}\right)$, recuperados após o cultivo dos solos em função dos tratamentos aplicados no LVA e LA..................................................

Valores médios de fósforo e enxofre disponíveis $\left(\mathrm{mg} / \mathrm{dm}^{3}\right)$, potássio, cálcio e magnésio trocáveis $\left(\mathrm{mmol}_{\mathrm{d}} / \mathbf{d m}^{3}\right)$, recuperados após o cultivo dos solos em função dos tratamentos aplicados no $\mathrm{CV}$ e $\mathrm{CL}$ 
Valores médios de boro, cobre, ferro, manganês e zinco

$\left(\mathbf{m g} / \mathbf{d m}^{3}\right)$, recuperados após o cultivo dos solos, em função

dos tratamentos aplicados no CV e CL............................................

Valores médios de boro, cobre, ferro, manganês e zinco

$\left(\mathbf{m g} / \mathbf{d m}^{3}\right)$, recuperados após o cultivo dos solos, em função

dos tratamentos aplicados no LVA e LA. 


\title{
ESTUDO DA RELAÇÃO KI(Ca+Mg) E DIAGNOSE POR SUBTRAÇÃO DE P, S E MICRONUTRIENTES EM SOLOS CALCÁRIOS DA MICRORREGIÃO DE IRECÊ-BA
}

\author{
Autor: Washington Luiz Cotrim Duete \\ Orientador: Prof. Dr. Eurípedes Malavolta
}

RESUMO

O presente trabalho teve como propósito caracterizar fisica, quimica e mineralogicamente quatro solos calcários da microrregião de Irecê-Bahia: um Latossolo Vermelho Amarelo (LVA), um Latossolo Amarelo (LA), um Cambissolo Vértico (CV) e um Latossolo Cambissólico (CL); como também, estudar preliminarmente a influência de diferentes relações $\mathrm{K}(\mathrm{Ca}+\mathrm{Mg})$ do solo e a dignose por subtração de fósforo, enxofre e micronutrientes, na produção de grãos, matéria seca de folhas, raizes, caule +ramos, vagem e total, e na absorção desses nutrientes por planta de feijão (Phaseolus vulgaris L.); verificar a influência do potencial de potássio $(\mathrm{pK}-0,5 \mathrm{p}(\mathrm{Ca}+\mathrm{Mg})$ do solo na absorção de potássio, cálcio e magnésio pelo feijoeiro; encontrar uma relação nutricional entre os niveis de $\mathrm{Ke}$ de $\mathrm{Ca}+\mathrm{Mg}$ do solo para o melhor desenvolvimento da cultura; investigar se o $\mathrm{P}, \mathrm{S}$, $\mathrm{B}, \mathrm{Cu}, \mathrm{Fe}, \mathrm{Mn}$ e $\mathrm{Zn}$ são limitantes ao crescimento do mesmo e medir essas limitações verificando possiveis interações nutricionais no sistema solo-feijoeiro.

$O$ estudo constituiu na instalação de dois experimentos em casa de vegetação no Centro de Energia Nuclear na Agricultura (CENA), em vaso com capacidade de $1,5 \mathrm{dm}^{3}$, utilizando amostras superficiais de $0-20 \mathrm{~cm}$ dos quatro solos citados.

Os experimentos foram conduzidos obedecendo-se um delineamento inteiramente casualizado. No estudo da relação $\mathrm{K} /(\mathrm{Ca}+\mathrm{Mg})$ envolveu-se oito relações com três repetições para o LA, CV e CL e apenas quatro 
relações com seis repetições para o LVA. Para que estas relações fossem atingidas, os solos receberam quantidades determinadas de cloreto de potássio e cloreto de magnésio, todas drogas pró-análise, e deixados em incubação por um período de 30 dias, mantendo-se a umidade em torno de $80 \%$ da capacidade de campo. Na diagnose por subtração utilizaram-se nove tratamentos com três repetições, sendo o LVA incubado com cloreto de potássio, o LA e CL com cloreto de potássio e cloreto de magnésio e para o $\mathrm{CV}$ não utilizaram-se nutrientes na incubação. Após o período de incubação, foram coletada amostras de terra para análise química e, em seguida, adubados segundo MALAVOLTA \& MURAOKA (1985), observando na diagnose por subtração que a omissão de um nutriente implicou na completa ausência deste na adubação de plantio. Quarenta dias após a emergência, foi realizada a colheita, os grãos e a parte aérea foram secos, pesados e, juntamente com as amostras de solos, foram submetidos à análise química. Com os valores de produção de matéria seca, dos nutrientes recuperados do solo e dos nutrientes absorvidos, em função dos tratamentos aplicados no solo, realizaram-se análise de variância, testes de médias e estabeleceram-se equações de regressão.

A produção do feijoeiro, tanto em grãos como em matéria seca de suas partes, não foi influenciada pelas relações $K /(\mathrm{Ca}+\mathrm{Mg})$, bem como, pela mudança da relação $\mathrm{Ca} / \mathrm{Mg}$ do solo, em ambos os solos.

Os valores de potencial de potássio e energia livre de troca no solo $(\Delta \bar{G})$, não se enquadram aos limites de equilíbrio adequado entre cálcio e potássio e aos de deficiência de qualquer destes nutrientes sugerido pela literatura, dando a entender serem outros valores para solos calcários.

As equações de regressões entre os valores de $\mathrm{K} /(\mathrm{Ca}+\mathrm{Mg})$ no solo e os dados de potencial de potássio e $\Delta \bar{G}$, apresentaram antes do cultivo modelos altamente significativos, alcançando coeficientes de determinação $\left(R^{2}\right)$ alto. Todavia, após o cultivo obtiveram-se correlações não significativas.

O crescimento e a produção de grãos do feijoeiro, foram afetados no LVA pela omissão de $P, S$, Cu e Fe. No LA pela omissão de $P$ e $S$. Já no CV pela omissão de $P, S, C u, M n$ e Zn. E no CL pela omissão de P, S, Mn e Zn. 


\title{
STUDY OF THE KICa+Mg RATIO AND OF DIAGNOSIS BY SUBTRACTION OF P, S AND MICRONUTRIENTS IN CALCAREOUS SOILS OF THE IRECÊ, BA MICRO REGION
}

\author{
Author: Washington Luiz Cotrim Duete \\ Adviser: Prof. Dr. Euripedes Malavolta
}

\section{SUMMARY}

The present work had the following objectives: to characterize from the physical, chemical and mineralogical points of view four calcareous soils from the Irecê, BA, microregion, namely a Red Yellow Latosol (LVA), a Yellow Latosol (LA), a Vertic Cambisol (CV) and a Cambic Latosol (CL); to evaluate the effects of the $\mathrm{K} / \mathrm{Ca}+\mathrm{Mg}$ ratios on growth yield, and mineral composition of the bean (Phaseolus vulgaris L.) plant under greenhouse conditions; to find out the effect of the omission of $\mathrm{P}, \mathrm{S}, \mathrm{B}, \mathrm{Cu}, \mathrm{Fe}, \mathrm{Mn}$ and $\mathrm{Zn}$ on the production and mineral composition of the bean plant, also under greenhouse conditions; to assess the influence of the $\mathrm{K}$ potential on the uptake of potassium by the bean plants.

In the study of the $\mathrm{K} / \mathrm{Ca}+\mathrm{Mg}$ ratios eight ratios with three replicates were established for the LA, CV and CL, and only four ratios with six replicates in the case of LVA. In order to reach the desired ratios the soils were treated with the chlorides of potassium and magnesium and incubated with these soils during 30 days under $80 \%$ of the field capacity. A completely randomized design was used. In the experiment using the diagnosis by subtraction technique there were nine treatments with three replicates; the LVA was incubated with $\mathrm{KCl}$, the LA and the $\mathrm{CL}$ with both $\mathrm{K}$ and $\mathrm{Mg}$ chlorides, and no additions in the incubation of $\mathrm{CV}$. After the incubation period soil samples were collected for analyses and the adequate treatments were applied. Growth, yield date and figures for mineral composition were subject of statistical analyses, variance and regression whenever applicable.

Main conclusions were as follows: bean yield was not affected neither by the $\mathrm{K} / \mathrm{Ca}+\mathrm{Mg}$ nor $\mathrm{Ca} / \mathrm{Mg}$ in the soil; the values for potassium potential 
and free energy of $\mathrm{K}$ do not agree with those found in the literature which suggests that in the case of calcareous soils they do not fit; coefficients of determination (R2) highly significant were obtained in the determinations of $\mathrm{K} /(\mathrm{Ca}+\mathrm{Mg}) ; \mathrm{K}$ potencial and $\Delta G$ before growing the bean plants. After harvest, however, correlations were not significant bean production was affected by the lack of $P$ and $S$ in the LVA; omission of $P$ and $S$ induced yield in the LA; $P, S, C u, M n$ and $Z n$ were limiting in the $C V$; in the case of $C L$ the elements $P, S$ and $M n$ caused inductions in yield. 


\section{INTRODUÇÃO}

O feijão é um dos mais importantes grãos para alimentação do povo brasileiro, pois constitui a principal fonte de proteina vegetal, em média, de $24 \%$ (EMPRESA BRASILEIRA DE PESQUISA AGROPECUÁRIA, 1981), podendo substituir, parcialmente, a proteína das carnes, motivo pelo qual o feijoeiro é cultivado em todo o território nacional.

É considerada uma cultura de alto risco, sensivel às adversidades climáticas que, eventualmente, ocorrem no período de seu desenvolvimento e ao ataque de pragas e doenças. É uma cultura que recebe poucos incentivos e, em consequência, pequenas quantidades de corretivos e fertilizantes são aplicados, quando comparadas com as culturas de expressão econômica, pois os pequenos agricultores, que são os maiores responsáveis pela produção brasileira de feijão, pouco se beneficiam desses incentivos, por falta de maior representação frente a estabelecimentos de crédito, assistência técnica, comercialização e seguro agrícola (GUAZZELLI, 1983).

A microrregião de Irecê-BA, como grande parte do nordeste brasileiro, do ponto de vista fisiográfico, caracteriza-se pela presença de um clima tipo semi-árido com precipitaçōes pluviométricas irregulares, portanto, secas periódicas, atuando sobre um mosaico de solos extremamente variado, alguns com excelente fertilidade natural (Cambissolos e Latossolos do platô de Irecê), outros de difícil manejo, como os solos rasos e pedregosos. O relevo também varia bastante, assim como a vegetação, podendo, entretanto, observar-se uma certa relação entre as variáveis naturais (solo, clima, relevo, vegetação), na composição da paisagem.

A região é bastante conhecida pelo potencial agrícola e se caracteriza por uma alta produção de feijão, abastecendo inclusive o mercado nacional, nos anos considerados climaticamente normais. Essa alta produção é 
alternada por ano de frustração agrícola, quando as condições climáticas não correspondem à expectativa, gerando uma instabilidade na produção, com reflexos sociais e economicos os mais diversos.

A microrregião de Irecê-BA, está situada na MRH-135, Chapada Diamantina Setentrional, no centro do Estado da Bahia, e é responsável aproximadamente por $50 \%$ da área colhida de feijão em todo o Estado. Contudo, os rendimentos atingidos são muito baixos e vem caindo com o decorrer dos anos, à despeito do aumento da área colhida. Como exemplo, nos anos 89, 90 e 91 obteve-se em área colhida de $6.176,8.382$ e 8.339 ha produções de $1.668,4.191$ e $1.834 \mathrm{t}$, com um rendimento médio de 270,500 e $220 \mathrm{~kg} /$ ha respectivamente (EMPRESA DE ASSISTÊNCIA TÉCNICA E EXTENSÃO RURAL DA BAHIA, 1985).

Observando as análises químicas dos perfis de solos da região, supõe-se que, quanto à química e fertilidade do solo, o desequilibrio entre os cátions ( $\mathrm{Ca}, \mathrm{Mg}$ e $\mathrm{K}$ ), o baixo teor de fósforo e enxofre em alguns solos e possiveis problemas com micronutrientes, serem os responsáveis pelos baixos rendimentos atingidos. Sob tais condições, o presente trabalho foi desenvolvido, com os objetivos de:

1. Estudar a influência de diferentes relações $\mathrm{K} /(\mathrm{Ca}+\mathrm{Mg})$ do solo na produção de grãos, matéria seca e na absorção de potássio, cálcio e magnésio pelo feijoeiro.

2. Observar a influência do potencial de potássio do solo na produção de grãos, matéria seca e na absorção de potássio, cálcio e magnésio pelo feijoeiro.

3. Encontrar uma relação nutricional entre os níveis de potássio e os níveis de cálcio + magnésio do solo para o melhor desenvolvimento do feijoeiro.

4. Determinar se $P, S, B, C u, F e, M n$ e $\mathrm{Zn}$ são limitantes ao crescimento do feijoeiro. Medir essas limitações e verificar possiveis interações nutricionais no sistema solo-feijoeiro. 


\section{REVISÃO DE LITERATURA}

A microrregião de Irecê, situada na $\mathrm{MRH}-135$, Chapada Diamantina Setentrional, no centro do Estado da Bahia, do ponto de vista topográfico é uma chapada irregular, cujas altitudes variam de 600 a $800 \mathrm{~m}$, entre as coordenadas $41^{\circ} 00^{\prime}$ e $42^{\circ} 00^{\prime}$ de longitude oeste e $11^{\circ} 00^{\prime}$ e $12^{\circ} 00^{\prime}$ de longitude sul. É uma área de ocorrência dos calcários, dolomitos e ardósias que compõem o Grupo Bambuí. No topo da chapada, existem apenas elevações com afloramentos de calcários truncados exibindo lineações. Nos locais onde o calcário aflora com mergulho subvertical, finamente estratificado, as alterações apresentam-se espessas, acinzentadas e esbranquiçadas, tendo localmente crostas secundárias ou mesmo linhas de concreções de carbonato de cálcio, sendo algumas silinificadas no topo. Encontram-se ai solos do tipo Latossolos e Cambissolos (EMPRESA DE ASSISTÊNCIA TÉCNICA E EXTENSÃO RURAL DA BAHIA, 1985).

\subsection{Os Latossolos}

Estes solos formam os grandes chapadões, com relevo suave, mas, em geral, com grandes problemas de fertilidade. Ocorrem também em áreas acidentadas, mas com poucos aflomeramentos de rochas (RESENDE et al., 1988).

$\mathrm{O}$ teor de argila pode variar bastante nestes solos, o que possibilita a sua diferenciação textural (fases) em textura média, com teor de argila no horizonte $B$ variando de 15 a $35 \%$, textura argilosa variando de 35 a $60 \%$, e muito argilosa maior que $60 \%$.

Apresentam baixa relação molecular $\mathrm{SiO}_{2} / \mathrm{Al}_{2} \mathrm{O}_{3}$ (Ki) na fração argila, normalmente inferior a 2,0 , sendo raros os casos em que atinge 2,2 , indicando alto 
grau de intemperização da massa do solo; baixa capacidade de permuta de cátions (valor $T$ ) da fração argila, em decorrência do material do solo ser constituido por sesquióxidos, minerais de argila 1:1 (grupo da caulinita), quartzo e outros minerais altamente resistentes ao intemperismo; minerais primários facilmente decomponiveis ausentes ou mesmo presentes em quantidades muito pequena.

Por se encontrar nas áreas de ocorrências dos calcários (material de origem rico em bases), sob clima do tipo semi-árido, possuem saturação de bases maior que $50 \%$ (EMPRESA BRASILEIRA DE PESQUISA AGROPECUÁRIA, 1988).

\subsection{Os Cambissolos}

Esta unidade compreende solos com B incipiente ou câmbico, não hidromórficos, com pequena diferenciação de textura do horizonte $A$ para $\circ B$. Não possuem acumulação de argila iluvial que permita classifica-los como solos com horizonte $B$ textural. Muitas vezes, apresentam características morfológicas e mesmo químicas similares às dos Latossolos, porém, deles diferenciam-se por apresentarem altos teores de silte em relação à argila e/ou maior proporção de minerais primários facilmente intemperizáveis (RESENDE et al., 1988).

Possuem relação molecular $\mathrm{Ki}\left(\mathrm{SiO}_{2} / \mathrm{Al}_{2} \mathrm{O}_{3}\right)$ e relação silte/argila com valores médios ou altos em alguns solos e baixos em outros; quando desenvolvidos de rochas carbonatadas podem apresentar carbonatos livres, desde a superfície dos solos, ou acumulados nos horizontes subsuperficiais.

Estes solos no estado da Bahia, apresentam sequência de horizontes $A,(B), C$ e $R$, com horizontes $A$ fraco, moderado e até chernozêmico; textura média e argilosa; rasos e profundos; moderadamente e bem drenados, ocorrendo, no entanto, perfis imperfeitamente drenados.

A maior parte dos cambissolos compreende solos eutróficos (saturação de bases superior a 50\%), principalmente na zona semi-árida (Irecê), ocorrendo também solos distróficos (saturação de bases inferior a $50 \%$ ), principalmente na zona cacaueira (sul da Bahia) (EMPRESA BRASILEIRA DE PESQUISA AGROPECUÁRIA, 1988). 
Estes cambissolos baianos, da chapada do Apode (RN e CE) e do Norte de Minas Gerais, são originados de rochas calcárias, possuem relevo plano e apresentam certa deficiência de oxigênio, além de apresentarem altos teores de manganês.

Apesar de serem eutróficos, os teores de fósforo são baixos. Devido ao relevo plano e à baixa permeabilidade do material em função da presença de argila de atividade alta, estes sistemas são considerados conservadores de nutrientes (ERNESTO SOBRINHO, 1980).

\subsection{Interação entre os Cátions Potássio, Cálcio e Magnésio}

Um dos primeiros pesquisadores a observar uma interação negativa entre os cátions, PIERRE \& BOWER (1943), que atribuiu as baixas produções de trigo mourisco ao decréscimo na absorção de potássio em decorrência da aplicação de doses elevadas de calcário; segundo o autor, o cálcio apresentava um efeito antagônico sobre a absorção de potássio, chamando a atenção para a importância do equilíbrio cálcio-potássio na nutrição das plantas. A partir da formulação da "Lei da potassa-calcário" por Ehremberg em 1919, foi estimulado o estudo sobre as interações entre o K, Ca e Mg.

DUETE (1993) trabalhando com solos do Recôncavo da Bahia, observou que o Latossolo Vermelho Amarelo e Podzólico Vermelho Amarelo com teores de potássio, cálcio e magnésio trocáveis (meq/100 $\left.\mathrm{cm}^{3}\right)$ de 0,$15 ; 0,7 ; 0,2$ e 0,$16 ; 2,3 ; 4,8$ respectivamente, não responderam ao potássio aplicado na produção de matéria seca do feijoeiro. Todavia, o Brunizem Avermelhado com teores de potássio, cálcio e magnésio trocáveis $\left(\mathrm{meq} / 100 \mathrm{~cm}^{3}\right)$ de 0,$23 ; 14,9 ; 9,1$ respectivamente, considerados satisfatórios, responderam a aplicação de potássio. Segundo o autor apesar do alto teor de potássio encontrado neste solo, é provável que a resposta encontrada tenha sido devido a relação entre o potássio e os outros cátions $\left(\mathrm{Ca}^{2+} e \mathrm{Mg}^{2+}\right.$, em particular).

Em razão dos teores de potássio trocável do solo não explicar completamente o que está ocorrendo, é que nos últimos anos, a maioria dos trabalhos nesta linha é baseado na lei da relação de Schofield que governa o equilíbrio de cátions na solução do solo. 
Segundo MALAVOLTA (1976), o antagonismo iônico entre o potássio, cálcio e magnésio, é antes de tudo, resultado de uma competição iônica na solução do solo. Todavia, para FASSBENDER (1972), independentemente das bases trocáveis, devem-se levar em consideração o grau de saturação do complexo de troca, os tipos de coloides, a natureza dos ions complementares adsorvidos e as relações entre os íons nutrientes do solo, visto que esses fatores fornecem informações da capacidade do solo em nutrir as plantas.

MEDVEDEVA (1968), PATHAK \& KABRA (1972) e SOARES (1975) encontraram em suas pesquisas, evidências claras que 0 antagonismo entre potássio-cálcio é mais intenso que a ação antagônica entre potássio-magnésio. Estas conclusões tem apoio nos estudos de ALBAREDA (1958) que acredita ser a capacidade de penetração dos cátions nas raízes, as quais seguem a relação $\mathrm{K}>\mathrm{Na}>\mathrm{Mg}>\mathrm{Ca}$, a razão do maior antagonismo entre os cátions potássio-cálcio do que entre potássio-magnésio. Pois, a combinação de dois ions deve alcançar uma ação antagônica, tanto maior quanto mais separado estiverem entre si.

Vale ressaltar que, segundo CORDEIRO (1978), tanto o Ca como o Mg podem deprimir a absorção de $K$, como este também pode deprimir a absorção dos outros dois cátions pelas plantas. Também sob certas condições, o $\mathrm{Ca}$ e o Mg podem, por sua vez, estimular a absorção de K.

SOARES et al. (1983) chama atenção para o efeito estimulante do cálcio sobre a absorção de potássio, que é observado quando o cálcio está em baixas concentrações, todavia, aumentando a concentração do cálcio, o efeito estimulante diminui até ocorrer antagonismo entre esses cátions, passando ocorrer redução na absorção de potássio pelas plantas. Resultados semelhantes foram obtidos por SANCHES CONDE (1980) estudando as relações $\mathrm{K} / \mathrm{Ca}(1 / 1 ; 1 / 2 ; 1 / 4$; $1 / 6 ; 1 / 8)$ com alface em solução nutritiva.

Da mesma forma altas concentrações de potássio reduziram a absorção de cálcio e magnésio para as culturas de aveia, feijão e girassol (BRADAWY \& BUSSLER, 1968; PANDEi, 1972).

Também redução significativa na concentração de $\mathrm{Ca}$ e $\mathrm{K}$ foi observada por KEY \& KURTZ (1960) em plantas de soja proporcionais ao aumento na absorção de $\mathrm{Mg}$.

Por outro lado OMAR \& KOBBIA (1966), trabalhando com concentrações diferentes de potássio e magnésio na cultura de alfafa em solução 
nutritiva, observaram que a absorção de magnésio foi reduzida quando se aumentava as concentrações de potássio, por outro lado a absorção de potássio pouco foi afetada pela presença do magnésio.

BULL (1986) estudando a produção de matéria seca por gramínea e leguminosa forrageira em função das relações $\mathrm{K} /(\mathrm{Ca}+\mathrm{Mg})$ no solo, observou que tanto a graminea como a leguminosa apresentaram aumentos nos valores da relação $\mathrm{K} /(\mathrm{Ca}+\mathrm{Mg})$ na matéria seca, proporcionais à elevação dessas relações em ambos os solos, todavia, o aumento na absorção de potássio em função da elevação nas relações $\mathrm{K} /(\mathrm{Ca}+\mathrm{Mg})$ nos solos, promoveram decréscimos proporcionais na absorção de $\mathrm{Ca}+\mathrm{Mg}$ em todas as culturas. Segundo o autor a leguminosa cultivada isoladamente apresentou decréscimo na produção de matéria seca apenas na maior relação $\mathrm{K} /(\mathrm{Ca}+\mathrm{Mg})$ de cada solo, sugerindo que a relação entre $1 / 25-1 / 20$ são as mais apropriadas para o cultivo isolado da leguminosa estudada.

Para SOARES et al. (1988) as relações Ca:Mg:K de 12:3:1 com saturação em bases de $80 \%$ promoveram as maiores produções de grãos de trigo por vaso, no entanto a melhor saturação de potássio no complexo de troca do solo foi de $5 \%$.

Para WIKLANDER (1964), um solo ideal para as culturas teria $65 \%$ do complexo de troca saturado com $\mathrm{Ca}^{2+}, 10$ a $15 \%$ com $\mathrm{Mg}^{2+}$ e $5 \%$ com $\mathrm{K}^{+}$.

Segundo BOYER (1971), nos solos relativamente bem dotados em bases, carências de $\mathrm{K}$ pode aparecer com o teor de $\mathrm{K}$ inferior a $2 \%$ da soma das

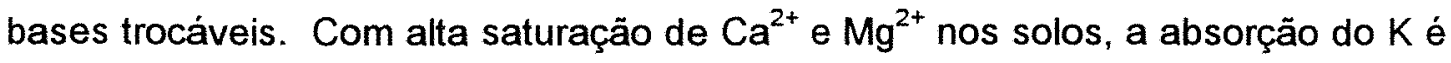
limitada e pode, até mesmo, acarretar deficiências (YORK et al., 1954; EVANS, 1955; MOURA FILHO, 1965).

LAROCHE (1966), afirma que as relações $\mathrm{Ca}^{2+} / \mathrm{Mg}^{2+}, \mathrm{Mg}^{2+} / \mathrm{K}^{+} \mathrm{e}$ $\left(\mathrm{Ca}^{2+}+\mathrm{Mg}^{2+}\right) / \mathrm{K}^{+}$ideais para o cacaueiro devem ser respectivamente 4,0;8,0 e 40,0. Também estudando os efeitos dos equilibrios entre $\mathrm{Ca}, \mathrm{Mg}$ e $\mathrm{K}$ no crescimento do cacaueiro, MORAIS \& CABALA (1971) concluiram que os rendimentos da matéria seca das plântulas de cacau estão mais bem relacionados com os valores da relação $(\mathrm{Ca}+\mathrm{Mg}) / \mathrm{K}$ que com a relação $\mathrm{Mg} / \mathrm{K}$.

Para BRICENO \& CARVAJAL (1973), quando a relação $(\mathrm{Ca}+\mathrm{Mg}) / \mathrm{K}$ do solo for maior que 10 , tal relação deve ser considerada como valor baixo para o potássio. 
Estudando o efeito da adubação potássica no algodoeiro, FUZZATO \& FERRAZ (1967) verificaram que a relação entre os teores trocáveis de Ca e K no solo mostrou-se como principal fator para explicar os efeitos provocados pela adubação potássica. Para valores de $\mathrm{Ca}^{2+} / \mathrm{K}^{+}$acima de 20 , houve aumentos consideráveis na produção em decorrência da aplicação de potássio e estes aumentos foram tanto maiores quanto maior o valor dessa relação, por outro lado, valores da relação $\mathrm{Ca}^{2+} / \mathrm{K}^{+}$abaixo de dez estavam associados a respostas insignificantes ou frequentemente negativas da adubação potássica.

BOYER (1971) relatou que, se um solo contém muito $\mathrm{K}$ e pouco $\mathrm{Mg}$, as plantas absorvem muito $\mathrm{K}$ e pouco $\mathrm{Mg}$. De certo modo, acontece a mesma coisa com a soma de $\mathrm{Ca}+\mathrm{Mg}$. Segundo esse autor, as relações $\mathrm{Mg} / \mathrm{K}$ e $\mathrm{Ca}+\mathrm{Mg} / \mathrm{K}$ não foram, infelizmente, objeto de estudos sistemáticos; o problema é complicado pelo fato de não serem essas relações as mesmas para todas as plantas, podendo um fornecimento de fertilizantes desiquilibrar as relações.

\subsection{Intensidade ou Potencial de Potássio ou Energia Livre de Troca}

A quantidade de potássio disponivel no solo, indica quanto potássio pode ser absorvido e até onde é possivel restaurar o reservatório da solução do solo diminuido pelo poder de extração das plantas, elevando-o a um nível satisfatório (MALAVOLTA, 1976).

Segundo SOARES (1978), tem sido sugerido o uso da relação entre as atividades do potássio para a do cálcio ou do cálcio + magnésio como um parâmetro de intensidade em lugar da atividade absoluta de potássio na solução do solo, isto porque o cálcio e o magnésio são os dois ions contrários mais importantes no processo de troca e na absorção do potássio.

$\mathrm{O}$ relacionamento entre os cátions potássio, cálcio e magnésio $\mathrm{e}$ suas absorções pelas plantas, segundo TISDALE \& NELSON (1975) envolve o fenômeno conhecido como "efeito do ion complementar", que é definido como a influência de um ion adsorvido sobre a liberação, para a solução do solo, de um outro a partir da superfície trocadora.

O conceito de potencial de potássio-cálcio, baseado em considerações dinâmicas, introduzidas por WOODRUFF (1955b), è definido como 
uma relação entre as atividades do ion potássio e do ion cálcio de uma solução do solo em equilibrio com a fase sólida, obtida com uma solução de $0,01 \mathrm{M}$ de cloreto de cálcio. E isto sugeriu, que a relação entre as atividades representava a energia livre de troca de cálcio pelo potássio, caracterizando o estado do potássio no solo, desde que o cálcio fosse o ion trocável dominante e o potássio de troca, a fonte principal desse elemento.

A expressão que calcula a energia livre de troca, é representada pela seguinte fórmula:

$$
\Delta \bar{G}=R T \ln a K / \sqrt{a C a}
$$

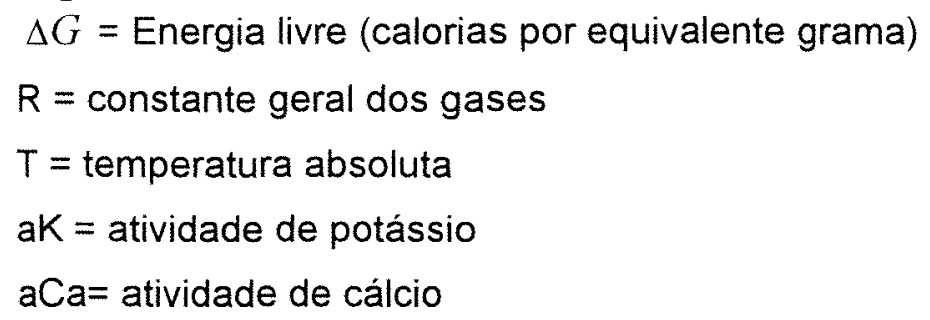

Segundo GETHING (1962), para fins práticos o magnésio também deve ser considerado na relação.

$$
\Delta \bar{G}=R T \ln (a K / \sqrt{a(C a+M g)}
$$

Utilizando-se o logaritmo decimal tem-se:

$$
\Delta \bar{G}=1364 \log (a K / \sqrt{a(C a+M g)}
$$

Sendo p o logaritmo do inverso da atividade de potássio, de cálcio e de magnésio.

$$
\Delta \bar{G}=1364[\mathrm{pK}-1 / 2 \mathrm{p}(\mathrm{Ca}+\mathrm{Mg})]
$$


A energia livre de um nutriente no solo segundo CHITOLINA ${ }^{1}$, determina a quantidade de trabalho que uma planta tem que realizar para deslocar um equivalente grama de nutriente no solo.

BULL (1986) chama atenção que vários autores sugerem apenas o termo final da equação anterior, ou seja, a relação da atividade para o ion potássio de solução $a K \sqrt{a(C a+M g)}$, ou seu logarítmo, $\mathrm{pK}-0,5 \mathrm{p}(\mathrm{Ca}+\mathrm{Mg})$, também denominado potencial potássio-cálcio-magnésio, como uma indicação satisfatória da disponibilidade imediata de potássio às plantas.

Para BARROWS et al. (1965) os solos são deficientes em potássio, quando $\Delta \bar{G}$ for menor que -6000 Cal/equivalente; todavia, KHASAWNEH (1971) sugeriu -3500 calorias/equivalente como limite.

WOODRUFF (1955), afirma que os valores de pK - 0,5 pCa entre 1,8 a 2,2 representam equilibrio adequado entre cálcio e potássio para a nutrição de plantas. Chama também a atenção o autor que para valores maiores que 2,6 ocorrem deficiências de potássio e valores menores que 1,5 ocorrem absorção excessiva de potássio ou deficiência de cálcio. Estes dados foram confirmados por BULL (1986) que observou deficiência de $\mathrm{K}$ em valores de $\mathrm{pK}-0,5 \mathrm{p}(\mathrm{Ca}+\mathrm{Mg})$ maiores que 2,6 para cultura de gramineas isoladas e consorciadas e leguminosa consorciada.

BRAGA (1972), pesquisando vinte e um solos de Minas Gerais, encontrou os valores de 1,64 a 2,714 para potenciais daqueles solos e identificou o valor de 2,039 como nível crítico de potencial de potássio. Já MOSS \& COULTER (1964) encontrou o valor 2,3 como nivel crítico do potencial de potássio no solo para cultura da bananeira e de 2,8 para cultura do cacau. 


\subsection{Fósforo}

Segundo ROCHE et al. (1980) $65,1 \%$ dos solos tropicais são fortemente deficientes em fósforo e $26,6 \%$ o são ainda medianamente deficientes. Já JACOB et al. (1963) e FASSBENDER (1967) em seus estudos chamam a atenção que $66 \%$ da zona feijoeira da América Latina apresentam o mesmo problema de deficiência, o que constitui um fator limitante na produção do feijão.

No Brasil, 232 ensaios de adubação conduzidos nos estados do Amazonas, Pará, Santa Catarina, Goiás, Minas Gerais, São Paulo, Rio Grande do Sul e Distrito Federal levaram MALAVOLTA (1972) a concluir que as maiores e mais frequentes respostas do feijoeiro foram ao fósforo.

Todavia, FORTUNATO (1982) chama a atenção para alguns solos derivados do calcário do grupo bambuí que apresentam teores elevados de fósforo para a média dos solos tropicais. Para MISI \& KYLE (1990) estes altos teores estarão relacionados com estrutura estomatolíticas, dissiminadas nos pacotes carbonáticos.

Em geral duas categorias de fósforo estão presentes na maioria dos solos, os orgânicos e os inorgânicos. Além destes RUSSEL \& RUSSEL (1968) admitiram o fósforo na solução do solo.

A maioria do fósforo inorgânico está presente nos solos como sais do ácido ortofosfórico, os quais podem ser classificados como fluor-, hidroxi-, e oxifosfatos de ferro, cálcio, alumínio, magnésio, manganês e titânio (LARSEN, 1967). Para CHANG \& JACKSON (1957), estes fosfatos compreendem quatro grupos principais: fosfato de cálcio, de alumínio, de ferro e fosfatos solúveis em redutores, após remoção das três formas anteriores. No entanto, para RUSSEL \& RUSSEL (1968), são classificados em dois grupos: o grupo do fosfato de ferro e aluminio destacando a variscita, estrengita, vivianita e esturenita. E o grupo calcítico dos fosfatos mono, di, tri e octacálcio, hidroxi, cloro e fluoropatita.

$\mathrm{Na}$ solução do solo o ácido ortofosfórico se dissocia de acordo com a reação:

$$
\mathrm{H}_{3} \mathrm{PO}_{4} \leftarrow \mathrm{H}_{2} \mathrm{PO}_{4}^{-} \underset{\mathrm{HPO}}{4} \stackrel{2-}{\leftarrow} \leftarrow \mathrm{PO}_{4}^{3-}
$$


O estudo das reações físico-quimicas dos fosfatos do solo, mostram que entre o $\mathrm{pH} 5$ e 6, para fins práticos, quase todo fósforo em solução encontram-se nas formas absorviveis $\mathrm{H}_{2} \mathrm{PO}_{4}^{-}$e $\mathrm{HPO}_{4}^{2-}$ com predomínio da primeira. Entre pH 6 e 7, as concentrações destas duas formas tendem a igualar, e a maiores valores de $\mathrm{pH}$ a forma $\mathrm{HPO}_{4}^{2-}$ predomina.

Segundo BUEHRER (1932) as concentrações de ions fosfatos na solução do solo são afetadas por presença de $\mathrm{Fe}^{3+}, \mathrm{Al}^{3+}, \mathrm{Ca}^{2+}, \mathrm{Mg}^{2+}$ os quais favorece a formação de uma série de complexos fosfatados de variada solubilidade.

HSU \& JACKSON (1960) observaram que a fração inorgânica do fósforo no solo estava relacionada com $\mathrm{pH}$. Acima de $\mathrm{pH} 7,0$, o fósforo se unia, principalmente, ao cálcio, em pH menor que 7,0, as frações ligadas ao ferro e aluminio aumentavam.

Estudando o comportamento de fosfato monocálcico aplicado a seis solos de Ontário no Canadá, selecionados quanto ao $\mathrm{pH}$, textura e teor de $\mathrm{CaCO}_{3}$, MACKENZIE \& AMER (1964) constataram que em cinco dos solos estudados (pH variando entre 5,3 a 7,2 ) a fração de fósforo ligado ao alumínio foi sempre maior que aquela ligada ao ferro. Apenas em um dos solos estudados ( $\mathrm{pH} 7,6$ e um equivalente a 69,9 de $\mathrm{CaCO}_{3}$ ) a fração do fósforo ligada ao cálcio cresceu e foi maior do que as duas primeiras citadas. Isto está de acordo com CHANG \& JACKSON (1957) quando afirma que em solos com pH neutro e alcalino, onde a forma P-Ca poderá ser dominante, há a formação de P-Al e P-Fe ainda que em menor grau do que em solos ácidos.

A concentração ou mais precisamente, a atividade de fósforo na solução de solos alcalinos ou calcarios pode ser largamente governada por três fatores:

\section{Atividade do $\mathrm{Ca}^{2+}$}

2. A quantidade e tomanho das partículas de carbonato de cálcio livre no solo 3. A quantidade de argila presente

A atividade do fósforo pode ser baixa naqueles solos que possuem uma alta atividade de $\mathrm{Ca}^{2+}$, uma grande quantidade de carbonato de cálcio 
finamente dividido, e uma grande quantidade de argila saturada em cálcio. Contrariamente, em sequência para manter um nivel conhecido da atividade de fosfato na solução do solo, é necessário adicionar grandes quantidades de fertilizantes fosfatados em tais solos.

Segundo McGEORGE \& BREAZEALE (1931), a formação de complexos carbonato-fosfato nos quais um mol de carbonato de cálcio é combinado com três moles de fosfato tricálcico é causado por a baixa disponibilidade de fósforo em solos calcários. Os autores sugerem que a solubilidade do fosfato da rocha é grandemente reduzida quando carbonato de cálcio está presente na fase sólida.

BOISCHOT et al. (1950) chamam atenção que a solubilidade do fosfato é fixada sobre a superfície do carbonato de cálcio por um fenômeno de sorção, não por precipitação. O fosfato fixado desta maneira pode ser usado pelas plantas em decorrência do fenômeno de dessorção para a solução do solo.

BUEHRER (1932), observou que a solubilidade de fosfato em solo saturado com cálcio foi diretamente proporcional a concentração de íons hidrogênio e inversamente proporcional a concentração de ions de cálcio. Já RAVIKOVITCH (1939) e GARDNER \& KELLEY (1940) chamam atenção que nos solos dominados por sódio, a solubilidade do fosfato é muito maior do que em solos dominados por cálcio.

RAGLAND \& SEAY (1957) estudaram o efeito do cálcio trocável sobre a fixação do fósforo pela fração argila de quatro solos Podzólicos de Kentucky (USA), verificaram que, nas argilas previamente acıdificadas, a fixação do fósforo aumentou quando a saturação do cálcio cresceu de $60 \%$. Admitem os autores que a retenção do fósforo foi devida à formação de fosfatos de cálcio e à ligação $\mathrm{H}_{2} \mathrm{PO}_{4}^{-}$- cálcio - micela.

Para LINDSAY et al. (1962), o fosfato aplicado em solos com elevado teor de cálcio e em solos alcalinos precipita-se usualmente como fosfato bicálcico bihidratado $\left(\mathrm{CaHPO}_{4} \cdot 2 \mathrm{H}_{2} \mathrm{O}\right)$ elou fosfato octacálcico ( $\left[\mathrm{Ca}{ }_{4} \mathrm{H}\left(\mathrm{PO}_{4}\right)_{3}\right.$. $\left.3 \mathrm{H}_{2} \mathrm{O}\right]$ ). Tais compostos reagem com a solução de solo, formando apatita. HUFFAMAN (1962) coloca a solubilidade destes compostos na seguinte ordem decrescente: fosfato bicálcico bihidratado, fosfato octacálcico, hidroxi-apatita.

SEN GUPTA \& CORNFIELD (1962), observaram que fosfatos solúveis aplicados em solos com alto teor de $\mathrm{CaCO}_{3}(16,5 \%)$ foram largamente 
fixados como fosfatos não apatíticos e como formas facilmente removiveis. Solos com baixos teores de $\mathrm{CaCO}_{3}(0,15 \%)$ apresentaram, além destas formas, fósforo ligado ao alumínio e ferro. Em nenhum caso foi verificada a presença de apatitas. A maior percentagem de fixação ocorreu nas primeiras 24 horas e decresceu com o aumento da concentração de fosfato. Não se verificou correlação significativa entre a fixação de fósforo e teores de $\mathrm{CaCO}_{3}$, quando estes variaram de $0,5 \%$ a $47,2 \%$.

$\mathrm{O}$ magnésio também reage com o fosfato adicionado aos solos, formando fosfato dimagnésio trihidratado $\left(\mathrm{MgHPO}_{4}, 3 \mathrm{H}_{2} \mathrm{O}\right)$ e/ou fosfato trimagnésico $\left(\left[\mathrm{Mg}_{3}\left(\mathrm{PO}_{4}\right)_{2}\right]\right)$. Por dissolução, o fosfato dimagnésico forma o fosfato trimagnésico, menos solúvel em água (RACZ \& SOPER, 1967).

\subsection{Enxofre}

Da mesma forma que o $\mathrm{N}$ e o $\mathrm{P}$, o $\mathrm{S}$ encontra-se no solo na forma inorgânica e orgânica. Em forma geral, o $S$ total dos solos varia entre 0,003 a 1\%, com média de $0,07 \%$. Em regiões tropicais, os solos inorgânicos apresentam teores de 0,02 a $0,2 \%$ e os orgânicos podem ter até $1 \%$.

Na maioria dos solos de regiões temperadas, de 60 a $90 \%$ do S está em forma orgânica e em regiōes tropicais a variação pode ser mais ampla, sendo que em solos muito intemperizados e com baixos teores de matéria orgânica, o $S$ orgânico é relativamente baixo, menor que $10 \%$ do total e em alguns solos da África, tão alto que chega a $100 \%$, mas com teores relativamente baixos.

O enxofre, na maior parte de terrenos agriculturáveis, se encontra na forma de matéria orgânica, sulfatos solúveis na solução do solo ou adsorvidos no complexo sortivo do solo.

Em solos áridos ou semi-áridos, como a microrregião de Irecê-BA, o $\mathrm{SO}_{4}^{2-}$ precipita em grandes quantidades como sulfatos de $\mathrm{Na}, \mathrm{K}, \mathrm{Ca}, \mathrm{Mg}$. Em solos ácidos argilosos, é adsorvido em argilas 1:1 ou óxidos hidratados de $\mathrm{Fe}$ e Al.

Para BOLAN et al. (1993) nos solos calcários o $\mathrm{Ca}^{2+}$ é atraído eletrostaticamente e superficial de argilo-minerais gerando cargas positivas. $O$ $\mathrm{SO}_{4}^{2-}$ por sua vez também é atraido para o sítio positivo onde fica adsorvido, diminuindo consequentemente sua disponibilidade nos solos. 
Segundo ALVAREZ (1988), a solubilidade dos sulfatos diminui conforme os seguintes cátions acompanhantes:

$\mathrm{K}$ e $\mathrm{Na}>\mathrm{Ca}$ e $\mathrm{Mg}>\mathrm{Al}$ e $\mathrm{Fe}$, sendo os primeiros, dominantes em solos alcalinos e os últimos, em solos ácidos.

Respostas a enxofre tem sido observadas em São Paulo, Goiás, no Planalto Central do Brasil, em culturas de café, milho, algodão, feijão e soja, especialmente em solos de vegetação de cerrado (HIROCE \& GALLO, 1972).

O feijoeiro requer $25 \mathrm{~kg}$ de enxofre por hectare para produzir uma tonelada de grãos (OLIVEIRA \& TUNG, 1988). Embora sejam escassos os trabalhos de calibração para enxofre (ALVAREZ, 1988), teores no solo na faixa de 10 a $15 \mathrm{ppm}$ podem ser considerados como o nível crítico para este nutriente(ROCHA \& MALAVOLTA, 1988 e FERRARI NETO, 1991).

Segundo MALAVOLTA (1952) em feijoeiro,como também em arroz, algodão e cana de açúcar, observa-se um teor de enxofre acima do teor de fósforo.

\subsection{Boro}

Nos solos brasileiros, os teores de boro encontram-se geralmente, nas faixas de 0,06 a $0,5 \mathrm{mg} / \mathrm{dm}^{3}$ e 30 a $60 \mathrm{mg} / \mathrm{dm}^{3}$, para a quantidade disponivel e total, respectivamente (MALAVOLTA, 1980).

Solos com baixo teor de matéria orgânica e alto teor de hidróxidos de ferro e alumínio tem apresentado, segundo CHAPMAN \& VANSELOW (1955), deficiência de B. Também para BRASIL SOBRINHO (1966), GUPTA (1968) e CASAGRANDE (1978), o B está contido nas combinações orgânicas e é liberado daí para as plantas pela decomposição microbiana.

HOROWITZ \& DANTAS (1973), comentam que solos derivados de material clástico, calcário, folhelhos e especialmente argilas marinhas são relativamente ricos em boro.

Já REISENAUER et al. (1973) afirmam que em solos de regiões alcalinos com altos teores de $\mathrm{B}$, o micronutriente adsorvido constitui o reservatório lábil, a partir do qual a concentração de borato na solução do solo é mantida, enquanto que, em solos ácidos e com baixos teores de matéria orgânica, o 
principal reservatório desse nutriente são os minerais contendo boro, os quais são vagarosamente intemperizados.

GUPTA (1979) encontrou correlação negativa entre a absorção de boro pelas plantas e o pH do solo. Todavia, para COOK \& MILLAR (1939), esta relação não é consistente, uma vez que já foi observada deficiência de boro em solos ácidos e ausência de deficiência em solos alcalinos. Da mesma forma BRASIL SOBRINHO (1965), obteve teores mais altos de boro em solos com pH mais alto do que naqueles de $\mathrm{pH}$ mais baixo, usando como extrator água quente.

Estudos semelhantes foram realizados por PETERSON \& NEWMAN (1976) que mostraram correlação negativa, entre pH do solo e a absorção de boro pelas plantas, para valores de $\mathrm{pH}$ acima de 6,3-6,5, não mostrando a mesma tendência definida para $\mathrm{pH}$ abaixo de 6,5.

$\mathrm{A}$ adsorção de boro varia relativamente pouco quando o $\mathrm{pH}$ variar na faixa ácida ( $\mathrm{pH} \mathrm{4,0} \mathrm{a} \mathrm{7,0)} \mathrm{(SCHALSCHA} \mathrm{et} \mathrm{al.,} \mathrm{1973).} \mathrm{Já} \mathrm{na} \mathrm{faixa} \mathrm{alcalina} \mathrm{a}$ retenção de boro aumenta em função da fixação do mesmo, sendo normalmente liberado pelo abaixamento do $\mathrm{pH}$ do solo ao seu nivel original (OLSON \& BERGER, 1946).

Para KEREN \& BINGHAM (1985) quando o pH se encontra próximo a 9,0 , a espécie $\mathrm{B}(\mathrm{OH})^{4-}$ aumenta rapidamente, diminuindo a disponibilidade de boro na solução do solo. Podendo grande parte do boro precipitar pela reação com $\mathrm{CaCO}_{3}$, e isto acontece quanto maior for a concentração de boro na solução.

Segundo JONES \& SCARSETH (1944) plantas de alfafa, aveia e tabaco extraem diferentes quantidades de cálcio e boro de acordo com as suas disponibilidades no solo. A planta terá um desenvolvimento normal quando existir um equilíbrio na absorção de cálcio e boro, sendo desfeito o equilíbrio, em função de uma pequena absorção de cálcio como ocorre em solos ácidos, a planta terá uma maior tolerância a deficiência de boro. Já em solos com pequenas quantidades de cálcio trocável (muito ácido) a adição de pequenas doses de boro pode causar fitotoxidez. Nos solos alcalinos ou em solos que tenham recebido uma super calagem as plantas necessitam de mais boro do que normalmente é exigido em solos ácidos.

RIBEIRO \& BRAGA (1974), estudando solos de Minas Gerais, classificados como LE, LV e LR, observaram que a adsorção do boro condicionouse ao $\mathrm{pH}$ situado nas faixas alcalinas e que o cálcio teve participação ativa na 
retenção de boro pelo solo. Segundo os autores solos mais novos apresentaram maior capacidade de adsorção do boro e não foi encontrada, nas condições do trabalho, correlação entre adsorção de boro e teores de argila, matéria orgânica e óxidos livres de ferro e aluminio.

\subsection{Cobre}

O cobre no solo existe, predominantemente, na forma cúprica $\left(\mathrm{Cu}^{2+}\right)$, aparecendo em maior proporção adsorvido os minerais de argila; aos hidrioxidos de ferro e matéria orgânica (MALAVOLTA, 1980).

A maior disponibilidade deste elemento se dá na faixa de $\mathrm{pH} 5,0$ 6,5 .

Segundo MALAVOLTA \& MURAOKA (1991), as deficiências deste nutriente não são frequentes como as do zinco em solos com pH elevados, uma vez que o $\mathrm{Cu}$ da matéria orgânica vai sendo liberado lentamente. Afirmam também os autores que solos arenosos com baixos teores de matéria orgânica podem tornar-se deficientes em cobre em função das perdas por lixiviação. Solos argilosos, normalmente, tem menores probabilidades de apresentarem deficiências deste micronutriente.

Segundo LINDSAY (1972) com o aumento do $\mathrm{pH}$, grande parte do cobre é adsorvido, permanecendo todavia uma pequena fração solúvel em equilibrio. O cobre é também encontrado como sais solúveis, carbonatos e óxidos, no entanto o aumento na concentração de carbonatos, não implica em diminuição da concentração de cobre na saturação do solo.

A explicação segundo TISDALE et al. (1985) para o aumento da adsorção do cobre com a elevação do $\mathrm{pH}$ poderam ser:

1. Aumento no número de sítios $\mathrm{pH}$ - dependentes nos colóides;

2. Menor competição com ions $\mathrm{H}^{+}$;

3. Possíveis mudanças no estado de hidrólise do cobre na solução do solo

MALAVOLTA (1980) chama atenção que altas concentrações de cobre, no meio, diminuem a absorção de ferro, molibdênio e zinco. Como também altas concentrações de zinco, fósforo e molibdênio diminui a absorção do $\mathrm{Cu}$. 


\subsection{Ferro}

O ferro se encontra em grandes quantidades nos solos, sobretudo nos solos tropicais. As plantas precisam de ferro em quantidades infimas, particularmente para formação de clorofila; como papel enzimático, pois a clorofila não contém ferro na sua molécula.

Segundo OLIVEIRA \& THUNG (1988), os teores de ferro total no solo variam de $3 \%$ até os valores acima de $30 \%$.

O ferro dos solos provém, principalmente, dos minerais ferruginosos da rocha-mãe, notadamente das olivinas, piroxênios, biotita, hematita e magnetita. Segundo BOYER (1971), uma ausência, ou baixos teores desses minerais, não quer dizer que o solo esteja desprovido de ferro, porque este elemento existe como impureza em muitas rochas ou mesmo minerais. Entretanto, para o autor, são frequentes os casos de carências em solos carregados em calcário, sobretudo pó calcáreo muito fino, que é chamado de "calcáreo ativo".

Para MALAVOLTA \& MURAOKA (1991), a deficiência, no caso de solos calcários é, muitas vezes, atribuída à causas fisiológicas.

Segundo MENGEL \& GEURTZEN (1986) a deficiência de ferro em plantas desenvolvidas sobre solos calcários, muitas vezes é confundido com um efeito das altas concentrações de carbonatos e $\mathrm{Ca}^{2+}$ sobre a disponibilidade de ferro, ou ainda por se pensar que o solo apresenta baixos niveis deste elemento. Todavia, tem sido demonstrado que o efeito observado seja causado por excesso de $\mathrm{HCO}_{3}^{-}$, cujas as altas concentrações provocam uma inibição na capacidade de redução de raiz, absorção de $\mathrm{Fe}$, translocação para as folhas e imobilização do ferro no interior das plantas. O bicarbonato segundo YANG (1993) decresce as concentrações e absorção de ferro na parte aérea de cultivares de arroz ineficientes em zinco.

LINDSAY (1979) mostra que $\mathrm{Fe}^{3+}$, é a forma de $\mathrm{Fe}$ utilizada por plantas, e tem excessivamente baixa solubilidade em solos de $\mathrm{pH} 7$ e acima, e que a solubilidade do ferro decresce por três ordens de magnitude para o aumento de cada unidade de pH. ROMHELD \& MARSCHNER (1986) relataram que a solubilidade do $\mathrm{Fe}^{3+}$ acima de $\mathrm{pH} 5$ é limitado para o uso pela planta e que a planta interfere por alterar a química da rizosfera, mobilizando Fe para utilização e absorção pelas plantas. 
Muitas características fisiológicas da planta associadas com deficiência de Fe estão sob controle genético, e estas características podem ser selecionadas por procedimento rotineiro de melhoramento de plantas, o que representa a possibilidade de controle da clorose-deficiência de ferro, mudando a planta para acomodar problemas peculiares do solo em vez da difícil conexão das propriedades químicas do solo para satisfazer a planta (BROWN et al., 1972).

CHAUDHRY \& WALLACE (1976) afirma que o ferro compete inibindo a absorção de zinco na cultura do arroz em solução nutritiva. $O$ efeito é mais pronunciado nos brotos do arroz em baixa concentração de zinco $(5 \mu \mathrm{M}$ de $\mathrm{Zn}$ ) a mais encontrada no solo.

$\mathrm{Na}$ ausência de $\mathrm{Fe}$ a percentagem de $\mathrm{Zn}$ total nos brotos são $29 \%$, porém somente $19 \%$ na presença. Este estudo tem confirmado a suspeita que ferro leva a redução e causa deficiência de zinco em plantas de arroz e baixa a eficiência da adição de fertilizantes.

Quanto ao nível crítico de ferro no solo ELGALA et al. (1986), em experimentos conduzidos em vasos com solos calcários do Egito, usando como extrator o DTPA sugere o nivel crítico de $3,8 \mathrm{mg} / \mathrm{dm}^{3}$.

\subsection{Manganês}

$\dot{E}$ depois do ferro, o mais abundante micronutriente na crosta terrestre.

Segundo DANTAS (1971) e MONIZ (1972), concentrações acima de 20 ppm de $\mathrm{Mn}$ no solo são suficientes para as plantas. Todavia, para KLANT (1969), niveis acima de $20 \mathrm{ppm}$ são tóxicos, enquanto que inferiores a $2,5 \mathrm{ppm}$ pode ser insuficientes para algumas plantas.

A maior disponibilidade de manganês ocorre na faixa de $\mathrm{pH}$ 5,0-6,5. Todavia, afirmam MALAVOLTA \& MURAOKA (1991), que se o pH subir acima de 6, haverá o perigo de que a deficiência possa ocorrer devido à formação de óxidos de $M n$ insolúveis. A redução na disponibilidade de manganês é de 100 vezes para aumento de uma unidade no $\mathrm{pH}$ do solo. Segundo os autores, desbalanços em relação a cálcio, magnésio e ferro podem causar a deficiência de manganês. 
Em função da baixa solubilidade do manganês em solos calcários, FAHAD (1987) trabalhando com, $0^{54} \mathrm{Mn}$ demonstrou que o fenômeno de adsorção química entre $\mathrm{CaCO}_{3}$ e $\mathrm{Mn}^{2+}$ poderia explicar a baixa mobilidade do ${ }^{54} \mathrm{Mn}$, e que a adição de EDTA, como agente quelante, permitiu uma grande recuperação do $\mathrm{Mn}^{+2}$ adicionado ao solo.

Estudando o efeito do bicarbonato e temperatura na zona da raiz (RZT) sobre a absorção de $\mathrm{Zn}, \mathrm{Fe}, \mathrm{Mn}$ e $\mathrm{Cu}$ em cultivares de arroz YANG et al. (1993) chegaram a conclusão que o bicarbonato deprimiu não só o acúmulo de manganês na parte aérea dos cultivares de arroz susceptiveis a deficiência de zinco, como também o acúmulo de ferro.

Trabalhando com solos calcários do Egito, em experimentos conduzidos em vaso ELGALA (1986) estimou em $1,2 \mathrm{mg} / \mathrm{dm}^{3}$ como nível crítico de manganês no solo, extraído com DTPA.

\subsection{Zinco}

Segundo VALADARES \& CATANI (1975), o material de origem è o fator preponderante para condicionar os teores de zinco dos solos. E que os solos derivados de rochas básicas, mais ricos em zinco, tem os teores médios ponderados dos horizontes $A$ e de seus perfis compreendidos entre 87 e 315 $\mathrm{mg} / \mathrm{dm}^{3}$; os materiais aluviais e coluviais, 53 e $84 \mathrm{mg} / \mathrm{dm}^{3}$; os derivados de sedimentos modernos, entre 29 e $65 \mathrm{mg} / \mathrm{dm}^{3}$; os derivados de arenito de Bauru, entre 13 e $30 \mathrm{mg} / \mathrm{dm}^{3}$; os derivados de sedimentos modernos arenosos, entre 1 a $17 \mathrm{mg} / \mathrm{dm}^{3}$, os mais pobres em zinco.

A maior disponibilidade do zinco ocorre na faixa de $\mathrm{pH}$ 5,0 e 6,5. Nos solos calcários, acredita-se que a carência de $\mathrm{Zn}$ seja devida ao baixo produto de solubilidade do elemento nos complexos formados com os colóides e o carbonato. Como no caso do manganês, a disponibilidade do zinco reduz de 100 vezes para cada acréscimo de uma unidade no $\mathrm{pH}$ (MALAVOLTA \& MURAOKA, 1991).

Trabalhando com 20 solos calcários, YASREBI et al. (1994) encontrou que a quantidade trocável de $\mathrm{Zn}^{+2}$ é muito baixa, pois na maior parte o zinco é encontrado em formas insolúveis de precipitados de oxi-hidróxidos de $\mathrm{Fe} e$ 
$\mathrm{Mn}$, e carbonato. Segundo os autores a adição de $\mathrm{ZnSO}_{4}$ nos solos, aumenta a fração carbonatada, o que causa a baixa recuperação de $\mathrm{Zn}^{-2}$ nos solos.

Todavia GUPTA et al. (1987) estudando o efeito do $\mathrm{pH}$ sobre reações de adsorção de zinco em solos alcalinos, indicam que o aumento no $\mathrm{pH}$ do solo aumenta a carga negativa, aumentando também a permeabilidade do zinco. Para o autor 0 alto $\mathrm{pH}$ comumente observado em solos alcalinos, precipitam reações controlando a solubilidade do zinco.

FORNO et al. (1975) considera que o bicarbonato tem sido o maior causador da deficiência de zinco em arroz sobre solo calcário. Segundo o autor o bicarbonato pode inibir absorção de zinco pelas raízes, ao imobilizar o zinco nas raizes, inibe a translocação para a parte aérea.

Para YANG (1993), o bicarbonato decresceu as concentrações e absorção total de zinco na parte aérea de cultivares de arroz "ineficientes-Zn", mas não em cultivares "eficientes- $Z n$ ".

CARVALHO et al. (1977), trabalhando com solos calcários da microrregião de Irecê-BA, não encontrou resposta às aplicações de zinco, para cultura do feijoeiro. Por sua vez FANNING (1985), observou não só deficiência de zinco, como fósforo e nitrogênio em feijoeiro no Vale do Rio Vermelho de Minnesota e North Dakota a maior área de produção de sementes de feijoeiro comum.

SAKAL (1982) determinando nivel critico de zinco em solo e planta, usando como extrator O DTPA em 23 solos calcários, encontrou inicialmente correlação negativa com $\mathrm{pH}\left(\mathrm{r}=-0,41^{\star}\right)$, correlação positiva com carbono orgânico $\left(r=0,71^{\star \star}\right)$ e com a concentração de zinco no tecido da planta de arroz $\left(r=0,93^{\star \star}\right)$. Já o nível crítico, concentração de zinco no solo e planta abaixo do qual a planta responde a aplicação de zinco no solo $0,78 \mathrm{mg} / \mathrm{dm}^{3}$ e $19 \mathrm{mg} / \mathrm{kg}$ respectivamente. Semelhantemente ELGALA (1986), trabalhando com solos calcários do Egito encontrou nivel crítico nestes solos de $0,70 \mathrm{mg} / \mathrm{dm}^{3}$. 


\section{MATERIAL E MÉTODOS}

Foram estudadas amostras da superfície de quatro solos calcários, um Latossolo Vermelho-Amarelo (LVA), Latossolo Amarelo (LA), Cambissolo Vértico (CV) e um Cambissolo Latossólico (CL), os mais representativos da microrregião de Irecê. As amostras foram extraidas, de 0 a $20 \mathrm{~cm}$ de profundidade, secas ao ar até atingirem 4-6\% de umidade, passadas em peneiras com malhas de $6 \mathrm{~mm}$ de abertura. As subamostras foram retiradas e passadas em peneiras com malhas de $2 \mathrm{~mm}$ para serem efetuadas as análises físicas, mineralogógicas e químicas.

O estudo consistiu de uma caracterização física, mineralógicas e química dos solos e da instalação de dois ensaios em casa de vegetação, em vasos com capacidade de $1,5 \mathrm{dm}^{3}$, utilizando-se como planta teste, o feijoeiro (Phaseolus vulgaris L.).

\subsection{Localização dos Ensaios}

Os ensaios foram instalados e conduzidos em casa de vegetação no Centro de Energia Nuclear na Agricultura - CENA, "Campus" de Piracicaba USP, Estado de São Paulo. 


\subsection{Caracterizações Físicas, Mineralógicas e Químicas das Amostras}

\subsubsection{Análise Granulométrica}

As análises granulométricas foram determinadas de acordo com o método do densimetro, empregado no laboratório de física de solos da Escola Superior de Agricultura "Luiz de Queiroz"- USP (BOYOUCOS, 1927).

\subsubsection{Análise Mineralógica}

A caracterização mineralógica foi realizada utilizando-se difração de raio- $X$ da fração argila e silte. $E$ as lâminas para obtenção dos difratogramas da fração argila das amostras dos solos foi tratada com potássio natural, $350^{\circ} \mathrm{C} \mathrm{e}$ $550^{\circ} \mathrm{C}$, como também com magnésio e magnésio-glicerol (WHITE \& JACKSON, 1947 e JACKSON, 1956).

\subsubsection{Análise Química dos Solos}

As análises químicas iniciais foram executadas com três repetições, sendo:

A) $\mathrm{pH}$ em água, $\mathrm{KCl}$ e $\mathrm{CaCl}_{2}$ - determinado em potenciômetro, com eletrodo de vidro, empregando-se a relação terra-solução 1:2,5 (RAlJ et al., 1987).

B) Matéria orgânica - pelo método colorimétrico (QUAGGIO \& RAIJ, 1979) e da combustão por via seca utilizando o analisador "Carmograph $12 A$ " da $H$. Wösthoff KG. 
C) Fósforo disponivel - para melhor avaliação do fósforo disponivel a extração foi feita pelos extratores resina, Mehlich-1, Olsen e Bray-1. A extração pela resina trocadora de ions seguiu a metodologia proposta por RAIJ \& QUAGGIO (1983), com determinação colorimétrica do complexo fosfomolibdico após redução com ácido ascórbico. A extração por Mehlich-1, na relação solo:solução 1:10 seguiu a metodologia proposta por THOMAS \& PEASLEE (1973). A extração com Olsen (OLSEN et al., 1954), a relação solo:solução foi 1:20 e o tempo de agitação de 30 minutos, com posterior filtragem lenta. E na extração com Bray1, a relação solo:solução foi 1:10, com agitação por cinco minutos, procedendose centrifugação a $3500 \mathrm{rpm}$, por cinco minutos e posterior filtragem, adicionouse uma gota de ácido sulfúrico concentrado, para diminuir o $\mathrm{pH}$ do extrato, tornando-o mais límpido e favorecendo o desenvolvimento da coloração (BRAY \& KURTZ, 1945).

D) Enxofre disponivel - extraido com $\mathrm{NH}_{4} \mathrm{OHC} \quad 0,5 \mathrm{~N}$ em $\mathrm{HOAC} \quad 0,25 \mathrm{~N}$ e determinado por turbidimetria do sulfato de Ba, conforme VITTI (1989).

E) Potássio, cálcio magnésio - extraído pelo método da resina, sendo determinado potássio por fotômetro de chama e o cálcio e magnésio por espectrofotometria de absorção atômica, segundo RAlJ et al. (1987). Além desta extração, estes cátions conjuntamente com o sódio foram extraídos pelo extrator Mehlich-1.

F) Alumínio trocável - extraído por solução $1 \mathrm{~N}$ de $\mathrm{KCl}$ e titulado com solução 0,025N de hidróxido de sódio (RAlJ et al., 1987).

G) Acidez potencial $\left(\mathrm{H}^{+}+\mathrm{Al}^{3+}\right)$ - determinado potenciometricamente pela solução tampão SMP (RAlJ et al., 1987).

H) Carbonato de cálcio - determinado através de neutralização com ácido clorídrico $0,5 \mathrm{~N}$, usando como indicador fenolftaleina $1 \%$ em etanol de $60 \%$ e titulado com hidróxido de sódio $0,25 \mathrm{~N}$ segundo RICHARDS, L.A. (1954).

I) Soma de bases trocáveis, (S) - soma dos teores de $\mathrm{K}, \mathrm{Ca}, \mathrm{Mg}$ e $\mathrm{Na}$ trocáveis. 
J) Capacidade de troca, (T) - soma de $\mathrm{S}+\mathrm{H}^{+}+\mathrm{Al}^{3+}$.

K) Saturação de bases, (V\%) - a percentagem das bases no complexo sortivo do solo $\mathrm{V} \%=\mathrm{S} / \mathrm{T} .100$.

L) Saturação de aluminio $(\mathrm{m} \%)$ - a saturação de alumínio, representada por $\mathrm{m} \%$ foi calculada pela expressão: $\mathrm{m} \%=\mathrm{Al}^{3+} /\left(\mathrm{S}+\mathrm{Al} \mathrm{l}^{3+}\right) \cdot 100$

M) Cobre, ferro, manganês e zinco - foi extraído com DTPA (ácido dietilenotriaminopentaacético) tamponado a pH 7,3 (RAIJ et al., 1987). Como também foi usado o extrator Mehlich-1.

N) Boro - utilizado o extrator Mehlich-1, determinando-se o boro extraido por colorimetria com curcumina (TEDESCO et al., 1985). Foi também usado o extrator $\mathrm{CaCl}_{2} 2 \mathrm{H}_{2} \mathrm{O} \quad 0,1 \%$ com extração em banho-maria a $70^{\circ} \mathrm{C}$, mantendo inicialmente em repouso por dez minutos para aquecimento e posterior agitação da suspensão por cinco minutos e aproximadamente $180 \mathrm{rpm}$; após um repouso de duas horas retirou-se uma alíquota do sobrenadante para quantificação com azometina-H (CRUZ \& FERREIRA, 1984).

O) Ataque pelo ácido sulfúrico - foi utilizado $2,0 \mathrm{~g}$ de TFSA, $50 \mathrm{ml}$ de $\mathrm{H}_{2} \mathrm{SO}_{4} \mathrm{e}$ fervura durante uma hora, determinando-se teores de $\mathrm{SiO}_{2}, \mathrm{Al}_{2} \mathrm{O}_{3}$ e $\mathrm{Fe}_{2} \mathrm{O}_{3}$, conforme VETTORI (1969). As relações $\mathrm{Ki}$ e $\mathrm{Kr}$, ou seja, as relações $\mathrm{SiO}_{2} / \mathrm{Al}_{2} \mathrm{O}_{3}$ e $\mathrm{SiO}_{2} / \mathrm{Al}_{2} \mathrm{O}_{3}+\mathrm{Fe}_{2} \mathrm{O}_{3}$ foram calculadas sob forma molecular.

\subsection{Experimentos em Casa de Vegetação}

\subsubsection{Delineamento Experimental e Análise Estatística}

\subsubsection{Estudo da relação $K /(\mathrm{Ca}+M g)$}

Foi utilizado um delineamento inteiramente casualizado, envolvendo oito tratamentos com três repetições para o $\mathrm{LA}, \mathrm{CV}$ e $\mathrm{CL}$ e apenas quatro niveis de $\mathrm{K}$ portanto, quatro tratamentos com seis repetições para o LVA. 
A tabela 1 mostra os níveis de $\mathrm{K}, \mathrm{Ca}, \mathrm{Mg}$ e valores da relação $\mathrm{Ca} / \mathrm{Mg}$.

Tabela 1. Niveis de $\mathrm{K}, \mathrm{Ca}, \mathrm{Mg}$ e valores da relação $\mathrm{Ca} / \mathrm{Mg}$

\begin{tabular}{|c|c|c|c|c|}
\hline \multirow{2}{*}{$\begin{array}{c}\text { Relação } \\
\mathrm{K} /(\mathrm{Ca}+\mathrm{Mg})\end{array}$} & \multicolumn{3}{|c|}{ Niveis dos Elementos } & \multirow{2}{*}{$\begin{array}{l}\text { Relação } \\
\mathrm{Ca} / \mathrm{Mg}\end{array}$} \\
\hline & $\mathrm{K}$ & $\mathrm{Ca}$ & $\mathrm{Mg}$ & \\
\hline $\mathrm{Ko} /(\mathrm{Cao}+\mathrm{Mgo})$ & $\mathrm{KO}$ & Cao & Mgo & \\
\hline $\mathrm{K} 1 /(\mathrm{Cao}+\mathrm{Mgo})$ & K1 & & & Original \\
\hline $\mathrm{K} 2 /(\mathrm{Cao}+\mathrm{Mgo})$ & $\mathrm{K} 2$ & & & \\
\hline $\mathrm{K} 3 /(\mathrm{Cao}+\mathrm{Mgo})$ & K3 & & & \\
\hline $\mathrm{K} 4 /(\mathrm{Cao}+\mathrm{Mg} 1)$ & K4 & Cao & Mg1 & \\
\hline $\mathrm{K} 5 /(\mathrm{CaO}+\mathrm{Mg} 1)$ & K5 & & & $3,30 / 1$ \\
\hline $\mathrm{K} 6(\mathrm{CaO}+\mathrm{Mg} 1)$ & $\mathrm{K} 6$ & & & \\
\hline $\mathrm{K} 7(\mathrm{Cao}+\mathrm{Mg} 1)$ & $\mathrm{K} 7$ & & & \\
\hline
\end{tabular}

As análises estatísticas foram efetuadas com o auxilio de um computador 486 DX 66 . Foi realizada análise de variância dos dados de produção de grãos de feijão; de matéria seca de: folhas, raizes, caules + ramos, vagem e matéria seca total; da concentração de potássio, cálcio e magnésio na planta; teores de cálcio e magnésio trocáveis e potássio disponivel do solo.

A comparação entre as médias foi feita pelo teste de Tukey ao nivel de $5 \%$ de probabilidade.

Foram também, estabelecidas equações lineares e quadráticas entre os valores de niveis das relações $\mathrm{K} /(\mathrm{Ca}+\mathrm{Mg})$ no solo versus todos os parâmetros anteriormente citados. 


\subsubsection{Diagnose de $P$, $S$ e Micronutrientes}

Também foi utilizado o delineamento experimental inteiramente casualizado - utilizando-se a técnica de diagnose por subtração (MALAVOLTA \& MURAOKA, 1985), envolvendo nove tratamentos com três repetições, constituídos da seguinte maneira:

1. Adubação completa (completo)

2. Solo natural (testemunha)

3. Adubação completa com a omissão de fósforo (-P)

4. Adubação completa com a omissão de enxofre $(-S)$

5. Adubação completa com a omissão de boro (-B)

6. Adubação completa com a omissão de cobre $(-\mathrm{Cu})$

7. Adubação completa com a omissão de ferro (-Fe)

8. Adubação completa com a omissão de manganês $(-\mathrm{Mn})$

9. Adubação completa com a omissão de zinco (-Zn)

Cada parcela foi constituida por um vaso com dreno. Sendo realizada análise de variância de produção de grãos de feijão; de matéria seca de: folhas, raizes, caule+ramos, vagem e matéria total; teores de $P, K, C a, M g, S, B$, $\mathrm{Cu}, \mathrm{Fe}, \mathrm{Mn}$ e $\mathrm{Zn}$ na planta e no solo.

A comparação entre as médias foi feita pelo teste de Tukey ao nivel de $5 \%$ de probabilidade.

\subsubsection{Instalação e Condução dos Experimentos}

\subsubsection{Estudo da Relação K/(Ca+Mg)}

As amostras do solo para o cultivo do feijoeiro foram divididas em subamostras correspondentes ao volume do vaso $\left(1,5 \mathrm{dm}^{3}\right)$. Utilizaram-se vasos com dreno, onde as subamostras juntamente com os teores de potássio e 
magnésio nas doses desejadas contidas na (tabela 2), foram incubadas, mantendo-se a umidade em torno de $80 \%$ da capacidade de campo por um período de 30 dias.

As doses de potássio a serem atingidos para os solos LVA e LA foram calculadas em função dos teores iniciais de potássio, cálcio e magnésio (tabela 3), e para os solos CV e CL foi calculado em função da percentagem na CTC dos solos, 2,4 e $5 \%$ de T e 4, 5 e $6 \%$ de $\mathrm{T}$, respectivamente.

As doses de magnésio para o LA, $\mathrm{CV}$ e $\mathrm{CL}$ foram determinadas com o intuito de baixar a relação $\mathrm{Ca} / \mathrm{Mg}$ para 3,30 , relação semelhante a relação original do LVA (tabela 3 ).

Após o período de incubação, o solo de cada vaso foi removido, destorroado, homogeneizado e coletadas amostras de terra para análise química. Em seguida, foram feitas adubaçōes de plantio segundo MALAVOLTA \& MURAOKA (1985) com $200 \mathrm{mg} / \mathrm{dm}^{3}$ de $\mathrm{N}$ dividido em quatro aplicações iguais; 200 $\mathrm{mg} / \mathrm{dm}^{3}$ de P; $30 \mathrm{mg} / \mathrm{dm}^{3}$ de $S$ e $1 ; 2 ; 30 ; 15 ; 0,1$ e $4 \mathrm{mg} / \mathrm{dm}^{3}$ de B; Cu; Fe; Mn; Mo e $\mathrm{Zn}$ respectivamente.

No dia seguinte, foram semeadas no solo seis sementes de feijão por vaso e foi efetuado o desbaste sete dias após a emergência, deixando-se duas plantas por vaso.

Os vasos foram irrigados diariamente com água destilada, procurando-se manter o teor de umidade próximo à capacidade de campo. Efetuou-se, periodicamente, o rodizio dos vasos.

A colheita foi realizada 40 dias após a semeadura, fazendo-se o corte rente ao solo e acondicionando-se o material vegetal em sacos de papel. 0 material vegetal foi posto para secar em estufa de ventilação forçada a $75^{\circ} \mathrm{C}$, até peso constante.

Após seco e pesado, o material vegetal foi moido em moinho do tipo Wiley e, posteriormente, mineralizado e analisado. 
Tabela 2 . Percentagem de saturação de potássio na CTC, níveis de potássio a ser atingidos $\left(\mathrm{mmol}_{\mathrm{c}} / \mathrm{dm}^{3}\right)$ e quantidades de potássio e magnésio adicionadas em função das relações $\mathrm{K} /(\mathrm{Ca}+\mathrm{Mg})$ aplicadas no LVA, LA, CV e CL.

\begin{tabular}{|c|c|c|c|c|c|c|}
\hline $\begin{array}{c}\text { Relacão } \\
\text { K/(Ca+Mg) }\end{array}$ & $\begin{array}{l}\% \text { K na } \\
\text { CTC a ser } \\
\text { atingida }\end{array}$ & $\begin{array}{c}\text { mmol } \mathrm{K} / \mathrm{dm}^{3} \\
\text { a ser } \\
\text { atingido }\end{array}$ & $\begin{array}{l}\text { mmol }_{\mathbf{c}} \mathrm{K} / \mathrm{dm}^{3} \\
\text { a ser } \\
\text { adicionado }\end{array}$ & $\begin{array}{c}\mathrm{mmol}_{\mathbf{c}} \mathrm{Mg} / \mathrm{dm}^{3} \\
\text { a ser } \\
\text { adicionado } \\
\end{array}$ & $\begin{array}{l}\text { g KCl/vaso } \\
\text { aser } \\
\text { adicionado }\end{array}$ & $\begin{array}{l}\mathrm{g} \mathrm{MgCl}_{2} / \text { vaso } \\
\text { a ser } \\
\text { adicionado }\end{array}$ \\
\hline \multicolumn{7}{|c|}{ Latossolo Vermelho Amarelo } \\
\hline $1 / 6,5$ & 12,17 & 17,00 & 0,00 & 0,00 & 0,000 & 0,00 \\
\hline $1 / 5,5$ & 14,39 & 20,10 & 3,10 & 0,00 & 0,345 & 0,00 \\
\hline $1 / 4,5$ & 17,61 & 24,60 & 7,60 & 0,00 & 0,849 & 0,00 \\
\hline $1 / 3,5$ & 22,62 & 31,60 & 14,60 & 0,00 & 1,631 & 0,00 \\
\hline \multicolumn{7}{|c|}{$\underline{\text { Latossolo Amarelo }}$} \\
\hline $1 / 7,7$ & 9,90 & 10,40 & 0,00 & 0,00 & 0,000 & 0,00 \\
\hline $1 / 6,7$ & 11,43 & 12,00 & 1,60 & 0,00 & 0,179 & 0,00 \\
\hline $1 / 5,7$ & 13,43 & 14,10 & 3,70 & 0,00 & 0,414 & 0,00 \\
\hline $1 / 4,7$ & 16,29 & 17,10 & 6,70 & 0,00 & 0,748 & 0,00 \\
\hline $1 / 8,4$ & 9,90 & 10,40 & 0,00 & 7,40 & 0,000 & 1,128 \\
\hline $1 / 7,4$ & 11,33 & 11,90 & 1,50 & 7,40 & 0,167 & 1,128 \\
\hline $1 / 6,4$ & 13,05 & 13,70 & 3,30 & 7,40 & 0,369 & 1,128 \\
\hline $1 / 5,4$ & 15,43 & 16,20 & 5,80 & 7,40 & 0,648 & 1,128 \\
\hline \multicolumn{7}{|c|}{ Cambissolo Vértico } \\
\hline 1137,3 & 0,70 & 2,80 & 0,00 & 0,00 & 0,000 & 0,00 \\
\hline $1 / 48,0$ & 2,01 & 8,00 & 5,20 & 0,00 & 0,581 & 0,00 \\
\hline $1 / 24,2$ & 3,99 & 15,90 & 13,11 & 0,00 & 1,464 & 0,00 \\
\hline $1 / 19,3$ & 5,00 & 19,90 & 17,10 & 0,00 & 1,911 & 0,00 \\
\hline $1 / 170,6$ & 0,70 & 2,80 & 0,00 & 93,50 & 0,000 & 14,256 \\
\hline $1 / 48,8$ & 2,46 & 9,80 & 7,00 & 93,50 & 0,782 & 14,256 \\
\hline $1 / 24,4$ & 4,93 & 19,60 & 16,80 & 93,50 & 1,877 & 14,256 \\
\hline $1 / 19,5$ & 6,15 & 24,45 & 21,70 & 93,50 & 2,426 & 14,256 \\
\hline \multicolumn{7}{|c|}{ Cambissolo Latossólico } \\
\hline $1 / 32,9$ & 2,39 & 3,70 & 0,00 & 0,00 & 0,000 & 0,00 \\
\hline $1 / 19,6$ & 4,01 & 6,20 & 2,50 & 0,00 & 0,279 & 0,00 \\
\hline $1 / 15,8$ & 4,98 & 7,70 & 4,00 & 0,00 & 0,447 & 0,00 \\
\hline $1 / 13,1$ & 6,01 & 9,30 & 5,60 & 0,00 & 0,626 & 0,00 \\
\hline $1 / 35,8$ & 2,39 & 3,70 & 0,00 & 10,80 & 0,000 & 1,646 \\
\hline $1 / 20,1$ & 4,27 & 6,60 & 2,90 & 10,80 & 0,324 & 1,646 \\
\hline $1 / 16,2$ & 5,30 & 8,20 & 4,50 & 10,80 & 0,503 & 1,646 \\
\hline $1 / 13,4$ & 6,40 & 9,90 & 6,20 & 10,80 & 0,693 & 1,646 \\
\hline
\end{tabular}


Tabela 3. Valores médios de potássio, cálcio e magnésio $\left(\mathrm{mmol}_{\mathrm{c}} / \mathrm{dm}^{3}\right)$, relações $\mathrm{Ca} / \mathrm{Mg}$ $\mathrm{K} /(\mathrm{Ca}+\mathrm{Mg})$ e percentagem de potássio, cálcio e magnésio na CTC dos solos estudados

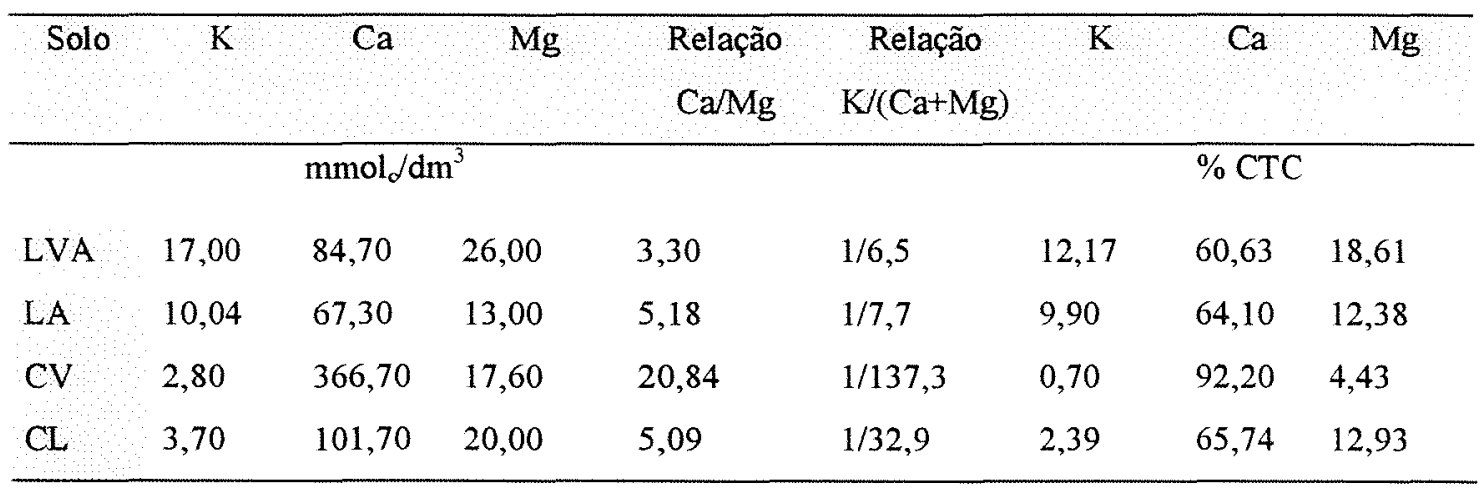




\subsubsection{Diagnose de $P, S$ e Micronutrientes}

A instalação, adubação de plantio e condução do ensaio foi semelhante a do ensaio do estudo da relação $\mathrm{K} /(\mathrm{Ca}+\mathrm{Mg})$. Neste caso, entretanto, nos tratamentos a omissão de um nutriente implicou na completa ausência desse na adubação de plantio.

A diferença básica neste ensaio foi a incubação dos solos, onde as doses de potássio e magnésio foram definidas em função da produção de grãos e de matéria seca total do ensaio relação $\mathrm{K} /(\mathrm{Ca}+\mathrm{Mg}$ ) (tabela 4).

Tabela 4. Doses de potássio e magnésio em $\mathrm{mmol} / \mathrm{dm}^{3}$ e de $\mathrm{KCl}$ e $\mathrm{MgCl}_{2}$ em g/vaso usadas na incubação do ensaio.

\begin{tabular}{|c|c|c|c|c|c|}
\hline Solo & $\begin{array}{c}\text { relação } \\
\mathrm{K}(\mathrm{Ca}+\mathrm{Mg})\end{array}$ & $\mathrm{K}$ & $\mathrm{Mg}$ & $\mathrm{KCl}$ & $\mathrm{MgCl}_{2}$ \\
\hline & & \multicolumn{2}{|c|}{$\mathrm{mmol}_{\mathrm{c}} / \mathrm{dm}^{3}$} & \multicolumn{2}{|c|}{-_-_-_/vaso---_-_-_ } \\
\hline LVA & $1 / 6,86$ & 14,60 & - & 1,631 & - \\
\hline$\perp A$ & $1 / 10,26$ & 5,80 & 7,40 & 0,648 & 1,128 \\
\hline CV & $1 / 377,51$ & - & - & - & - \\
\hline $\mathrm{CL}$ & $1 / 51,83$ & 4,50 & 10,80 & 0,503 & 1,646 \\
\hline
\end{tabular}

Durante a condução do ensaio, foram feitas semanalmente aplicações de inseticida organofosforado DDVP-500, com o intuito de evitar o ataque do virus mosaico dourado (VMD), em razão de existir na casa de vegetação plantas hospedeiras; mesmo assim no final do ciclo, as plantas apresentaram-se afetadas. 


\subsubsection{Análise Química dos Solos}

\subsubsection{Estudo da Relação K/(Ca+Mg)}

Coletaram-se amostras de terra antes da adubação de plantio e após a colheita e foram determinados os teores de potássio, cálcio e magnésio, usando como extrator a resina trocadora de íons, como citado anteriormente (quadro 5).

Com estas amostras também foram determinados valores de potencial potássio-cálcio-magnésio, segundo FASSBENDER \& LAROCHE (1968).

O potencial de potássio em relação ao potencial de cálcio mais magnésio foi expresso em função do logaritmo inverso das atividades iônicas (FASSBENDER, 1972).

$$
\text { Potencial de potássio }=p K-0,5 p(C a+M g)
$$

A atividade do ion ( $\mathrm{K}, \mathrm{Ca}, \mathrm{Mg}$ ) foi calculada em função da concentração analítica (mi) versos o coeficiente de atividade do ion na solução (f)

$$
a=f . m i
$$

Os coeficientes de atividade (f) foram calculados pela equação de Debye-Huckell

$$
\log f=-\frac{A z i^{2} \sqrt{u}}{1+d B \sqrt{u}}
$$

A e B - são constantes cujos valores dependem da natureza do solvente e da temperatura;

$\mathrm{Zi}$ = representa o número de oxidação do ion;

d - raio iônico efetivo do ion;

u - força iônica da solução. 
Tabela 5. Valores médios de potássio, cálcio e magnésio $\left(\mathrm{mmol}_{d} / \mathrm{dm}^{3}\right)$, relações Ca/Mg e $\mathrm{K} /(\mathrm{Ca}+\mathrm{Mg})$ atingidos para os solos LVA, LA, CV e CL.

\begin{tabular}{|c|c|c|c|c|c|c|}
\hline $\begin{array}{c}\mathrm{K} /(\mathrm{Ca}+\mathrm{Mg}) \\
\text { a ser } \\
\text { atingida }\end{array}$ & $\mathbf{K}$ & $\underset{\mathrm{Ca}}{\mathrm{mmol}} \mathrm{d} d \mathrm{~d}$ & $\ldots$ & $\mathrm{Ca} / \mathrm{Mg}$ & \multicolumn{2}{|c|}{ atingida } \\
\hline & \multicolumn{6}{|c|}{ Latossolo Vermelho Amarelo } \\
\hline $1 / 6,5$ & 12,43 & 127,67 & 22,54 & 5,66 & $1 / 12,11$ & $(0,083)$ \\
\hline $1 / 5,5$ & 13,17 & 123,67 & 21,88 & 5,65 & $1 / 11,05$ & $(0,090)$ \\
\hline $1 / 4,5$ & 15,42 & 120,53 & 21,93 & 5,50 & $1 / 9,24$ & $(0,108)$ \\
\hline \multirow[t]{2}{*}{$1 / 3,5$} & 19,56 & 112,33 & 21,87 & 5,13 & $1 / 6,86$ & $(0,145)$ \\
\hline & \multicolumn{6}{|c|}{$\underline{\text { Latossolo }}$ Amarelo } \\
\hline $1 / 7,7$ & 7,31 & 83,26 & 13,36 & 6,23 & $1 / 13,22$ & $(0,076)$ \\
\hline $1 / 6,7$ & 7,80 & 81,93 & 13,54 & 6,03 & $1 / 12,25$ & $(0,082)$ \\
\hline $1 / 5,7$ & 8,65 & 81,33 & 13,14 & 6,19 & $1 / 10,92$ & $(0,092)$ \\
\hline $1 / 4,7$ & 11,09 & 83,67 & 13,92 & 6,01 & $1 / 8,80$ & $(0,114)$ \\
\hline $1 / 8,4$ & 6,09 & 83,87 & 20,26 & 4,14 & $1 / 17,10$ & $(0,058)$ \\
\hline $1 / 7,4$ & 7,55 & 81,13 & 21,48 & 3,78 & $1 / 13,59$ & $(0,074)$ \\
\hline $1 / 6,4$ & 8,04 & 79,86 & 20,26 & 3,94 & $1 / 12,45$ & $(0,080)$ \\
\hline \multirow[t]{2}{*}{$1 / 5,4$} & 9,63 & 78,20 & 20,60 & 3,80 & $1 / 10,26$ & $(0,097)$ \\
\hline & \multicolumn{6}{|c|}{ Cambissolo Vértico } \\
\hline $1 / 137,3$ & 1,15 & 414,66 & 19,48 & 21,29 & $1 / 377,51$ & $(0,003)$ \\
\hline $1 / 48,0$ & 1,78 & 412,66 & 18,48 & 22,33 & $1 / 242,21$ & $(0,004)$ \\
\hline $1 / 24,2$ & 3,27 & 465,33 & 18,59 & 25,03 & $1 / 147,99$ & $(0,007)$ \\
\hline $1 / 19,3$ & 4,26 & 460,00 & 18,26 & 25,19 & $1 / 112,27$ & $(0,009)$ \\
\hline $1 / 170,6$ & 1,04 & 412,66 & 77,93 & 5,30 & $1 / 471,72$ & $(0,002)$ \\
\hline $1 / 48,8$ & 2,23 & 435,33 & 90,18 & 4,83 & $1 / 235,65$ & $(0,004)$ \\
\hline $1 / 24,4$ & 2,56 & 458,66 & 83,50 & 5,49 & $1 / 211,78$ & $(0,005)$ \\
\hline \multirow[t]{2}{*}{$1 / 19,5$} & 4,72 & 409,33 & 77,93 & 5,25 & $1 / 103,23$ & $(0,010)$ \\
\hline & \multicolumn{6}{|c|}{ Cambissolo Latossólico } \\
\hline 1132,9 & 1,87 & 127,00 & 19,21 & 6,61 & $1 / 78,19$ & $(0,013)$ \\
\hline 1119,6 & 2,76 & 131,67 & 20,04 & 6,57 & $1 / 54,73$ & $(0,018)$ \\
\hline $1 / 15,8$ & 3,50 & 130,83 & 20,04 & 6,53 & $1 / 43,11$ & $(0,023)$ \\
\hline $1 / 13,1$ & 4,03 & 131,50 & 20,32 & 6,47 & $1 / 37,67$ & $(0,027)$ \\
\hline $1 / 35,8$ & 1,94 & 128,83 & 26,72 & 4,82 & $1 / 80,18$ & $(0,012)$ \\
\hline $1 / 20,1$ & 3,13 & 130,50 & 28,95 & 4,51 & $1 / 50,94$ & $(0,020)$ \\
\hline $1 / 16,2$ & 3,03 & 129,50 & 27,56 & 4,70 & $1 / 51,83$ & $(0,019)$ \\
\hline $1 / 13,4$ & 3,90 & 132,67 & 27,56 & 4,81 & $1 / 41,08$ & $(0,024)$ \\
\hline
\end{tabular}


A força iônica da solução foi calculada pela seguinte equação:

$$
\mu=1 / 2 \quad \sum_{i=1}^{i=n} m i z^{2}
$$

\subsubsection{Diagnose de $P$, S e Micronutrientes}

Com as amostras de solo coletadas antes da adubação de plantio e após o cultivo, foram determinados os teores de:

1. $P$ disponiveis (extrator Resina e Olsen)

2. $\mathrm{K} / \mathrm{Ca}, \mathrm{Mg}$ trocáveis (extrator resina)

3. $\mathrm{S}$ disponiveis (extrator $\mathrm{NH}_{4} \mathrm{OAc}$ em $\mathrm{HOAC}$ )

4. $\mathrm{Cu}, \mathrm{Fe}, \mathrm{Mn}, \mathrm{Zn}$ (extrator DTPA)

5. B (extrator $\mathrm{CaCl}_{2} 2 \mathrm{H}_{2} \mathrm{O} 0,1 \%$ )

\subsubsection{Análise Química do Material Vegetal}

\subsubsection{Estudo da Relação K/(Ca+Mg)}

Foram feitas as determinações analíticas de potássio, cálcio e magnésio nas folhas na floração e no final do ciclo da cultura e nos grãos do feijoeiro segundo técnica descrita por MALAVOLTA (1964). 


\subsubsection{Diagnose de $P, S$ e Micronutrientes}

O teor e acumulação de fósforo, potássio, enxofre, cálcio, magnésio, boro, cobre, ferro, manganês e zinco nas folhas do feijoeiro (na floração) e nos grãos foram determinadas pelo plasma, com a mineralização feita via úmida, por digestão nítroperclórica, adicionando-se $5 \mathrm{ml} \mathrm{HNO}_{3}$ concentrado e $1,3 \mathrm{ml} \mathrm{HClO}_{4}$ concentrado para $0,5 \mathrm{~g}$ de material seco. 


\section{RESULTADOS E DISCUSSÃO}

\subsection{Características Físicas, Mineralógicas e Químicas dos Solos}

Os resultados apresentados neste item, serviram de orientação para definição da adubação e dos tratamentos dos ensaios conduzidos. Em função da falta de informação na área de química e fertilidade dos solos calcários da microrregião de Irecê-BA, estes resultados também serviram para avaliação inicial da sua fertilidade, uma vez que ainda não foram estabelecidos critérios para análise dos solos desta região semi-árida baiana, nem tão pouco critérios para interpretação de resultados de análises de solo e recomendação de adubação.

\subsubsection{Análises Granulométricas}

A análise granulométrica (tabela 6) mostra que 0 Latossolo Vermelho amarelo (LVA) e o Latossolo Amarelo (LA) apresentam a classe textural argilosa. Já o Cambissolo Vértico (CV) e o Cambissolo Latossólico (CL) apresentam classe textural muito argilosa. Com o aumento do teor de argila nestes dois últimos solos, ocorre aumento na superfície de adsorção, consequentemente fenômenos relacionados à retenção de umidade e a adsorção de fósforo tendem a aumentar.

Pela tabela 6 nota-se também, que as percentagens do grau de floculação são inversamente oproporcionais as variações de argila em água. Segundo CUNHA (1992) nos solos tropicais (muito evoluidos), o ferro, na forma férrica, junto com os minerais de argila caoliníticos, formam microagregados bastante estáveis. Nestas circunstâncias, a argila natural é baixa, sendo alto o 
grau de floculação. O grau de floculação do Cambissolo Vértico, de $84 \%$, indica boas condições de estrutura do solo e resistência à erosão, devido a grande parte de argila encontrar-se floculada.

Tabela 6. Análise granulométrica ${ }^{1}$ das amostras dos solos estudados

\begin{tabular}{|c|c|c|c|c|c|c|c|c|c|c|c|}
\hline \multirow[t]{2}{*}{ Solo } & \multicolumn{6}{|c|}{ Areia } & \multirow[b]{2}{*}{ Silte } & \multicolumn{2}{|c|}{ Argila } & \multirow[t]{2}{*}{ Floculaçăo } & \multirow[t]{2}{*}{ Classe Textural } \\
\hline & MG & G & $M$ & $F$ & MF & Total & & Total & Agua & & \\
\hline & & & & & & $\%$ & & & & & \\
\hline $\begin{array}{l}\text { LVA } \\
\text { LA }\end{array}$ & - & $\overline{1}$ & $\begin{array}{l}11 \\
27\end{array}$ & $\begin{array}{l}13 \\
15\end{array}$ & $\begin{array}{l}3 \\
3\end{array}$ & $\begin{array}{l}27 \\
46\end{array}$ & $\begin{array}{l}22 \\
10\end{array}$ & $\begin{array}{l}51 \\
45\end{array}$ & $\begin{array}{l}32 \\
25\end{array}$ & $\begin{array}{l}38 \\
44\end{array}$ & $\begin{array}{l}\text { argilosa } \\
\text { argilosa }\end{array}$ \\
\hline $\mathrm{CV}$ & - & - & 4 & 8 & 2 & 14 & 22 & 64 & 10 & 84 & muito argilosa \\
\hline$C L$ & - & - & 4 & 13 & 4 & 21 & 16 & 62 & 23 & 63 & muito argilosa \\
\hline
\end{tabular}

1 Metodologia: Método do densimetro - Análise realizada pelo Laboratório de Física do Solo do Departamento de Solo da ESALQ - Piracicaba-SP

- Classe de diâmetro $(\mathrm{mm})$ :

- Com cinco frações de areia : muito grossa $=2-1 ;$ grossa $=1-0,5 ;$ Média $=0,5-0,25 ;$ Fina $=0,25-0,10$; Muito Fina $=0,10-0,05$; Total $=2-0,05$; silte $=0,05-0,002$; Argila total $<0,002$; argila $\mathrm{H} 2 \mathrm{O}<0,002$

- Com duas frações de areia: grossa $=2-0,25$; Fina $=0,25-0,05$

- Classe de Textura: até $14 \%$ - arenosa; 15 a $24 \%$ - média-arenosa; $25-34 \%$ - média argilosa; $35-57 \%$ - argilosa; $60 \%$ ou superior - muito argilosa

\subsubsection{Análises Mineralógicas}

O difratograma da fração silte dos solos estudados, acusou a ocorrência de minerais feldspatos, plagioclasio e pirofilita, com exceção do Cambissolo Latossólico $(\mathrm{CL})$ que não registrou a presença de plagioclásio (tabela 7). Os minerais foram identificados pelos seus picos: feldspatos $(4,19 ; 4,15 ; 4,11$; 3,$77 ; 3,67 ; 3,65 ; 3,42 ; 3,27 ; 2,92$ e $\left.2,52 \mathrm{~A}^{\circ}\right)$; plagioclásio $(3,20 ; 3,18 ; 2,86 ; 1,96 \mathrm{e}$ $\left.1,95 A^{\circ}\right)$ e pirofilite $(2,44 ; 2,42 ; 2,26 ; 2,25 ; 2,23 ; 2,22 ; 2,21 ; 2,15 ; 2,11 ; 1,80 ; 1,66$ e $1,65 \mathrm{~A}^{\circ}$ ) (Figuras $1,2,3$ e 4 ). Os picos $4,19 \mathrm{~A}^{\circ}, 4,15 \mathrm{~A}^{\circ}, 4,11 \mathrm{~A}^{\circ}$ e $3,27 \mathrm{~A}^{\circ}$ evidenciam uma nitida dominância dos minerais de feldspatos.

Vale ressaltar serem os feldspatos fonte de potássio, plagioclásio fonte de sódio e cálcio e a pirofilita fonte de alumínio. 


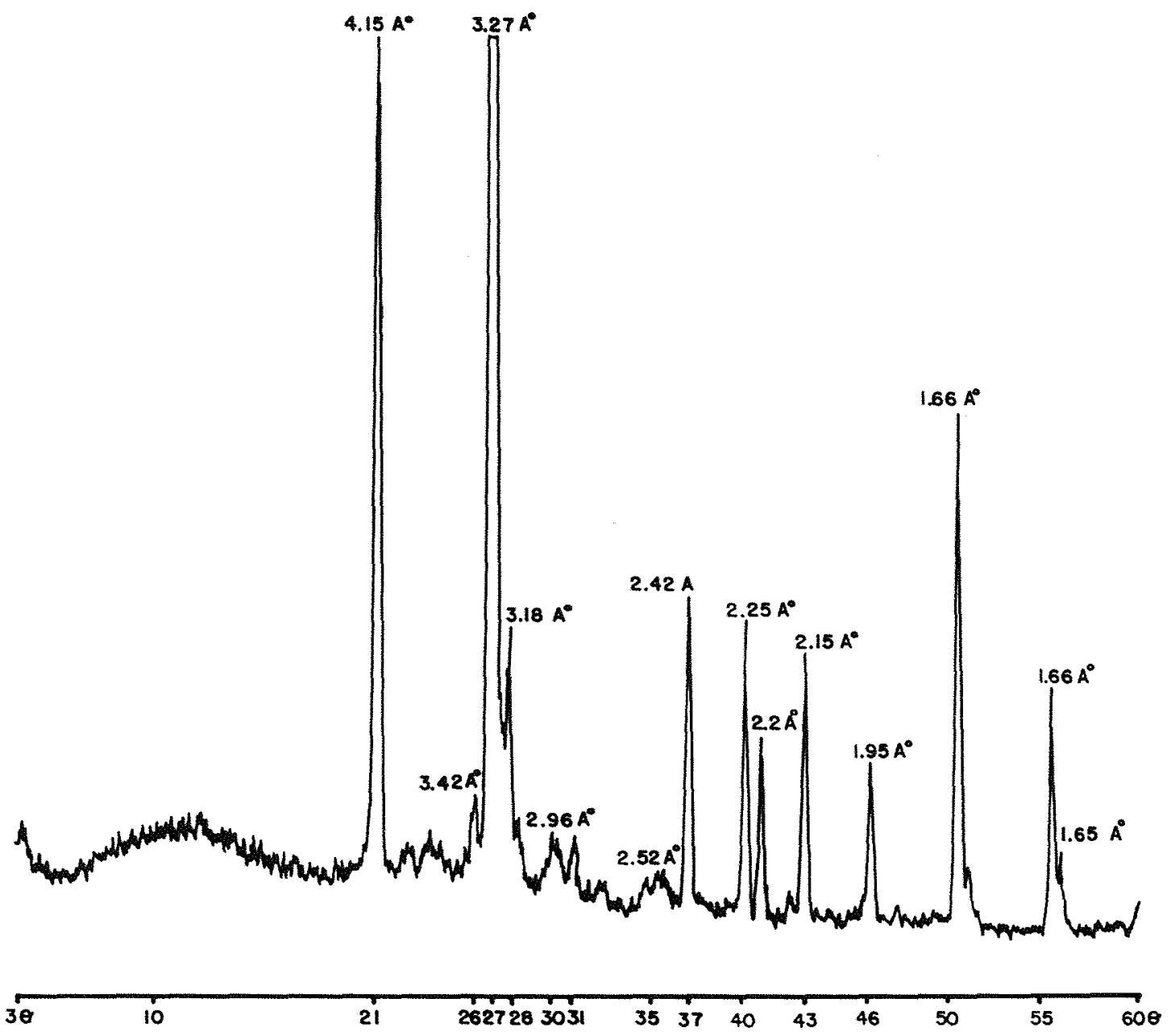

Figura 1. Difratograma de raio $X$ da fração silte do Latossolo Vermelho Amarelo 


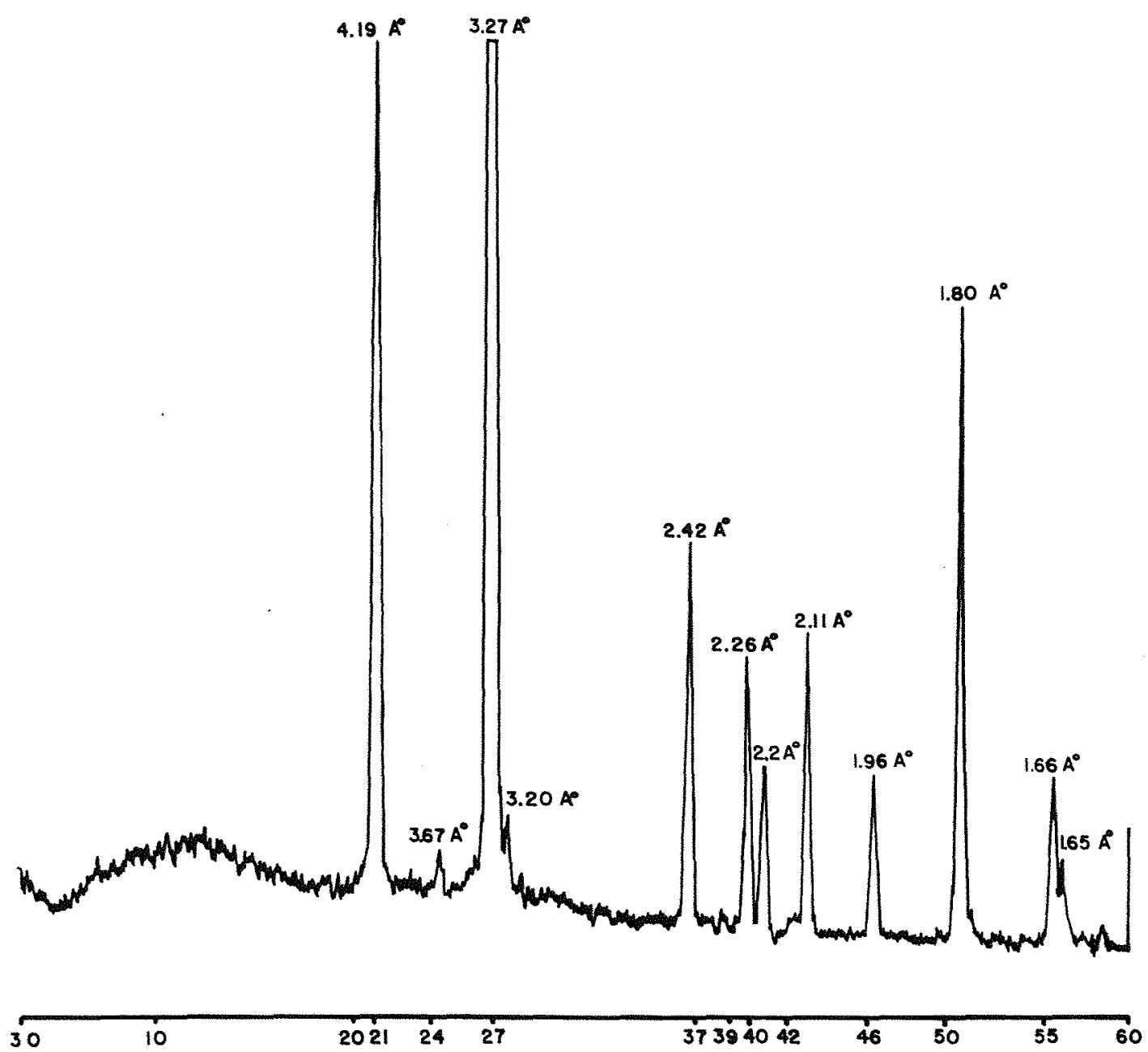

Figura 2. Difratograma de raio $X$ da fração silte do Latossolo Amarelo 


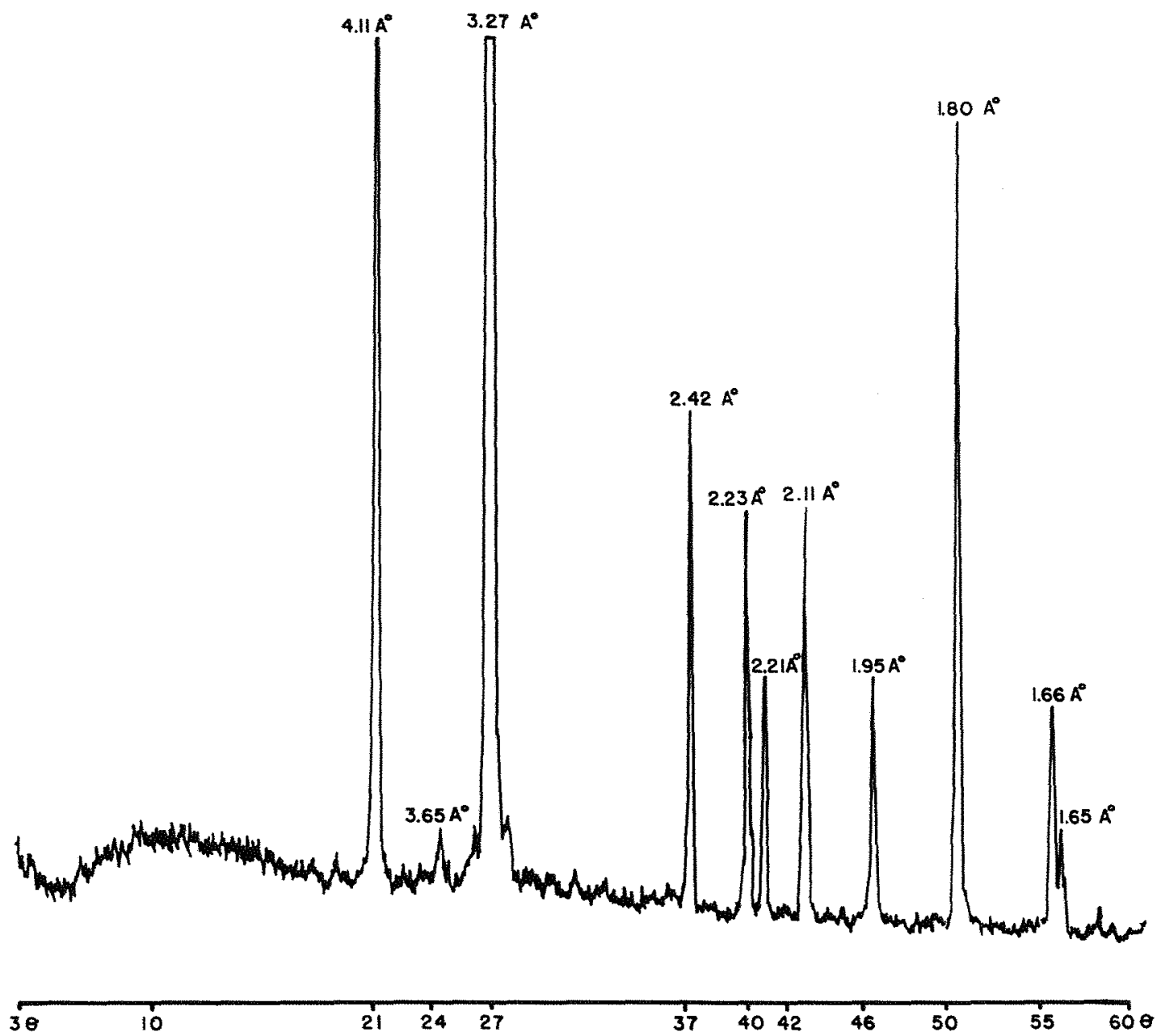

Figura 3. Difratograma de raio $X$ da fração silte do Cambissolo Vértico 


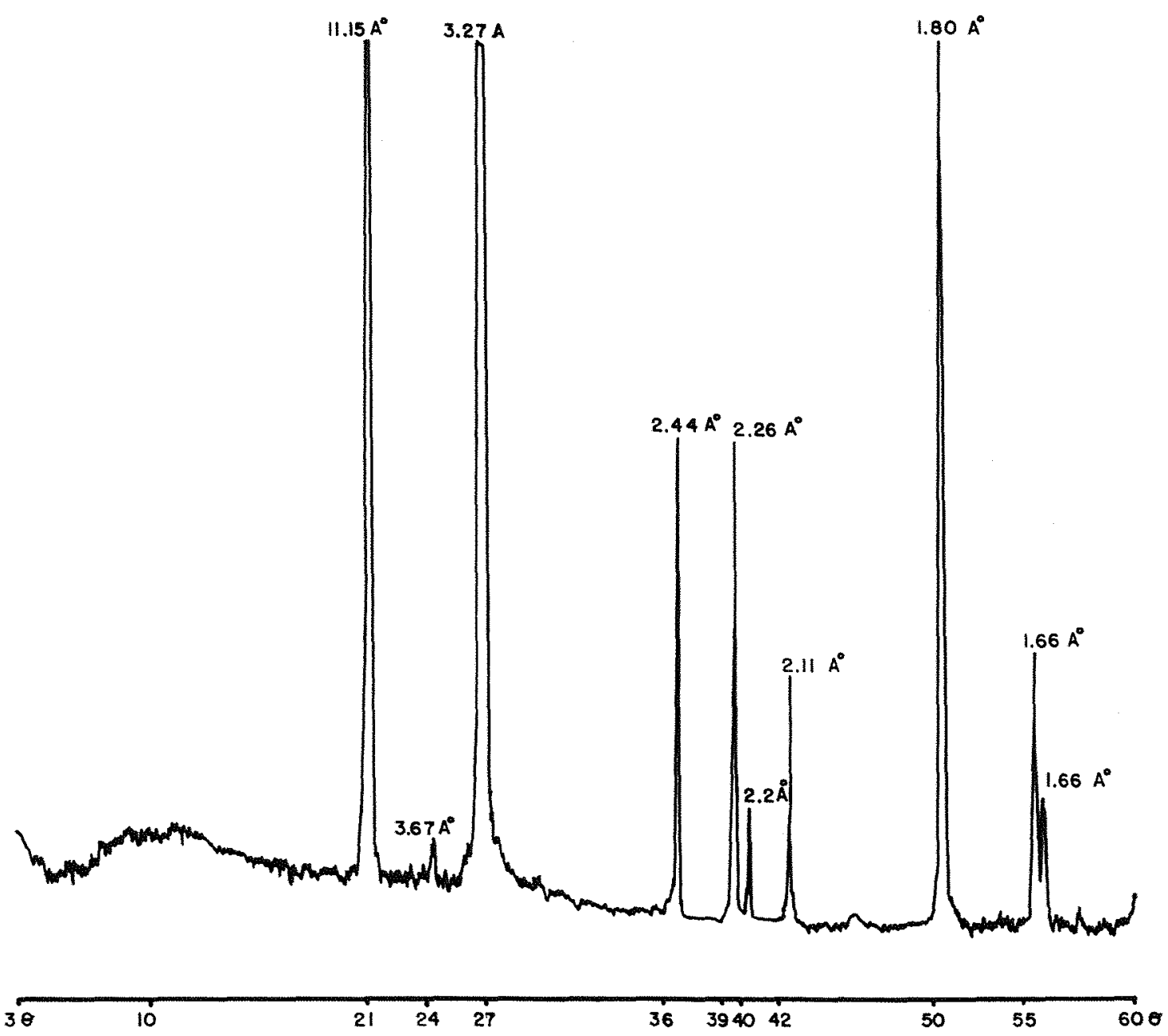

Figura 4. Difratograma de raio $X$ da fração silte do Cambissolo Latossólico 
Tabela 7. Composição mineralógica qualitativa das amostras do LVA, LA, CV e CL estudados

\begin{tabular}{ccccc}
\hline & & & SOLO & \\
Minerais & LVA & LA & CV & CL \\
\cline { 2 - 5 } Silte & Feldspato & Feldspato & Feldspato & Feldspato \\
& Plagioclásio & Plagioclásio & Plagioclásio & Pirofilita \\
& Pirofilita & Pirofilita & Pirofilita & \\
\hline Argila & Caulinita & Caulinita & Montmorilonita & Caulinita \\
& Vermiculita & Vermiculita & Vermiculita & Vermiculita \\
& Mica & Mica & Mica & Mica \\
& Gibbsita & Gibbsita & Caulinita & Gibbsita \\
& Quartzo & Quartzo & Quartzo & Quartzo \\
\hline
\end{tabular}

Os feldspatos e os plagioclásios geram os produtos:

1. Bases solúveis $\mathrm{KOH}, \mathrm{Ca}(\mathrm{OH})_{2}, \mathrm{NaOH}$ que, ou se perdem por lixiviação ou são absorvidos pelos vegetais, ou são adsorvidos ao complexo do solo.

2. Bases insolúveis, $\mathrm{Ca}(\mathrm{OH})_{2}$, formando $\mathrm{CaCO}_{3}$.

3. Forma ácido silicico, que se perde na drenagem, se o meio for alcalino, ou então, ai permanece, se este for ácido.

Apesar da pirofilita ser fonte de alumínio, provavelmente a não presença de alumínio nas análises químicas dos solos, seja em função do pH dos solos encontra-se em torno de 7,0 onde não ocorre aluminio solúvel.

REZENDE (1982) chama atenção que é na fração grosseira, silte e areia, que se encontra os minerais capazes de fornecer, após intemperização, nutrientes para as plantas. Em razão disto, pela análise mineralógica da fração silte, pode-se, pelos minerais encontrados, ter uma boa idéia do potencial do solo em fornecimento de nutrientes.

Os difratogramas da fração argila da amostra do Latossolo Vermelho Amarelo (LVA), Latossolo Amarelo (LA) e Latossolo Cambissólico (CL) apresentam semelhança em termos qualitativos (tabela 7). Possivelmente a 
caulinita é o mineral predominante em termos quantitativos, pois apresentou os maiores picos (figuras 5, 6 e 8). No difratograma do Cambissolo Vértico (CV) e montmorilonita apareceu com os maiores picos, o que provavelmente indica sua predominância (figura 7), não aparecendo neste solo a gibbsita (tabela 7). Os picos que identificaram os minerais foram: Caulinita $(7,13 ; 7,08 ; 4,56 ; 4,43 ; 3,56$; $\left.3,53 \mathrm{~A}^{\circ}\right)$, montmorilonita $\left(17,0\right.$ e $\left.12,1 \mathrm{~A}^{\circ}\right)$, vermiculita $(14,2 ; 14,0 ; 13,8 ; 13,1$ e 12,6 $\left.A^{\circ}\right)$, mica $\left(10,5 ; 10,4 ; 10,0 ; 9,82 ; 9,72 ; 5,0 ; 4,98 ; 4,92 A^{\circ}\right)$, gibbsita $(4,90 ; 4,87$; 4,$\left.84 ; 4,43 ; 4,39 ; 4,37 ; 4,34 A^{\circ}\right)$, quartzo $\left(4,23 ; 4,21 A^{\circ}\right)$.

Trabalhando com solos descarbonatados do calcário bambui da região de Irecê, SANTOS (1976) constatou que estas rochas, quando dissolvidas, liberam uma quantidade importante de argilo-minerais 2:1, o que explica a presença da montmorilonita, vermiculita e mica no LVA e LA que são derivados do mesmo material calcário. Afirma ainda o autor que a atual mineralogia das argilas destes solos é função do processo evolutivo (monossialitização), aos quais estes solos foram submetidos. Segundo FORTUNATO (1982), em função dos Cambissolos apresentarem uma pedogênese mais incipiente, tem a sua mineralogia muito mais próxima dos argilo minerais contidos no calcário. 

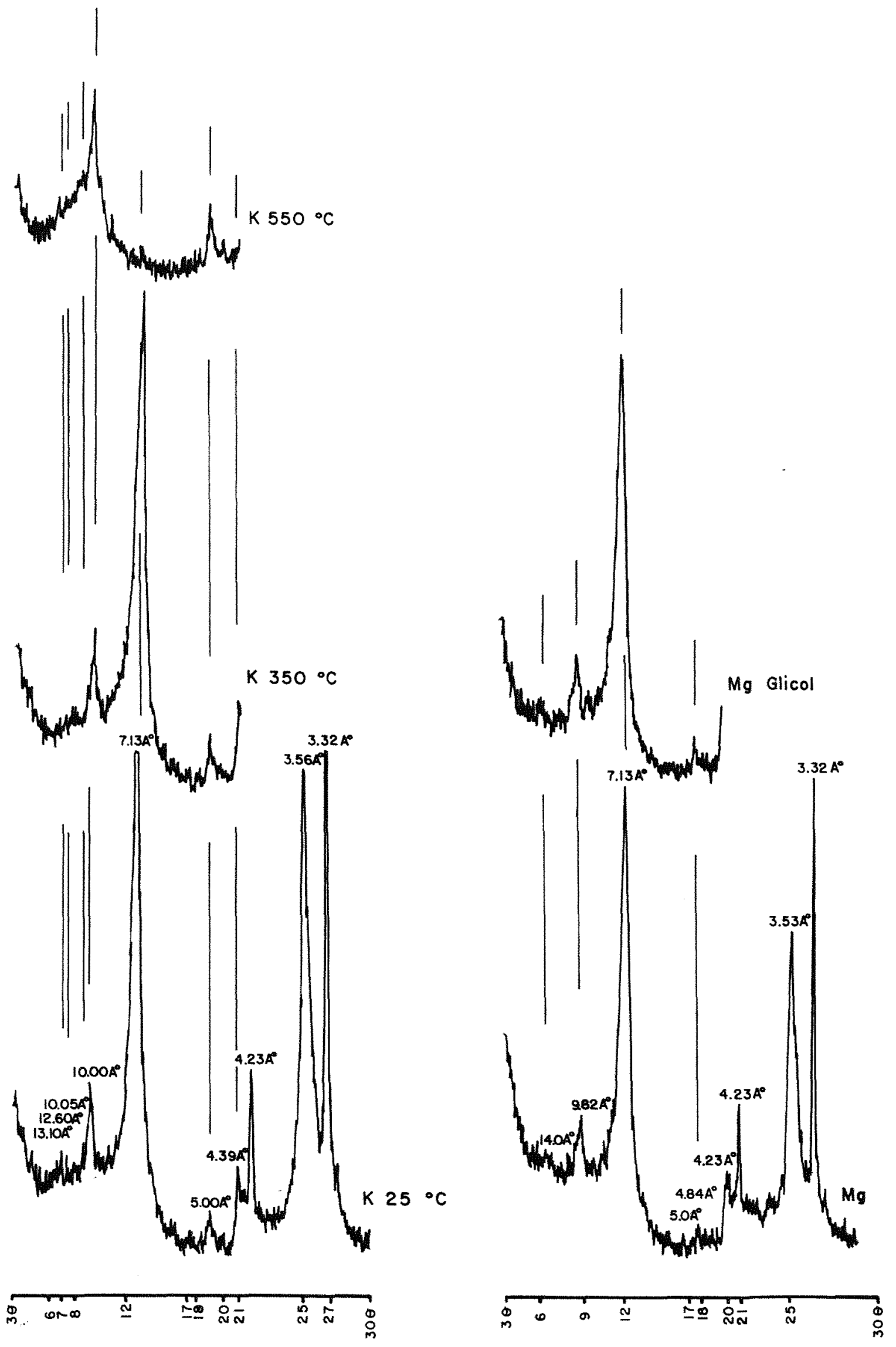

Figura 5. Difratograma de raio $X$ da fração argila do Latossolo Vermelho Amarelo 

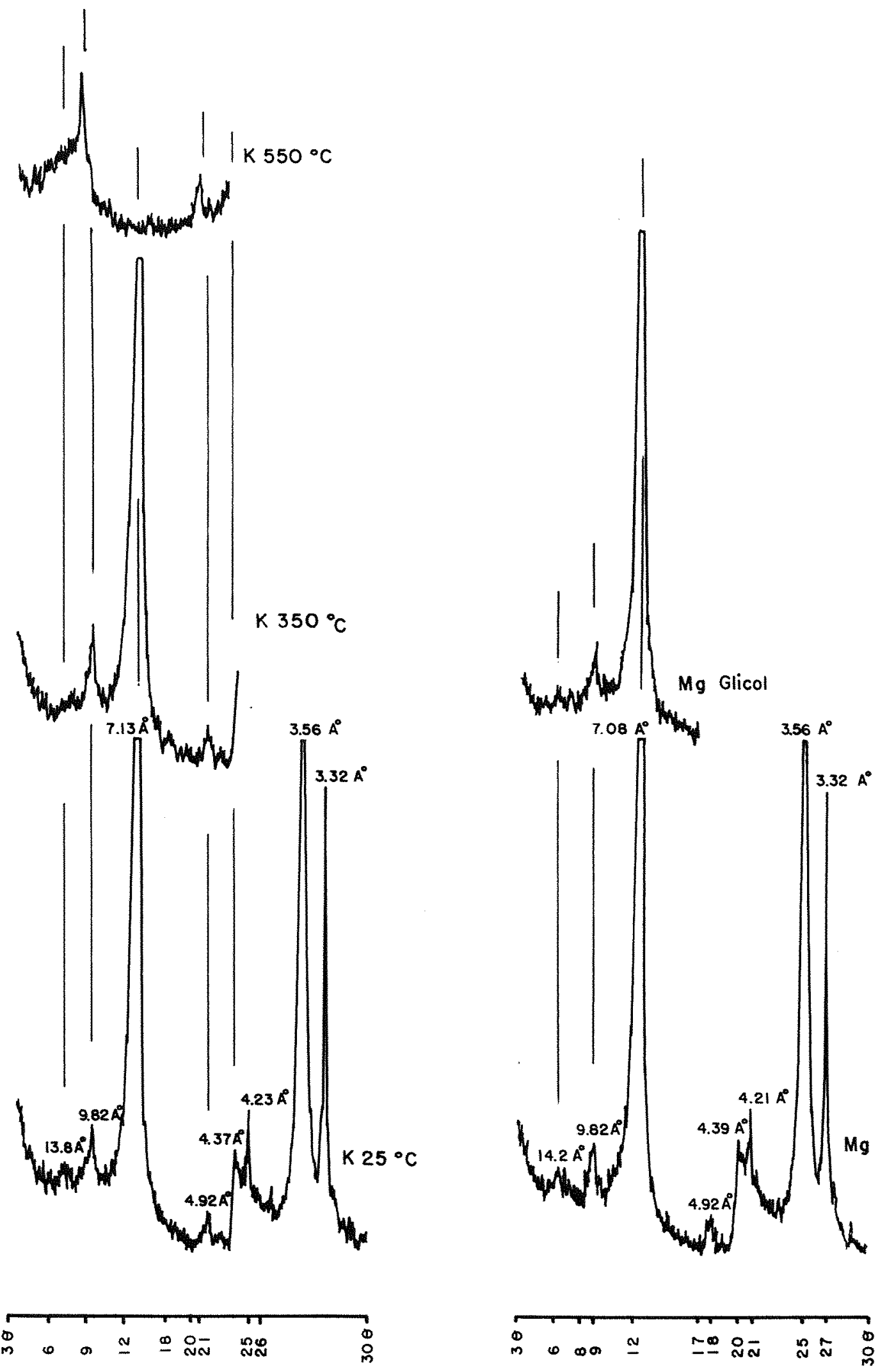

Figura 6. Difratograma de raio $X$ da fração argila do Latossolo Amarelo 

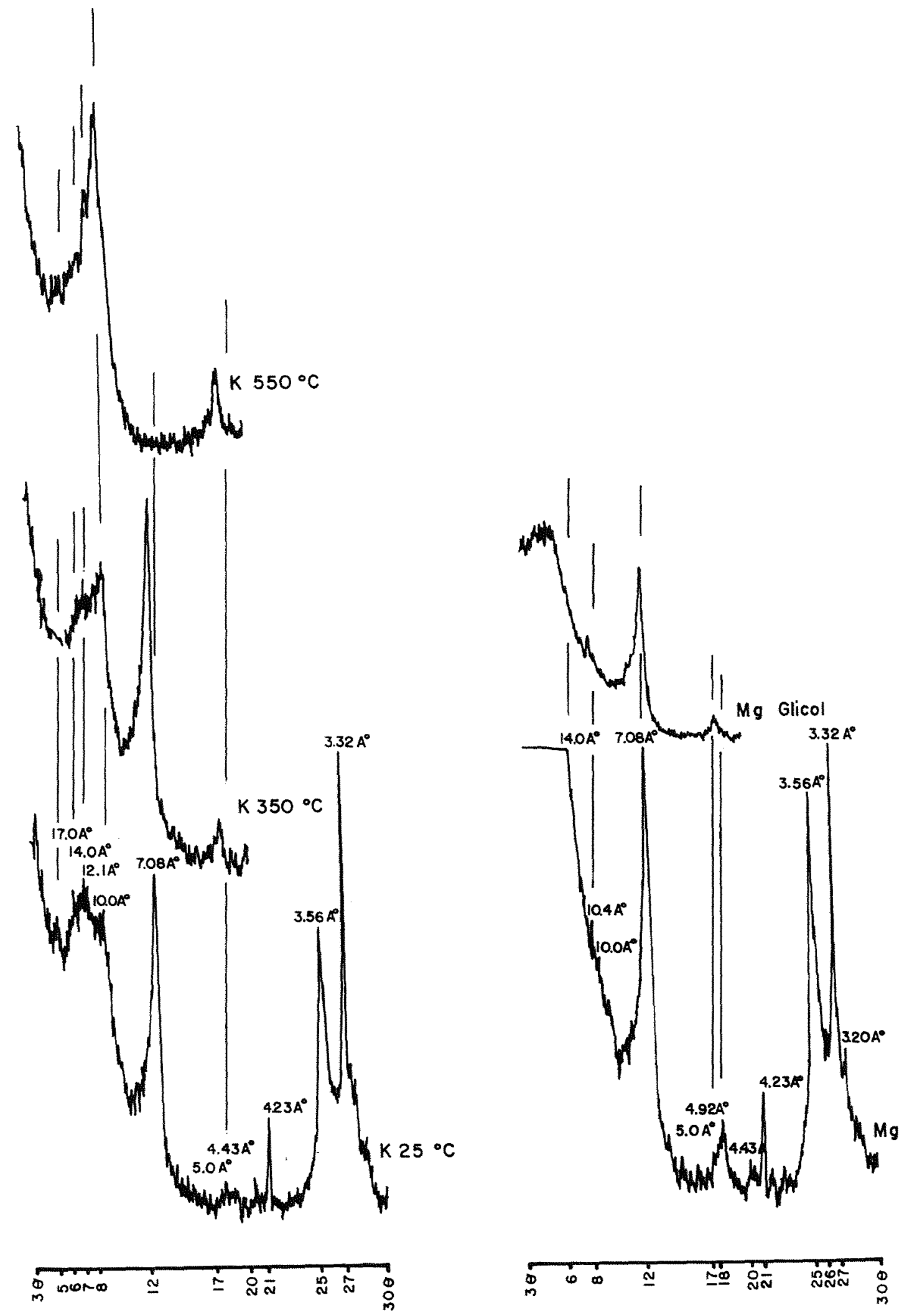

Figura 7. Difratograma de raio $X$ da fração argila do Cambissolo Vértico 

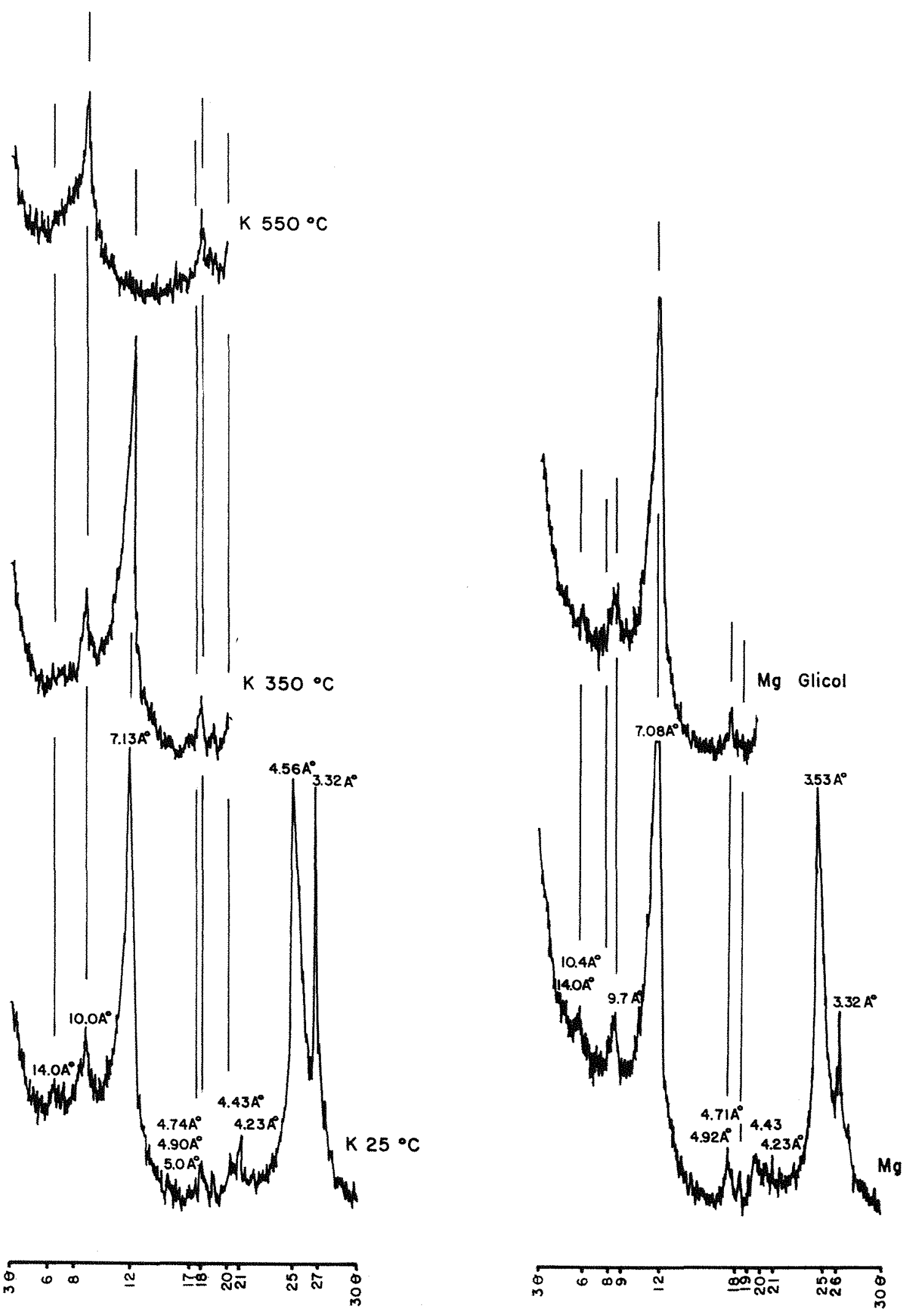

Figura 8. Difratograma de raio $X$ da fração argila do Cambissolo Latossólico 


\subsubsection{Análises Químicas}

Seguindo a Recomendação de Adubação e Calagem para o Estado de São Paulo (1985), observa-se na tabela 8 que, para a determinação do pH em $\mathrm{CaCl}_{2}$, os solos LVA, LA, CV e CL apresentaram acidez muito baixa. No $\mathrm{pH}$ em água segundo a Comissão Estadual de Fertilidade do Solo do Estado da Bahia (1989), o CL apresenta uma acidez fraca, o LA alcalinidade fraca, o LVA alcalinidade média e o CV uma alcalinidade elevada. Os valores de $\triangle \mathrm{pH}$ de ambos os solos são negativos, o que sugere solos mais novos, onde há predominância de carga elétrica líquida negativa.

Os teores de matéria orgânica encontrados no LVA, LA e CL são considerados médios, e o valor encontrado no $\mathrm{CV}$ é classificado como alto. Este valor mais alto, possivelmente, é favorecido pela textura muito argila (com $64 \%$ de argila total) e segundo EVANS \& RUSSEL (1959) pela ação estabilizante provocada principalmente pelo maior teor de cálcio encontrado no Cambissolo Vértico.

Os valores de fósforo extraídos pelo extrator resina (tabela 8) são considerados baixo no $C V$, médio no $L A$ e alto no LVA e CL. Segundo THOMAS \& PEASLEE (1973), para o extrator Mehlich o fósforo disponivel é médio no LA e considerado alto para o LVA, CV e CL; no extrator Olsen os valores são altos para todos os solos, todavia para extrator Bray 1 os teores são considerados baixos para os solos LVA, LA e CV e médio para o $\mathrm{CL}$. Vale ressaltar, que o Cambissolo Vértico (CV), apareceu como teores baixo de fósforo para o extrator resina e Bray 1 e como teores altos para os extratores Mehlich e Olsen, segundo THOMAS \& PEASLEE (1977) e OLSEN \& KHASAWNEW (1980) isto acontece em virtude da ação dos diferentes extratores sobre as formas de fósforo presentes nos solos. Através da tabela 7 verifica-se que na fração argila o $\mathrm{CV}$ foi o único solo a não acusar a presença da gibbsita, $\mathrm{Al}(\mathrm{OH})_{3}$, que tem um alto poder adsorvente, o que também pode ter influenciado na ação dos extratores. 
Tabela 8. Caracteristicas químicas das amostras dos solos estudados

\begin{tabular}{|c|c|c|c|c|}
\hline \multirow[t]{2}{*}{ Caracteristicas Químicas } & \multicolumn{4}{|c|}{ Solos } \\
\hline & LVA & $\mathrm{LA}$ & $\mathrm{CV}$ & $\mathrm{CL}$ \\
\hline pH em água $(1: 2,5)$ & 7,9 & 7,3 & 8,2 & 6,7 \\
\hline $\mathrm{pH}$ em KCl $(1: 2,5)$ & 6,9 & 6,5 & 7,2 & 5,4 \\
\hline $\mathrm{pH} \mathrm{em} \mathrm{CaCl}(1: 2,5)$ & 6,5 & 6,4 & 7,3 & 5,7 \\
\hline$\Delta \mathrm{pH}$ & $-1,0$ & $-0,8$ & $-1,0$ & $-1,3$ \\
\hline $\mathrm{MO}\left(\mathrm{g} / \mathrm{dm}^{3}\right)^{(t)}$ & 25,0 & 20,7 & 31,7 & 23,0 \\
\hline $\left.\mathrm{MO}) \mathrm{g} / \mathrm{dm}^{3}\right)^{(2)}$ & 25,2 & 20,6 & 34,9 & 24,3 \\
\hline P-resina $\left(\mathrm{mg} / \mathrm{dm}^{3}\right)$ & 46 & 30 & 8 & 52 \\
\hline P-Mehlich $\left(\mathrm{mg} / \mathrm{dm}^{3}\right)$ & 60 & 36 & 47 & 59 \\
\hline P-Olsen $\left(\mathrm{mg} / \mathrm{dm}^{3}\right)$ & 47 & 34 & 13 & 79 \\
\hline P-Bray $1\left(\mathrm{mg} / \mathrm{dm}^{3}\right)$ & 14 & 11 & 1 & 19 \\
\hline $\mathrm{S}\left(\mathrm{mg} / \mathrm{dm}^{3}\right)^{(3)}$ & 14 & 14 & 10 & 8 \\
\hline $\mathrm{K}$-resina $\left(\mathrm{mmol}_{\mathrm{C}} / \mathrm{dm}^{3}\right)^{(4)}$ & 17,00 & 10,40 & 2,80 & 3,70 \\
\hline K-Mehlich $\left(\mathrm{mmol}_{\mathrm{d}} / \mathrm{dm}^{3}\right)$ & 12,67 & 8,09 & 2,90 & 2,92 \\
\hline Na-Mehlich $\left(\mathrm{mmol}_{/} / \mathrm{dm}^{3}\right)^{(5)}$ & 1,1 & 0,6 & 1,5 & 0,6 \\
\hline Ca-resina $\left(\mathrm{mmol}_{d} / \mathrm{dm}^{3}\right)^{(6)}$ & 84,70 & 67,30 & 366,70 & 101,70 \\
\hline Ca-Mehlich $\left(\mathrm{mmol}_{\mathrm{c}} / \mathrm{dm}^{3}\right)$ & 60,36 & 38,86 & 258,26 & 82,66 \\
\hline $\mathrm{Mg}$-resina $\left(\mathrm{mmol}_{\mathrm{d}} / \mathrm{dm}^{3}\right)^{(\zeta)}$ & 26,00 & 13,00 & 17,60 & 20,00 \\
\hline Mg-Mehlich $\left(\mathrm{mmol}_{c} / \mathrm{dm}^{3}\right)$ & 28,70 & 15,56 & 27,23 & 22,13 \\
\hline $\mathrm{Al}\left(\mathrm{mmol}_{\mathrm{c}} / \mathrm{dm}^{3}\right)^{(8)}$ & 0,00 & 0,00 & 0,00 & 0,00 \\
\hline $\mathrm{H}^{+}+\mathrm{Al}^{3+}\left(\mathrm{mmol}_{\mathrm{c}} / \mathrm{dm}^{3}\right)^{(\theta)}$ & 12 & 14 & 10 & 29 \\
\hline $\mathrm{CaCO}_{3}$ (equivalente $\left.\%\right)^{(10)}$ & 0,99 & 0,77 & 2,40 & 0,91 \\
\hline $\mathrm{S}\left(\mathrm{mmol}_{\mathrm{d}} / \mathrm{dm}^{3}\right)^{(11)}$ & 128,8 & 91,3 & 388,6 & 126,00 \\
\hline $\mathrm{T}\left(\mathrm{mmol}_{\mathrm{c}} / \mathrm{dm}^{3}\right)^{(12)}$ & 140,8 & 105,3 & 398,6 & 155,00 \\
\hline$V(\%)^{(13)}$ & 91,48 & 86,70 & 97,49 & 81,29 \\
\hline$m(\%)^{(14)}$ & 0 & 0 & 0 & 0 \\
\hline $\mathrm{SiO}_{2}(\%)$ & 13,8 & 12,7 & 17,6 & 17,4 \\
\hline $\mathrm{Al}_{2} \mathrm{O}_{3}(\%)$ & 12,0 & 11,5 & 11,8 & 14,6 \\
\hline $\mathrm{Fe}_{2} \mathrm{O}_{3}(\%)$ & 4,6 & 3,0 & 6,3 & 6,4 \\
\hline $\mathrm{TiO}_{2}(\%)$ & 0,29 & 0,31 & 0,27 & 0,39 \\
\hline $\mathrm{Ki}^{(15)}$ & 1,95 & 1,88 & 2,53 & 2,03 \\
\hline $\mathrm{Kr}^{(16)}$ & 1,57 & 1,61 & 1,89 & 1,58 \\
\hline $\begin{array}{l}\text { (1) Método colorimétrico (Quag } \\
\text { (2) Método combustão por via } \\
\text { (3) Extrator } \mathrm{NH}_{4} \mathrm{OAC} 0,5 \mathrm{~N} \text { em } \\
\text { (8) Alumínio trocável - extrator } \\
\text { (9) Acidez potencial - solução ta } \\
\text { (10) Neutralização com } \mathrm{HCl} \text { (RIC } \\
\text { (11) Soma de bases trocáveis ( } 4 \\
\text { (12) Capacidade de troca de cáti } \\
\text { (13) Saturação de bases ( } \mathrm{S} / \mathrm{T} .10 \\
\text { (14) Saturação de aluminio }\left(\mathrm{Al}^{3+}\right. \\
\text { (15) Relação molecular } \mathrm{SiO}_{2} / \mathrm{Al}_{2} \\
\text { (16) Relação molecular } \mathrm{SiO}_{2} /\left(\mathrm{Al}_{2}\right.\end{array}$ & $\begin{array}{l}\text { e Raij, } 19 \\
\text { do "Car! } \\
\mathrm{C} 0,25 \mathrm{~N} \\
1 \mathrm{~N}(\mathrm{RAIJ} \\
\text { âo SMP ( } \\
\mathrm{RDS}, 195 \\
6+7) \\
\left(\mathrm{S}+\mathrm{H}+\mathrm{Al} \mathrm{Al}^{3+}\right. \\
\left.\left.\mathrm{AN}^{3+}\right) \cdot 100\right) \\
\left.\mathrm{Fe}_{2} \mathrm{O}_{3}\right)\end{array}$ & al., 1987) & 9) & off KG. \\
\hline
\end{tabular}


Os valores de enxofre disponivel (tabela 8) do LVA e LA são ligeiramente superiores aos encontrados no $\mathrm{CV}$ e $\mathrm{CL}$, e em ambos os solos superiores ao nivel crítico encontrado por KILMER \& NEARPASS (1960) que foi de $10 \mathrm{mg} / \mathrm{dm}^{3}$ usando o extrator $\mathrm{NaHCO}_{3} \mathrm{pH} \mathrm{8,5}$ para solos calcários dos Estados Unidos, tendo como planta indicadora o algodoeiro, como também ao nivel critico de $2 \mathrm{mg} / \mathrm{dm}^{3}$ encontrado por VITTI et al. (1982) em solos do Estado de São Paulo, usando como extrator $\mathrm{NH}_{4} \mathrm{OAC} 0,5 \mathrm{~N}$ em $\mathrm{HOAC} 0,25 \mathrm{~N}$ e o feijoeiro como planta indicadora.

Os valores da soma de bases (S) como pode visualizar-se na tabela 8 encontram-se altos em todos os solos. Os teores de potássio trocável são considerados muito altos para o LVA e LA, alto para o $\mathrm{CL}$ e médio para o $\mathrm{CV}$. Cálcio e magnésio trocáveis podem ser considerados muito alto $\mathrm{e}$ alto respectivamente para todos os solos. As quantidades de sódio do solo LVA e CV são o dobro do LA e CL e para ambos os solos os valores muito próximos dos encontrados por CUNHA (1992) nos mesmos tipos de solos. As percentagens de potássio, cálcio, magnésio e sódio respectivamente na soma de bases para o LVA são: 13,$20 ; 65,76 ; 20,19$ e $0,85 \%$; no LA 11,$39 ; 73,71 ; 14,24$ e $0,55 \%$; no CV 0,72 ; 94,$36 ; 4,53$ e $0,39 \%$ e para $C L 2,94 ; 80,71 ; 15,87$ e $0,48 \%$. Em todos os solos observa-se no equilíbrio de bases uma predominância de $\mathrm{Ca}^{++}>\mathrm{Mg}^{++}>\mathrm{K}^{+}>\mathrm{Na}^{+}$. Segundo BOYER (1971), nos solos relativamente bem dotados em bases, carências de potássio aparecem com o teor de $\mathrm{K}$ inferior a $2 \%$ da soma das bases trocáveis, nesta situação, apenas no CV apresenta a percentagem de potássio abaixo de $2 \%$ da soma de bases, todavia, o teor de $2,8 \mathrm{mmol} / \mathrm{dm}^{3}$ de $\mathrm{K}$ trocável no CV esta acima do nível crítico de potássio no solo de $2,0 \mathrm{mmol} / \mathrm{dm}^{3}$ tendo como planta indicadora o feijoeiro (van RAIJ, 1974).

A saturação de bases segundo a Recomendação de Adubação e Calagem para o Estado de São Paulo (1985), é considerada alta para os solos LA e CL e muito alta para LVA e CV.

Pela tabela 8 verifica-se que não foi detectado alumínio trocável pela metodologia empregada nos solos estudados, o que induz a uma nula saturação de alumínio, reflexo do alto teor de bases trocáveis.

A acidez potencial foi maior no CL que nos demais solos, tabela 8 , mostrando com isto, a maior presença de cargas dependentes de $\mathrm{pH}$. 
Os valores da CTC ou valor $T$ são considerados altos para todos os solos, apresentando as seguintes percentagens de potássio, cálcio, magnésio, sódio e $\mathrm{H}+\mathrm{Al}$ respectivamente: LVA - 12,07;60,16;18,47;0,78 e 8,52\%. LA - 9,88; 63,$91 ; 12,35 ; 0,57$ e $13,30 \%$. CV - 0,70; 92,$00 ; 4,42 ; 0,38$ e $2,51 \%, C L-2,39$; 65,$61 ; 12,90 ; 0,39$ e $18,71 \%$. Observa-se no equilíbrio de bases para o LVA uma predominância de: $\mathrm{Ca}^{++}>\mathrm{Mg}^{++}>\mathrm{K}^{+}>\left(\mathrm{H}^{+}+\mathrm{Al}^{+++}\right)>\mathrm{Na}$; para o $\mathrm{LA}$ e $\mathrm{CL} \mathrm{Ca}{ }^{++}>$ $\left(\mathrm{H}^{+}+\mathrm{Al}^{+++}\right)>\mathrm{Mg}^{++}>\mathrm{K}^{+}>\mathrm{Na}^{+}$e no $\mathrm{CV} \mathrm{Ca}{ }^{++}>\mathrm{Mg}^{++}>\left(\mathrm{H}^{+}+\mathrm{Al}^{+++}\right)>\mathrm{K}^{+}>\mathrm{Na}^{+}$.

A participação efetiva de $\left(\mathrm{H}^{+}+\mathrm{Al}^{+++}\right)$na $\mathrm{CTC}$ sugere que as cargas negativas estão sendo ocupadas por ions de hidrogênio ligados covalentemente, mostrando o potencial de cargas dependentes de $\mathrm{pH}$ destes solos.

Os teores de carbonato de cálcio são baixos e o solo CV que apresenta o maior teor, é também o que possui $94,36 \%$ de cálcio na soma de bases e $92,00 \%$ na CTC.

A relação molecular silica/alumina (Ki) foi estabelecida para avaliar o grau de evolução dos solos, bem como o tipo de alteração que foi submetido (tabela 8). Pelos valores de Ki, de acordo com VERDADE (1975), pode-se inferir que o tipo de argila predominante no Latossolo Vermelho Amarelo (LVA), Latossolo Amarelo (LA) e Cambissolo Latossólico (CL) é do tipo 1:1 (caulinita) com prsença de hidróxido de alumínio livre (gibbsita), e no Cambissolo Vértico do tipo $2: 1$ sem presença de gibbsita. A relação molecular sílica/alumina (Ki) serão tanto menores quanto mais avançado for o estágio, de meteorização do material. Vale ressaltar, que as conclusões tiradas da relação $\mathrm{Ki}$ estão de acordo com as conclusões extraídas do difratograma de raio- $X$ (tabela 7 ) e (figuras $11,12,13$ e 14).

Pela tabela 9 observa-se que os extratores comportaram-se diferentemente quanto à capacidade de extrair os micronutrientes do solo. 0 extrator Mehlich extraiu mais boro, ferro, manganês e zinco e menos cobre. Os maiores valores extraídos pelo Mehlich, podem ser explicados por ser o extrator ácido suficientemente énérgico, acidificando o solo durante o período de agitação, provocando a solubilização dos micronutrientes (BATAGLIA \& RAIJ, 1989).

CAMARGO et al. (1982) verificaram que o extrator DTPA discriminava o efeito do $\mathrm{pH}$ sobre a disponibilidade de micronutrientes no solo, enquanto o extrator Mehlich não conseguia discriminar o efeito da elevação do $\mathrm{pH}$ para cobre, ferro, manganês e zinco. Além deste trabalho, outros autores 
encontraram vantagens do extrator DTPA (solução complexante) sobre o extrator Mehlich (solução ácida) (MURAOKA et al., 1983 a, b; RIBEIRO \& TUCUMANGO SARABIA, 1984). A literatura sugere portanto, ser o extrator DTPA o mais conveniente para os micronutrientes acima citados.

BATAGLIA \& RAIJ (1989), em testes conduzidos com B, mostraram que os coeficientes de correlação entre os teores no solo e a absorção pela planta de girassol foram maiores para água quente e solução de $\mathrm{CaCl}_{2} \quad 0,01 \mathrm{M}$ a quente do que para o extrator Mehlich, o que também sugere serem os resultados de boro extraido com $\mathrm{CaCl}_{2}$ os mais adequados neste caso.

Tabela 9. Resultados de análise química de micronutrientes $\left(\mathrm{mg} / \mathrm{dm}^{3}\right)$ das amostras dos solos estudados

\begin{tabular}{|c|c|c|c|c|}
\hline \multirow[t]{2}{*}{ Características Químicas } & \multicolumn{4}{|c|}{ Solos } \\
\hline & LVA & LA & $\mathrm{CV}$ & $C L$ \\
\hline$B^{(1)}$ & 1,82 & 1,34 & 2,37 & 1,04 \\
\hline$B^{(2)}$ & 0,60 & 0,57 & 0,45 & 0,40 \\
\hline $\mathrm{Cu}^{(1)}$ & 0,90 & 0,50 & 0,43 & 1,13 \\
\hline $\mathrm{Cu}^{(3)}$ & 1,16 & 0,87 & 1,07 & 1,45 \\
\hline $\mathrm{Fe}^{(1)}$ & 9 & 6 & 8 & 12 \\
\hline $\mathrm{Fe}^{(3)}$ & 6 & 5 & 7 & 18 \\
\hline $\mathrm{Mn}^{(1)}$ & 231 & 239 & 113 & 77 \\
\hline $\mathrm{Mn}^{(3)}$ & 27 & 31 & 14 & 68 \\
\hline $\mathrm{Zn}{ }^{(1)}$ & 3,53 & 3,43 & 2,13 & 3,90 \\
\hline $\mathrm{Zn}^{(3)}$ & 0,99 & 0,89 & 0,59 & 1,13 \\
\hline
\end{tabular}

(1,) extrator $-\mathrm{HCl} \quad 0,05 \mathrm{~N}+\mathrm{H}_{2} \mathrm{SO}_{4} 0,25 \mathrm{~N}$

(2) - extrator - $\mathrm{CaCl}_{2} 2 \mathrm{H}_{2} \mathrm{O} 0,1 \%$

(3) extrator DTPA (ácido dietilenotriaminopentacético) 


\subsection{Estudo da Relação K/(Ca+Mg) no Solo}

No Latossolo Vermelho Amarelo (LVA) verifica-se o estudo de quatro relações $\mathrm{K} /(\mathrm{Ca}+\mathrm{Mg}$ ), e no Latossolo Amarelo (LA), Cambissolo Vértico (CV) e Cambissolo Latossólico (CL) oito relações em cada solo, sendo as quatro primeiras relações atingidas apenas com a adição de potássio e as quatro últimas com a utilização de potássio e magnésio, provocando com isto, uma mudança na relação Ca/Mg dos solos (tabela 5).

\subsubsection{Produção de Grãos e Matéria Seca, Teores e Conteúdos de $\mathrm{K}, \mathrm{Ca}, \mathrm{Mg}$, nas folhas, e nos Grãos do Feijoeiro em Função das Relações $\mathrm{K} /(\mathrm{Ca}+\mathrm{Mg})$ Aplicadas nos Solos}

\subsubsection{Produção de Grãos e Matéria Seca}

$\mathrm{Na}$ tabela 10, considerando-se o ensaio como um todo, em média, a produção de grãos, matéria seca de: folhas, raízes, caule + ramos, vagem e total, não apresentam diferenças significativas pelo teste de Tukey, ao nivel de $5 \%$ de probabilidade.

Para o Latossolo Vermelho Amarelo observa-se uma ligeira tendência de aumento na produção de grãos na relação $1 / 11,05$, diminuindo com o aumento da relação $\mathrm{K} /(\mathrm{Ca}+\mathrm{Mg})$ no solo. Ainda neste mesmo solo, na mais alta relação $1 / 6,86$, ocorreu a maior produção de matéria seca total, que diferiu na produção da relação $1 / 12,11$ pelo teste de Tukey ao nível de $5 \%$ de probabilidade.

Pela tabela 10 vê-se também no Latossolo Amarelo, apesar de não apresentar diferenças significativas, um aumento na produção de matéria seca total nas quatro últimas relações $\mathrm{K} /(\mathrm{Ca}+\mathrm{Mg})(1 / 17,10 ; 1 / 13,59 ; 1 / 12,45 ; 1 / 10,26)$, quando se abaixou a relação entre $\mathrm{Ca}$ e $\mathrm{Mg}$, com adição de magnésio.

No Cambissolo Vértico (tabela 10), a maior produção de grãos ocorreu na relação $\mathrm{K} /(\mathrm{Ca}+\mathrm{Mg}) 1 / 377,51$. originária do solo, vale ressaltar, que este 
solo possui o mais baixo teor de potássio trocável em relação aos demais (tabela 8), sendo calssificado segundo a Recomendação de Adubação e Calagem para o Estado de São Paulo, como teor médio, apresentando $0,72 \%$ de $\mathrm{K}$ na soma de bases, abaixo dos $2 \%$ que segundo BOYER (1971), aparecem carência de K. Todavia, é importante citar que o teor de $2,8 \mathrm{mmol} / \mathrm{dm}^{3}$ de $\mathrm{K}$ trocável encontrado no CV, está acima do nivel crítico de K no solo segundo RAIJ (1974), para cultura do feijoeiro.

Analisando ainda a tabela 10 , percebe-se no Cambissolo Latossólico uma ligeira tendência de aumento na produção de grãos nas quatro últimas relações $\mathrm{K} /(\mathrm{Ca}+\mathrm{Mg})$, onde se abaixou a relação entre $\mathrm{Ca}$ e $\mathrm{Mg}$ com adição de magnésio, cuminando a maior produção de grãos na mais alta relação $\mathrm{K} /(\mathrm{Ca}+\mathrm{Mg})(1 / 41,08)$. 
Tabela 10.Valores médios de produção de grãos e acúmulo de matéria seca nas folhas, raízes, caule + ramos, vagens debulhadas e total ( $g / v a s o)$, para cultura do feijoeiro, em função das relações $\mathrm{K} /(\mathrm{Ca}+\mathrm{Mg}$ ) aplicadas no LVA, LA, CV e CL.

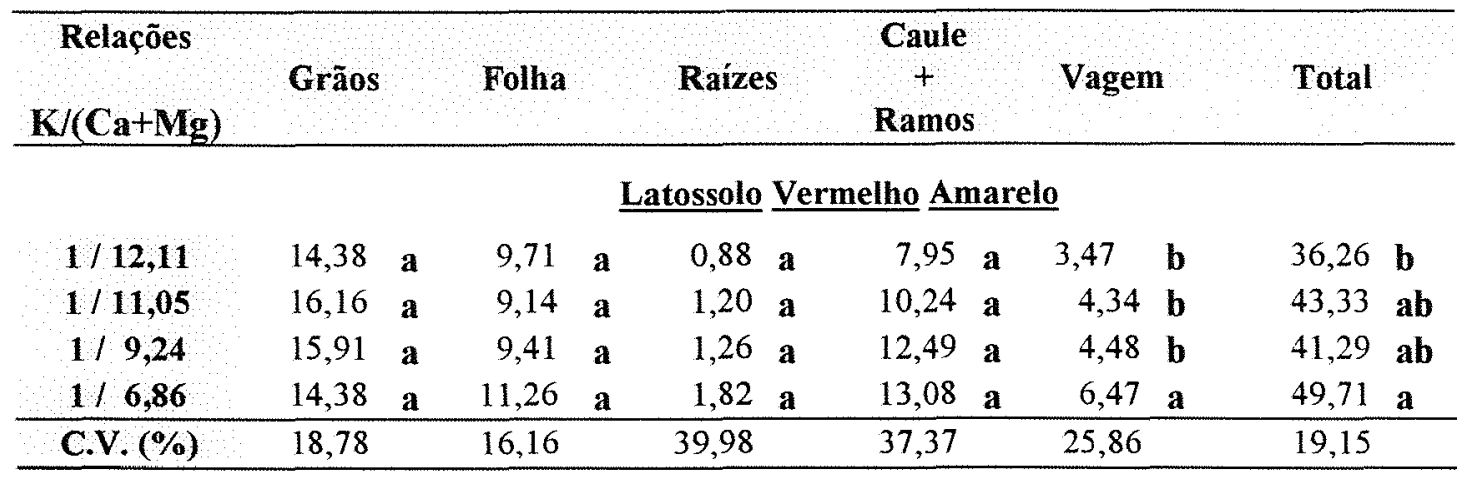

\section{Latossolo Amarelo}

\begin{tabular}{|c|c|c|c|c|c|c|c|c|c|c|c|}
\hline $1 / 13,22$ & 16,20 & $\mathbf{a}$ & 8,82 & $\mathbf{a}$ & 1,48 & $\mathbf{a}$ & 8,63 & $\mathbf{a}$ & 4,67 & $\mathbf{a}$ & 39,80 \\
\hline $1 / 12,25$ & 15,12 & $\mathbf{a}$ & 8,81 & $\mathbf{a}$ & 2,27 & $\mathbf{a}$ & 8,11 & $\mathbf{a}$ & 4,63 & $\mathbf{a}$ & 38,93 \\
\hline $1 / 10,92$ & 14,77 & $\mathbf{a}$ & 9,25 & $\mathbf{a}$ & 1,96 & $\mathbf{a}$ & 10,03 & $\mathbf{a}$ & 4,79 & $\mathbf{a}$ & 40,80 \\
\hline 118,80 & 16,48 & $\mathbf{a}$ & 8,56 & $\mathbf{a}$ & 1,93 & $\mathbf{a}$ & 8,26 & $\mathbf{a}$ & 5,00 & $\mathbf{a}$ & 40,23 \\
\hline $1 / 17,10$ & 14,11 & $\mathbf{a}$ & 8,93 & $\mathbf{a}$ & 1,60 & $\mathbf{a}$ & 8,36 & $\mathbf{a}$ & 3,72 & $\mathbf{a}$ & 36,71 \\
\hline $1 / 13,59$ & 16,04 & $\mathbf{a}$ & 8,88 & $\mathbf{a}$ & 2,58 & $\mathbf{a}$ & 7,54 & $\mathbf{a}$ & 4,65 & $\mathbf{a}$ & 39,69 \\
\hline $1 / 12,45$ & 13,59 & a & 9,29 & $\mathbf{a}$ & 4,81 & $\mathbf{a}$ & 9,51 & $\mathbf{a}$ & 4,55 & $\mathbf{a}$ & 41,75 \\
\hline $1 / 10,26$ & 15,26 & $\mathbf{a}$ & 10,91 & $\mathbf{a}$ & 4,46 & $\mathbf{a}$ & 11,92 & $\mathbf{a}$ & 5,22 & $\mathbf{a}$ & 47,78 \\
\hline C.V. $(\%)$ & 24,14 & & 13,48 & & 57,11 & & 24,65 & & 16,71 & & 16,41 \\
\hline
\end{tabular}

\section{Cambissolo Vértico}

\begin{tabular}{lrlrlrlrlrlll}
$1 / 377,51$ & 16,36 & $\mathbf{a}$ & 11,15 & $\mathbf{a}$ & 2,35 & $\mathbf{a b}$ & 9,22 & $\mathbf{a}$ & 6,22 & $\mathbf{a}$ & 45,30 & $\mathbf{a}$ \\
$\mathbf{1} / \mathbf{2 4 2 , 2 1}$ & 12,58 & $\mathbf{a}$ & 12,54 & $\mathbf{a}$ & 1,84 & $\mathbf{a b}$ & 11,07 & $\mathbf{a}$ & 6,61 & $\mathbf{a}$ & 44,63 & $\mathbf{a}$ \\
$\mathbf{1 / 1 4 7 , 9 9}$ & 10,34 & $\mathbf{a}$ & 9,82 & $\mathbf{a}$ & 1,74 & $\mathbf{b}$ & 8,94 & $\mathbf{a}$ & 4,97 & $\mathbf{a}$ & 35,82 & $\mathbf{a}$ \\
$\mathbf{1} / \mathbf{1 1 2 , 2 7}$ & 12,84 & $\mathbf{a}$ & 8,89 & $\mathbf{a}$ & 1,81 & $\mathbf{a b}$ & 7,77 & $\mathbf{a}$ & 4,96 & $\mathbf{a}$ & 36,27 & $\mathbf{a}$ \\
$\mathbf{1} / \mathbf{4 7 1 , 7 2}$ & 12,36 & $\mathbf{a}$ & 17,14 & $\mathbf{a}$ & 4,30 & $\mathbf{a}$ & 13,03 & $\mathbf{a}$ & 5,92 & $\mathbf{a}$ & 52,74 & $\mathbf{a}$ \\
$\mathbf{1} / \mathbf{2 3 5}, \mathbf{6 5}$ & 10,00 & $\mathbf{a}$ & 12,14 & $\mathbf{a}$ & 2,53 & $\mathbf{a b}$ & 9,31 & $\mathbf{a}$ & 5,22 & $\mathbf{a}$ & 39,19 & $\mathbf{a}$ \\
$\mathbf{1} / \mathbf{2 1 1 , 7 8}$ & 11,87 & $\mathbf{a}$ & 11,46 & $\mathbf{a}$ & 2,64 & $\mathbf{a b}$ & 8,72 & $\mathbf{a}$ & 5,09 & $\mathbf{a}$ & 39,78 & $\mathbf{a}$ \\
$\mathbf{1} / \mathbf{1 0 3 , 2 3}$ & 12,39 & $\mathbf{a}$ & 13,77 & $\mathbf{a}$ & 2,88 & $\mathbf{a b}$ & 9,97 & $\mathbf{a}$ & 6,41 & $\mathbf{a}$ & 45,42 & $\mathbf{a}$ \\
\hline C.V. $(\%)$ & 22,58 & & 24,70 & & 35,74 & 24,19 & 19,67 & & 19,00 & \\
\hline
\end{tabular}

\section{Cambissolo Latossólico}

\begin{tabular}{lrlrlrlrlllll}
$\mathbf{1} / 78,19$ & 13,56 & $\mathbf{a}$ & 9,47 & $\mathbf{a}$ & 2,39 & $\mathbf{a}$ & 7,85 & $\mathbf{a}$ & 4,32 & $\mathbf{a}$ & 35,59 & $\mathbf{a}$ \\
$\mathbf{1} / \mathbf{5 4 , 7 3}$ & 13,43 & $\mathbf{a}$ & 9,43 & $\mathbf{a}$ & 2,29 & $\mathbf{a}$ & 7,91 & $\mathbf{a}$ & 5,54 & $\mathbf{a}$ & 38,60 & $\mathbf{a}$ \\
$\mathbf{1 / 4 3 , 1 1}$ & 9,91 & $\mathbf{a}$ & 13,83 & $\mathbf{a}$ & 2,93 & $\mathbf{a}$ & 11,17 & $\mathbf{a}$ & 4,97 & $\mathbf{a}$ & 42,81 & $\mathbf{a}$ \\
$\mathbf{1 / 3 7 , 6 7}$ & 13,48 & $\mathbf{a}$ & 9,08 & $\mathbf{a}$ & 1,93 & $\mathbf{a}$ & 8,82 & $\mathbf{a}$ & 3,91 & $\mathbf{a}$ & 37,22 & $\mathbf{a}$ \\
$\mathbf{1 / 8 0 , 1 8}$ & 12,23 & $\mathbf{a}$ & 10,58 & $\mathbf{a}$ & 3,30 & $\mathbf{a}$ & 9,20 & $\mathbf{a}$ & 4,94 & $\mathbf{a}$ & 40,25 & $\mathbf{a}$ \\
$\mathbf{1 / 5 0 , 9 4}$ & 14,55 & $\mathbf{a}$ & 10,67 & $\mathbf{a}$ & 2,87 & $\mathbf{a}$ & 8,64 & $\mathbf{a}$ & 5,15 & $\mathbf{a}$ & 41,88 & $\mathbf{a}$ \\
$\mathbf{1 / 5 1 , 8 3}$ & 14,89 & $\mathbf{a}$ & 12,54 & $\mathbf{a}$ & 2,17 & $\mathbf{a}$ & 9,22 & $\mathbf{a}$ & 6,04 & $\mathbf{a}$ & 44,87 & $\mathbf{a}$ \\
$\mathbf{1 / 4 1 , 0 8}$ & 16,04 & $\mathbf{a}$ & 11,64 & $\mathbf{a}$ & 3,05 & $\mathbf{a}$ & 9,28 & $\mathbf{a}$ & 5,91 & $\mathbf{a}$ & 45,92 & $\mathbf{a}$ \\
\hline $\mathbf{C . V} . \mathbf{( \% )}$ & 25,59 & 25,89 & 19,14 & 27,52 & & 18,52 & & 12,56 \\
\hline
\end{tabular}

- nas colunas, médias seguidas pela mesma letra, para cada solo, não diferem significativamente pelo teste de Tukey, ao nível de $5 \%$ de probabilidade. 


\subsubsection{Teores de $K$, Ca e Mg nas Folhas do Feijoeiro}

A literatura tem evidenciado boas correlações entre o teor de $K$ no solo, com o seu teor em várias espécies de plantas. Todavia, neste trabalho essa correlação não foi totalmente comprovada, pois de um modo geral os teores de potássio nas folhas do feijoeiro (na floração e no final do ciclo) não diferem significativamente pelo teste de Tukey, ao nivel de $5 \%$ de probabilidade, em função da elevação do nivel de $K$ trocável, caracterizado pelo aumento na relação $\mathrm{K} /(\mathrm{Ca}+\mathrm{Mg})$ no solo (tabela 11). Possivelmente os teores de potássio trocável existentes nos solos, considerado segundo a RECOMENDAÇÃO DE ADUBAÇÃO E CALAGEM PARA O ESTADO DE SÃO PAULO (1985), muito alto para o LVA e $\mathrm{LA}$, alto para o $\mathrm{CL}$ e médio para $\circ \mathrm{CV}$, sejam as razões de não ocorrerem diferenças de absorção de potássio pelas plantas em função da adubação potássica efetuada. Essa explicação é reforçada ao verificar que extamente no CV e CL onde se encontra os menores teores de potássio trocável (tabela 8), observase na tabela 11, uma tendência de aumento nos teores de potássio na folha do feijoeiro tanto na floração como no final do ciclo, em função do aumento da relação $\mathrm{K} /(\mathrm{Ca}+\mathrm{Mg})$ no solo, podendo ser melhor visualizada através das figuras 9 , 10,11 e 12. Todavia, vale ressaltar que nos gráficos da relação $\mathrm{Ca} / \mathrm{Mg}=4,71$ das figuras 11 e 12, do Cambissolo Latossólico, os modelos não foram significativos, fazendo-se presente apenas para mostrar que abaixando a relação $\mathrm{Ca} / \mathrm{Mg}$ de 6,55 para 4,71 , ocorre uma maior dispersão dos pontos, evidenciando a influência da relação Ca/Mg do solo, sobre o aproveitamento do potássio pelo feijoeiro.

Na tabela 11, observa-se no $L A, C V$ e $C L$ que não houve aumento significativo pelo teste de Tukey a nivel de $5 \%$ na concentração de cálcio nas folhas do feijoeiro (na floração e no final do ciclo) nas quatro primeiras relaçōes $\mathrm{K} /(\mathrm{Ca}+\mathrm{Mg})$, onde a relação $\mathrm{Ca} / \mathrm{Mg}$ é maior, informação essa, que não está de acordo com os resultados obtidos por WADDINGTON et al. (1972) e SOARES (1975 e 1983). Tal fato pode ser explicado em, razão dos niveis muito altos de cálcio trocável originalmente encontrado em ambos os solos. 
Tabela 11. Teores médios de potássio, cálcio e magnésio $(\mathrm{g} / \mathrm{kg})$ nas folhas do feijoeiro, na floração e no final do ciclo da cultura, em função das relações $\mathrm{K} /(\mathrm{Ca}+\mathrm{Mg})$, aplicadas no LVA, LA, CV e CL.

\begin{tabular}{|c|c|c|c|c|c|c|c|}
\hline \multirow[t]{2}{*}{ Relações } & \multicolumn{2}{|c|}{$\mathbf{K}$} & \multicolumn{3}{|c|}{$\mathrm{Ca}$} & \multicolumn{2}{|c|}{$\mathbf{M g}$} \\
\hline & \multicolumn{7}{|c|}{ Ciclo da Cultura } \\
\hline \multirow[t]{2}{*}{$\mathrm{K} / \mathrm{Ca}+\mathbf{M g})$} & floração & final & floração & & final & floração & final \\
\hline & \multicolumn{7}{|c|}{ Latossolo Vermelho Amarelo } \\
\hline $1 / 12,11$ & 38,04 ab & $26,53 \mathbf{a}$ & 17,88 & $\mathbf{a}$ & 76,58 a & $3,36 \mathbf{a}$ & 3,73 a \\
\hline $1 / 11,05$ & $35,31 \quad \mathbf{b}$ & $25,19 \mathbf{a}$ & 16,73 & $\mathbf{a}$ & $76,50 \mathbf{a b}$ & $3,26 \mathbf{a}$ & $3,08 \mathbf{a b}$ \\
\hline $1 / 9,24$ & $37,19 \mathbf{a b}$ & 26,87 a & 16,45 & $\mathbf{a}$ & $73,08 \mathbf{a b}$ & $3,24 \mathbf{a}$ & $3,04 \mathbf{b}$ \\
\hline $1 / 6,86$ & 39,92 a & $26,03 \quad \mathbf{a}$ & 15,77 & $\mathbf{a}$ & $69,75 \mathbf{b}$ & 3,13 a & $2,66 \mathbf{b}$ \\
\hline C.V. $(\%)$ & 7,02 & 7,66 & 12,05 & & 5,68 & 11,23 & 13,57 \\
\hline
\end{tabular}

\section{Latossolo Amarelo}

\begin{tabular}{|c|c|c|c|c|c|c|c|c|c|c|c|}
\hline $1 / 13,22$ & 33,43 & $\mathbf{a}$ & 16,81 & a & 15,88 & $\mathbf{b}$ & 81,50 & $\mathbf{a}$ & 3,50 & $\mathbf{a b}$ & 3,52 \\
\hline $1 / 12,25$ & 37,19 & $\mathbf{a}$ & 17,15 & $\mathbf{a}$ & 20,38 & $\mathbf{a}$ & 76,17 & $\mathbf{a}$ & 4,10 & $\mathbf{a}$ & 3,08 \\
\hline $1 / 10,92$ & 35,48 & $\mathbf{a}$ & 18,82 & $\mathbf{a}$ & 20,13 & $\mathbf{a}$ & 76,33 & $\mathbf{a}$ & 3,18 & $\mathbf{a b}$ & 2,70 \\
\hline $1 / 8,80$ & 35,82 & $\mathbf{a}$ & 20,83 & $\mathbf{a}$ & 18,33 & $\mathbf{a}$ & 71,50 & $\mathbf{a}$ & 3,12 & $\mathbf{b}$ & 2,60 \\
\hline $1 / 17,10$ & 35,82 & $\mathbf{a}$ & 5,08 & b & 20,45 & $\mathbf{a}$ & 76,83 & $\mathbf{a}$ & 3,58 & $\mathbf{a b}$ & 4,57 \\
\hline $1 / 13,59$ & 36,84 & $\mathbf{a}$ & 15,14 & $\mathbf{a}$ & 17,12 & b & 75,66 & $\mathbf{a}$ & 3,79 & $\mathbf{a b}$ & 4,10 \\
\hline $1 / 12,45$ & 36,50 & $\mathbf{a}$ & 17,48 & a & 16,87 & $\mathbf{b}$ & 64,83 & $\mathbf{a}$ & 3,68 & $\mathbf{a b}$ & 2,40 \\
\hline $1 / 10,26$ & 38,21 & $\mathbf{a}$ & 15,81 & $\mathbf{a}$ & 12,38 & c & 64,00 & $\mathbf{a}$ & 3,27 & $\mathbf{a b}$ & 3,40 \\
\hline C.V. $(\%)$ & 8,90 & & 19,93 & & 5,42 & & 13,96 & & 9,44 & & 19,56 \\
\hline
\end{tabular}

\section{Cambissolo Vértico}

\begin{tabular}{|c|c|c|c|c|c|c|c|c|c|c|c|c|}
\hline $1 / 377,51$ & 27,62 & b & 8,43 & cd & 23,78 & $\mathbf{a}$ & 87,00 & $\mathbf{a}$ & 4,57 & bc & 6,35 & b \\
\hline $1 / 242,21$ & 34,45 & $\mathbf{a b}$ & 13,46 & bc & 21,02 & $\mathbf{a b}$ & 85,83 & $\mathbf{a}$ & 3,52 & c & 5,22 & bc \\
\hline $1 / 147,99$ & 37,87 & $\mathbf{a b}$ & 17,48 & $\mathbf{a b}$ & 16,33 & c & 79,83 & $\mathbf{a}$ & 3,12 & c & 3,85 & c \\
\hline $1 / 112,27$ & 33,77 & $\mathbf{a b}$ & 22,17 & $\mathbf{a}$ & 20,83 & $\mathbf{a b}$ & 85,67 & $\mathbf{a}$ & 3,10 & c & 3,95 & c \\
\hline $1 / 471,72$ & 28,99 & b & 6,42 & d & 22,97 & $\mathbf{a b}$ & 87,83 & $\mathbf{a}$ & 6,42 & $\mathbf{a}$ & 11,67 & $\mathbf{a}$ \\
\hline $1 / 235,65$ & 33,77 & $\mathbf{a b}$ & 12,45 & bcd & 19,30 & bc & 91,33 & $\mathbf{a}$ & 5,92 & $\mathbf{a b}$ & 10,83 & $\mathbf{a}$ \\
\hline $1 / 211,78$ & 32,75 & $\mathbf{a b}$ & 12,12 & bed & 22,70 & ab & 93,17 & $\mathbf{a}$ & 5,85 & $\mathbf{a b}$ & 11,00 & $\mathbf{a}$ \\
\hline $1 / 103,23$ & 41,29 & $\mathbf{a}$ & 11,11 & cd & 23,38 & $\mathbf{a b}$ & 89,83 & $\mathbf{a}$ & 4,62 & bc & 11,17 & $\mathbf{a}$ \\
\hline \multirow[t]{2}{*}{ C.V. $(\%)$} & 10,87 & & 16,61 & & 6,92 & & 5,84 & & 13,14 & & 7,45 & \\
\hline & \multicolumn{12}{|c|}{ Cambissolo Latossólico } \\
\hline $1 / 377,51$ & 26,94 & $\mathbf{b}$ & 3,07 & $\mathbf{a}$ & 23,40 & $\mathbf{a}$ & 84,67 & $\mathbf{a b}$ & 4,82 & $\mathbf{a}$ & 11,00 & $\mathbf{a}$ \\
\hline $1 / 242,21$ & 35,82 & $\mathbf{a b}$ & 7,09 & $\mathbf{a}$ & 21,92 & $\mathbf{a}$ & 82,17 & $\mathbf{a b}$ & 4,13 & $\mathbf{a}$ & 6,42 & b \\
\hline $1 / 147,99$ & 33,09 & $\mathbf{a b}$ & 11,44 & $\mathbf{a}$ & 24,33 & $\mathbf{a}$ & 94,00 & $\mathbf{a}$ & 4,75 & $\mathbf{a}$ & 5,23 & b \\
\hline $1 / 112,27$ & 36,84 & $\mathbf{a}$ & 11,45 & $\mathbf{a}$ & 23,45 & $\mathbf{a}$ & 82,00 & $\mathbf{a b}$ & 3,80 & $\mathbf{a}$ & 4,07 & b \\
\hline $1 / 471,72$ & 31,04 & $\mathbf{a b}$ & 8,76 & $\mathbf{a}$ & 23,90 & $\mathbf{a}$ & 83,33 & $\mathbf{a b}$ & 4,65 & $\mathbf{a}$ & 3,90 & b \\
\hline $1 / 235,65$ & 26,94 & $\mathbf{b}$ & 11,11 & $\mathbf{a}$ & 23,15 & $\mathbf{a}$ & 81,50 & $\mathbf{a b}$ & 4,87 & $\mathbf{a}$ & 5,93 & b \\
\hline $1 / 211,78$ & 30,02 & $\mathbf{a b}$ & 8,09 & $\mathbf{a}$ & 21,77 & $\mathbf{a}$ & 74,00 & $\mathbf{b}$ & 4,22 & $\mathbf{a}$ & 10,50 & $\mathbf{a}$ \\
\hline $1 / 103,23$ & 30,02 & $\mathbf{a b}$ & 8,09 & $\mathbf{a}$ & 24,52 & $\mathbf{a}$ & 72,67 & $\mathbf{b}$ & 4,45 & $\mathbf{a}$ & 4,93 & b \\
\hline C.V. $(\%)$ & 10,75 & & 39,54 & & 7,31 & & 7,36 & & 12,39 & & 19,24 & \\
\hline
\end{tabular}

nas colunas, médias seguidas pela mesma letra, para cada solo, não diferem significativamente pelo teste de Tukey, ao nível de $5 \%$ de probabilidade. 

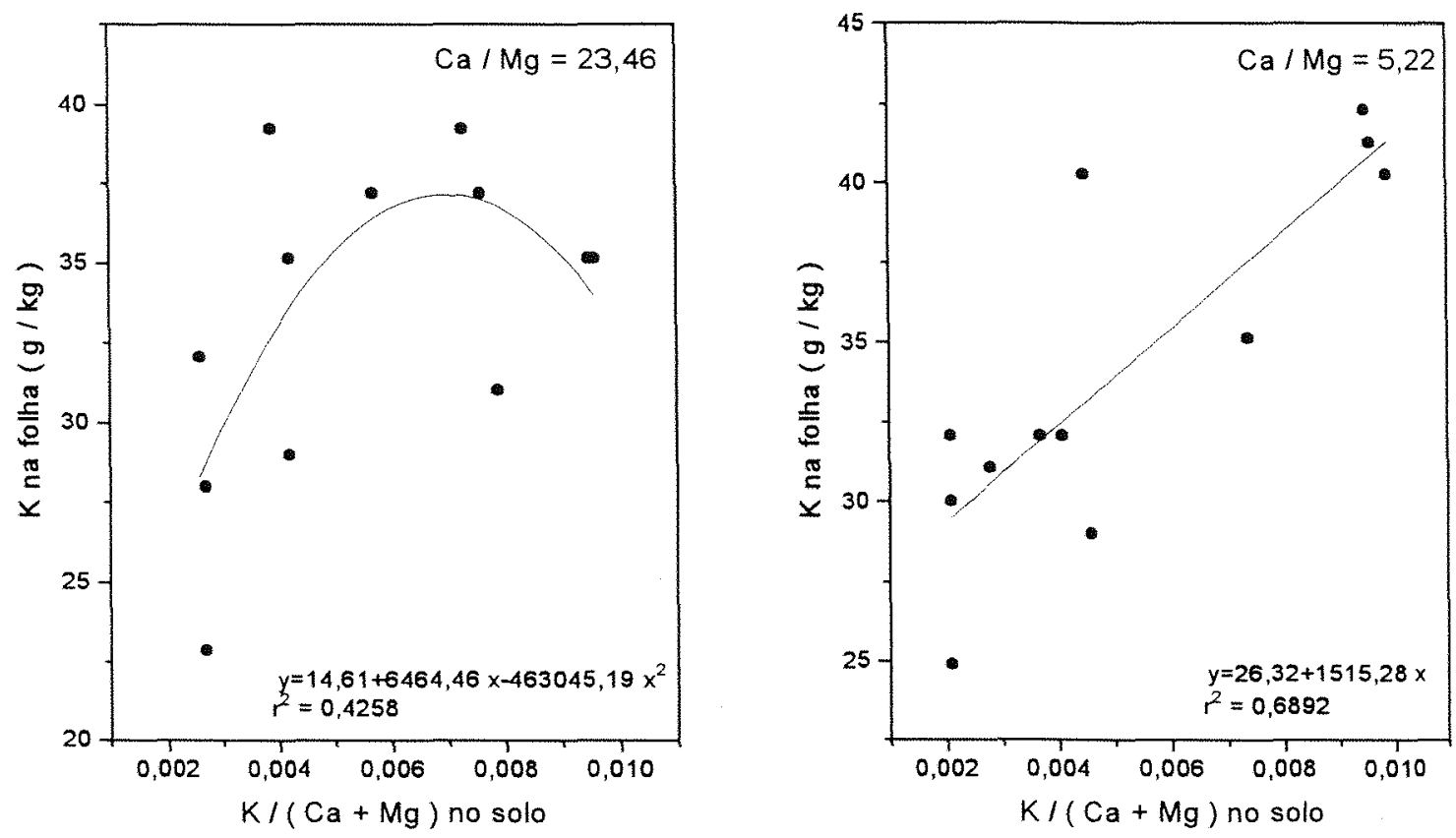

Figura 9. Teores de $\mathrm{K}$ nas folhas do feijoeiro, (na floração), em função das relações $\mathrm{K} /(\mathrm{Ca}+\mathrm{Mg})$ aplicadas no Cambissolo Vértico.
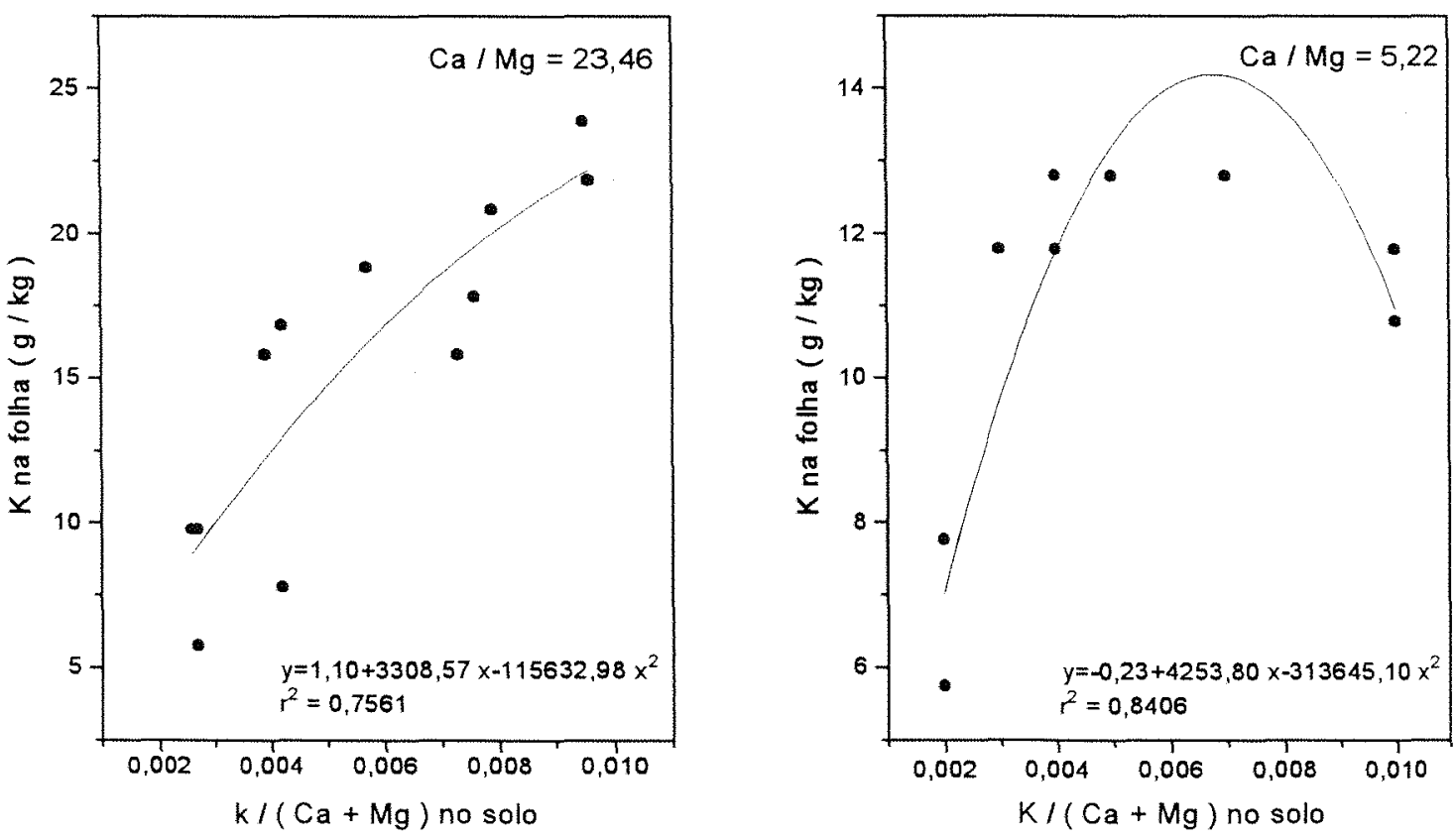

Figura 10. Teores de $\mathrm{K}$ nas folhas do feijoeiro, (final do ciclo), em função das relações $\mathrm{K} /(\mathrm{Ca}+\mathrm{Mg})$ aplicadas no Cambissolo Vértico. 

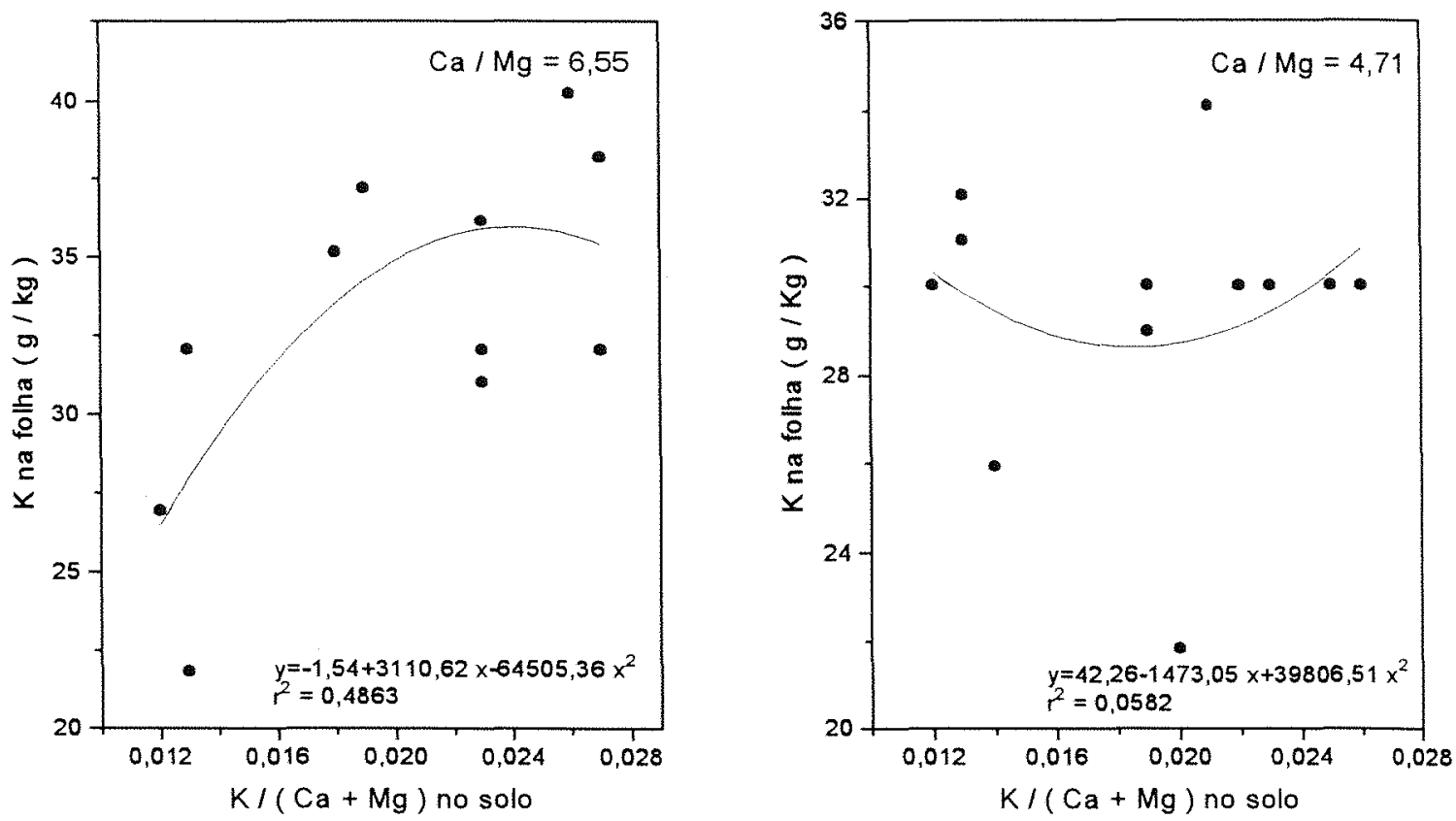

Figura 11. Teores de $\mathrm{K}$ nas folhas do feijoeiro, (na floração), em função das relações $\mathrm{K} /(\mathrm{Ca}+\mathrm{Mg})$ aplicadas no Cambissolo Latossólico.
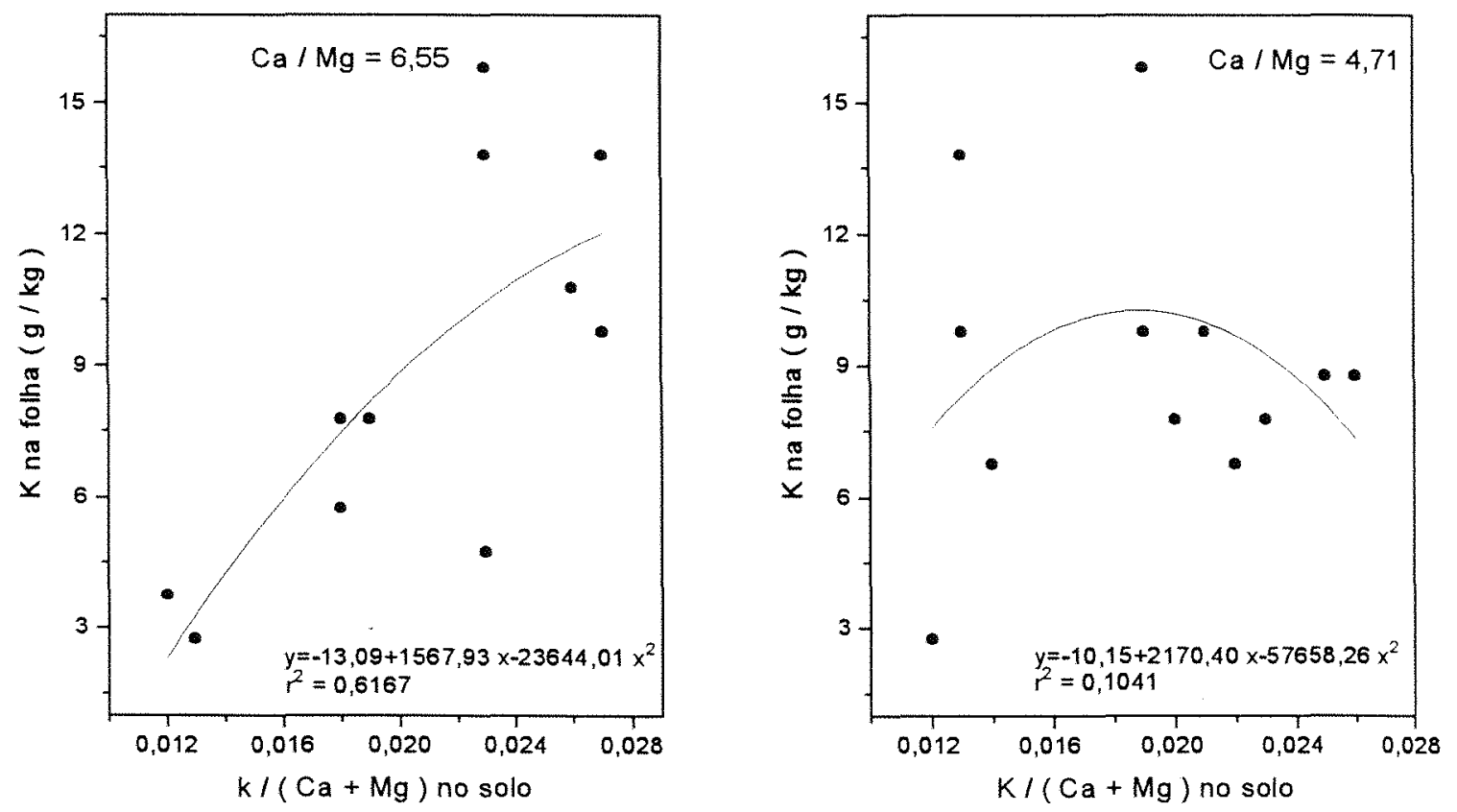

Figura 12. Teores de $\mathrm{K}$ nas folhas do feijoeiro, (final do cíclo ), em função das relações $\mathrm{K} /(\mathrm{Ca}+\mathrm{Mg})$ aplicadas no Cambissolo Latossólico. 
Considerando a tendência dos valores absolutos da absorção de cálcio pelas plantas de feijoeiro (tabela 11). Verifica-se no LVA e LA que a elevação no nível de potássio disponivel caracterizado pelo aumento da relação $\mathrm{K} /(\mathrm{Ca}+\mathrm{Mg})$ no solo, promoveu um decréscimo na absorção do cálcio, apresentando dessa forma um efeito antagônico sobre a absorção daquele cátion (figura 13 , relação $\mathrm{Ca} / \mathrm{Mg}=3,92$ ). Sabendo que ambos os solos possuem níveis muito altos de potássio trocável, com 13,20\% e $11,39 \%$ respectivamente de potássio na soma de bases, essas tendências vem de acordo com BRADWAY \& BUSSLER (1968) e PANDEI (1972) que observaram altas concentrações de potássio reduzirem a absorção de cálcio e magnésio para as culturas de aveia, feijão e girassol. Todavia, observa-se nas relações $1 / 13,22 ; 1 / 12,25 ; 1 / 10,92$ e $1 / 8,80$ e nos teores de cálcio nas folhas do feijoeiro na floração, que nas duas menores relações, onde os niveis de potássio no solo são mais baixos, ocorre uma influência benéfica do mesmo na absorção do cálcio pelas plantas e nas duas maiores relações, passa ocorrer influência depressiva do mesmo sobre a absorção do cálcio, esse sinergismo que ocorre nos níveis mais baixos, seguido de um antagonismo nos níveis mais elevados, pode ser melhor comprovado observando a figura 13 , na relação $\mathrm{Ca} / \mathrm{Mg}=6,12$.

O teor de magnésio nas folhas (floração e final do ciclo) de plantas de feijão, cultivada no solo LVA, LA e CL, não foi influenciado (tabela 11) significativamente pelo aumento da relação $\mathrm{K} /(\mathrm{Ca}+\mathrm{Mg})$ no solo e nem tampouco pela diminuição da relação Ca/Mg. Nestes solos de uma forma geral, a tendência foi uma redução no teor de magnésio com o aumento da relação $\mathrm{K} /(\mathrm{Ca}+\mathrm{Mg})$ no solo, o que pode ser visto na figura 14 , como exemplo do que ocorre nos três solos, observando ainda, que com a diminuição da relação $\mathrm{Ca} / \mathrm{Mg}$, ocorreu uma maior dispersão dos pontos, tornando o modelo não significativo e provocando um maior desequilíbrio dos cátions no solo. Esses resultados vem de encontro com OMAR \& KOBBIA (1966) que observaram redução na absorção de magnésio em função do aumento nas concentrações de potássio.

No CV tabela 11, o teor de magnésio nas folhas do feijoeiro,na floração e no final do ciclo, não diferem significativamente pelo teste de Tukey ao nível de $5 \%$ de probabilidade, em função da elevação do nível de potássio, caracterizado pelo aumento da relação $\mathrm{K} /(\mathrm{Ca}+\mathrm{Mg})$ no solo, todavia, difere quanto a relação $\mathrm{Ca} / \mathrm{Mg}$. Percebe-se que ocorreu uma maior absorção de magnésio nas 
relações $1 / 471,72 ; 1 / 235,65 ; 1 / 211,78$ e $1 / 103,23$ quando diminuiu-se a relação $\mathrm{Ca} / \mathrm{Mg}$ de 23,46 para 5,22 . Pela tabela 10 visualiza-se que essa maior absorção de magnésio pela planta de feijão nessas relações, não interferiu na produção de grãos nem de matéria seca de folhas, raizes, caule + ramos e vagens. Nas figuras 15 e 16 nota-se, que o maior teor de magnésio nas folhas do feijoeiro na relação $\mathrm{Ca} / \mathrm{Mg}=5,23$, provocou uma maior dispersão dos dados, tornando o modelo não significativo.

Levando em conta a variação do $\mathrm{K}, \mathrm{Ca}$ e $\mathrm{Mg}$ nas folhas do feijoeiro na floração e no final do ciclo, observou-se nessa ensaio tabela 11 , que os teores de $\mathrm{K}$ são mais elevados na floração, sugerindo que a translocação principalmente para formação das vagens seja a razão do ocorrido. Já os teores de Ca foram bem maiors nas folhas no final do ciclo que na floração, este aumento deve ter ocorrido em razão do desenvolvimento da planta, aliada a falta de redistribuição interna em função da sua mobilidade. Os teores de $\mathrm{Mg}$ na floração e no final do ciclo foram mais ou menos constantes, com pequena excessão. As variações encontradas nesse ensaio estão de acordo com os obtidos por HAAG et al. (1967). É importante chamar atenção que o teor de cálcio encontrado nesse trabalho, nas folhas do feijoeiro no final do ciclo, foi em média quatro vezes maior que o considerado adequado por MALAVOLTA et al. (1989). Todavia chama atenção os autores, que os valores indicados são muito gerais, e que condições de solo, clima e variedade poderão influenciar os mesmos. Nesse trabalho em particular, com certeza o solo influenciou bastante por se tratar de um solo calcário. 

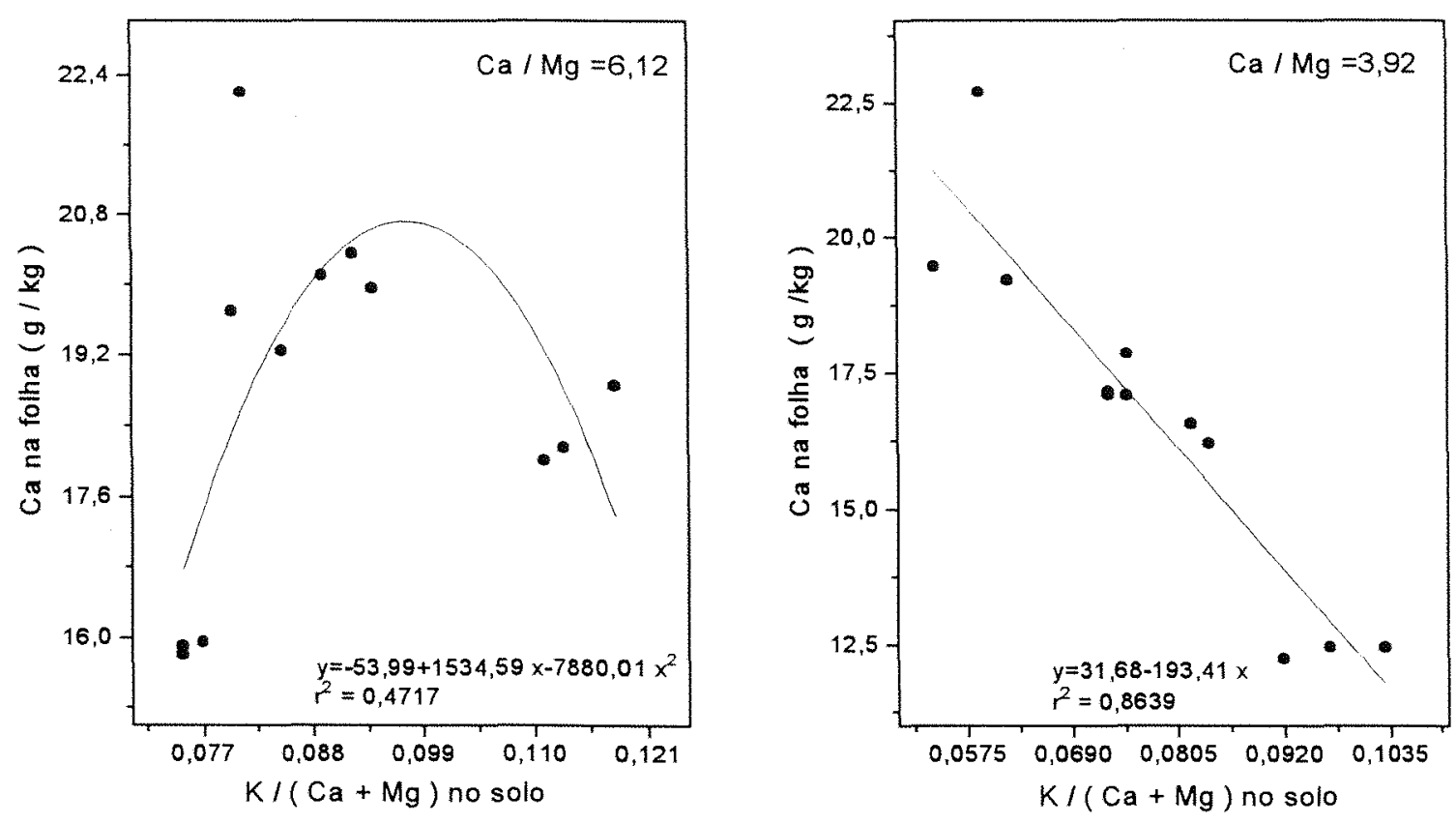

Figura 13. Teores de Ca nas folhas do feijoeiro, (na floração), em função das relações $\mathrm{K} /(\mathrm{Ca}+\mathrm{Mg})$ aplicadas no Latossolo Amarelo.
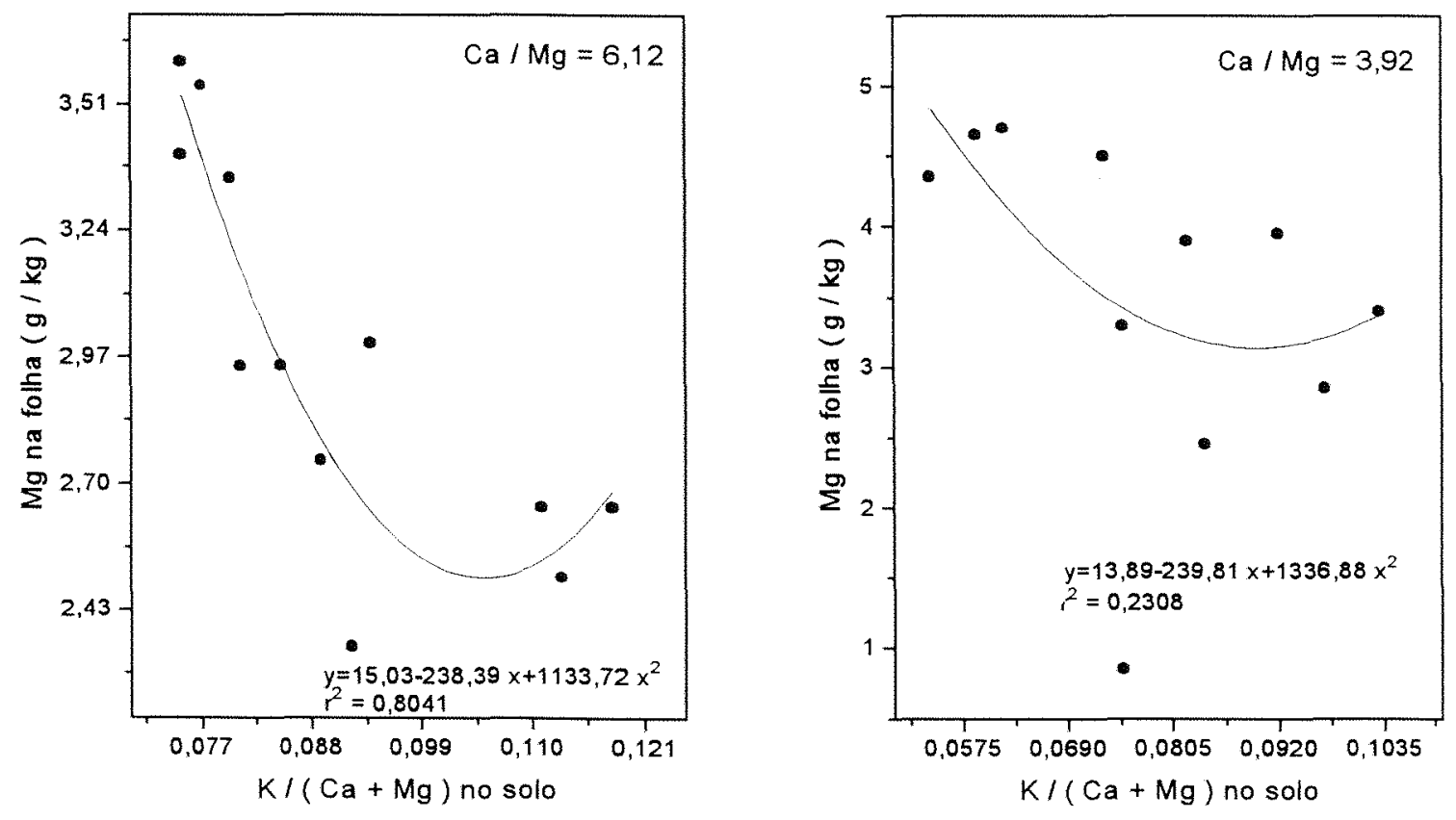

Figura 14. Teores de $\mathrm{Mg}$ nas folhas do feijoeiro, (final do cíclo ), em função das relações $\mathrm{K} /(\mathrm{Ca}+\mathrm{Mg})$ aplicadas no Latossolo Amarelo. 

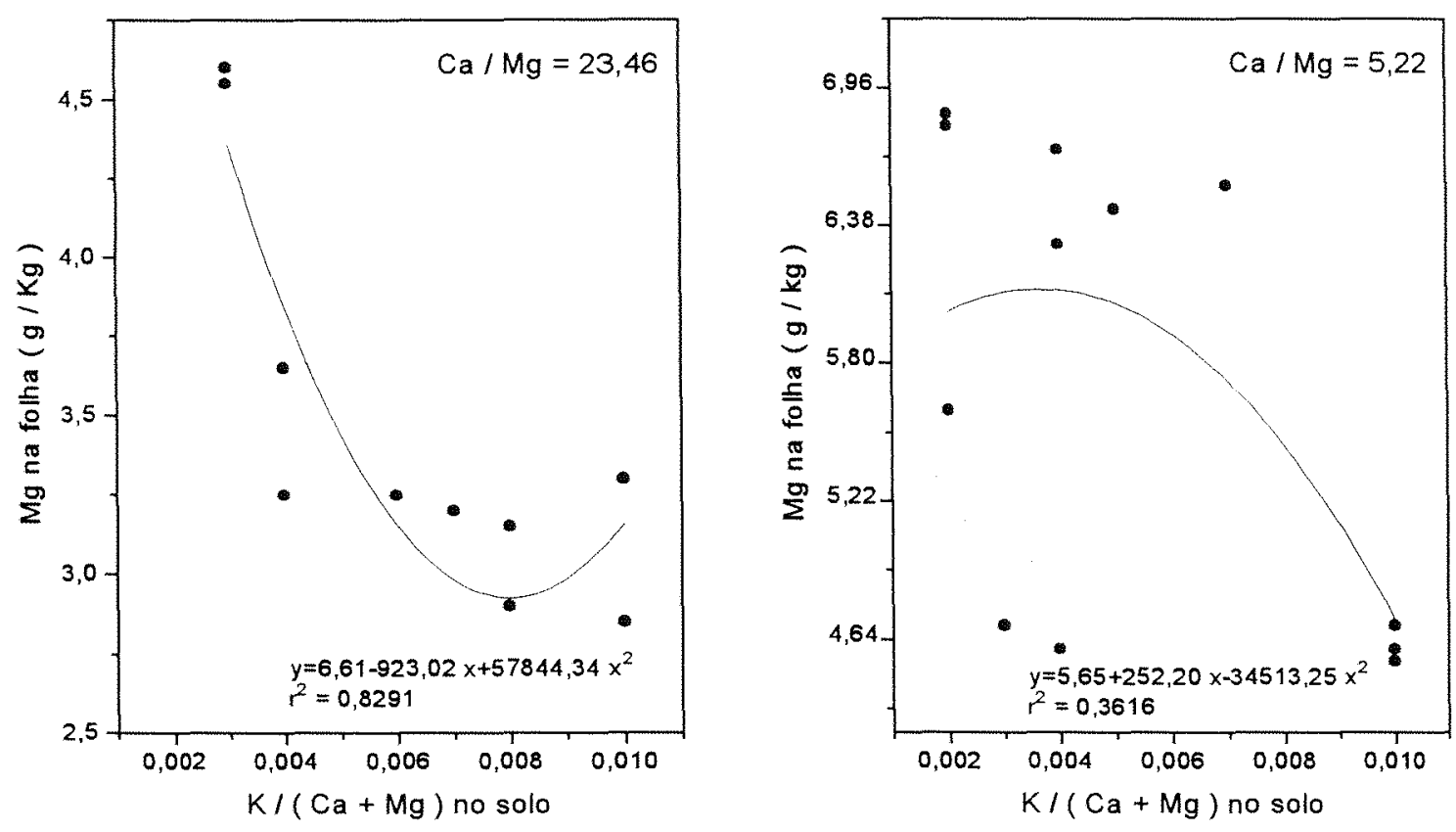

Figura 15. Teores de Mg nas folhas do feijoeiro, ( na floração), em função das relações $\mathrm{K} /(\mathrm{Ca}+\mathrm{Mg})$ aplicadas no Cambissolo Vértico.
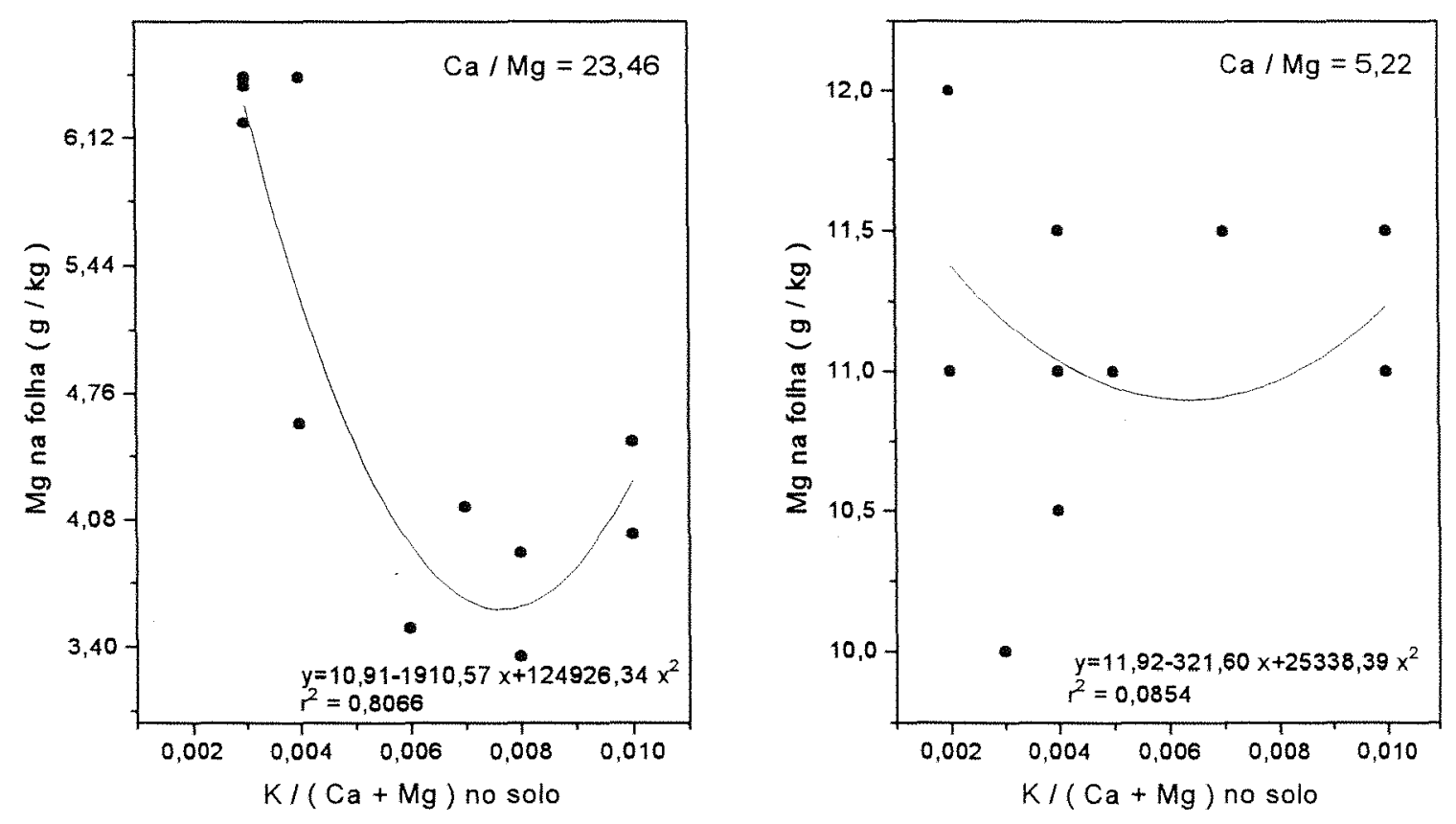

Figura 16. Teores de $\mathrm{Mg}$ nas folhas do feijoeiro, ( final do ciclo ), em função das relações $\mathrm{K} /(\mathrm{Ca}+\mathrm{Mg})$ aplicadas no Cambissolo Vértico. 


\subsubsection{Teores e Conteúdos de $K, \mathrm{Ca}$ e Mg nos Grãos do Feijoeiro em Função das Relações K(Ca+Mg) Aplicadas nos Solos}

Observando a tabela 12, onde encontram-se os valores médios de potássio, cálcio e magnésio nos grãos do feijoeiro, tanto em teor como em conteúdo, nota-se que essas médias não diferem significativamente pelo teste de Tukey ao nivel de $5 \%$ de probabilidade, em função do incremento da relação $\mathrm{K} /(\mathrm{Ca}+\mathrm{Mg})$ nos solos LVA, LA, CV e CL. Todavia, nas figuras 17 e 18 do LA, observa-se uma tendência de aumento de teor e quantidade de cálcio nos grãos do feijoeiro com o incremento da relação $\mathrm{K} /(\mathrm{Ca}+\mathrm{Mg})$ no solo. Vale ressaltar, que esse aumento nos teores de cálcio nos grãos do feijoeiro em função dos tratamentos aplicados, em nada influi na produção de grãos. Visualiza-se também nas figuras 17 e 18, que com a diminuição da relação $\mathrm{Ca} / \mathrm{Mg}$, o modelo linear não foi significativo, apresentando uma dispersão muito grande dos pontos.

É conveniente chamar atenção na tabela 12, que os teores de $\mathrm{K}, \mathrm{Ca}$ e Mg nos grãos do feijoeiro, assemelha-se aos resultados obtidos por EL-HUSNY (1992); HAAG et al. (1967) e COBRA NETO et al. (1971), com pequenas variações em função das diferenças entre tratamentos, cultivares e metodologias peculiares de cada ensaio. Considerando, que somente os grãos abandonaram a propriedade agrícola, tona-se interessante observar na tabela 12 , através dos seus valores médios de conteúdo, que o potássio foi o nutriente mais exportado seguido do cálcio e magnésio, o que está de acordo com os três autores citados. Apesar da literatura sempre afirmar ser o feijoeiro muito exigente em cálcio, somente uma pequena fração de cálcio é exportado através da colheita de grãos. 
Tabela 12. Valores médios de potássio, cálcio e magnésio em teor $(\mathrm{g} / \mathrm{kg})$ e conteúdo (mg/vaso) nos grãos do feijoeiro, em função das relações $\mathrm{K} /(\mathrm{Ca}+\mathrm{Mg})$ aplicadas no LVA, LA, CV e CL.

\begin{tabular}{|c|c|c|c|c|c|c|c|c|c|c|}
\hline \multirow{3}{*}{$\begin{array}{c}\text { Relacóes } \\
\mathbf{K} /(\mathbf{C a}+\mathbf{M g})\end{array}$} & \multicolumn{3}{|c|}{$\mathbf{K}$} & \multicolumn{3}{|c|}{$\mathrm{Ca}$} & \multicolumn{4}{|c|}{$\mathrm{Mg}$} \\
\hline & \multicolumn{10}{|c|}{ Producão de Grãos } \\
\hline & \multicolumn{2}{|l|}{ teor } & conteúdo & \multicolumn{2}{|c|}{ teor } & conteúdo & \multicolumn{2}{|c|}{ teor } & \multicolumn{2}{|c|}{ conteúdo } \\
\hline & \multicolumn{10}{|c|}{$\underline{\text { Latossolo Vermelho Amarelo }}$} \\
\hline $1 / 12,11$ & 13,61 & $\mathbf{a}$ & $195,57 \mathbf{a}$ & 1,85 & $\mathbf{a}$ & $26,50 \quad a$ & 1,92 & $\mathbf{a}$ & 27,55 & $\mathbf{a}$ \\
\hline $1 / 11,05$ & 13,78 & $\mathbf{a}$ & $221,06 \mathbf{a}$ & 1,17 & $\mathbf{a}$ & 17,58 a & 1,78 & $\mathbf{a}$ & 28,33 & $\mathbf{a}$ \\
\hline $1 / 9,24$ & 12,61 & $\mathbf{a}$ & 201,52 a & 1,28 & $\mathbf{a}$ & $19,30 \quad \mathbf{a}$ & 1,83 & $\mathbf{a}$ & 28,71 & $\mathbf{a}$ \\
\hline $1 / 6,86$ & 12,78 & $\mathbf{a}$ & $217,80 \quad \mathbf{a}$ & 1,18 & $\mathbf{a}$ & $20,24 \quad \mathbf{a}$ & 1,71 & $\mathbf{a}$ & 29,41 & $\mathbf{a}$ \\
\hline C.V. $(\%)$ & 8,24 & & 19,12 & 35,79 & & 34,39 & 7,85 & & 18,30 & \\
\hline
\end{tabular}

\begin{tabular}{|c|c|c|c|c|c|c|c|c|c|c|c|c|}
\hline $1 / 13,22$ & 10,45 & $\mathbf{a}$ & 168,27 & $\mathbf{a}$ & 1,12 & c & 18,14 & $\mathbf{a}$ & 1,67 & b & 26,91 & $\mathbf{a}$ \\
\hline $1 / 12,25$ & 13,11 & $\mathbf{a}$ & 196,21 & $\mathbf{a}$ & 1,73 & $\mathbf{b}$ & 26,39 & $\mathbf{a}$ & 1,90 & $\mathbf{a}$ & 28,65 & $\mathbf{a}$ \\
\hline $1 / 10,92$ & 11,78 & $\mathbf{a}$ & 174,12 & $\mathbf{a}$ & 2,10 & $\mathbf{a b}$ & 31,01 & $\mathbf{a}$ & 1,95 & $\mathbf{a}$ & 28,91 & $\mathbf{a}$ \\
\hline $1 / 8,80$ & 12,11 & $\mathbf{a}$ & 198,74 & $\mathbf{a}$ & 2,25 & $\mathbf{a}$ & 37,11 & $\mathbf{a}$ & 1,93 & $\mathbf{a}$ & 31,95 & $\mathbf{a}$ \\
\hline $1 / 17,10$ & 12,11 & $\mathbf{a}$ & 162,87 & $\mathbf{a}$ & 2,20 & $\mathbf{a}$ & 30,78 & $\mathbf{a}$ & 1,93 & $\mathbf{a}$ & 27,29 & $\mathbf{a}$ \\
\hline $1 / 13,59$ & 12,78 & $\mathbf{a}$ & 206,09 & $\mathbf{a}$ & 2,35 & $\mathbf{a}$ & 37,71 & $\mathbf{a}$ & 1,98 & $\mathbf{a}$ & 31,86 & $\mathbf{a}$ \\
\hline $1 / 12,45$ & 13,45 & $\mathbf{a}$ & 186,78 & $\mathbf{a}$ & 2,27 & $\mathbf{a}$ & 30,44 & $\mathbf{a}$ & 1,92 & $\mathbf{a}$ & 25,83 & $\mathbf{a}$ \\
\hline $1 / 10,26$ & 12,78 & $\mathbf{a}$ & 195,06 & $\mathbf{a}$ & 2,27 & $\mathbf{a}$ & 34,88 & $\mathbf{a}$ & 2,00 & $\mathbf{a}$ & 30,64 & $\mathbf{a}$ \\
\hline C.V. $(\%)$ & 10,21 & & 25,33 & & 7,17 & & 25,98 & & 4,10 & & 24,66 & \\
\hline
\end{tabular}

\begin{tabular}{|c|c|c|c|c|c|c|c|c|c|c|c|c|}
\hline $1 / 377,51$ & 12,78 & $\mathbf{a}$ & 209,03 & $\mathbf{a}$ & 2,17 & $\mathbf{a}$ & 35,52 & $\mathbf{a}$ & 1,92 & $\mathbf{a}$ & 31,41 & $\mathbf{a}$ \\
\hline $1 / 242,21$ & 12,11 & $\mathbf{a}$ & 153,37 & $\mathbf{a}$ & 2,12 & $\mathbf{a}$ & 26,63 & $\mathbf{a}$ & 1,80 & $\mathbf{a}$ & 22,60 & $\mathbf{a}$ \\
\hline $1 / 147,99$ & 15,45 & $\mathbf{a}$ & 161,63 & $\mathbf{a}$ & 2,12 & $\mathbf{a}$ & 21,73 & $\mathbf{a}$ & 1,88 & $\mathbf{a}$ & 19,37 & $\mathbf{a}$ \\
\hline $1 / 112,27$ & 13,45 & $\mathbf{a}$ & 163,62 & $\mathbf{a}$ & 2,10 & $\mathbf{a}$ & 27,19 & a & 1,88 & $\mathbf{a}$ & 24,20 & $\mathbf{a}$ \\
\hline $1 / 471,72$ & 14,11 & $\mathbf{a}$ & 174,46 & $\mathbf{a}$ & 2,07 & $\mathbf{a}$ & 25,57 & $\mathbf{a}$ & 1,78 & $\mathbf{a}$ & 22,07 & $\mathbf{a}$ \\
\hline $1 / 235,65$ & 14,11 & $\mathbf{a}$ & 140,17 & $\mathbf{a}$ & 2,10 & $\mathbf{a}$ & 20,99 & $\mathbf{a}$ & 1,83 & $\mathbf{a}$ & 18,37 & $\mathbf{a}$ \\
\hline $1 / 211,78$ & 15,11 & $\mathbf{a}$ & 179,55 & $\mathbf{a}$ & 2,02 & $\mathbf{a}$ & 23,86 & $\mathbf{a}$ & 1,78 & $\mathbf{a}$ & 21,15 & $\mathbf{a}$ \\
\hline $1 / 103,23$ & 14,11 & $\mathbf{a}$ & 175,85 & $\mathbf{a}$ & 2,22 & $\mathbf{a}$ & 27,26 & $\mathbf{a}$ & 1,78 & $\mathbf{a}$ & 22,14 & $\mathbf{a}$ \\
\hline \multirow[t]{2}{*}{ C.V. $(\%)$} & 9,96 & & 21,60 & & 7,14 & & 23,56 & & 4,34 & & 23,27 & \\
\hline & \multicolumn{12}{|c|}{ Cambissolo Latossólico } \\
\hline $1 / 377,51$ & 12,45 & $\mathbf{a}$ & 168,76 & $\mathbf{a}$ & 2,18 & $\mathbf{b}$ & 29,60 & $\mathbf{a b}$ & 1,75 & $\mathbf{a}$ & 23,73 & $\mathbf{a}$ \\
\hline $1 / 242,21$ & 12,78 & $\mathbf{a}$ & 171,67 & $\mathbf{a}$ & 2,18 & b & 29,20 & $\mathbf{a b}$ & 1,75 & $\mathbf{a}$ & 23,26 & $\mathbf{a}$ \\
\hline $1 / 147,99$ & 15,45 & $\mathbf{a}$ & 146,03 & $\mathbf{a}$ & 2,65 & $\mathbf{a b}$ & 24,29 & b & 1,88 & $\mathbf{a}$ & 18,57 & $\mathbf{a}$ \\
\hline $1 / 112,27$ & 11,78 & $\mathbf{a}$ & 159,34 & $\mathbf{a}$ & 2,12 & b & 28,52 & $\mathbf{a b}$ & 1,65 & $\mathbf{a}$ & 22,27 & $\mathbf{a}$ \\
\hline $1 / 471,72$ & 11,78 & $\mathbf{a}$ & 146,43 & $\mathbf{a}$ & 2,22 & b & 27,08 & $\mathbf{b}$ & 1,63 & $\mathbf{a}$ & 20,24 & $\mathbf{a}$ \\
\hline $1 / 235,65$ & 13,11 & $\mathbf{a}$ & 192,44 & $\mathbf{a}$ & 2,23 & b & 32,52 & $\mathbf{a b}$ & 1,63 & $\mathbf{a}$ & 23,84 & $\mathbf{a}$ \\
\hline $1 / 211,78$ & 13,11 & $\mathbf{a}$ & 193,81 & $\mathbf{a}$ & 2,27 & b & 33,72 & $\mathbf{a b}$ & 1,72 & $\mathbf{a}$ & 25,61 & $\mathbf{a}$ \\
\hline $1 / 103,23$ & 14,11 & $\mathbf{a}$ & 220,72 & $\mathbf{a}$ & 3,43 & $\mathbf{a}$ & 54,71 & $\mathbf{a}$ & 1,77 & $\mathbf{a}$ & 28,55 & $\mathbf{a}$ \\
\hline C.V. $(\%)$ & 13,16 & & 27,01 & & 15,71 & & 29,99 & & 5,86 & & 27,74 & \\
\hline
\end{tabular}

nas colunas, médias seguidas pela mesma letra, para cada solo, não diferem significativamente pelo teste de Tukey, ao nível de $5 \%$ de probabilidade. 

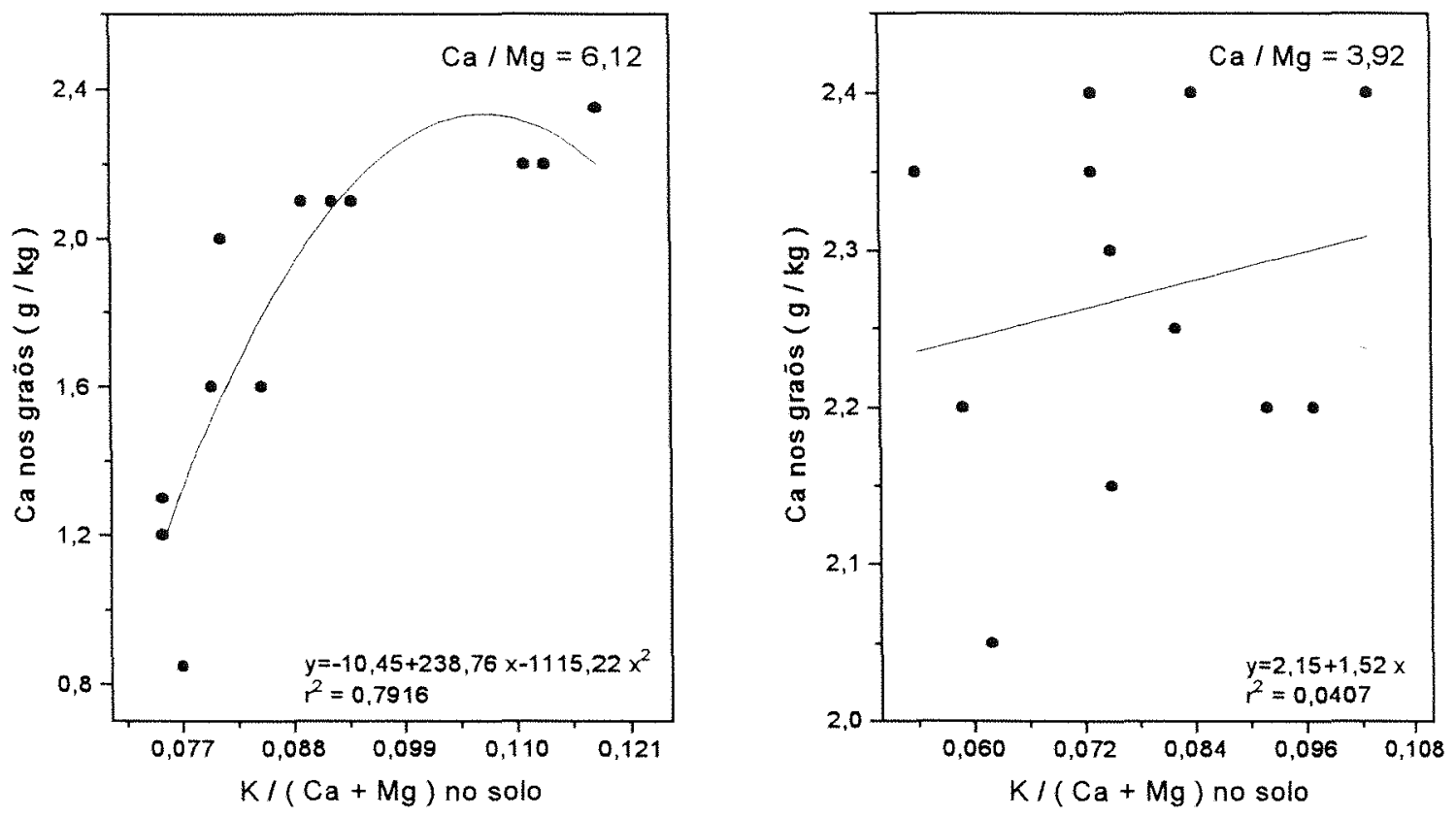

Figura 17. Teores de Ca nos graõs do feijoeiro, em função das relações $\mathrm{K} /(\mathrm{Ca}+\mathrm{Mg})$ aplicadas no Latossolo Amarelo.
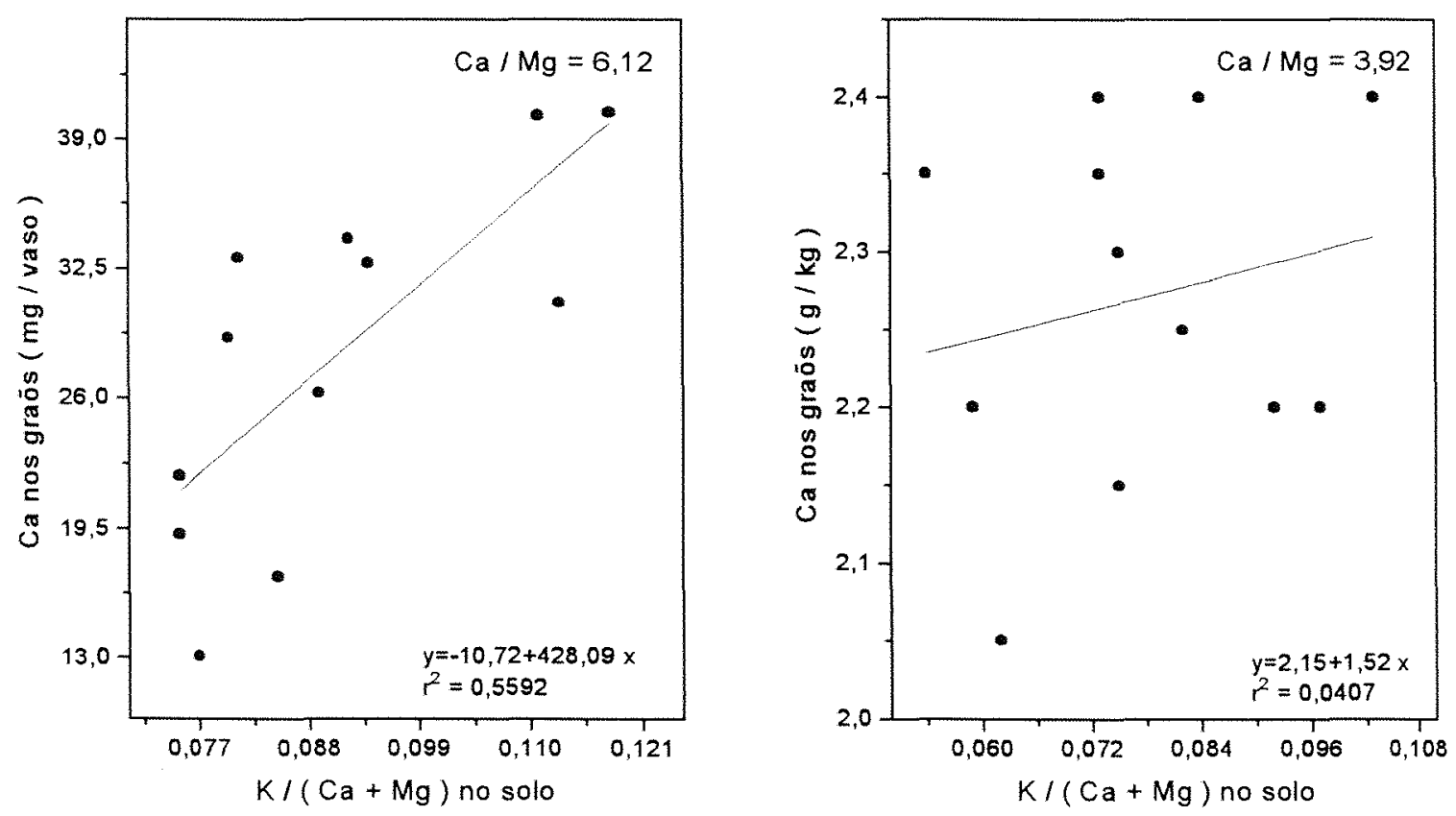

Figura 18. Quantidade de $\mathrm{Ca}$ nos graõs do feijoeiro, em função das relações $\mathrm{K} /(\mathrm{Ca}+\mathrm{Mg})$ aplicadas no Latossolo Amarelo. 


\subsubsection{Potencial de $K$ em Função das relações $K /(C a+M g)$ Aplicadas nos Solos}

O potencial de potássio estima a relação nutricional na solução do solo entre o cátion monovalente $\mathrm{K}$ e os divalentes $\mathrm{Ca}+\mathrm{Mg}$ (BULL, 1986), a partir do qual pode-se chegar a energia livre do $K$ no solo $(\Delta \bar{G})$, que determina a quantidade de trabalho que uma planta tem que realizar para deslocar em equivalente grama de nutriente do solo.

Ambos os parâmetros podem ser visualizados na tabela 13, onde se vê:

1. no LVA. O potencial de potássio-cálcio-magnésio antes do cultivo variou de 1,13 a 1,29 e após o cultivo 1,38 a 1,75 ; a energia livre de $K$ no solo $(\Delta \bar{G})$ antes do cultivo -1756 a -1546 cal/eq e após cultivo -2386 a -1881 cal/eq.

2. No LA. Nas quatro primeiras relações $\mathrm{K} /(\mathrm{Ca}+\mathrm{Mg})$, onde a relação $\mathrm{Ca} / \mathrm{Mg}$ foi 6,12 , o potencial de $K$ variou antes do cultivo de 1,31 a 1,46 e após o cultivo de 1,75 a 1,97; $\Delta \overline{\mathrm{G}}$ antes do cultivo de -1995 a -1788 cal/eq e após de -2686 a $2384 \mathrm{cal} / \mathrm{eq}$. Nas quatro últimas relações $\mathrm{K} /(\mathrm{Ca}+\mathrm{Mg})$, na relação $\mathrm{Ca} / \mathrm{Mg}$ igual 3,92 , o potencial de $K$ variou antes do cultivo de 1,42 a 1,56 e após 1,74 a 2,01; $\circ \Delta \overline{\mathrm{G}}$ antes do cultivo de -2125 a -1934 cal/eq após -2742 a -2379 cal/eq.

3. No $\mathrm{CV}$. nas quatro primeiras relações $\mathrm{K} /(\mathrm{Ca}+\mathrm{Mg})$, que possui a relação $\mathrm{Ca} / \mathrm{Mg}=$ 23,46 , o potencial de $K$ variou antes do cultivo de 1,95 a 2,61 e após 2,62 a 3,13; o $\Delta \bar{G}$ antes do cultivo de -3563 a -2655 cal/eq e após -4571 a -3580 cal/eq. Nas quatro últimas relações $\mathrm{K} /(\mathrm{Ca}+\mathrm{Mg})$, com a relação $\mathrm{Ca} / \mathrm{Mg}=5,22$, o potencial de $K$ variou antes do cultivo de 2,05 a 2,73 e após 2,12 a 2,92; o $\Delta \mathrm{G}$ antes do cultivo de -3727 a -2792 cal/eq e após -3986 a -2895 cal/eq.

4. No $C L$. Nas quatro primeiras relações $\mathrm{K} /(\mathrm{Ca}+\mathrm{Mg})$, com a relação $\mathrm{Ca} / \mathrm{Mg}=6,55$, o potencial de $\mathrm{K}$ variou antes do cultivo de 1,99 a 2,36 e após 2,10 a 2,75; o $\Delta \overline{\mathrm{G}}$ antes do cultivo de -3220 a -2717 cal/eq. E após de -3757 a -2862 cal/eq. Nas 
quatro útimas relações $\mathrm{K} /(\mathrm{Ca}+\mathrm{Mg})$, com Ca/Mg $=4,71$; o potencial de $\mathrm{K}$ variou antes do cultivo de 2,03 a 2,39 e após 2,47 a 2,72; o $\Delta \bar{G}$ antes do cultivo -3261 e $-2775 \mathrm{cal} / \mathrm{eq}$ e após o cultivo -3713 a $-3374 \mathrm{cal} / \mathrm{eq}$.

Pela tabela 13 , tanto para o potencial de $\mathrm{K}$ como para o $\Delta \overline{\mathrm{G}}$, observa-se no LVA antes e após o cultivo e no LA, CV e CL antes do cultivo, que as médias diferem significativamente pelo teste de Tukey, ao nivel de $5 \%$ de probabilidade. Todavia, não diferem para $\mathrm{LA}, \mathrm{CV}$ e $\mathrm{CL}$ após o cultivo. No $\mathrm{LA}, \mathrm{CV}$ e $\mathrm{CL}$ antes do cultivo onde as médias diferem significativamente, percebe-se também a influência da relação $\mathrm{Ca} / \mathrm{Mg}$ no solo sobre o potencial de $\mathrm{K}$ e $\Delta \overline{\mathrm{G}}$, resultado esse que concorda com SOARES (1975). 
Tabela 13. Potencial de potássio (pK-0,5p(Ca+Mg)), e energia livre de troca $\Delta \bar{G}(1364 \log$ $(\mathrm{aK} / \sqrt{a(C a+M g)})$ em calorias/equivalente antes e após o cultivo dos solos, em função das relações $K /(C a+M g)$, aplicadas no LVA, LA, CV e CL.

\begin{tabular}{|c|c|c|c|c|c|c|c|}
\hline \multirow{2}{*}{$\begin{array}{c}\text { Relações } \\
\mathrm{K} /(\mathrm{Ca}+\mathrm{Mg})\end{array}$} & \multicolumn{3}{|c|}{ Potencial de K } & \multicolumn{4}{|c|}{$\Delta G$} \\
\hline & Antes & & Após & Antes & & Após & \\
\hline \multicolumn{8}{|c|}{ Latossolo Vermelho Amarelo } \\
\hline $1 / 12,11$ & 1,29 & $\mathbf{a}$ & $1,75 \mathbf{a}$ & -1756 & d & -2386 & c \\
\hline $1 / 11,05$ & 1,27 & $\mathbf{b}$ & $1,59 \mathbf{b}$ & -1733 & c & -2169 & $\mathbf{b}$ \\
\hline $1 / 9,24$ & 1,21 & c & $1,53 \mathrm{bc}$ & -1650 & b & -2085 & $\mathbf{a b}$ \\
\hline $1 / 6,86$ & 1,13 & d & $1,38 \mathrm{c}$ & -1546 & $\mathbf{a}$ & -1881 & $\mathbf{a}$ \\
\hline $\mathrm{CV}(\%)$ & 0,54 & & 5,93 & $-0,54$ & & $-5,94$ & \\
\hline \multicolumn{8}{|c|}{ Latossolo Amarelo } \\
\hline $1 / 13,22$ & 1,46 & c & $1,97 \mathbf{a}$ & -1995 & d & -2686 & $\mathbf{a}$ \\
\hline $1 / 12,25$ & 1,43 & d & $1,78 \quad a$ & -1956 & c & -2430 & $\mathbf{a}$ \\
\hline $1 / 10,92$ & 1,37 & $\mathbf{e}$ & $1,96 \mathbf{a}$ & -1871 & b & -2669 & $\mathbf{a}$ \\
\hline $1 / 8,80$ & 1,31 & f & 1,75 a & -1788 & $\mathbf{a}$ & -2384 & $\mathbf{a}$ \\
\hline $1 / 17,10$ & 1,56 & $\mathbf{a}$ & $2,01 \mathrm{a}$ & -2125 & f & -2742 & $\mathbf{a}$ \\
\hline $1 / 13,59$ & 1,53 & b & $1,95 \mathbf{a}$ & -2087 & $\mathbf{e}$ & -2663 & $\mathbf{a}$ \\
\hline $1 / 12,45$ & 1,47 & c & $1,80 \mathrm{a}$ & -2010 & d & -2455 & a \\
\hline $1 / 10,26$ & 1,42 & d & 1,74 a & -1934 & c & -2379 & $\mathbf{a}$ \\
\hline CV $(\%)$ & 0,63 & & 8,06 & $-0,63$ & & $-8,06$ & \\
\hline \multicolumn{8}{|c|}{ Cambissolo Vértico } \\
\hline $1 / 377,51$ & 2,61 & $\mathbf{a}$ & 3,13 a & -3563 & d & -4571 & $\mathbf{b}$ \\
\hline $1 / 242,21$ & 2,38 & b & 2,84 a & -3245 & c & -3871 & b \\
\hline $1 / 147,99$ & 2,12 & cd & 2,83 a & -2893 & $\mathbf{a b}$ & -3864 & b \\
\hline $1 / 112,27$ & 1,95 & d & $2,62 \mathbf{a b}$ & -2655 & $\mathbf{a}$ & -3580 & $\mathbf{a b}$ \\
\hline $1 / 471,72$ & 2,73 & $\mathbf{a}$ & 2,92 a & -3727 & d & -3986 & $\mathbf{b}$ \\
\hline $1 / 235,65$ & 2,35 & b & $2,54 \mathbf{a b}$ & -3210 & c & -3458 & $\mathbf{a b}$ \\
\hline $1 / 211,78$ & 2,32 & bc & $2,77 \mathbf{a b}$ & -3168 & bc & -3779 & $\mathbf{a b}$ \\
\hline $1 / 103,23$ & 2,05 & d & $2,12 \quad \mathbf{b}$ & -2792 & $\mathbf{a}$ & -2895 & $\mathbf{a}$ \\
\hline CV $(\%)$ & 3,34 & & 9,04 & $-3,34$ & & $-9,04$ & \\
\hline \multicolumn{8}{|c|}{ Cambissolo Latossólico } \\
\hline $1 / 377,51$ & 2,36 & $\mathbf{a}$ & $2,10 \mathbf{b}$ & -3220 & d & -2862 & $\mathbf{a}$ \\
\hline $1 / 242,21$ & 2,19 & $\mathbf{b}$ & 2,75 a & -2988 & c & -3744 & $\mathbf{b}$ \\
\hline $1 / 147,99$ & 2,08 & bcd & 2,75 a & -2838 & $\mathbf{a b c}$ & -3757 & $\mathbf{b}$ \\
\hline $1 / 112,27$ & 1,99 & d & $2,48 \mathbf{a b}$ & -2717 & $\mathbf{a}$ & -3379 & $\mathbf{a b}$ \\
\hline $1 / 471,72$ & 2,39 & $\mathbf{a}$ & $2,51 \mathbf{a b}$ & -3261 & d & -3421 & $\mathbf{a b}$ \\
\hline $1 / 235,65$ & 2,17 & bc & $2,54 \mathbf{a b}$ & -2956 & bc & -3469 & $\mathbf{a b}$ \\
\hline $1 / 211,78$ & 2,18 & be & $2,47 \mathbf{a b}$ & -2972 & bc & -3374 & $\mathbf{a b}$ \\
\hline $1 / 103,23$ & 2,03 & cd & 2,72 a & -2775 & $\mathbf{a b}$ & -3713 & $\mathbf{b}$ \\
\hline $\mathrm{CV}(\%)$ & 2,40 & & 8,31 & $-2,40$ & & $-8,31$ & \\
\hline
\end{tabular}

- nas colunas, médias seguidas pela mesma letra, para cada solo, não diferem significativamente pelo teste de Tukey, ao nivel de $5 \%$ de probabididade 
Analisando-se as figuras 19 a 32 observa-se, para os quatro solos, que o aumento da relação $\mathrm{K} /(\mathrm{Ca}+\mathrm{Mg})$ no solo diminui o potencial de potássio e aumenta a energia livre de troca $(\Delta \bar{G})$. A diminuição do potencial de potássio é caracterizado pelo aumento nos valores da atividade de $\mathrm{K}$ em relação à atividade de $\mathrm{Ca}+\mathrm{Mg}$. Este efeito foi observado dentro de ambos os valores da relação $\mathrm{Ca} / \mathrm{Mg}$. As equações de regressões lineares e quadráticas entre as relações $\mathrm{K} /(\mathrm{Ca}+\mathrm{Mg})$ no solo e os dados de potencial de $\mathrm{K}$ e $\Delta \overline{\mathrm{G}}$, alcançaram coeficiente de determinação $\left(R^{2}\right)$ alto, como podem ser vistos nas figuras de 19 a 32 , com exceção das regressões após o cultivo do solo, pois como foi discutido anteriormente, os valores não foram significativos, não apresentando neste caso $\mathrm{R}^{2}$ com bons ajustes. Estão apresentados apenas para mostrar não ser um bom referencial a determinação do potencial de $\mathrm{Ke} \Delta \overline{\mathrm{G}}$ após o cultivo.

É importante chamar atenção, que apesar das diferenças estatísticas entre os valores de potencial de potássio e da energia livre de troca no solo $(\Delta \bar{G})$, a produção de grãos e de matéria seca de folhas, raizes, caule + ramos, vagem e matéria seca total (tabela 10) não apresentaram diferenças estatísticas, com exceção da produção de vagem e matéria seca total no LVA, entre a maior $(1 / 6,86)$ e a menor $(1 / 12,11)$ relação $\mathrm{K} /(\mathrm{Ca}+\mathrm{Mg})$ no solo.

Também foram realizadas análise de regressão, tendo como variável, independente os valores de potencial de $\mathrm{K}$ e $\Delta \bar{G}$, e como variável depdente os valores de produção de grãos e de matéria seca total, todavia, os coeficientes de correlações obtidos não foram significativos. 

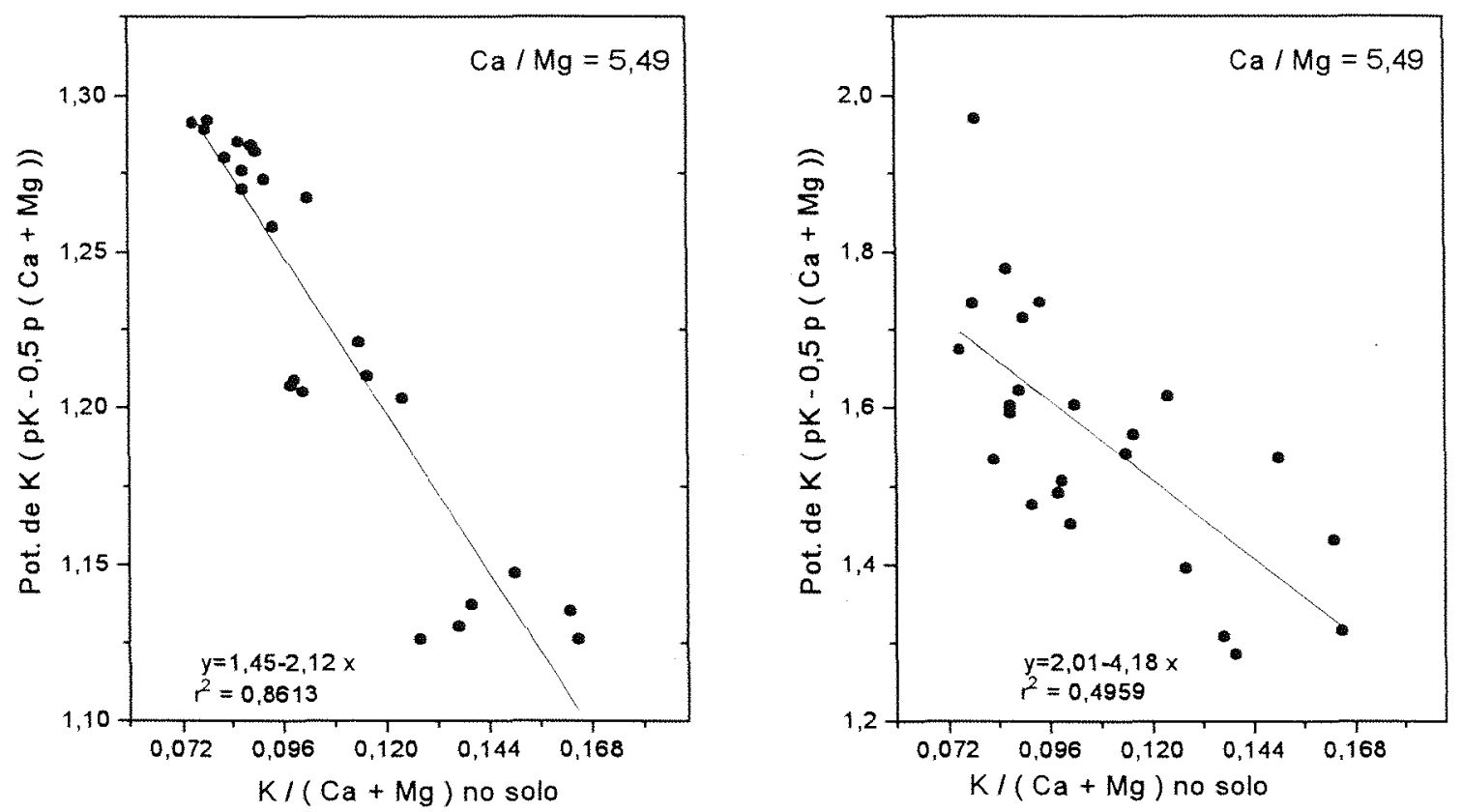

Figura 19. Potencial de potássio ( $\mathrm{pK}-0,5 \mathrm{p}(\mathrm{Ca}+\mathrm{Mg})$ ), antes e após o cultivo do solo em função das relações $\mathrm{K} /(\mathrm{Ca}+\mathrm{Mg})$, aplicadas no Latossolo Vermelho Amarelo.
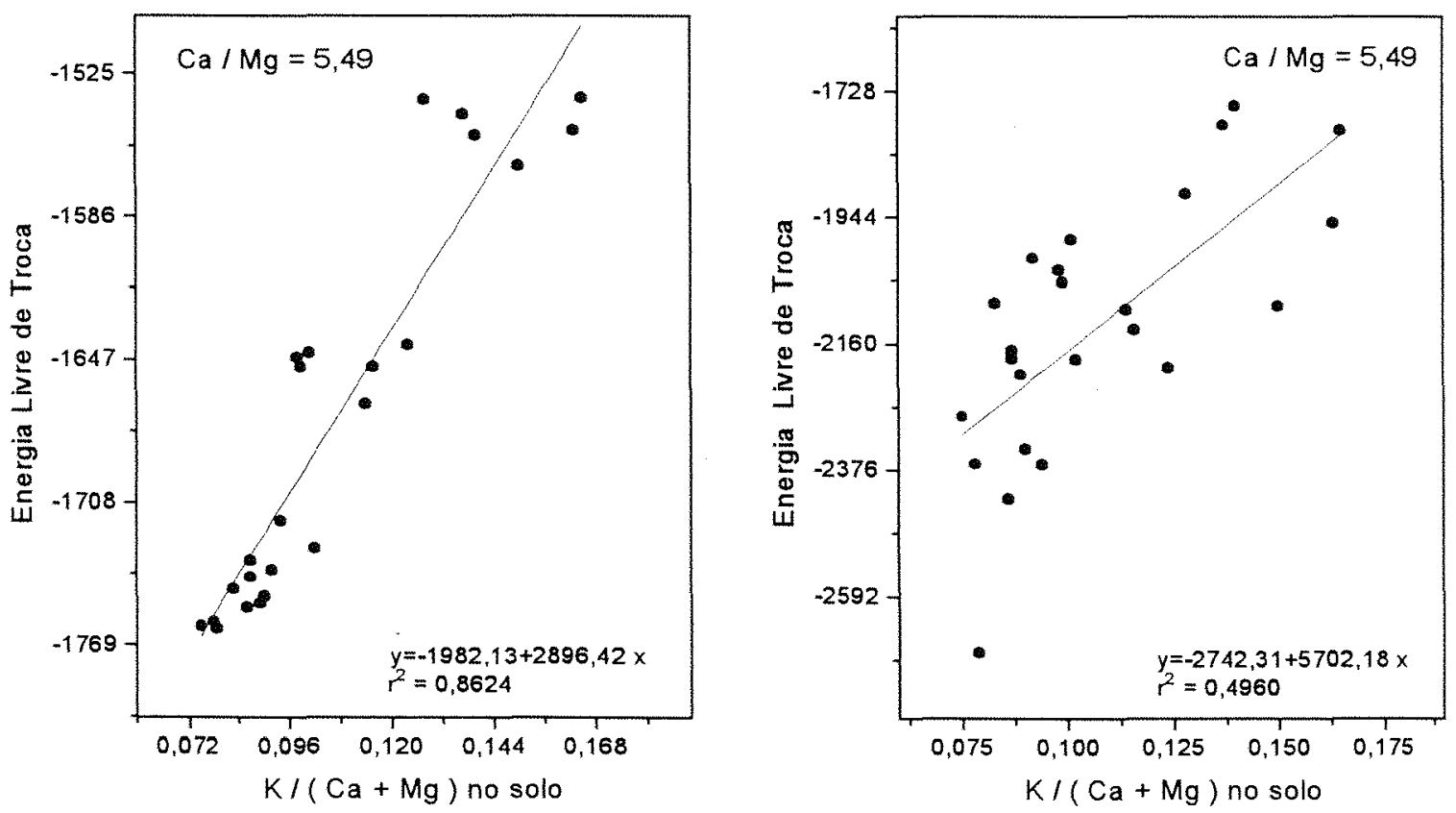

Figura 20. Energia livre de troca $\Delta \overline{\mathrm{G}}(1364 \log (\mathrm{aK} / \sqrt{a(C a+M g)}))$ antes e após o cultivo do solo, em função das relações $\mathrm{K} /(\mathrm{Ca}+\mathrm{Mg}$ ), aplicadas no Latossolo Vermelho Amarelo. 

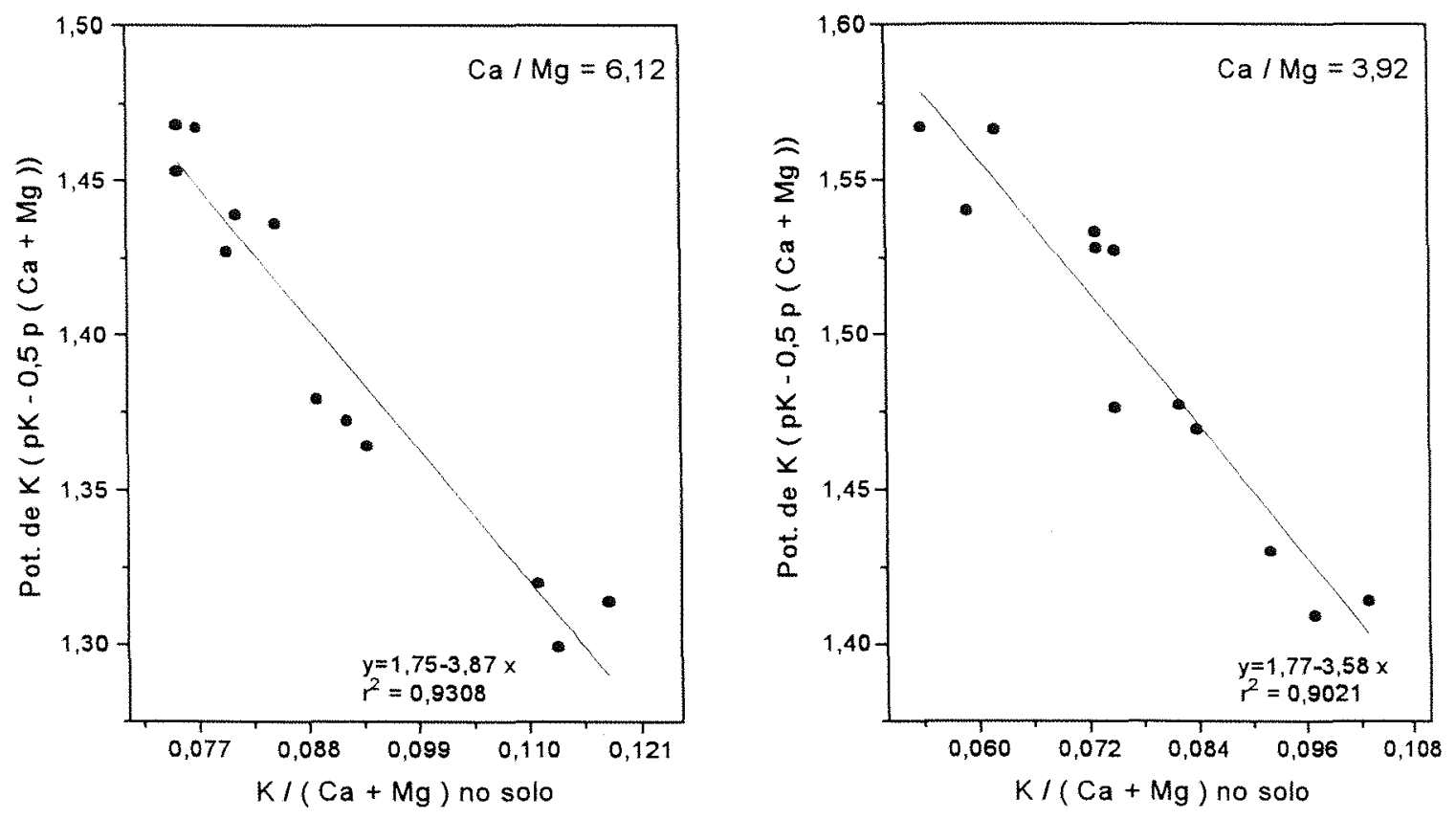

Figura 21. Potencial de potássio ( $\mathrm{pK}-0,5 \mathrm{p}(\mathrm{Ca}+\mathrm{Mg}))$, antes do cúltivo do solo, em função das relações $\mathrm{K} /(\mathrm{Ca}+\mathrm{Mg})$, aplicadas no Latossolo Amarelo.
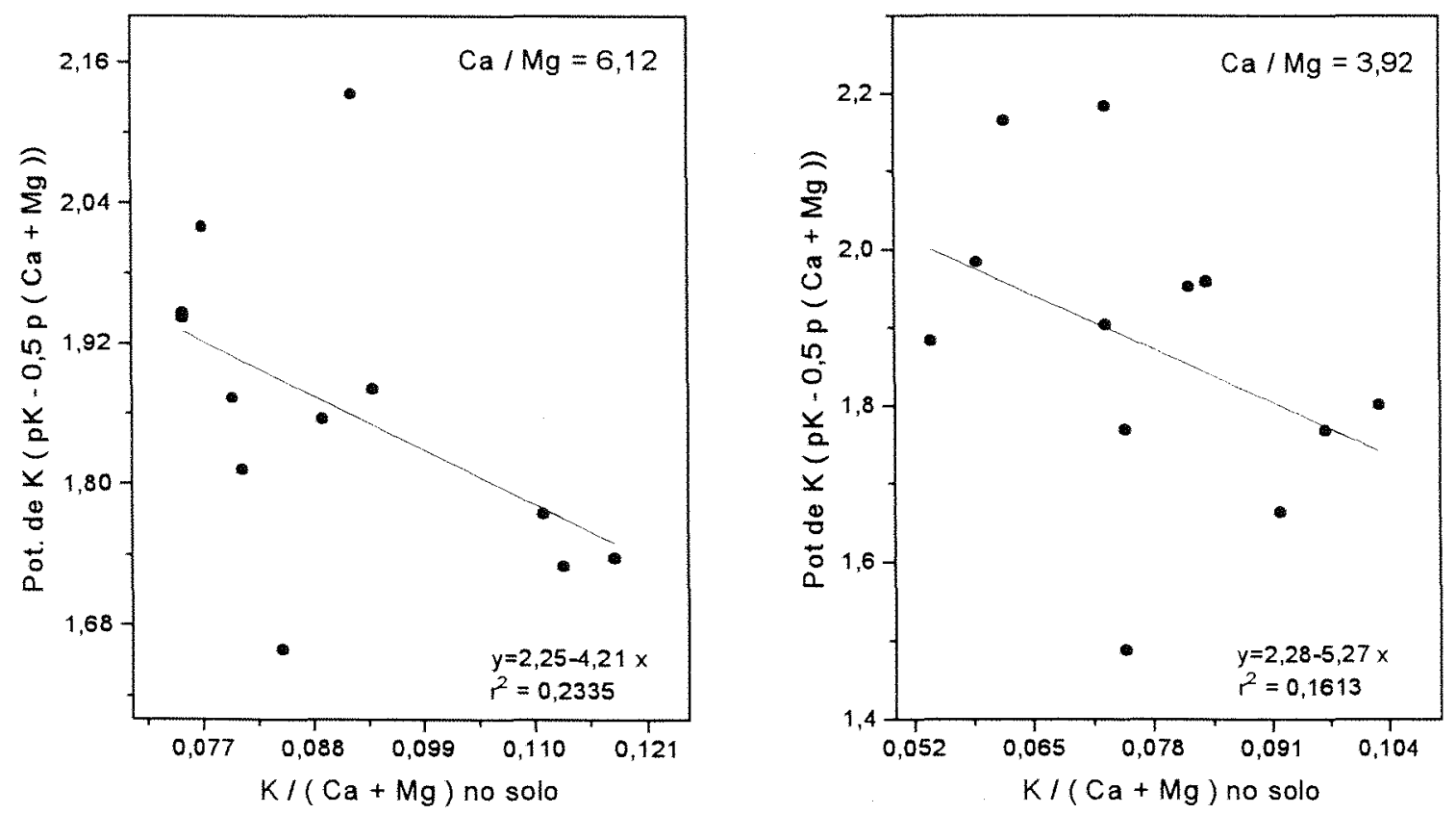

Figura 22. Potencial de potássio ( $\mathrm{pK}-0,5 \mathrm{p}(\mathrm{Ca}+\mathrm{Mg})$ ), após o cúltivo do solo, em função das relações $\mathrm{K} /(\mathrm{Ca}+\mathrm{Mg})$, aplicadas no Latossolo Amarelo. 

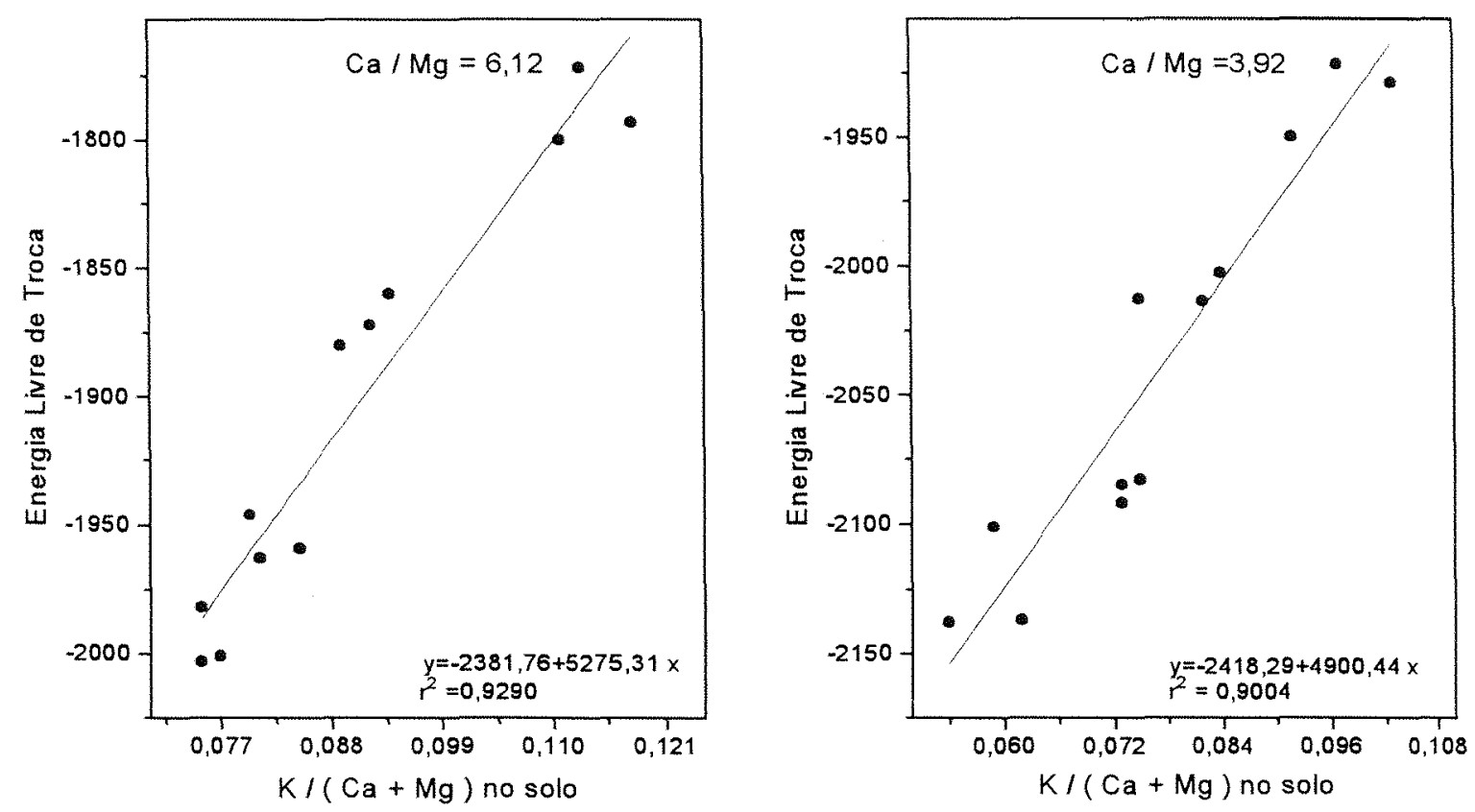

Figura 23. Energia livre de troca $\overline{D G}(1364 \log (\mathrm{aK} / \sqrt{a(C a+M g)}))$ antes do cultivo do solo, em função das relações $\mathrm{K} /(\mathrm{Ca}+\mathrm{Mg})$, aplicadas no Latossolo Amarelo.
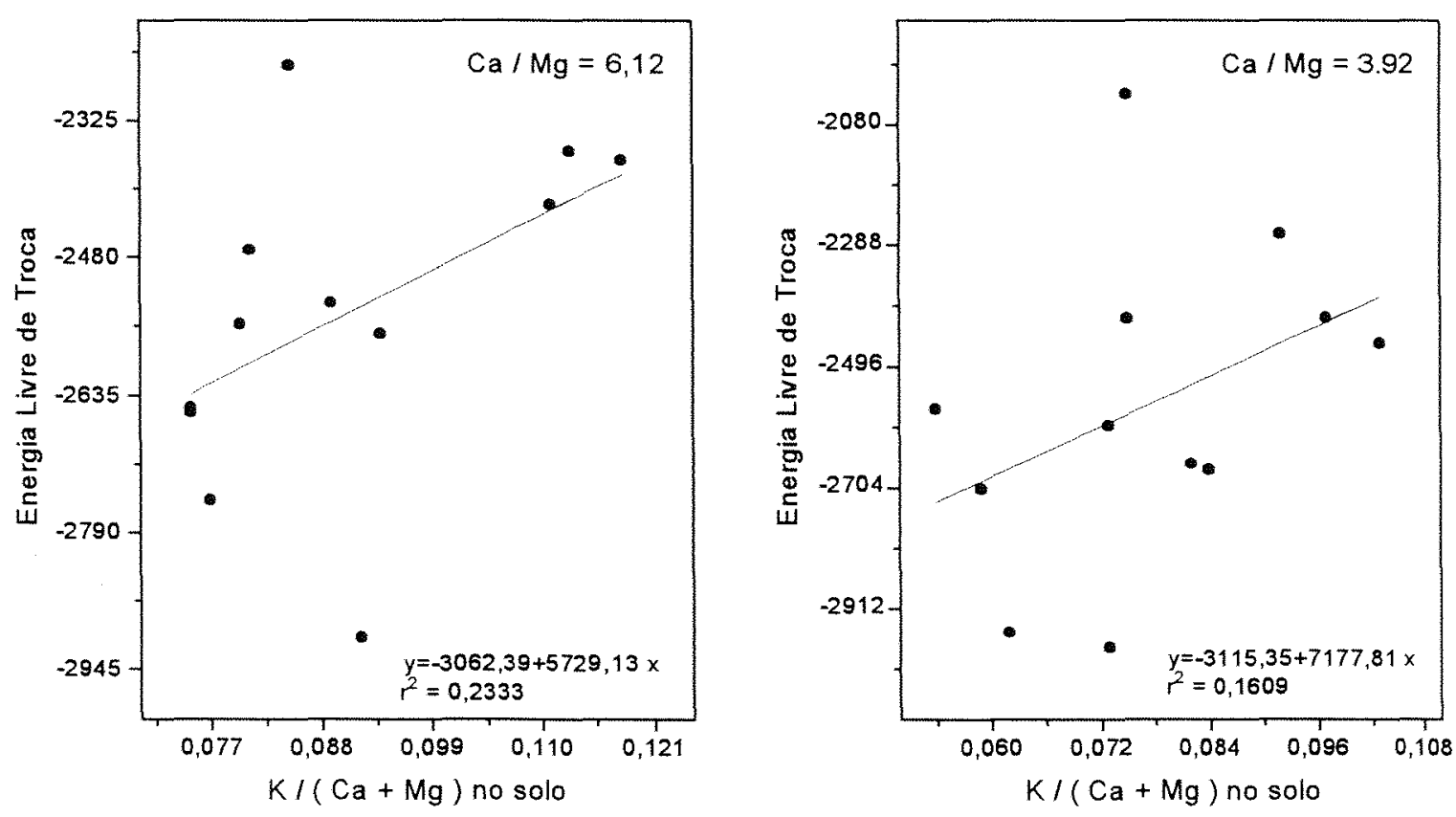

Figura 24. Energia livre de troca $\Delta \overline{\mathrm{G}}(1364 \log (\mathrm{aK} / \sqrt{a(C a+M g)}))$ após o cultivo do solo em função das relações $\mathrm{K} /(\mathrm{Ca}+\mathrm{Mg}$ ), aplicadas no Latossolo Amarelo. 

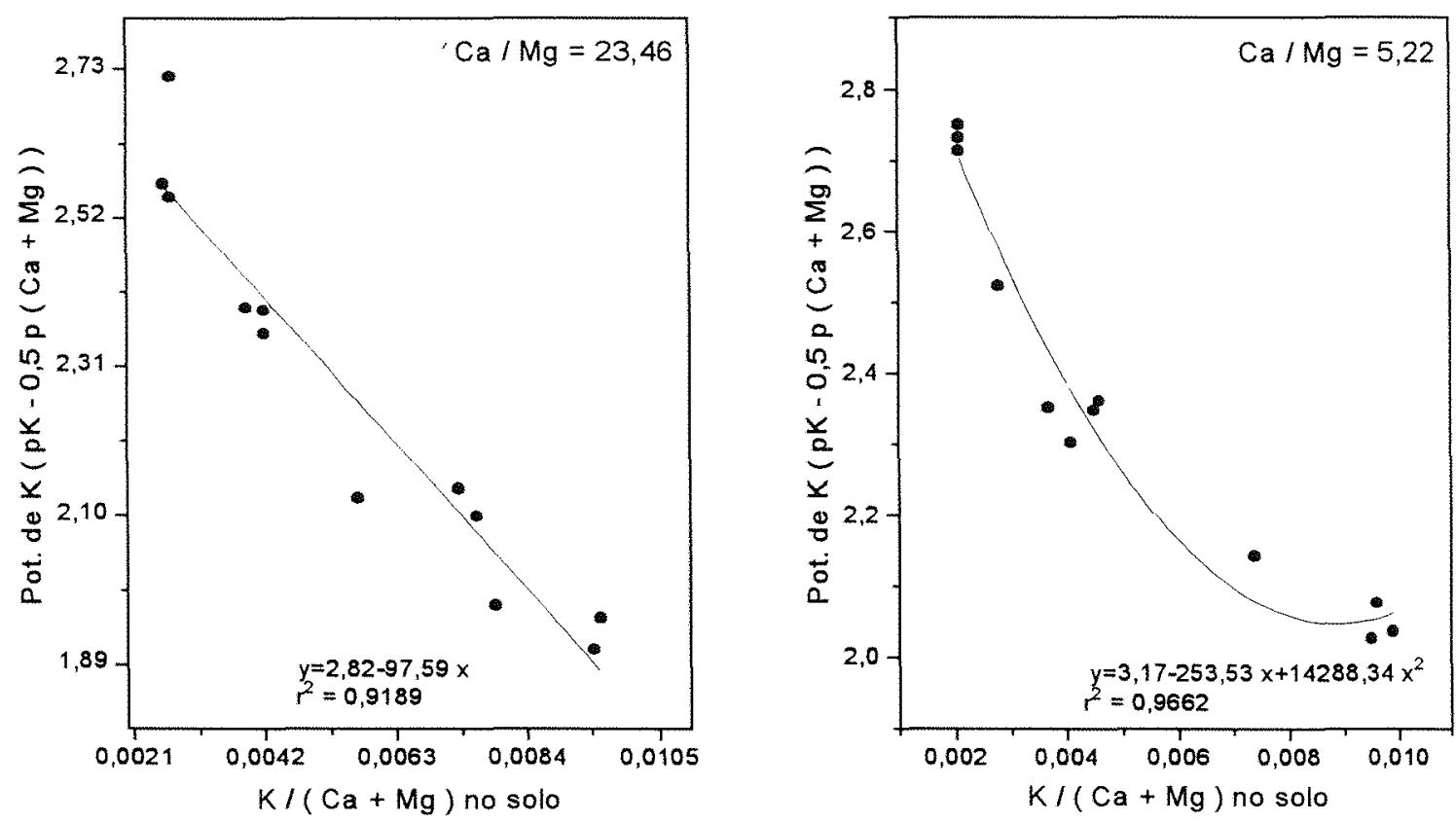

Figura 25. Potencial de potássio ( $\mathrm{pK}-0,5 \mathrm{p}(\mathrm{Ca}+\mathrm{Mg})$ ), antes do cúltivo do solo, em função das relações $\mathrm{K} /(\mathrm{Ca}+\mathrm{Mg})$, apicadas no Cambissolo Vértico.
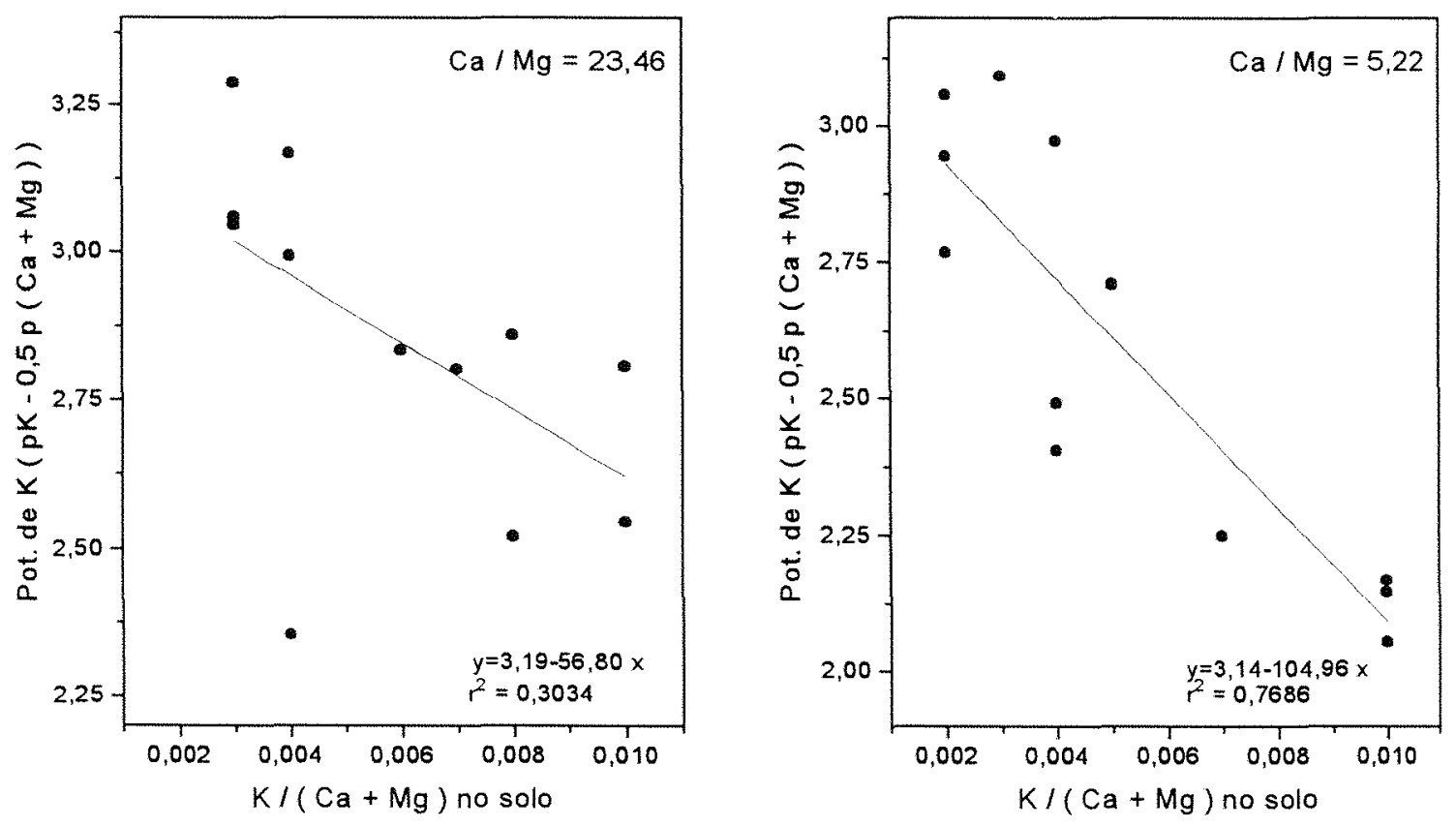

Figura 26. Potencial de potássio ( $\mathrm{pK}-0,5 \mathrm{p}(\mathrm{Ca}+\mathrm{Mg})$ ), após o cúltivo do solo, em função das relações $\mathrm{K} /(\mathrm{Ca}+\mathrm{Mg})$, apicadas no Cambissolo Vértico. 

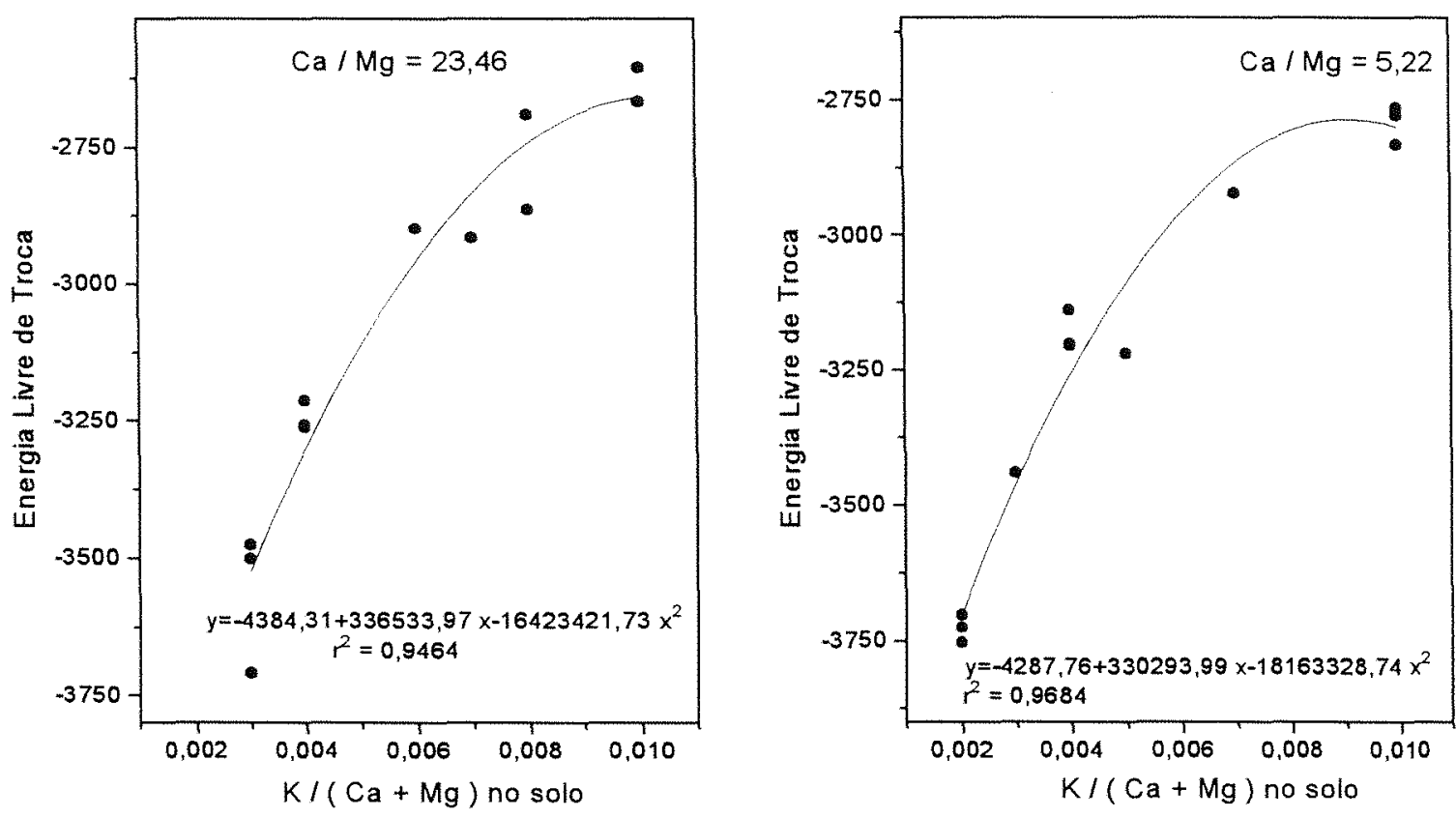

Figura 27. Energia livre de troca $\Delta \bar{G}(1364 \log (\mathrm{aK} / \sqrt{a(C a+M g)}))$ antes do cultivo do solo, em função das relações $\mathrm{K} /(\mathrm{Ca}+\mathrm{Mg}$ ), aplicadas no Cambissolo Vértico.
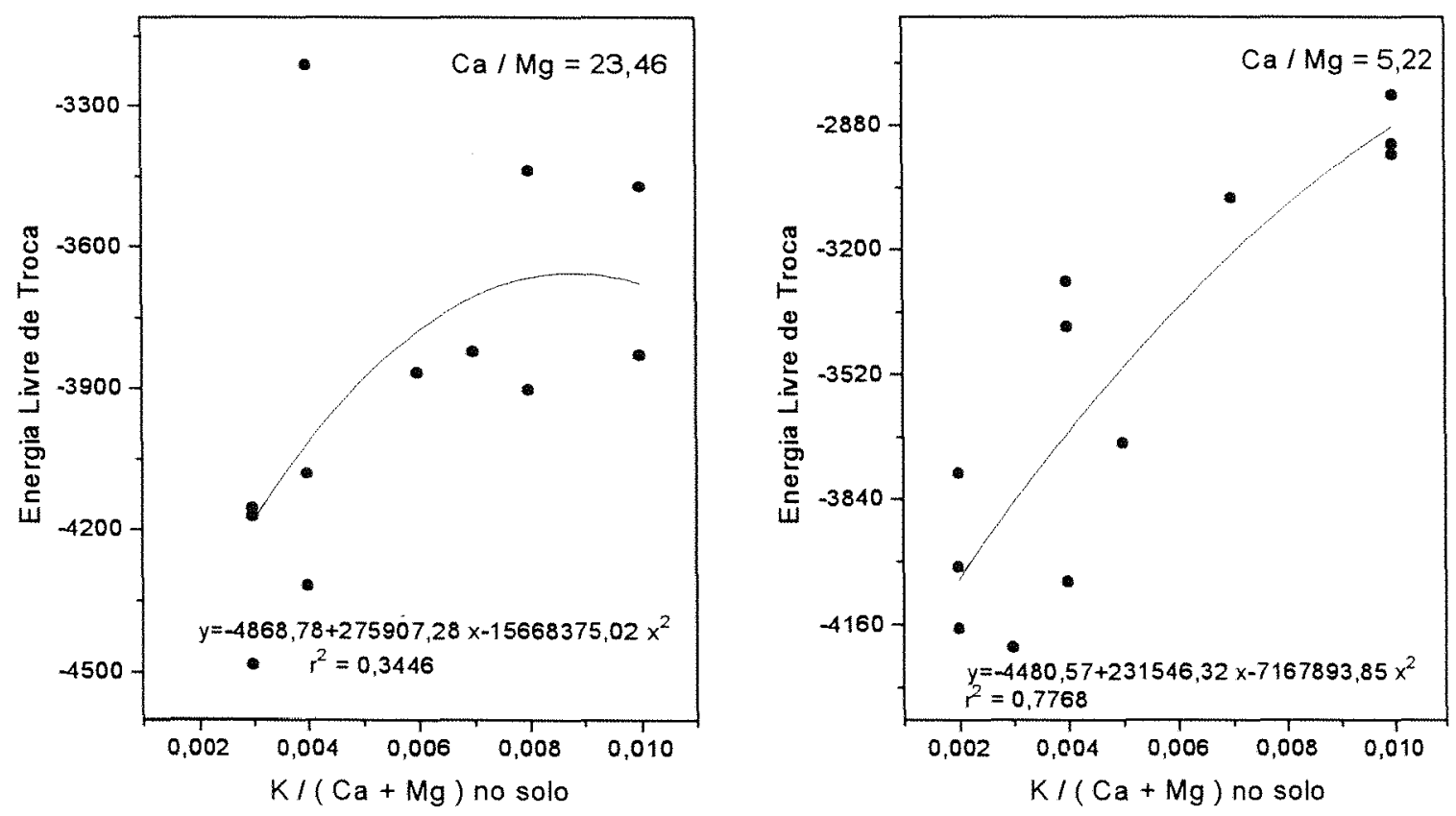

Figura 28. Energia livre de troca $\Delta \bar{G}(1364 \log (\mathrm{aK} / \sqrt{a(C a+M g)}))$ após o cultivo do solo em função das relações $\mathrm{K} /(\mathrm{Ca}+\mathrm{Mg})$, aplicadas no Cambissolo Vértico. 

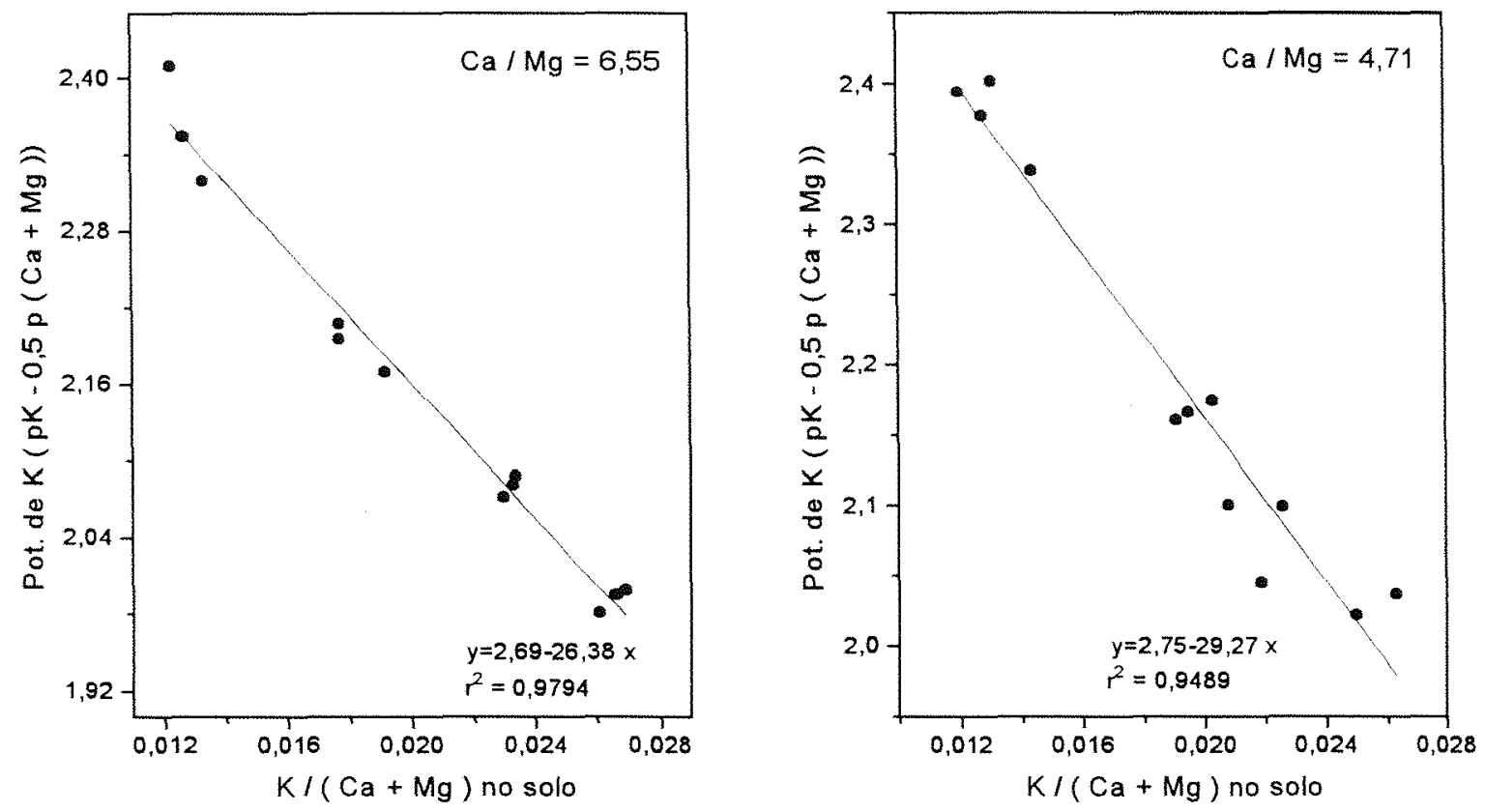

Figura 29. Potencial de potássio ( $\mathrm{pK}-0,5 \mathrm{p}(\mathrm{Ca}+\mathrm{Mg})$ ), antes do cúltivo do solo, em função das relações $\mathrm{K} /(\mathrm{Ca}+\mathrm{Mg})$, aplicadas no Cambissolo Latossólico.
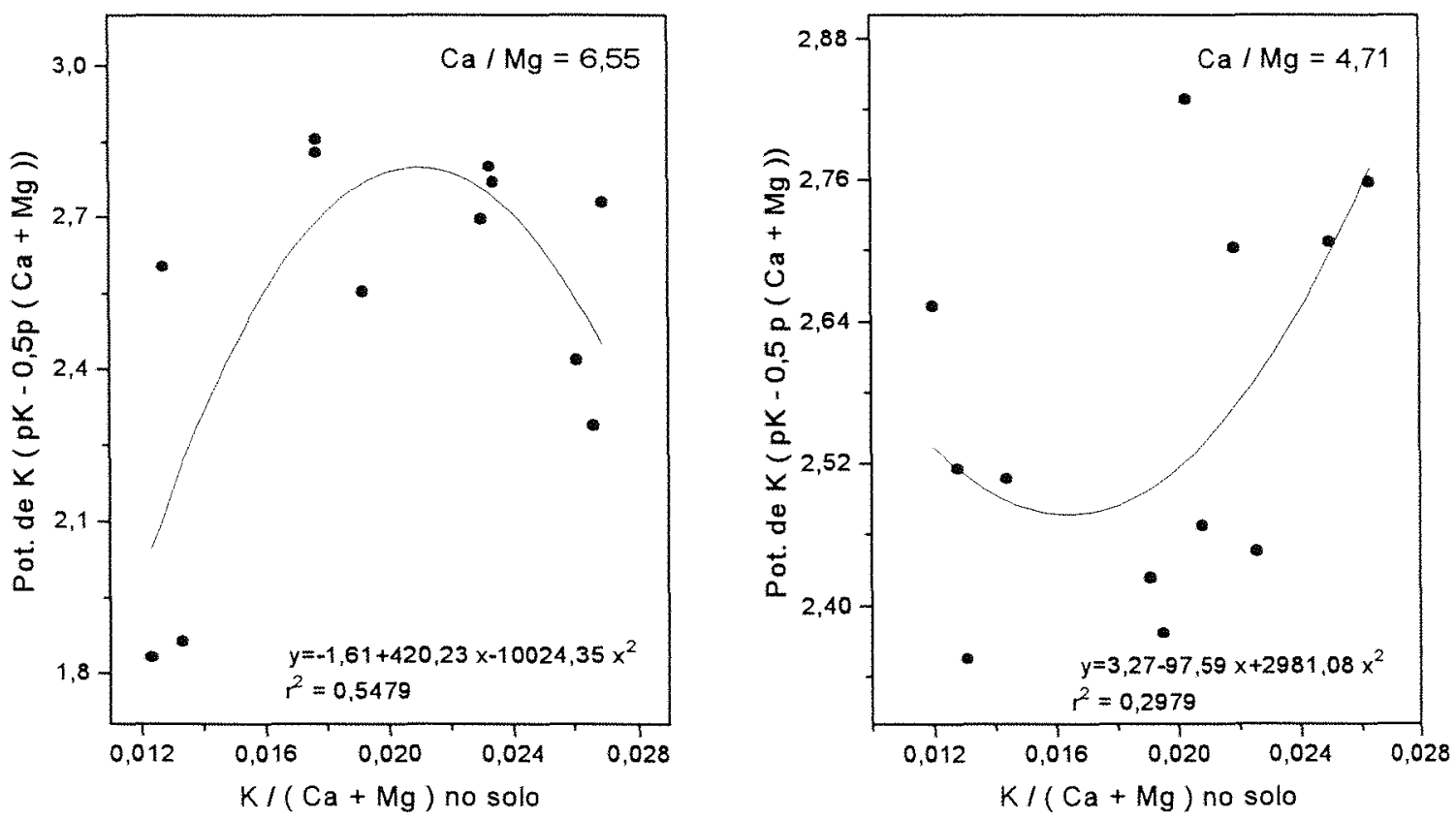

Figura 30. Potencial de potássio ( $\mathrm{pK}-0,5 \mathrm{p}(\mathrm{Ca}+\mathrm{Mg})$ ), após o cúltivo do solo, em função das relações $\mathrm{K} /(\mathrm{Ca}+\mathrm{Mg})$, aplicadas no Cambissolo Latossólico. 

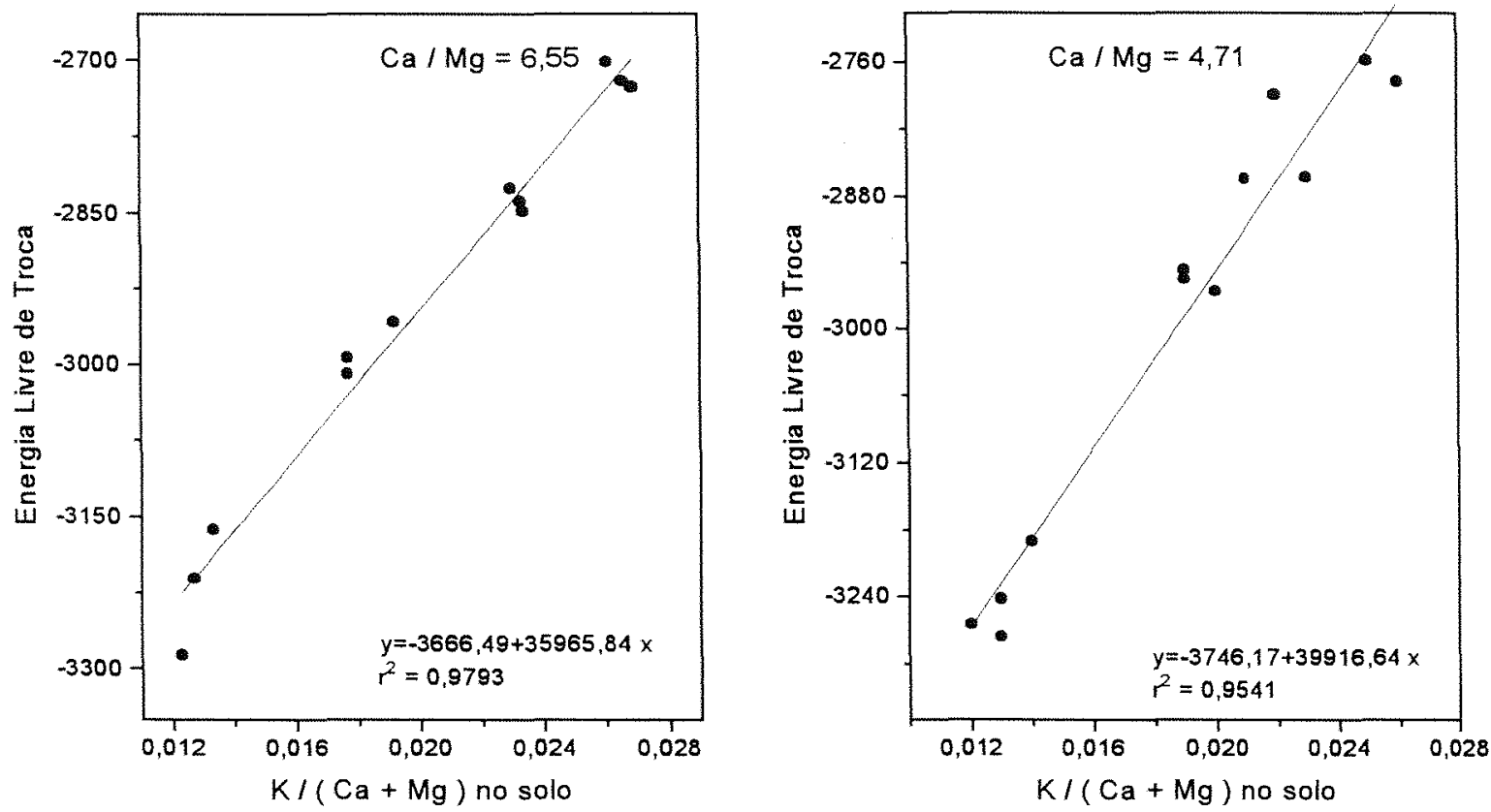

Figura 31. Energia livre de troca $\Delta \overline{\mathrm{G}}(1364 \log (\mathrm{aK} / \sqrt{a(C a+M g)}))$ antes do cultivo do solo, em função das relações $\mathrm{K} /(\mathrm{Ca}+\mathrm{Mg}$ ), aplicadas no Cambissolo Latossólico
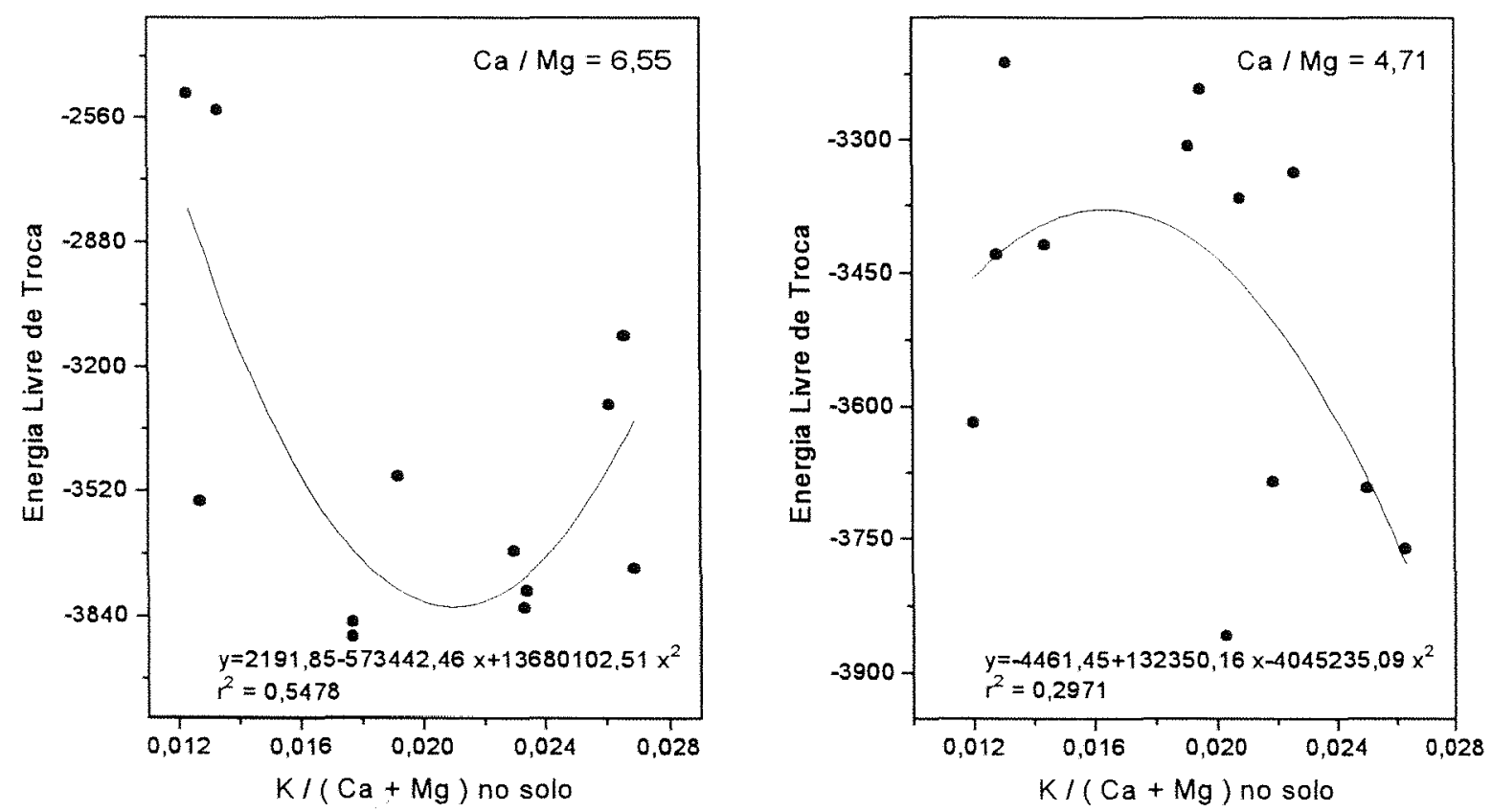

Figura 32. Energia livre de troca $\Delta \overline{\mathrm{G}}(1364 \log (\mathrm{aK} / \sqrt{a(C a+M g)}))$ após o cultivo do solo, em função das relações $\mathrm{K} /(\mathrm{Ca}+\mathrm{Mg})$, aplicadas no Cambissolo latossólico. 
Analisando a tabela 13 observa-se um aumento nas variações dos valores do potencial de $K$ entre antes e após o cultivo, dentro das diferentes relações $\mathrm{K} /(\mathrm{Ca}+\mathrm{Mg})$ nos solos, como também nota-se uma diminuição nos valores de $\Delta G$ nesse mesmo sentido.

WOODRUF (1955a) afirma que os valores de pk-0,5ca menores que 1,5 normalmente estão associados com absorção excessiva de potássio ou deficiência de cálcio, já os valores entre 1,8 e 2,2 representam equilíbrio adequado entre cálcio e potássio para nutrição das plantas. Chama atenção também o autor que para valores maiores que 2,6 ocorreria deficiência de potássio. Da mesma forma BULL (1986) observou deficiência de $K$ em valores de $p k-0,5 p(C a+M g)$ maiores que 2,6 para cultura de gramínea isolada e consorciadas e leguminosa consorciada. De acordo com os limites de potencial de $\mathrm{K}$ relatado no início deste capítulo, encontrou-se potencial de $K$ menor que 1,5 no LVA e LA, entre 1,8 e 2,2 no LA, CV e CL e maior que 2,6 e no CV e CL. Na condição desse trabalho, pela análise química de $K$ nas folhas do feijoeiro, pode-se afirmar não ter ocorrido absorção excessiva de potássio. Também não foi observado em nenhum momento deficiência de potássio e de cálcio, seja por sintoma visual ou através dos resultados de análise de solo e planta. Desta forma, nenhum destes critérios se enquadram para os solos estudados, dando a entender, serem outros os limites de potencial de potássio em solos calcáreos, que atenda os critérios comentados pela literatura. No caso específico de deficiência de potássio, pode-se deduzir que - valor limite para deficiência possivelmente seja superior a 2,6. Semelhantemente para energia livre de troca $(\Delta \bar{G})$ WOODRUF (1955a) e KRASAWNER (1971) relataram que solos são deficientes em potássio, quando $\triangle G$ for menor que -3500 cal/equivalente; o mesmo WOODRUF \& McINTOSH (1966) reformula o critério para -4000 cal/equivalente, e para BARROWS et al. (1967) o limite pode ser de -6000 cal/equivalente. Neste ensaio chegou-se até aproximadamente -4000 cal/equivalente e como foi comentado anteriormente não se observou deficiência de potássio. Caso venha acontecer deficiência de $K$ nesses solos, provavelmente o limite deve ser um valor menor que -4000 cal/equivalente. 


\subsubsection{Teores de K, Ca e Mg Trocáveis Recuperados Antes e Após o Cultivo dos Solos em Função das Relaçōes $\mathrm{K} /(\mathrm{Ca}+\mathrm{Mg})$ Aplicadas nos Solos}

Pela tabela 14, no solo LA, CV e CL onde nas quatro primeiras relações $\mathrm{K} /(\mathrm{Ca}+\mathrm{Mg})$ de cada solo, tem-se a relação $\mathrm{Ca} / \mathrm{Mg}$ originária dos solos, e nas quatro últimas a relação $\mathrm{Ca} / \mathrm{Mg}$ modificada pela adição de magnésio, verificase em ambos os solos, que a relação $\mathrm{Ca} / \mathrm{Mg}$ não influenciou o teor de potássio e cálcio trocável, com as médias não diferindo significativamente pelo teste de Tukey, ao nivel de $5 \%$ de probabilidade. Dado este que está de acordo com as informações de SOARES (1978). Todavia, como era de se esperar, influenciou significativamente o teor de magnésio trocável, principalmente antes do cultivo em função do magnésio, adicionado nas quatro últimas relações $\mathrm{K} /(\mathrm{Ca}+\mathrm{Mg})$ do solo, como comentado acima.

Observa-se também na tabela 14 , que o teor de potássio trocável antes do cultivo, dentro das duas relações $\mathrm{Ca} / \mathrm{Mg}$, diferem significativamente pelo teste de Tukey a nível de $5 \%$ de probabilidade, em função da elevação do nivel de potássio trocável, caracterizado pelo aumento na relação $\mathrm{K} /(\mathrm{Ca}+\mathrm{Mg})$ do solo, possivelmente os teores de potássio após o cultivo não diferiram significativamente, em decorrência da extação pelas plantas de feijão. Também, os teores de cálcio e magnésio antes e após o cultivo não apresentaram diferenças com o aumento da relação $\mathrm{K} /(\mathrm{Ca}+\mathrm{Mg})$ no solo. 
Tabela 14. Valores médios de potássio, cálcio e magnésio trocáveis $\left(\mathrm{mmol}_{\mathrm{C}} / \mathrm{dm}^{3}\right)$, recuperados antes e após o cultivo dos solos, em função das relações $\mathrm{K} /(\mathrm{Ca}+\mathrm{Mg})$ aplicadas no LVA, LA, CV e $\mathrm{CL}$.

\begin{tabular}{|c|c|c|c|c|c|c|}
\hline Relações & \multicolumn{2}{|c|}{ K } & \multicolumn{2}{|c|}{$\mathrm{Ca}$} & \multicolumn{2}{|c|}{$\mathbf{M g}$} \\
\hline $\mathrm{K} /(\mathrm{Ca}+\mathrm{Mg})$ & Antes & Após & Antes & Após & Antes & Após \\
\hline
\end{tabular}

\begin{tabular}{rrrrlrllllllll}
$\mathbf{1} / \mathbf{1 2 , 1 1}$ & 12,43 & $\mathbf{c}$ & 3,69 & $\mathbf{c}$ & 127,67 & $\mathbf{a}$ & 89,75 & $\mathbf{a}$ & 22,55 & $\mathbf{a}$ & 21,71 & $\mathbf{a}$ \\
$\mathbf{1 / 1 1 , 0 5}$ & 13,17 & $\mathbf{c}$ & 4,64 & $\mathbf{b c}$ & 123,67 & $\mathbf{a}$ & 79,55 & $\mathbf{a}$ & 21,88 & $\mathbf{a}$ & 19,77 & $\mathbf{b}$ \\
$\mathbf{1 / 9 , 2 4}$ & 15,42 & $\mathbf{b}$ & 5,90 & $\mathbf{b}$ & 120,53 & $\mathbf{a}$ & 82,75 & $\mathbf{a}$ & 21,93 & $\mathbf{a}$ & 20,46 & $\mathbf{a b}$ \\
$\mathbf{1 / 6 , 8 6}$ & 19,56 & $\mathbf{a}$ & 8,15 & $\mathbf{a}$ & 112,33 & $\mathbf{a}$ & 85,30 & $\mathbf{a}$ & 21,2 & $\mathbf{a}$ & 19,91 & $\mathbf{b}$ \\
\hline $\mathbf{C V}(\mathbf{\%})$ & 6,57 & 20,98 & 9,22 & & 11,64 & & 3,38 & 4,44 \\
\hline
\end{tabular}

\section{Latossolo Amarelo}

\begin{tabular}{|c|c|c|c|c|c|c|c|c|c|c|c|c|}
\hline $1 / 13,22$ & 7,31 & de & 1,47 & c & 83,27 & $\mathbf{a}$ & 59,60 & $\mathbf{a b}$ & 13,36 & b & 9,46 & c \\
\hline $1 / 12,25$ & 7,80 & cd & 1,80 & bc & 81,93 & $\mathbf{a}$ & 64,53 & $\mathbf{a b}$ & 13,58 & b & 12,81 & abc \\
\hline $1 / 10,92$ & 8,65 & bc & 2,09 & $\mathbf{a b c}$ & 81,33 & $\mathbf{a}$ & 65,47 & $\mathbf{a b}$ & 13,14 & b & 11,13 & abc \\
\hline 118,80 & 11,09 & $\mathbf{a}$ & 2,82 & $\mathbf{a b}$ & 83,67 & $\mathbf{a}$ & 64,07 & $\mathbf{a b}$ & 13,92 & b & 10,30 & bc \\
\hline $1 / 17,10$ & 6,09 & $\mathbf{e}$ & 1,96 & abc & 83,87 & $\mathbf{a}$ & 68,13 & $\mathbf{a}$ & 20,26 & $\mathbf{a}$ & 15,87 & $\mathbf{a}$ \\
\hline $1 / 13,59$ & 7,55 & cd & 2,41 & abc & 81,13 & $\mathbf{a}$ & 66,53 & $\mathbf{a b}$ & 21,49 & $\mathbf{a}$ & 16,14 & $\mathbf{a}$ \\
\hline $1 / 12,45$ & 8,04 & cd & 3,02 & $\mathbf{a}$ & 79,87 & $\mathbf{a}$ & 53,33 & $\mathbf{b}$ & 20,26 & $\mathbf{a}$ & 16,43 & $\mathbf{a}$ \\
\hline $1 / 10,26$ & 9,63 & b & 2,80 & $\mathbf{a b}$ & 78,20 & $\mathbf{a}$ & 53,13 & b & 20,60 & $\mathbf{a}$ & 15,31 & $\mathbf{a b}$ \\
\hline $\operatorname{CV}(\%)$ & 5,41 & & 17,13 & & 5,60 & & 7,82 & & 6,68 & & 14,30 & \\
\hline
\end{tabular}

\section{Cambissolo Vértico}

\begin{tabular}{|c|c|c|c|c|c|c|c|c|c|c|c|c|}
\hline $1 / 377,51$ & 1,15 & $\mathbf{e}$ & 0,64 & b & 414,67 & $\mathbf{a}$ & 445,33 & $\mathbf{a}$ & 19,48 & b & 19,21 & b \\
\hline $1 / 242,21$ & 1,78 & de & 0,66 & b & 412,67 & $\mathbf{a}$ & 389,67 & $\mathbf{a b}$ & 18,48 & $\mathbf{b}$ & 18,93 & b \\
\hline $1 / 147,99$ & 3,27 & bc & 1,08 & b & 465,33 & $\mathbf{a}$ & 417,67 & $\mathbf{a b}$ & 18,59 & $\mathbf{b}$ & 20,88 & b \\
\hline $1 / 112,27$ & 4,26 & $\mathbf{a b}$ & 1,55 & $\mathbf{b}$ & 460,00 & $\mathbf{a}$ & 398,67 & $\mathbf{a b}$ & 18,26 & $\mathbf{b}$ & 19,49 & b \\
\hline $1 / 471,72$ & 1,04 & e & 0,88 & $\mathbf{b}$ & 412,67 & $\mathbf{a}$ & 368,67 & $\mathbf{b}$ & 77,93 & $\mathbf{a}$ & 61,24 & $\mathbf{a}$ \\
\hline $1 / 235,65$ & 2,24 & cde & 0,89 & $\mathbf{a b}$ & 435,33 & $\mathbf{a}$ & 355,00 & $\mathbf{b}$ & 90,18 & $\mathbf{a}$ & 67,92 & $\mathbf{a}$ \\
\hline $1 / 211,78$ & 2,56 & cd & 1,74 & $\mathbf{b}$ & 458,67 & $\mathbf{a}$ & 402,00 & $\mathbf{a b}$ & 83,50 & $\mathbf{a}$ & 65,41 & $\mathbf{a}$ \\
\hline $1 / 103,23$ & 4,72 & $\mathbf{a}$ & 3,49 & $\mathbf{a}$ & 409,33 & $\mathbf{a}$ & 389,67 & $\mathbf{a b}$ & 77,93 & $\mathbf{a}$ & 72,09 & $\mathbf{a}$ \\
\hline \multirow[t]{2}{*}{ CV $(\%)$} & 16,98 & & 41,11 & & 10,47 & & 5,94 & & 9,27 & & 13,54 & \\
\hline & \multicolumn{12}{|c|}{ Cambissolo Latossólico } \\
\hline $1 / 377,51$ & 1,87 & d & 1,05 & $\mathbf{a}$ & 127,00 & $\mathbf{a}$ & 81,87 & $\mathbf{a}$ & 19,21 & c & 10,86 & $\mathbf{a}$ \\
\hline $1 / 242,21$ & 2,76 & c & 1,03 & $\mathbf{a}$ & 131,67 & $\mathbf{a}$ & 91,93 & $\mathbf{a}$ & 20,04 & c & 16,70 & $\mathbf{a}$ \\
\hline $1 / 147,99$ & 3,50 & abc & 1,32 & $\mathbf{a}$ & 130,83 & $\mathbf{a}$ & 96,33 & $\mathbf{a}$ & 20,04 & c & 27,28 & $\mathbf{a}$ \\
\hline $1 / 112,27$ & 4,03 & $\mathbf{a}$ & 1,15 & $\mathbf{a}$ & 131,50 & $\mathbf{a}$ & 80,20 & $\mathbf{a}$ & 20,32 & c & 14,20 & $\mathbf{a}$ \\
\hline $1 / 471,72$ & 1,94 & d & 1,62 & $\mathbf{a}$ & 127,00 & $\mathbf{a}$ & 85,93 & $\mathbf{a}$ & 26,72 & $\mathbf{b}$ & 23,10 & $\mathbf{a}$ \\
\hline $1 / 235,65$ & 3,13 & bc & 1,37 & $\mathbf{a}$ & 130,50 & $\mathbf{a}$ & 91,60 & $\mathbf{a}$ & 28,95 & $\mathbf{a}$ & 24,50 & $\mathbf{a}$ \\
\hline $1 / 211,78$ & 3,03 & c & 1,28 & $\mathbf{a}$ & 129,50 & $\mathbf{a}$ & 86,00 & $\mathbf{a}$ & 27,56 & $\mathbf{a b}$ & 21,71 & $\mathbf{a}$ \\
\hline $1 / 103,23$ & 3,90 & $\mathbf{a b}$ & 1,25 & $\mathbf{a}$ & 132,67 & $\mathbf{a}$ & 91,87 & $\mathbf{a}$ & 27,56 & $\mathbf{a b}$ & 25,33 & $\mathbf{a}$ \\
\hline $\mathrm{CV}(\%)$ & 9,26 & & 28,63 & & 2,07 & & 10,37 & & 2,37 & & 29,30 & \\
\hline
\end{tabular}

nas colunas, médias seguidas pela mesma letra, para cada solo, não diferem significativamente pelo teste de Tukey, ao nível de $5 \%$ de probabilidade. 


\subsection{Diagnose por Subtração de $P$, S e Micronutrientes}

\subsubsection{Produção de Grãos e Matéria Seca}

O efeito dos tratamentos sobre a produção de grãos e matéria seca de: folha, raízes, caule + ramos, vagem e total podem ser vistos nas tabelas 15 e 16, já na tabela 17 visualiza-se a produção relativa de grãos. Vê-se, de uma forma geral, que as médias não diferem significativamente pelo teste de Tukey, ao nivel de $5 \%$ de probabilidade, com pequenas exceções. Possivelmente, isto ocorreu em função do alto coeficiente de variação do ensaio. Todavia, é conveniente chamar atenção, para alguns pontos que possam ter contribuido para este alto coeficiente:

1. O péssimo estado de manutenção da casa de vegetação, com problemas no teto, trazendo no período chuvoso sérios transtornos.

2. Presença na casa de vegetação de plantas hospedeiras do vírus Mosaico Dourado (VMD), apesar de pulverizações semanais, no final do ciclo as plantas apresentaram-se afetadas.

3. Pode-se ainda admitir, que para produções baixas como as do ensaio, normalmente o C.V. é alto.

Desta forma, onde não existir diferenças estatísticas, será comentado as tendências dos dados.

Observa-se na tabela 15, no LVA, diferença estatística na produção de grãos, entre o tratamento com omissão de fósforo e os tratamentos com omissão de boro e zinco. Todavia, para o LA e para $\mathrm{CV}$ e CL na tabela 16, o tratamento menos fósforo não difere estatisticamente dos demais. Pela tabela 17 , na produção relativa, verifica-se que o tratamento com omissão do fósforo apresentou redução em ambos os solos, com a maior redução no $\mathrm{CV}$, o que é explicado pelo seu menor teor de fósforo em relação aos demais solos (tabelas 8 e 31). De acordo com o que foi discutido no item 4.1.3. Análises Químicas, verifica-se, que os teores de fósforo para todos os solos é considerado de médio a alto pelos extratores, resina, Mehlich, Olsem. Sendo no extrator Bray 1 os teores considerados baixos no LVA, LA e CV e médio no $\mathrm{CL}$. Isto sugere, possivelmente, ser o extrator Bray o mais indicado para os solos calcários de Irecê, uma vez que além da redução na produção de grãos em relação ao tratamento completo, durante todo o ciclo da cultura, em ambos os solos, as 
plantas apresentaram sintomas de deficiência de fósforo. É importante chamar atenção que no final do ciclo, observou-se sintomas de deficiência de fósforo também nos tratamentos completos do LVA, LA e CL, com maior predominância no solo LA. No LVA, a produção de grãos no tratamento menos enxofre, difere significativamente pelo teste de Tukey, ao nivel de $5 \%$ de probabilidade, dos tratamentos menos boro e menos zinco. No LA, CV e CL não ocorreu diferenças estatísticas. Todavia, observese na tabela 17 , que na produção relativa de grãos, ocorre uma redução em relação ao tratamento completo em todos os solos, o que é justificado pelo sintoma de deficiência nas folhas durante o ciclo da cultura. Apesar dos teores de enxofre dos solos encontra-se acima do nivel critico citado no item 4.1.3 Análises Químicas, observa-se que esses solos respondem a aplicação de enxofre. Sendo possivelmente, mais alto os niveis criticos de enxofre para os solos calcários de Irecê.

O tratamento com omissão de boro, diferiu significativamente no LVA dos tratamentos com omissão de enxofre, fósforo e testemunha, não diferindo nos demais solos. Na produção relativa de grãos (tabela 17), detecta-se que a omissão de boro no LVA e LA provocou um aumento na produção relativa e no $\mathrm{CV}$ e $\mathrm{CL}$ praticamente igualou-se ao tratamento completo. Pressupõe-se, que este aumento na produção relativa no LVA e LA, seja função de uma possivel toxicidade em função da aplicação de boro na adubação de plantio, pois foi verificado durante o cultivo amarelamento e margens necróticas nas folhas primárias, apesar dos teores de boro nas folhas (tabela 24) não serem considerados tóxicos (MALAVOLTA, 1989; ELHUSNY, 1992).

A produção de grãos no tratamento menos cobre no LVA, difere estatisticamente do tratamento menos zinco, não apresentando diferenças estatísticas no $L A, C V$ e CL (tabelas 15 e 16). Todavia, a produção relativa na tabela 17 , mostra uma redução no tratamento com omissão de cobre em relação ao tratamento completo no solo LVA e CV, um aumento no solo LA e uma produção relativa praticamente semelhante no $C L$. Visualiza-se na tabela 31 , que o solo LA é o que possui menor teor de cobre, e foi o que apresentou aumento na produção relativa, provavelmente o nivel critico de cobre neste solo seja mais baixo que nos demais, provocando com a adubação de plantio uma possivel toxicidade de cobre. Idéia essa, sustentada pela ocorrência de clorose internerval seguidas de necrose e desfolhamento precoce durante o cultivo do feijoeiro, semelhante aos sintomas 
descritos por MALAVOLTA et al. (1989). Apesar dos teores de cobre nas folhas (tabela 24) não serem considerados tóxicos.

No LVA, o tratamento com omissão de ferro diferiu significativamente pelo teste de Tukey, ao nível de $5 \%$ de probabilidade do tratamento com omissão de zinco, no LA, CV e CL não ocorreu diferença estatistica entre os tratamentos. Ao observar o solo LVA na tabela 17, percebe-se, no tratamento menos ferro, uma redução na produção relativa de grãos e praticamente para o $L A, C V$ e $C L$ as produções relativas do tratamento menos ferro assemelham-se ao tratamento completo. Os teores de ferro em ambos os solos, encontram-se bem acima do nível crítico de $3,8 \mathrm{mg} / \mathrm{dm}^{3}$, encontrado por ELGALA et al. (1986), em experimentos conduzidos em vasos com solos calcários do Egito, usando como extrator o DTPA, o mesmo usado nesse ensaio. Além dos teores contidos na tabela 31, o experimento foi adubado com Fe na adubação de plantio, exceto no tratamento com omissão de ferro. Apesar, desse alto teor de $\mathrm{Fe}$ nos solos estudados, não pode-se admitir problema de toxidez, uma vez que não ocorreu diferença significativa entre a produção de grãos no tratamento com omissão de ferro e o tratamento completo (tabelas 15, 16 e 17). Paradoxalmente o que se observou foi clorose das folhas novas, seguida de um leve branqueamento, todavia, não se pode de forma nenhuma afirmar que os solos são deficientes em ferro, pois, segundo MENGEL \& GEURTZEN (1986) a deficiência de ferro em plantas desenvolvidas em solos calcários, muitas vezes é confundida com o efeito das altas concentrações de carbonatos e $\mathrm{Ca}^{2+}$ sobre a disponibilidade de ferro. Tem sido demonstrado que o efeito observado pode ser causado por excesso de $\mathrm{HCO}_{3}$, cujas as altas concentrações provocam uma inibição na capacidade de redução da raiz, absorção de $\mathrm{Fe}$, translocação as folhas $\mathrm{e}$ imobilização do ferro no interior das plantas. Pela Tabela 15, observa-se no LVA que o tratamento menos manganês difere estatisticamente do tratamento testemunha, entretanto não difere de nenhum tratamento nos demais solos (tabela 16). Observando a tabela 17, verifica-se no $L A$, um aumento na produção relativa de grãos no tratamento com omissão de manganês em relação ao tratamento completo. Já para os solos CV e CL ocorre uma redução e no LVA a produção relativa de grãos é praticamente semelhante ao do tratamento completo. A redução na produção relativa sugere ocorrer possivelmente no $\mathrm{CV}$ e $\mathrm{CL}$ deficiência de manganês. Como os teores de manganês nesses solos são considerados altos, essa deficiência segundo MALAVOLTA \& MURAOKA (1991) ocorre em solos com pH acima de 6, devido a 
formação de óxidos de $\mathrm{Mn}$ insolúveis, chama ainda atenção os autores que a redução na disponibilidade de manganês é de 100 vezes para aumento de uma unidade de $\mathrm{pH}$ do solo. Segundo os mesmos, desbalanços em relação a cálcio, magnésio e ferro podem causar a deficiência de manganês. VOSE \& JONES (1963) afirmam não ser simples a elevação do $\mathrm{pH}$ responsável pela deficiência de manganês, trabalhando com trevo, comprovaram o efeito negativo do cálcio na absorção do manganês. $A$ produção relativa alta no tratamento com omissão de manganês em relação ao tratamento completo, sugere para o LA a possibilidade de toxicidade de manganês nesse solo. Apesar, dos teores nas folhas do feijoeiro serem considerados adequados (MALAVOLTA, 1989). E o teor de manganês no solo LA ser bem inferior ao teor do solo $\mathrm{CL}$.

Na produção de grãos do LVA na tabela 15 , percebe-se que o tratamento menos zinco diferiu significativamente pelo teste de Tukey, ao nivel de $5 \%$ de probabilidade dos tratamentos testemunha, com omissão de fósforo, enxofre, cobre e ferro. Não diferindo de nenhum tratamento nos demais solos. A produção relativa de grãos, mostra um aumento no tratamento com omissão de zinco em relação ao tratamento completo no solo LVA e LA e uma redução no $\mathrm{CV}$ e $\mathrm{CL}$ (tabela 17). Esta redução induz a uma deficiência de zinco no solo $\mathrm{CV}$, que foi onde ocorreu a maior redução, o que é justificado, pois, o solo $\mathrm{CV}$ é o que possui menor teor de zinco, e apresentou também em todas repetições do tratamento, sintoma de deficiência de zinco muito visivel durante o cultivo. Considerando os teores de zinco dos solos mais os teores utilizados na adubação de plantio, possivelmente, essa deficiência seja em razão de formação de hidróxidos e carbonatos de zinco de baixa solubilidade em $\mathrm{pH}$ elevado o que provoca um decréscimo na absorção de zinco (LINDSAY, 1972). Da mesma forma, segundo CHAUDHRY \& LONERAGAN (1972) o efeito direto do cálcio provoca diminuição na absorção de zinco por plantas de trigo, é como esses solos são ricos em cálcio isto é provável de ter acontecido. $O$ aumento da produção relativa no tratamento menos zinco, no solo LA mostra a possibilidade de ter ocorrido toxicidade de zinco uma vez que os teores de zinco nesses solos estão acima do nivel crítico e a adubação de plantio poderá ter causado essa toxicidade nos solos. Apesar, dos teores de zinco nas folhas do feijoeiro encontrar-se na faixa adequada (MALAVOLTA, 1989). 


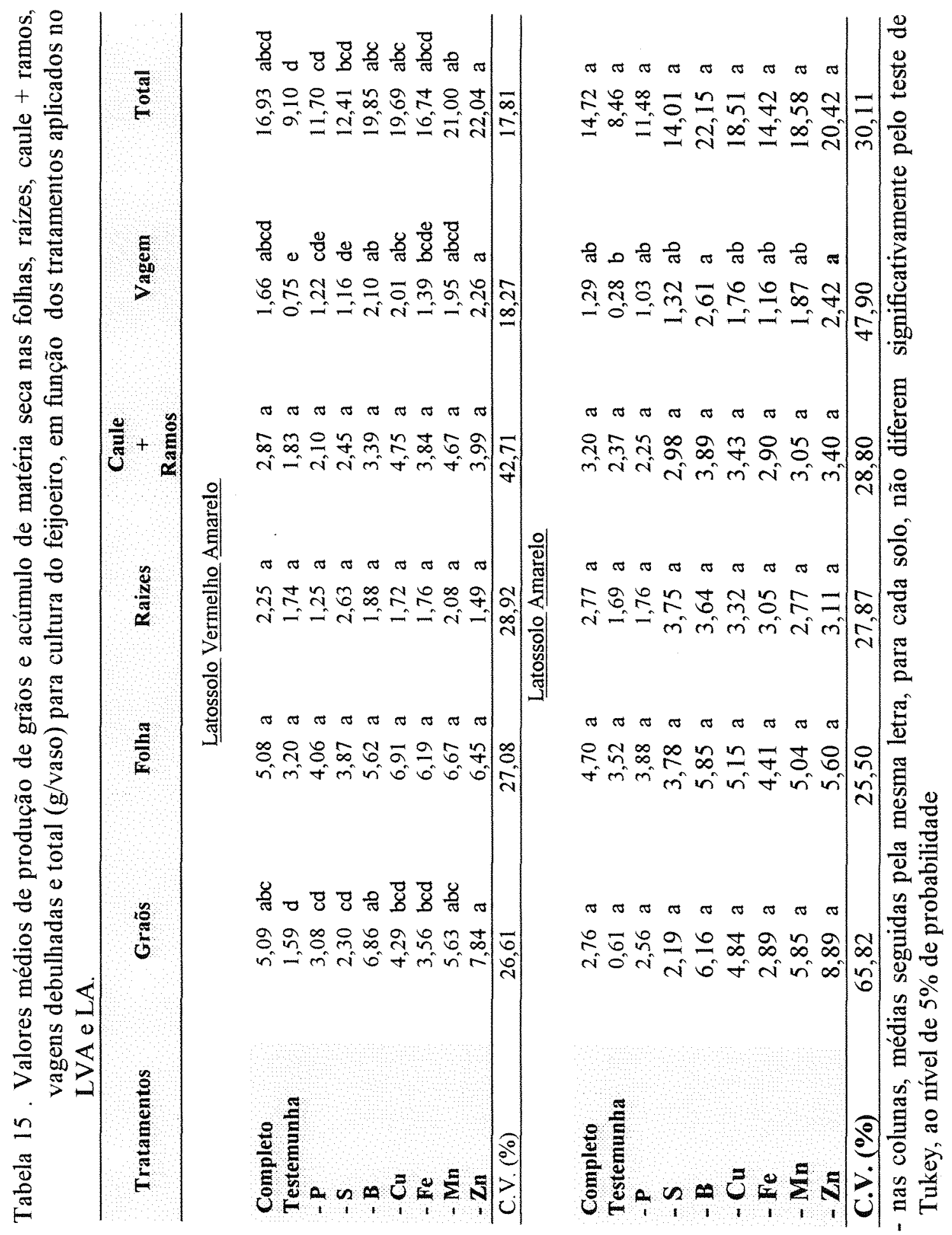




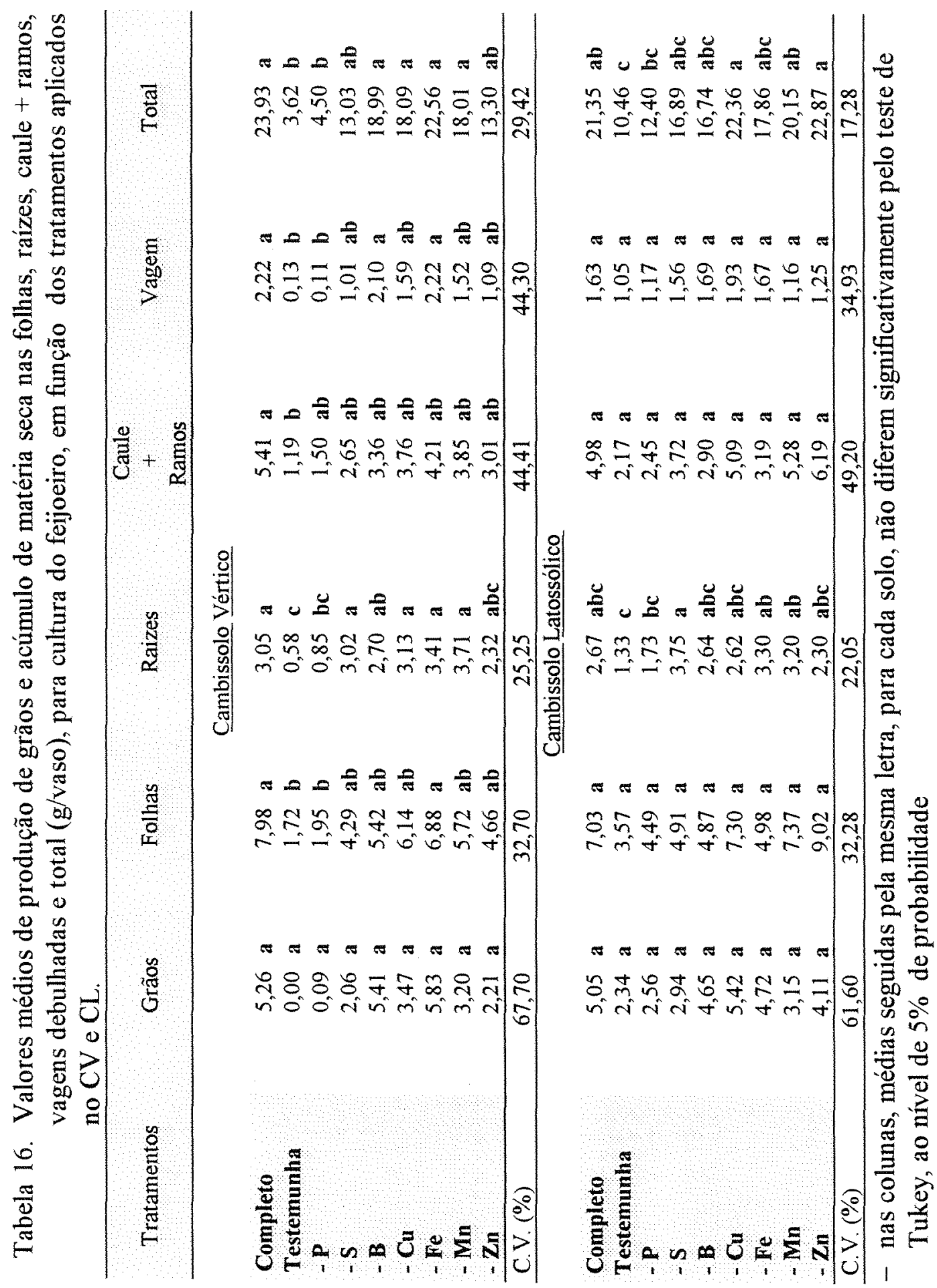


Tabela 17. Produção relativa de grãos em função dos tratamentos aplicados no LVA, LA, CV e CL

\begin{tabular}{|c|c|c|c|c|}
\hline \multirow[t]{2}{*}{ Tratamento } & \multicolumn{4}{|c|}{ Grāos (Prod relativa) } \\
\hline & LVA & LA & $\mathrm{CV}$ & $\mathrm{CL}$ \\
\hline Completo & 100 & 100 & 100 & 100 \\
\hline Testemunha & 31 & 22 & 0 & 46 \\
\hline$-\mathrm{P}$ & 60 & 93 & 2 & 51 \\
\hline$-S$ & 45 & 79 & 39 & 58 \\
\hline$-B$ & 135 & 223 & 103 & 92 \\
\hline$-\mathrm{Cu}$ & 84 & 175 & 66 & 107 \\
\hline$-\mathrm{Fe}$ & 70 & 105 & 111 & 94 \\
\hline$-\mathrm{Mn}$ & 111 & 212 & 61 & 62 \\
\hline$-\mathrm{Zn}$ & 154 & 213 & 42 & 81 \\
\hline
\end{tabular}

\subsubsection{Teor e Conteúdo de Fósforo}

Nas tabelas $18,19,20,21,22$ e 23 são apresentados, respectivamente os teores de fósforo nas folhas e nos grãos do feijoeiro, como também as quantidades de fósforo exportadas nos grãos pela cultura.Observa-se nas tabelas 18 e 19 para os quatro solos estudados, que o teor de fósforo nas folhas do feijoeiro, em função dos tratamentos aplicados apresentaram diferenças estatísticas pelo teste de Tukey, ao nivel de $5 \%$ de probabilidade. Nas tabelas 18 e 19 , visualiza-se que os maiores teores de fósforo nas folhas encontram-se: para o LVA, nos tratamentos com omissão de cobre e manganês; para o LA, no tratamento menos boro e para o $\mathrm{CV}$ e $\mathrm{CL}$ no tratamento menos zinco. Vale ressaltar, que as médias dos teores mais altos de fósforo nas folhas, não diferem significativamente das médias dos teores de fósforo no tratamento completo. Todavia, diferem sifgnificativamente das médias dos menores teores de fósforo do tratamento menos fósforo no LVA, CV e CL e do tratamento testemunha no LA.

Os maiores teores de fósforo nas folhas do feijoeiro, no tratamento menos zinco, no CV e CL, vem de encontro aos resultados do ensaio de AMBLER \& 
BROWN (1969), que constataram haver mais acúmulo de fósforo em plantas de feijäo submetidas à deficiência de zinco.

Nos grãos (tabelas 20 e 21), o menor teor de fósforo ocorreu para o LVA e LA no tratamento testemunha, para o CV nos tratamentos testemunha e menos fósforo e para o CL no tratamento menos manganês. Em ambos os solos, a omissão de enxofre apresentou o maior teor de fósforo, provavelmente, isto tenha acontecido em função do efeito de concentração, dado a pequena produção de grãos deste tratamento, resultados semelhantes foram encontrados por EL-HUSNY (1992). Nas tabelas 22 e 23 , os menores conteúdos de fósforo correspondem ao tratamento testemunha para o LVA, LA e CL e no testemunha e menos fósforo para o $\mathrm{CV}$. Com os maiores conteúdos na omissão de zinco e ferro para o LVA e CV respectivamente e diferindo estatisticamente do completo, e na omissão de boro e no tratamento completo para o LA e CL respectivamente, sem apresentarem diferenças significativas do tratamento completo.

É importante observar, que os menores teores e conteúdos de fósforo tanto nas folhas como nos grãos, é proporcionado pelos tratamentos testemunha e pela omissão de fósforo, mesmo com o alto teor do nutriente no solo LVA, LA e CL (tabela 30).

Os teores de fósforo apresentados nas folhas e nos grãos do feijoeiro, de uma forma geral, estão de acordo com outros resultados (HAAG et al., 1967; COBRA NETO et al., 1971 e EL-HUSIN, 1992), quanto a distribuição de fósforo entre as folhas e os grãos os maiores teores encontam-se nos grãos, resultado idêntico foi obtido por COBRA NETO (1971) e EL-HUSIN (1992).

Em função dos baixos teores e conteúdos de fósforo nas folhas e nos grãos, quando se omitiu este elemento, como também, pelo efeito depressivo deste tratamento sobre a produção de grãos do feijoeiro, pode-se deduzir nas condições deste ensaio, que ambos os solos respondem a adubação fosfatada.

\subsubsection{Teores e Conteúdo de $\mathrm{K}, \mathrm{Ca}$ e $\mathrm{Mg}$}

Nas tabelas 18 e 19, observa-se que os teores de potássio nos quatro solos e os teores de cálcio e magnésio no LA e CL, diferem significativamente entre alguns tratamentos pelo teste de Tukey, ao nivel de $5 \%$ de probabilidade. Todavia, os teores de cálcio e magnésio no LVA e CV não diferem estatisticamente. 
No LVA os tratamentos que apresentaram o maior e menor teor de potássio nas folhas foram a testemunha e o menos ferro respectivamente. Os demais tratamentos somente com omissão de fósforo e cobre apresentaram diferenças estatísticas em relação ao completo. Observa-se nos teores de K, Ca e Mg no LA e K no $\mathrm{CV}$, que a omissão do fósforo favoreceu a absorção em ordem decrescente do potássio, cálcio e magnésio e somente o teor de potássio apresentou diferença estatística em relação ao completo. Os dados obtidos neste ensaio no que se refere a absorção de potássio, mostram-se concordantes com os observados por COBRA NETO (1967). Percebe-se, também, no $C L$, que a omissão de cobre favoreceu também a absorção de potássio, cálcio e magnésio em ordem decrescente e da mesma forma somente a absorção de $\mathrm{K}$ difere do tratamento completo. Este fato pode ser justificado com o aumento da produção relativa do $\mathrm{CL}$ na omissão de cobre.

Pelas tabelas 20 e 22, observa-se que tanto os teores de $\mathrm{K}$ no LVA e LA, como seu conteúdo no LVA diferem significativamente entre o tratamento completo e testemunha. É importante também, verificar na tabela 21 , que os tratamentos testemunha e menos fósforo no $\mathrm{CV}$ não atingiram produção de grãos, razão pela qual os teores de potássio, cálcio e magnésio são nulos.

Os teores de potássio, cálcio e magnésio encontrados nas folhas e nos grãos do feijoeiro, assemelham-se aos obtidos por HAAG et al. (1967), COBRA NETO et al. (1971) e EL-HUSIN (1992).

Nas tabelas 22 e 23 verifica-se, pelos conteúdos de potássio, cálcio e magnésio, que o potássio é o nutriente mais exportado seguido do cálcio e magnésio. Estes resultados são semelhantes aos obtidos no ensaio do estudo da relação $\mathrm{K} /(\mathrm{Ca}+\mathrm{Mg})$ e são confirmados pelos trabalhos dos autores acima citados.

\subsubsection{Teores e Conteúdos do Enxofre}

Observando as tabelas 18, 19, 20 e 21, percebe-se claramente ao comparar os teores de enxofre nas folhas e nos grãos de todos os tratamentos, que estes valores estão muito abaixo dos encontrados por MALAVOLTA et al. (1989), HAAG (1967), COBRA NETO (1971) e EI-HUSIN (1992). Os teores encontrados nos grãos e nas folhas neste ensaio, são cinco a dez vezes menores respectivamente, que os considerados adequados pelos autores para cultura do feijoeiro. Em função dos baixos teores de enxofre encontrados nas folhas e nos grãos do feijoeiro, como 
também, pela redução na produção relativa de grãos (tabela 17), quando da omissão de enxofre, pode-se inferir que nas condições deste ensaio, todos os solos respondem a adubação com enxofre.

Os teores de enxofre em ambos os solos como foi discutido no ítem 4.1.3 Análises Químicas, são considerados altos e acima do nivel crítico encontrado na literatura, independentemente dos $30 \mathrm{mg} / \mathrm{dm}^{3}$ de $S$ adicionados na adubação de plantio.

Em solos áridos ou semi-áridos como a microrregião de Irecê-BA, o $\mathrm{SO}_{4}{ }^{2-}$ precipita em grandes quantidades como sulfatos de $\mathrm{Na}, \mathrm{K}, \mathrm{Ca}, \mathrm{Mg}$. Para BOLAN et al (1993) nos solos calcários $\circ \mathrm{Ca}^{2+}$ é atraido eletrostaticamente à superfície de argilo-minerais gerando cargas positivas. $\mathrm{O} \mathrm{SO}_{4}^{-}$por sua vez também é atraído para sítios positivos onde fica adsorvido, diminuindo consequentemente sua disponibilidade nos solos. 


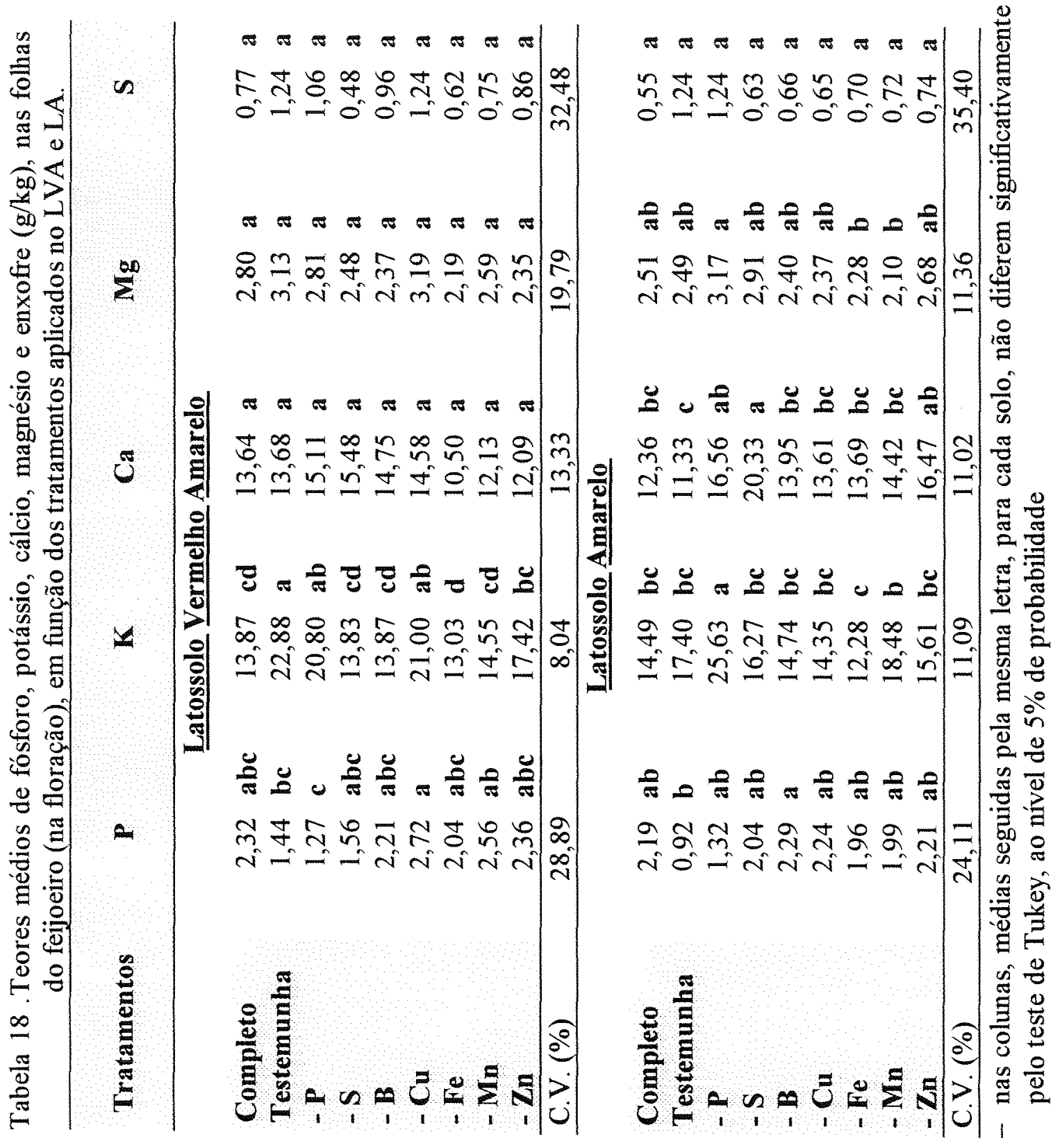




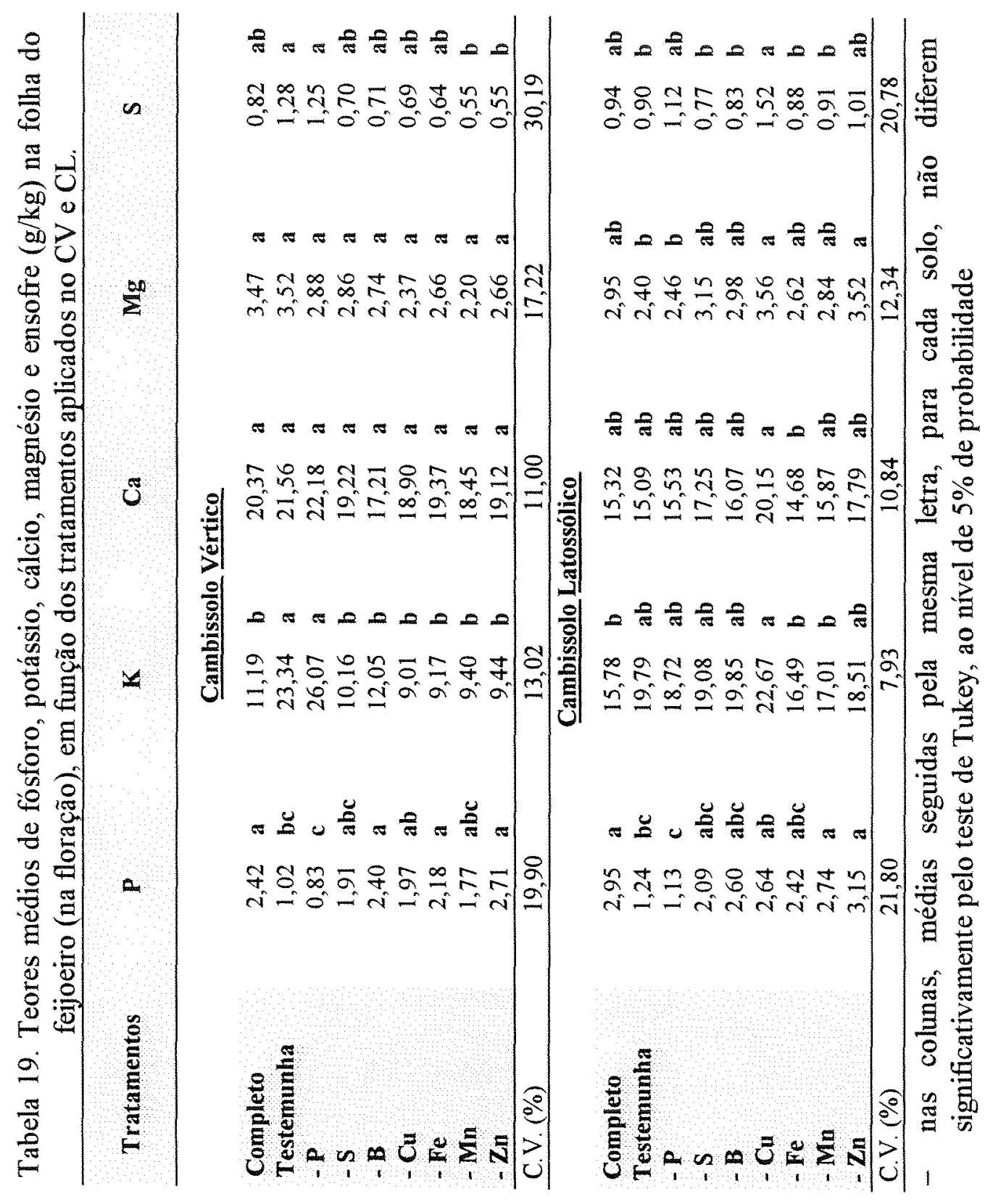




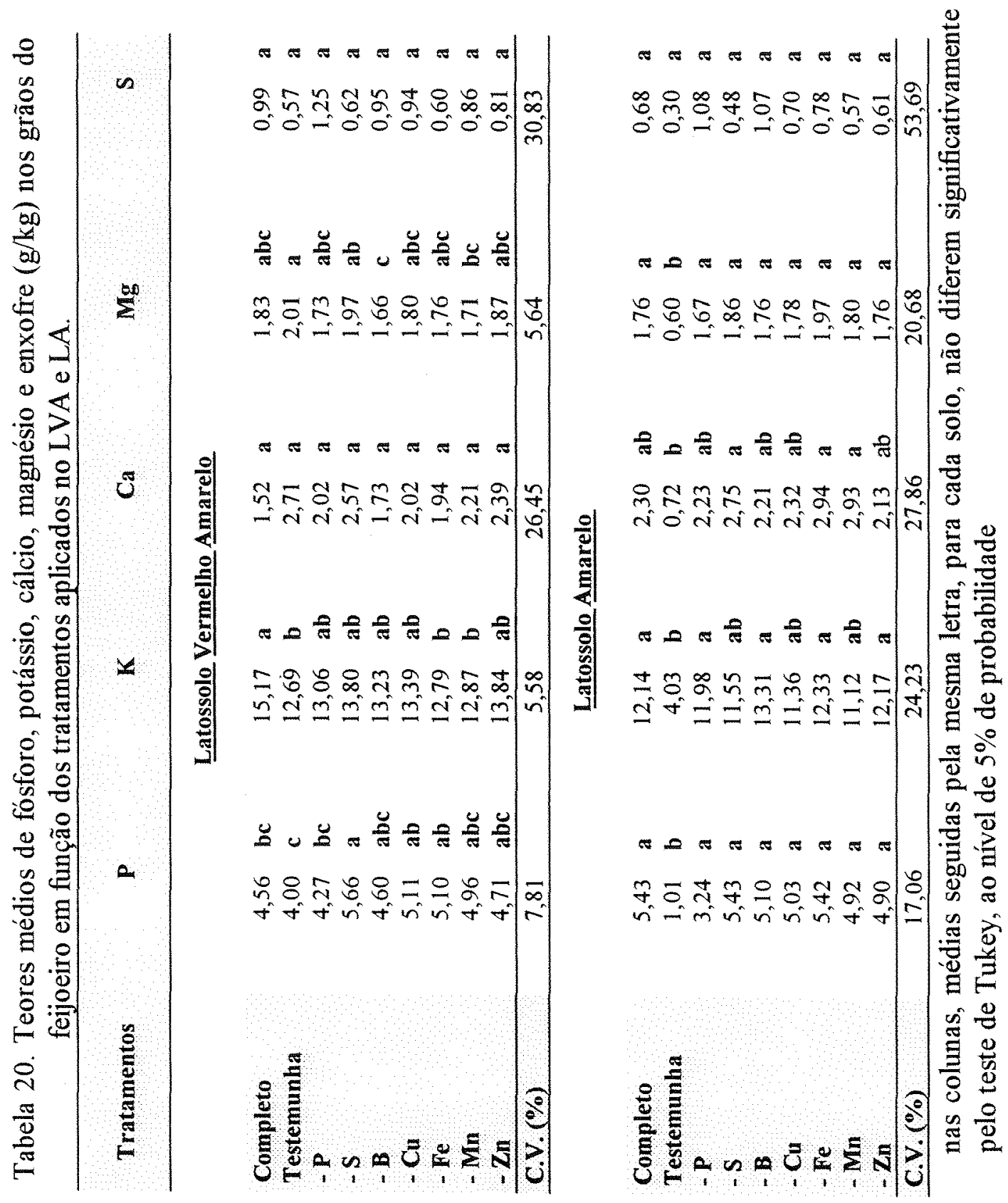




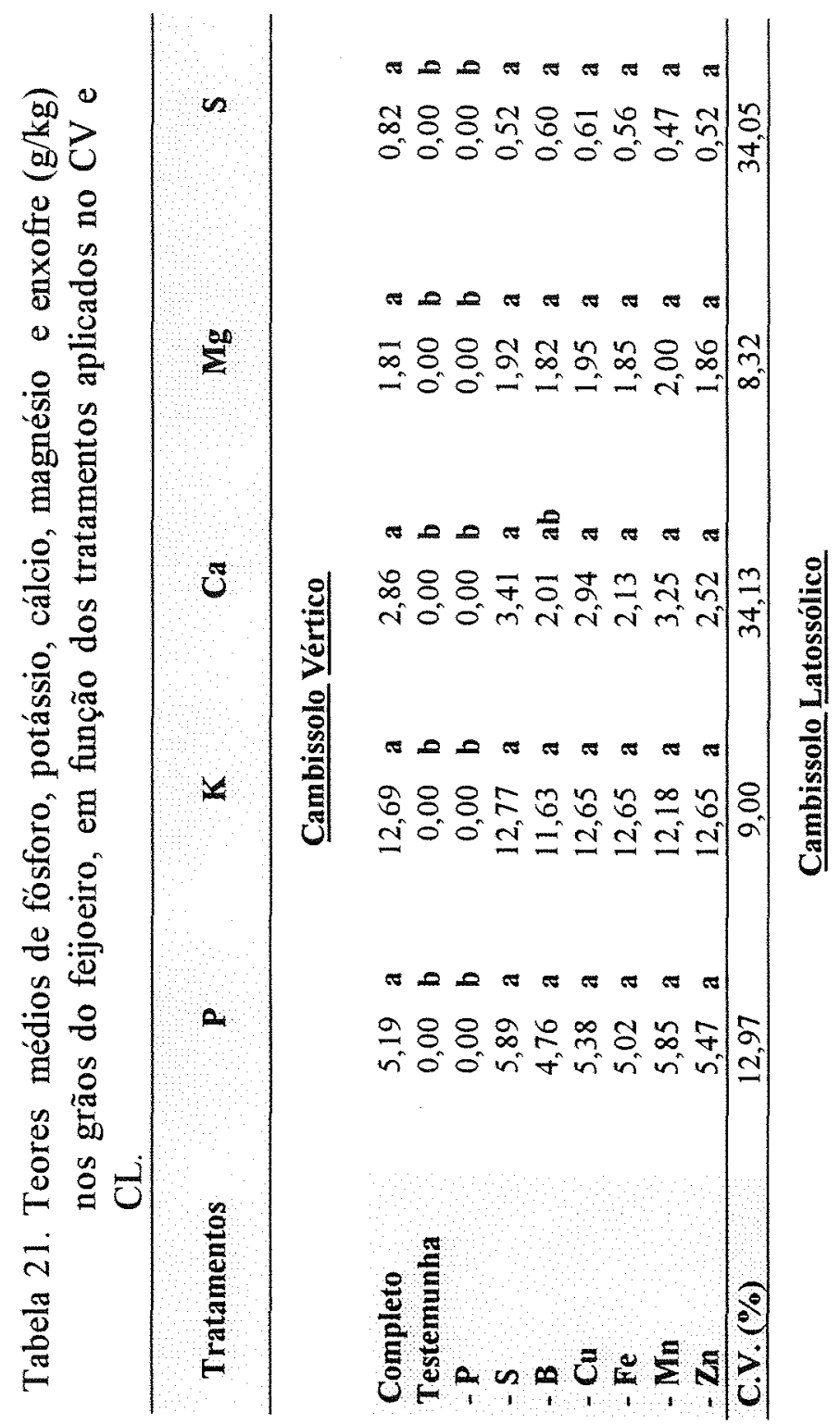

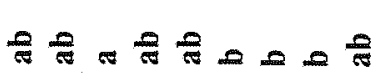

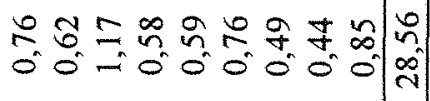

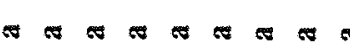

동

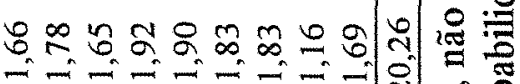

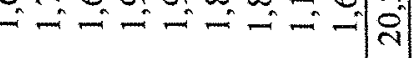

응 은

* * *

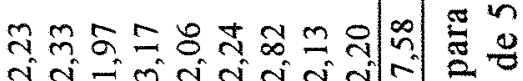

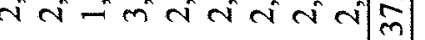

$4 \pi 4 \pi \pi 4 \pi$

苾总

○०m+o +

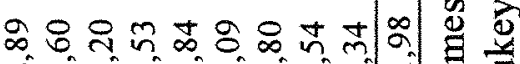

तरत्रती $=\infty$ लीज

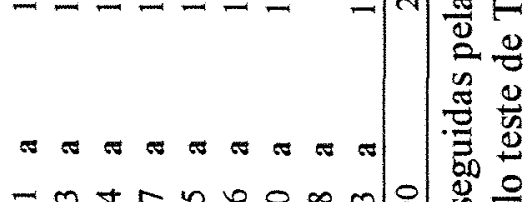

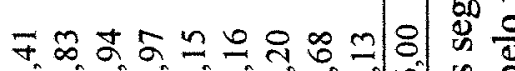

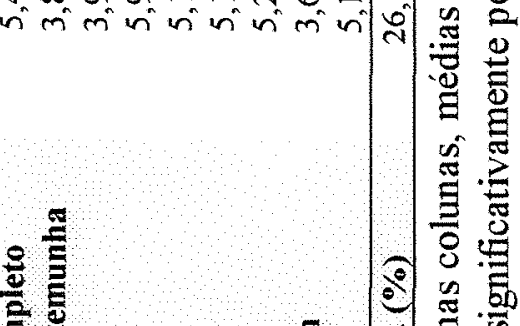

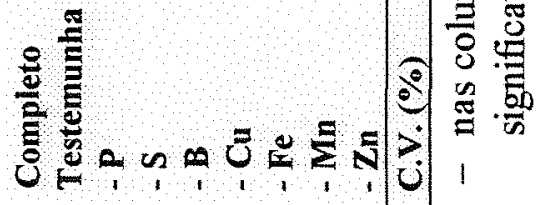




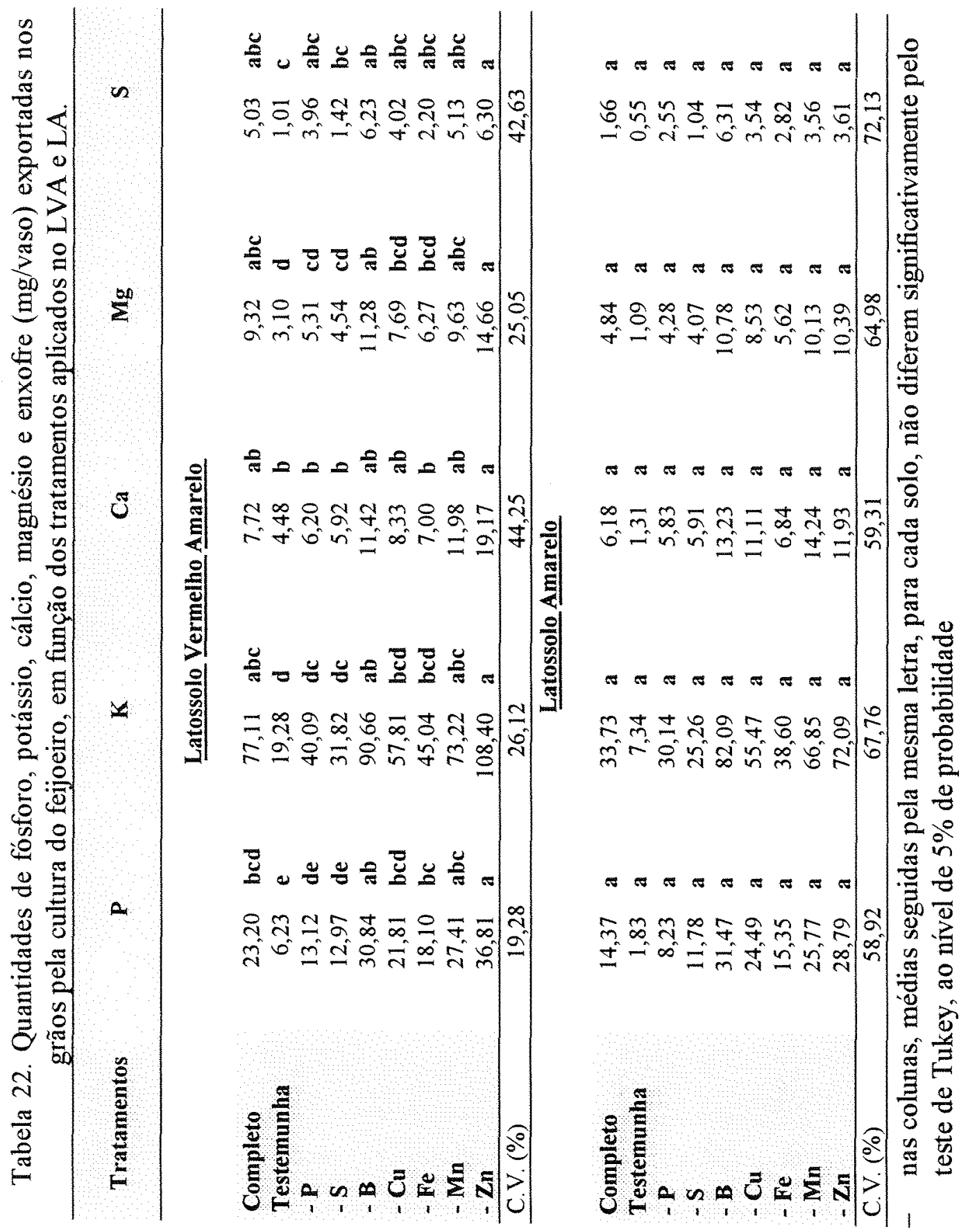




\subsubsection{Teor e Conteúdo de Boro}

Nas tabelas $24,25,26,27,28$ e 29 são apresentados, respectivamente os teores de boro nas folhas e nos grãos do feijoeiro, como também as quantidades de boro exportadas nos grãos pela cultura.

Nas tabelas 24 e 25 encontram-se os teores de boro nas folhas do feijoeiro, onde nota-se, que no solo LVA e CL os teores não diferem estatisticamente, ocorrendo pequenas diferenças significativas no solo $\mathrm{LA} \mathrm{e} \mathrm{CV}$. Os tratamentos com omissão de fósforo e enxofre no LA, e o tratamento testemunha no $\mathrm{CV}$ apresentaram os maiores teores de boro nas folhas, não diferindo estatisticamente do completo, enquanto que os tratamentos com omissão de boro, ferro e manganês, para o solo LA e o de omissão de zinco no CV apresentaram os menores teores e, diferem significativamente dos tratamentos que apresentaram maiores teores.

Percebe-se nas tabelas 26 e 27 , que os teores de boro nos grãos não apresentaram diferenças significativas, e que os teores nulos nos tratamentos testemunha e menos fósforo no $\mathrm{CV}$, é pelo fato de não ter ocorrido produção de grãos nestes tratamentos. As tabelas 28 e 29 mostram que a maior exportação de boro pelos grãos ocorreu: no LVA pelos tratamentos completo, menos boro, menos manganês e menos zinco; no LA pelos tratamentos menos boro, menos manganês e menos zinco; no CV pelos tratamentos completo, menos boro, menos ferro; no $\mathrm{CL}$ pelos tratamentos completo, menos boro, menos cobre e menos ferro, exatamente onde foram registradas as maiores produções de grãos.

Os teores de boro apresentados neste estudo, estão de acordo com MALAVOLTA (1989) e EL-HUSNY (1992).

\subsubsection{Teor e Conteúdo de Cobre}

Nas tabelas $24,25,26,27,28$ e 29 encontram-se os teores de cobre nas folhas e nos grãos do feijoeiro, como também as quantidades exportadas pelos grãos. Os tratamentos com omissão de fósforo e enxofre no LVA, omissão de enxofre no $L A$ e $C L$ e omissão de fósforo no $C V$, aumentaram os teores e as quantidades de cobre nas folhas e nos grãos do feijoeiro. Estes resultados encontram apoio nos trabalhos de MALAVOLTA (1980), e discorda dos resultados apresentados por EL-HUSNY (1992), onde a omissão de fósforo e enxofre segundo o autor condicionaram decréscimos no acúmulo de cobre nas folhas e nos grãos do feijoeiro. 
Os teores de cobre encontrados nas folhas, assemelham-se aos teores encontrados por EL-HUSNY (1992).

\subsubsection{Teor e Conteúdo de Ferro}

Pelas tabelas 24 e 25 , verifica-se que os teores de ferro nas folhas do feijoeiro no solo LVA e no CV não diferem significativamente pelo teste de Tukey, ao nivel de $5 \%$ de probabilidade. Todavia, nos solos $\mathrm{LA}$ e $\mathrm{CL}$ os teores apresentam algumas diferenças estatísticas. Os tratamentos com omissão de enxofre e zinco no LA e o tratamento com omissão de fósforo no $\mathrm{CL}$ apresentaram os maiores teores de ferro nas folhas do feijoeiro. Estes resultados, concordam com os obtidos por MALAVOLTA (1980).

No LVA tabela 26 , os teores de ferro nos grãos não apresentam diferenças significativas. Para a quantidade de ferro acumulada nos grãos, tabela 28 , o maior destaque correspondeu a testemunha que proporcionou uma redução, porém a omissão de zinco registrou o maior acúmulo de ferro. No LA tabela 26, a testemunha apresentou o menor teor de ferro, e também apresentou na tabela 28 , a menor quantidade acumulada nos grãos. No CV e CL tabelas 27 e 29 , tanto os teores quanto as quantidades de ferro nos grãos não apresentaram diferenças significativas.

A omissão de zinco aumentando a quantidade de ferro acumulada nos grãos, também foi encontrada por EL-HUSNY (1992).

os teores de ferro observados neste ensaio, encontram-se dentro da faixa considerada adequada por MALAVOLTA et al. (1989). Segundo o autor por ser um elemento parcialmente móvel na planta, as maiores quantidades encontram-se nas folhas, como pode ser observado neste trabalho.

\subsubsection{Teor e Conteúdo de Manganês}

Visualizando as tabelas 24 e 26 , percebe-se que, a omissão de enxofre no solo LA aumentou o teor de manganês nas folhas e nos grãos do feijoeiro, enquanto que o tratamento testemunha e a omissão de fósforo reduziram estes teores. Na tabela 25 no $\mathrm{CV}$, o tratamento testemunha aumenta o teor de manganês nas folhas, enquanto que o tratamento com omissão de cobre reduz este teor, no $\mathrm{CL}$ ocorre o contrário, a omissão de cobre aumenta o valor e o tratamento testemunha reduz. 
Provavelmente o maior teor de manganês nas folhas e nos grãos com a omissão do enxofre, tenha acontecido, em razão do efeito de concentração, pois este tratamento proporcionou um pequeno desenvolvimento da planta, cuminando com uma baixa produção. Pode-se observar nas tabelas 28 e 29 que o mesmo não ocorreu para as quantidades de manganês nos grãos.

Na tabela 28 a omissão de zinco no LVA e a omissão do boro no LA aumentam a quantidade de manganês exportadas pelos grãos, o que está de acordo com o que é citado pela literatura.

Os teores de manganês encontrados neste ensaio, situam-se na faixa adequada sugerida por MALAVOLTA et al. (1989). Quanto a distribuição do manganês na planta, as folhas apresentam maiores quantidades que nos grãos, como citado por MALAVOLTA (1980).

\subsubsection{Teor e Conteúdo de Zinco}

Nas tabelas 24 e 25, pode-se observar para o solo LVA, LA e CV que a omissão de fósforo aumentou o teor de zinco nas folhas do feijoeiro.

Para os teores de zinco nos grãos (tabelas 26 e 27) e para a quantidade de zinco exportada pelos mesmos (tabelas 28 e 29), as médias não diferem significativamente pelo teste de Tukey, ao nivel de $5 \%$ de probabilidade, exceto para o solo LVA na tabela 28 , onde chama atenção os tratamentos testemunha e menos enxofre, pela menor quantidade de zinco acumulada.

A explicação para a omissão de fósforo favorecer à absorção de zinco segundo MANDAL \& HALDAR (1980) é que a aplicação de fósforo causa efeito depressivo no conteúdo de zinco disponível no solo, sendo este efeito mais proeminente no zinco nativo do solo do que o aplicado. Todavia OLSEN (1972) procurando explicação para o fato, verificou que o fósforo precipitando o zinco no solo não é uma explicação satisfatória. Um efeito do fósforo atuando no sítio de absorção ou limitando a translocação ou mesmo a utilização do zinco pelas plantas parece uma hipótese mais satisfatória. Quanto a relação entre enxofre e zinco observada neste estudo, os efeitos foram semelhantes aos observados por El-HUSNY (1992). Os teores de zinco nas folhas e nos grãos, constatado neste ensaio, encontram-se na faixa adequada relatada por MALAVOLTA (1989). 


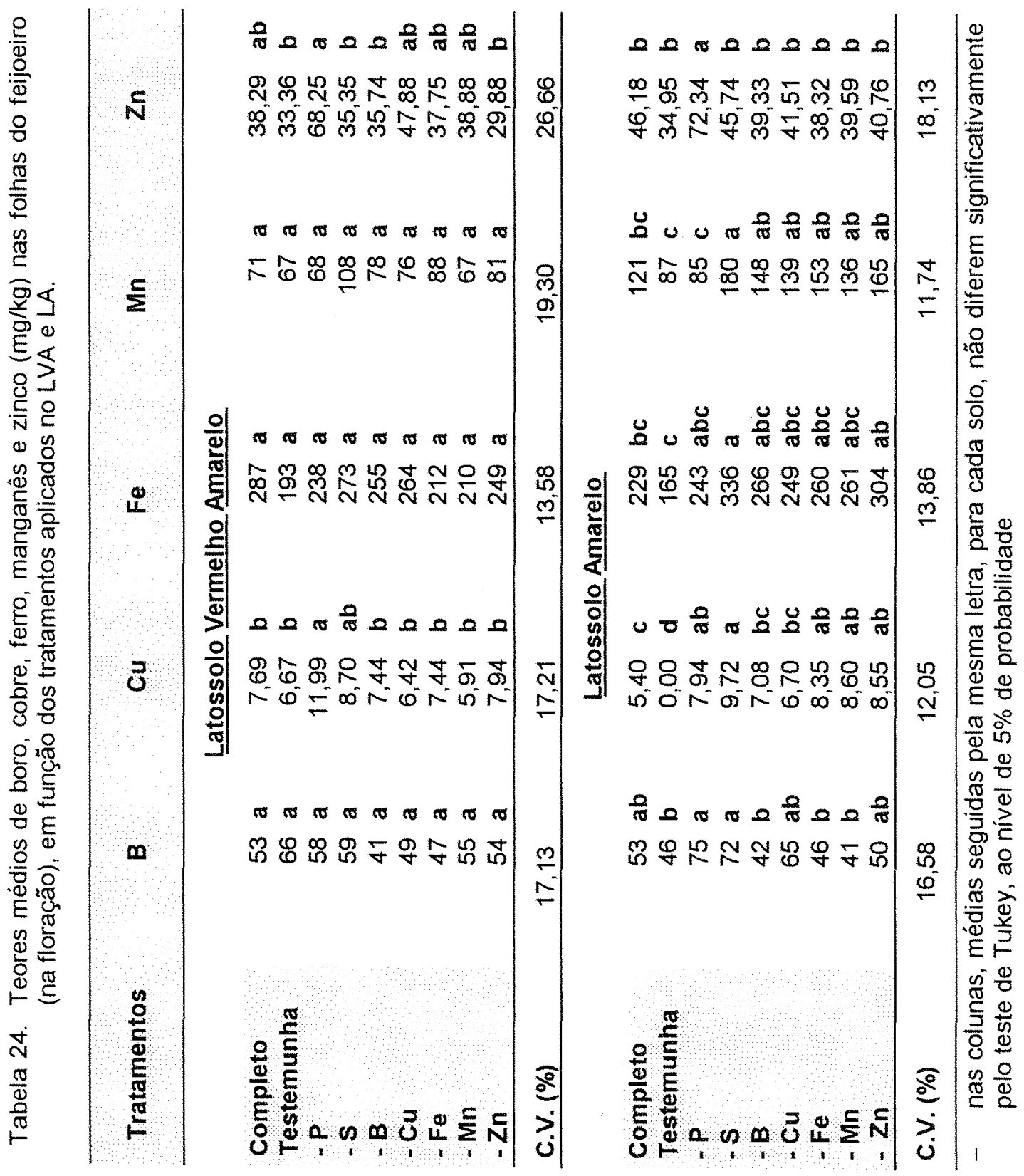




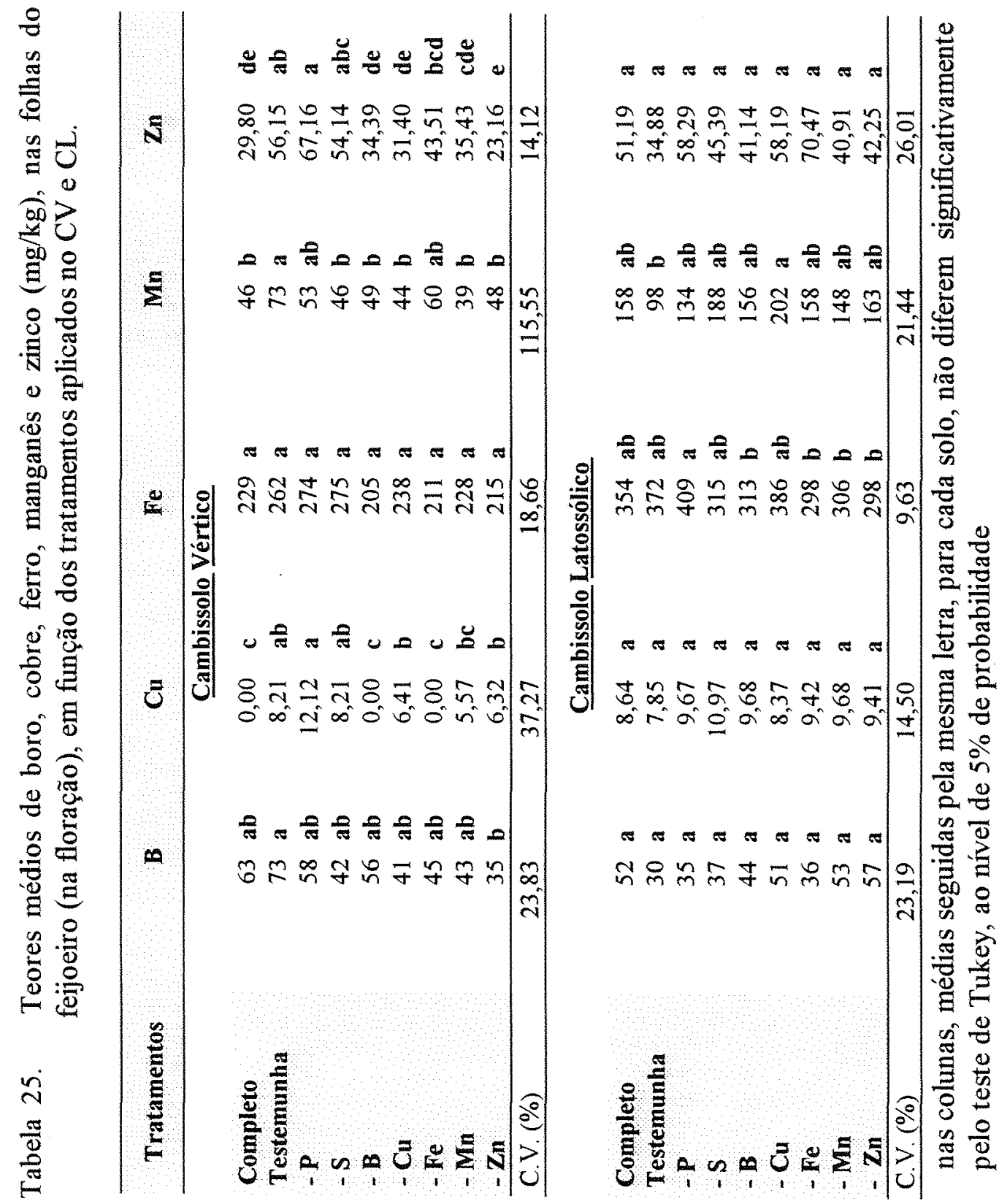




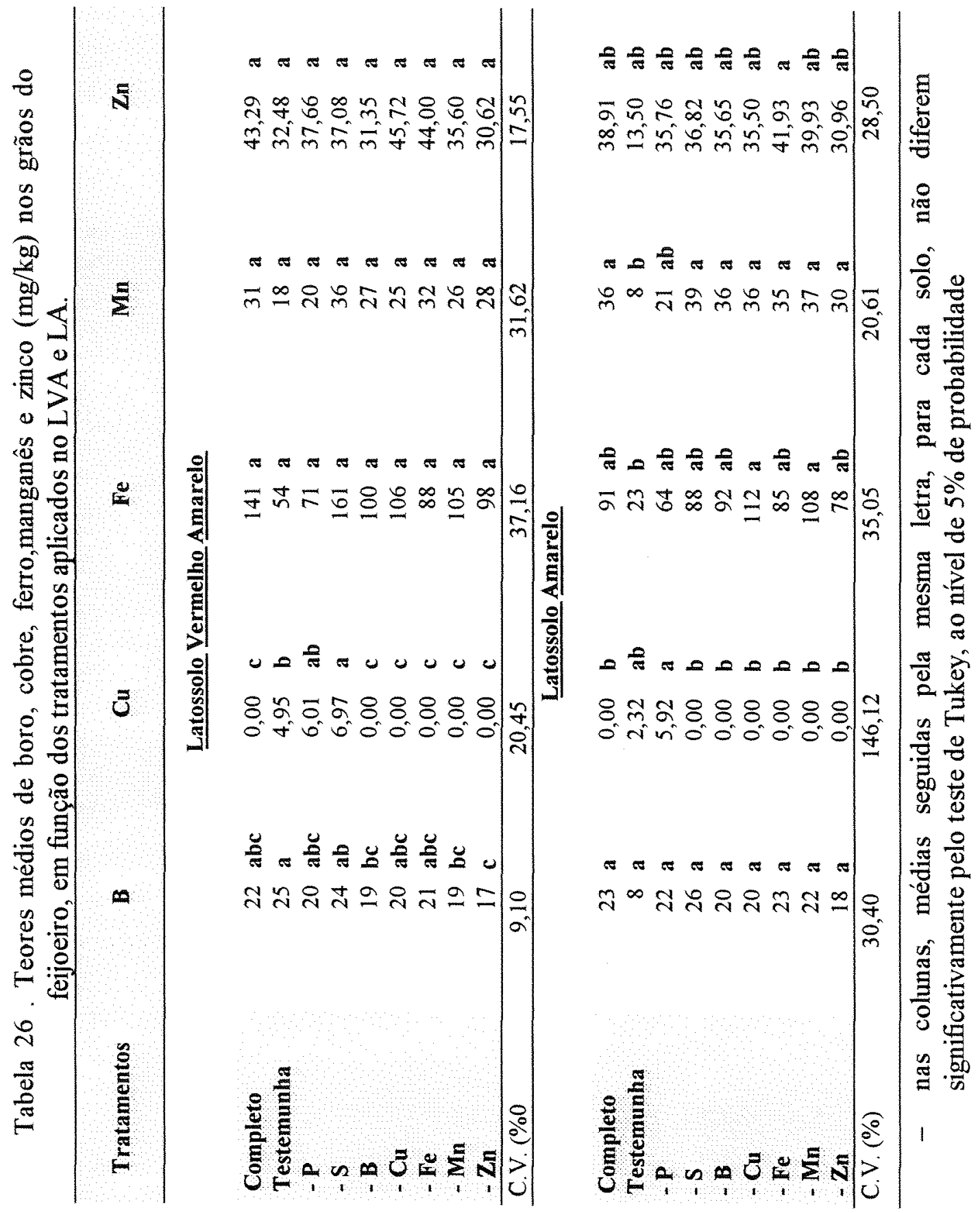



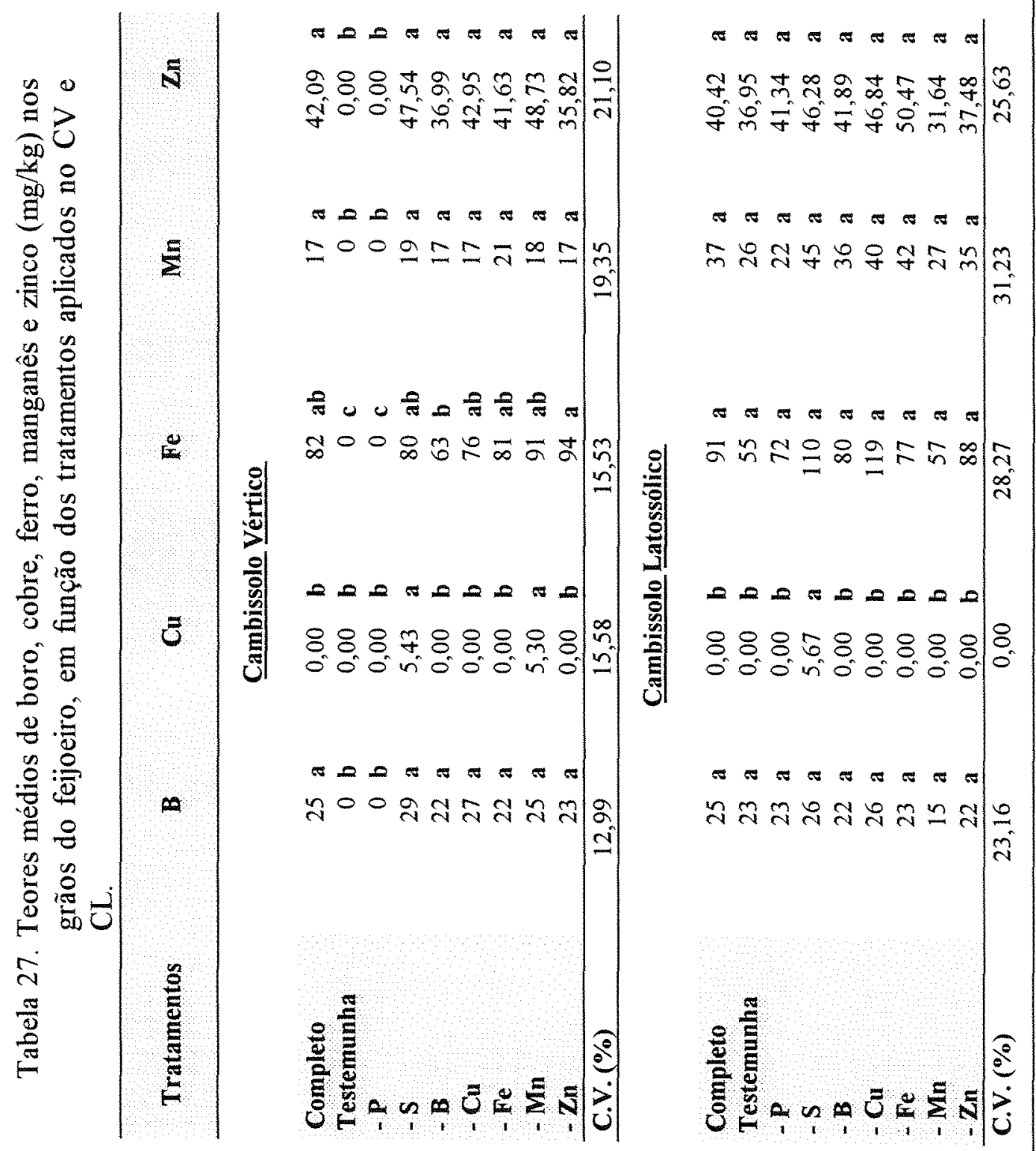

造

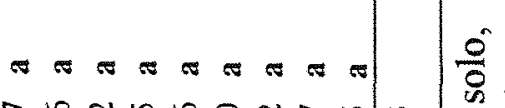

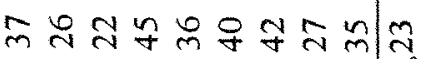

รึ

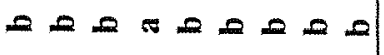

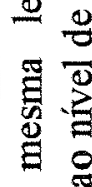

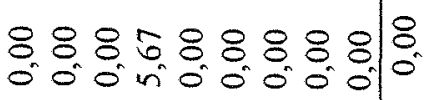

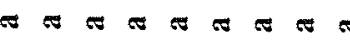

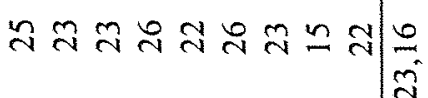

क

荡

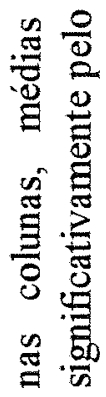




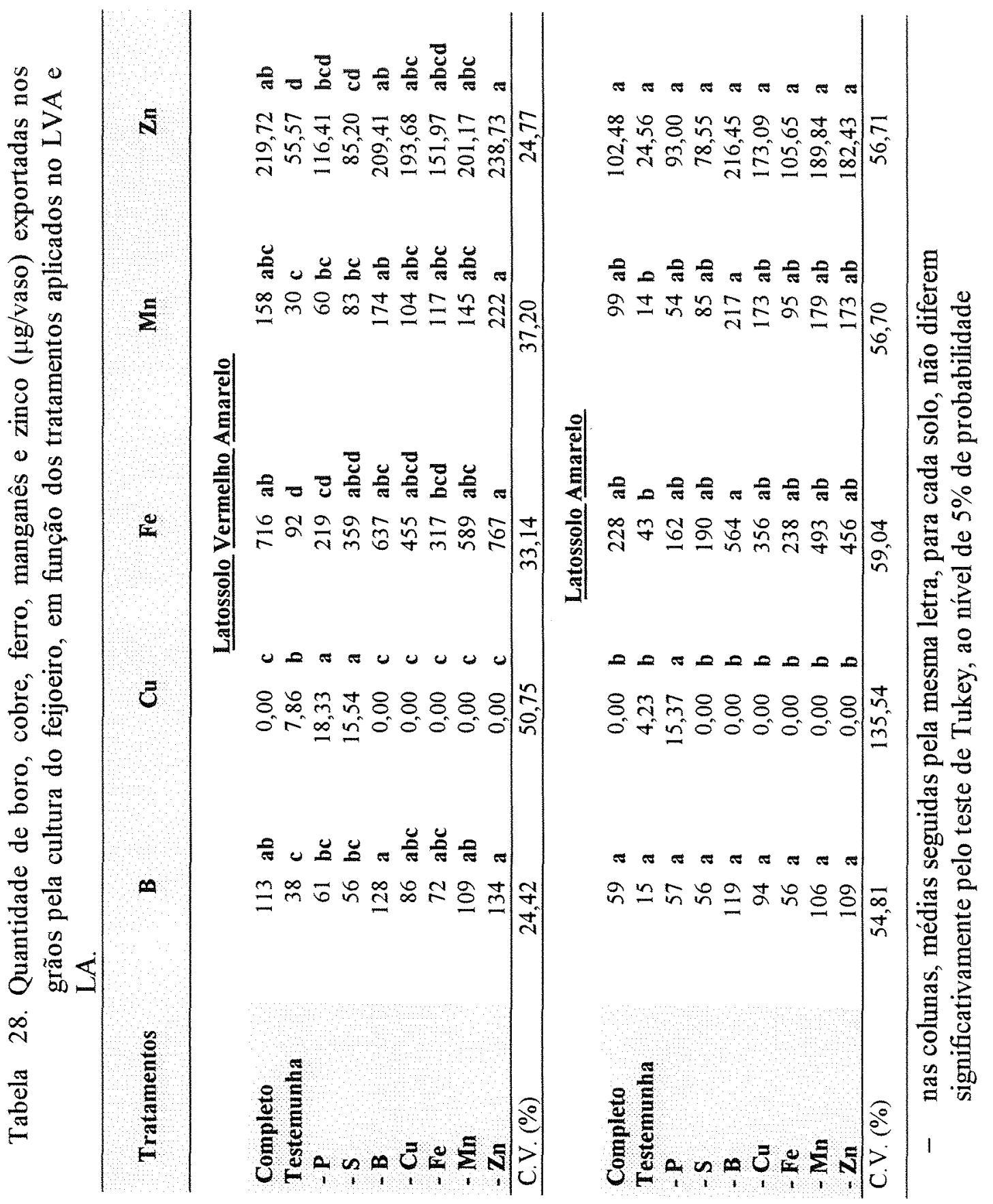




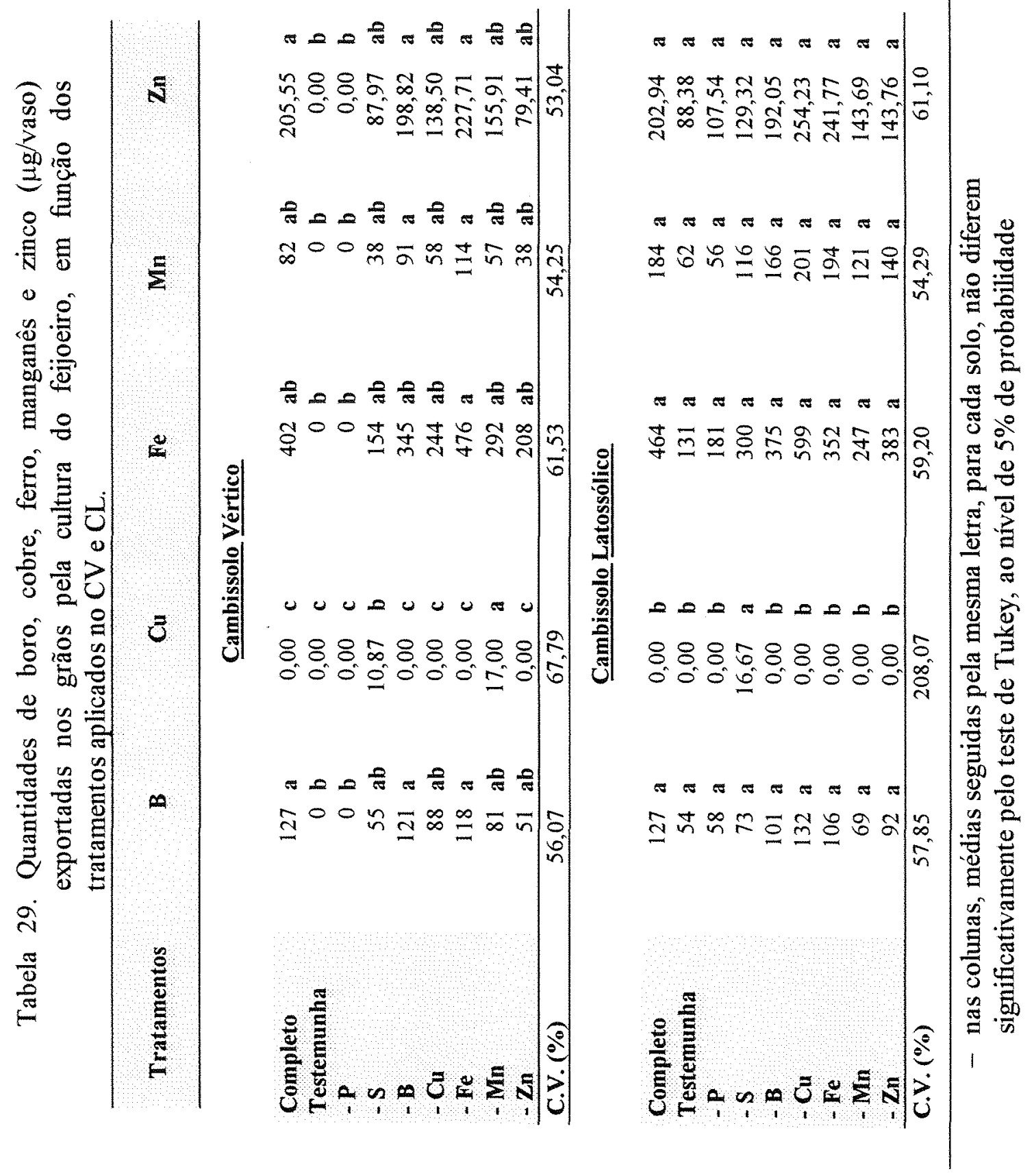




\subsubsection{Valores de Macro e Micronutrientes Recuperados Antes e Após o Cultivo dos Solos em Função dos Tratamentos Aplicados}

Pela tabela 30 , visualiza-se os valores médios de fósforo disponiveis e potássio, cálcio e magnésio trocáveis, recuperados após o periodo de incubação e antes do plantio, com as médias não diferindo significativamente pelo teste de Tukey, ao nivel de $5 \%$ de probabilidade.

Foram feitas correlações entre os valores de fósforo extraidos com os extratores resina e Olsem verso produção de matéria seca de grãos, e para ambos os solos, as correlações não foram significativas.

Na tabela 31, encontram-se os valores médios de fósforo disponíveis, enxofre, boro, cobre, ferro, manganês, zinco e potássio, cálcio e magnésio trocáveis antes do cultivo. Foram analisadas apenas uma amostra de cada solo com três repetiçòes. As análises de fósforo, potássio, cálcio e magnésio do $\mathrm{CV}$, não foram realizadas em todos os tratamentos como no LVA, LA e CV (tabela 30), porque não foi incubado com nenhum tratamento, como descrito no material e métodos.

Os valores encontrados nas tabelas 30 e 31, de uma certa forma, foram discutidos no item 4.3.1 Análises Químicas do capitulo 4.1 características Físicas, Mineralógicas e Químicas dos Solos. Como também, citado durante a discussão dos dados.

Verifica-se nas tabelas 32 e 33 os valores médios de fósforo e enxofre disponíveis, potássio, cálcio e magnésio trocáveis após o cultivo dos solos. Observase, que os valores de fósforo para ambos os solos, nos tratametnos testemunha e com omissão de fósforo, diferem significativamente pelo teste de Tukey, ao nível de $5 \%$ de probabilidade, dos demais tratamentos. Esta diferença é em função de que estes dois tratamentos foram os únicos que não receberam fósforo na adubação de plantio. Também, foram feitas correlações entre os valores de fósforo disponiveis após o cultivo extraídos com os extratores resina e Olsem verso Produção de matéria seca de grãos. No LVA a correlação com fósforo resina foi significativa a $5 \%$ com $r=0,3913$, com fósforo Olsem também significativa a $5 \%$ com $r=0,4116$. No CV a correlação com fósforo resina foi significativa a $5 \%$ com $r=0,4395$, com o fósforo 
Olsem significativa a $1 \%$ com $r=0,5116$. Nos solos $L A$ e $C L$ as correlações com a produção de grãos não foram significativas.

Os valores de enxofre recuperados após o cultivo no LVA e LA não diferem significativamente entre os tratamentos, tendo-se observado diferenças entre os mesmos no $\mathrm{CV}$ e CL. É importante chamar atenção que o coeficiente de variação para a análise de enxofre foi muito alto.

Os valores de potássio, cálcio e magnésio de uma forma geral não apresentaram diferenças significativas importantes.

Observa-se pelas tabelas 34 e 35 que para todos os micronutrientes, somente no zinco os tratamentos testemunha e com omissão de zinco, diferem significativamente pelo teste de Tukey, ao nivel de $5 \%$ de probabilidade, dos demais tratamentos. 
Tabela 30. Valores médios de fósforo disponíveis $\left(\mathrm{mg} / \mathrm{dm}^{3}\right)$, potássio, cálcio e magnésio trocáveis $\left(\mathrm{mmol}_{\mathrm{c}} / \mathrm{dm}^{3}\right)$, recuperados antes do cultivo dos solos, em função dos tratamentos aplicados no LVA, LA e CL.

\section{Tratamentos}

P

$\mathbf{P}$

K

Ca

Mg

Resina

Olsem

Latossolo Vermelho Amarelo

\begin{tabular}{|c|c|c|c|c|c|c|c|c|c|c|}
\hline Completo & 59 & $\mathbf{a}$ & 33 & $\mathbf{a}$ & 24,80 & $\mathbf{a}$ & 260,00 & $\mathbf{a b}$ & 26,44 & a \\
\hline Testemunha & 60 & $\mathbf{a}$ & 32 & $\mathbf{a}$ & 14,85 & b & 218,33 & b & 26,17 & $\mathbf{a}$ \\
\hline -P & 60 & $\mathbf{a}$ & 31 & $\mathbf{a}$ & 23,94 & $\mathbf{a}$ & 223,33 & $\mathbf{b}$ & 26,44 & $\mathbf{a}$ \\
\hline$-S$ & 59 & $\mathbf{a}$ & 32 & $\mathbf{a}$ & 25,29 & $\mathbf{a}$ & 275,67 & $\mathbf{a}$ & 24,22 & $\mathbf{a}$ \\
\hline$-B$ & 56 & $\mathbf{a}$ & 34 & $\mathbf{a}$ & 23,33 & $\mathbf{a}$ & 249,67 & $a b$ & 25,61 & $\mathbf{a}$ \\
\hline$-\mathrm{Cu}$ & 56 & $\mathbf{a}$ & 34 & $\mathbf{a}$ & 24,31 & a & 254,67 & $\mathbf{a b}$ & 25,61 & a \\
\hline$-\mathbf{F e}$ & 54 & $\mathbf{a}$ & 32 & $\mathbf{a}$ & 23,94 & $\mathbf{a}$ & 239,33 & $\mathbf{a b}$ & 25,89 & $\mathbf{a}$ \\
\hline$-\mathbf{M n}$ & 56 & $\mathbf{a}$ & 32 & $\mathbf{a}$ & 24,43 & $\mathbf{a}$ & 274,00 & $\mathbf{a}$ & 26,44 & $\mathbf{a}$ \\
\hline$-Z_{\mathbf{n}}$ & 56 & $\mathbf{a}$ & 32 & $\mathbf{a}$ & 23,69 & $\mathbf{a}$ & 262,67 & $\mathbf{a b}$ & 24,77 & $\mathbf{a}$ \\
\hline C.V. $(\%)$ & 7,16 & & 5,42 & & 5,67 & & 6,88 & & 3,07 & \\
\hline \multicolumn{11}{|c|}{ Latossolo Amarelo } \\
\hline Completo & 26 & $\mathbf{a}$ & 23 & $\mathbf{a}$ & 16,23 & $\mathbf{a}$ & 86,00 & c & 18,93 & $\mathbf{a}$ \\
\hline Testemunha & 29 & $\mathbf{a}$ & 23 & $\mathbf{a}$ & 14,06 & $\mathbf{a}$ & 93,00 & $\mathbf{a b c}$ & 14,81 & b \\
\hline$-\mathbf{P} \quad$ & 25 & $\mathbf{a}$ & 24 & $\mathbf{a}$ & 11,87 & $\mathbf{a}$ & 91,00 & bc & 19,26 & $\mathbf{a}$ \\
\hline$-s$ & 25 & $\mathbf{a}$ & 25 & $\mathbf{a}$ & 16,24 & $\mathbf{a}$ & 95,00 & abc & 19,43 & $\mathbf{a}$ \\
\hline$-B$ & 27 & $\mathbf{a}$ & 24 & $\mathbf{a}$ & 13,09 & $\mathbf{a}$ & 107,33 & $\mathbf{a}$ & 19,54 & a \\
\hline$-\mathbf{C u}$ & 25 & $\mathbf{a}$ & 24 & $\mathbf{a}$ & 11,39 & $\mathbf{a}$ & 105,33 & $\mathbf{a b}$ & 19,37 & $\mathbf{a}$ \\
\hline$-\mathrm{Fe}$ & 24 & $\mathbf{a}$ & 24 & $\mathbf{a}$ & 11,63 & $\mathbf{a}$ & 101,50 & $\mathbf{a b}$ & 19,43 & a \\
\hline$-\mathbf{M n}$ & 25 & $\mathbf{a}$ & 25 & $\mathbf{a}$ & 13,33 & $\mathbf{a}$ & 102,67 & $\mathbf{a b}$ & 19,20 & $\mathbf{a}$ \\
\hline$-\mathbf{Z n}$ & 27 & $\mathbf{a}$ & 25 & $\mathbf{a}$ & 13,81 & $\mathbf{a}$ & 103,00 & $\mathbf{a b}$ & 19,71 & $\mathbf{a}$ \\
\hline C.V. $(\%)$ & 9,09 & & 6,02 & & 15,22 & & 5,08 & & 4,85 & \\
\hline \multicolumn{11}{|c|}{ Cambissolo Latossólico } \\
\hline Completo & 65 & b & 62 & $\mathbf{a}$ & 3,88 & $\mathbf{a}$ & 164,33 & $\mathbf{a}$ & 32,40 & $\mathbf{a}$ \\
\hline Testemunha & 72 & $\mathbf{a}$ & 66 & $\mathbf{a}$ & 2,33 & b & 172,33 & $\mathbf{a}$ & 22,71 & b \\
\hline$-\mathbf{P}$ & 66 & b & 63 & $\mathbf{a}$ & 3,71 & $\mathbf{a}$ & 178,67 & $\mathbf{a}$ & 29,84 & $\mathbf{a b}$ \\
\hline$-S$ & 67 & $\mathbf{b}$ & 65 & $\mathbf{a}$ & 4,02 & $\mathbf{a}$ & 181,00 & $\mathbf{a}$ & 30,39 & $\mathbf{a b}$ \\
\hline$-\mathbf{B}$ & 69 & $\mathbf{a b}$ & 64 & $\mathbf{a}$ & 3,85 & $\mathbf{a}$ & 170,00 & $\mathbf{a}$ & 33,40 & $\mathbf{a}$ \\
\hline$-\mathbf{C u}$ & 66 & b & 67 & a & 3,73 & a & 127,00 & a & 30,73 & ab \\
\hline$-\mathrm{Fe}$ & 65 & $\mathbf{b}$ & 65 & $\mathbf{a}$ & 3,68 & $\mathbf{a}$ & 147,00 & $\mathbf{a}$ & 32,17 & $\mathbf{a}$ \\
\hline$-\mathbf{M n}$ & 67 & b & 67 & $\mathbf{a}$ & 3,68 & a & 190,00 & a & 32,18 & $\mathbf{a}$ \\
\hline$-\mathrm{Zn}_{\mathbf{n}}$ & 66 & $\mathbf{b}$ & 61 & $\mathbf{a}$ & 3,78 & a & 194,33 & a & 27,28 & $a b$ \\
\hline C.V. $(\%)$ & 2,40 & & 3,49 & & 3,86 & & 15,97 & & 10,18 & \\
\hline
\end{tabular}

- nas colunas, médias seguidas pela mesma letra, para cada solo, não diferem significativamente pelo teste de Tukey, ao nível de $5 \%$ de probabilidade. 


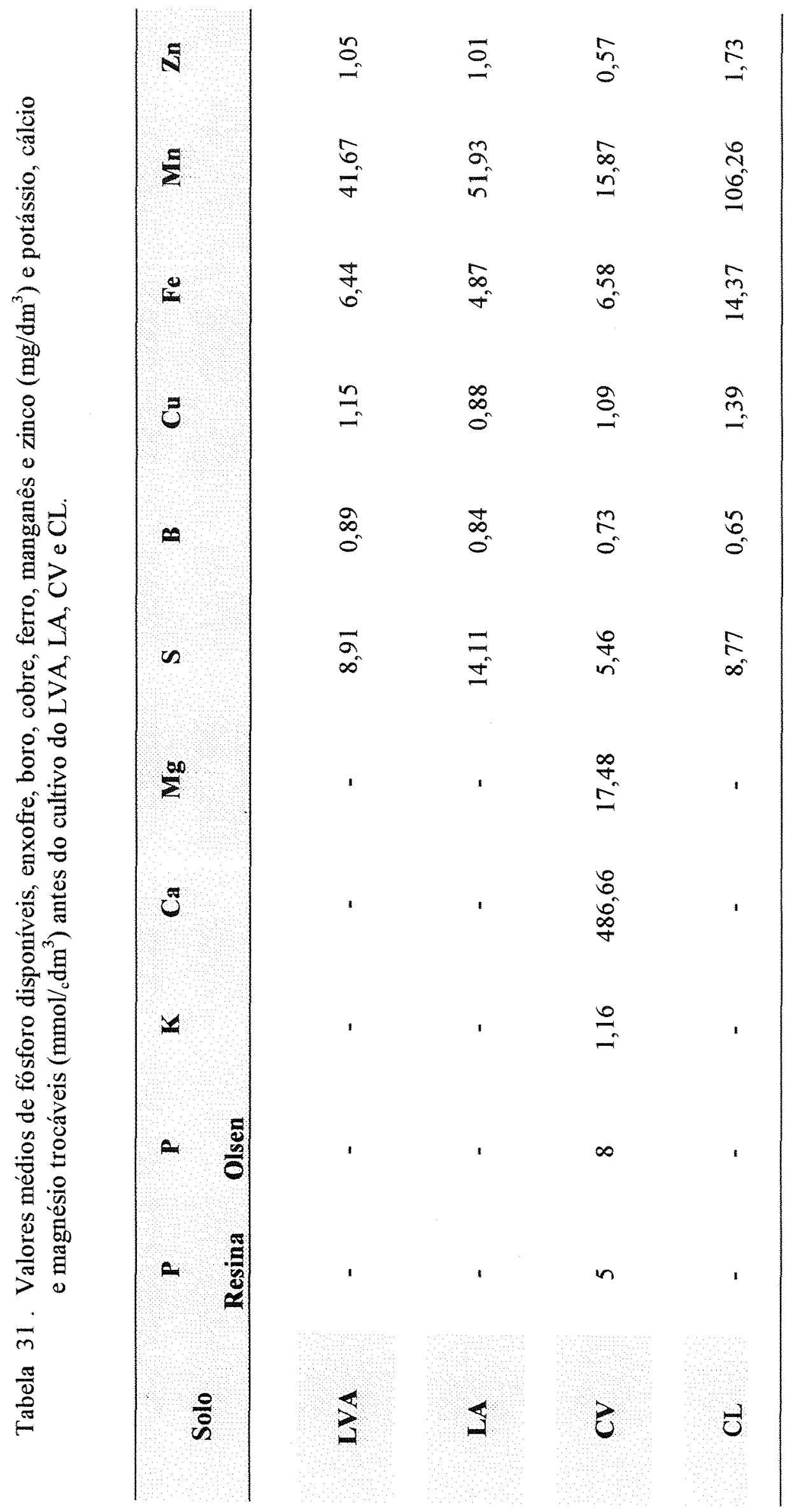




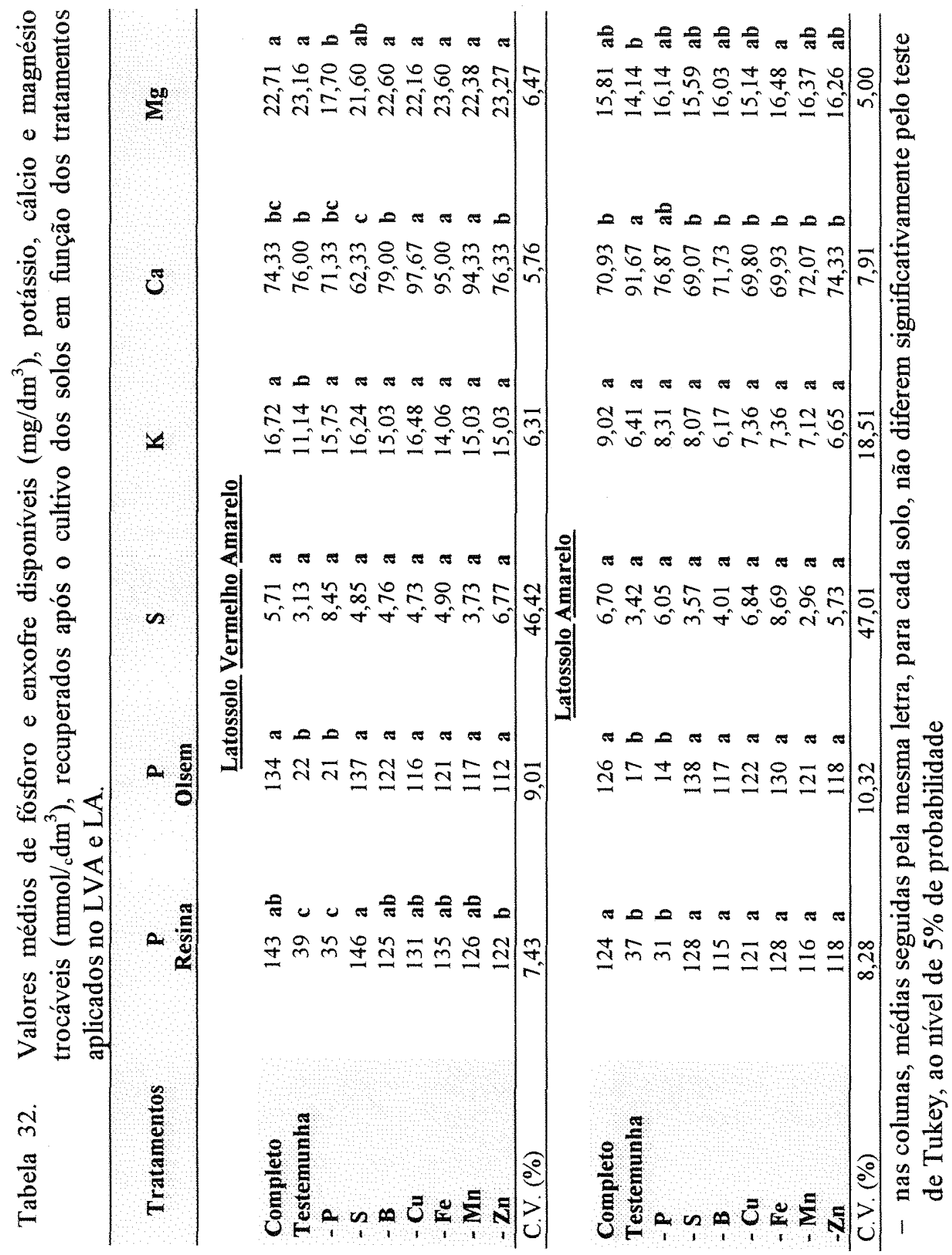




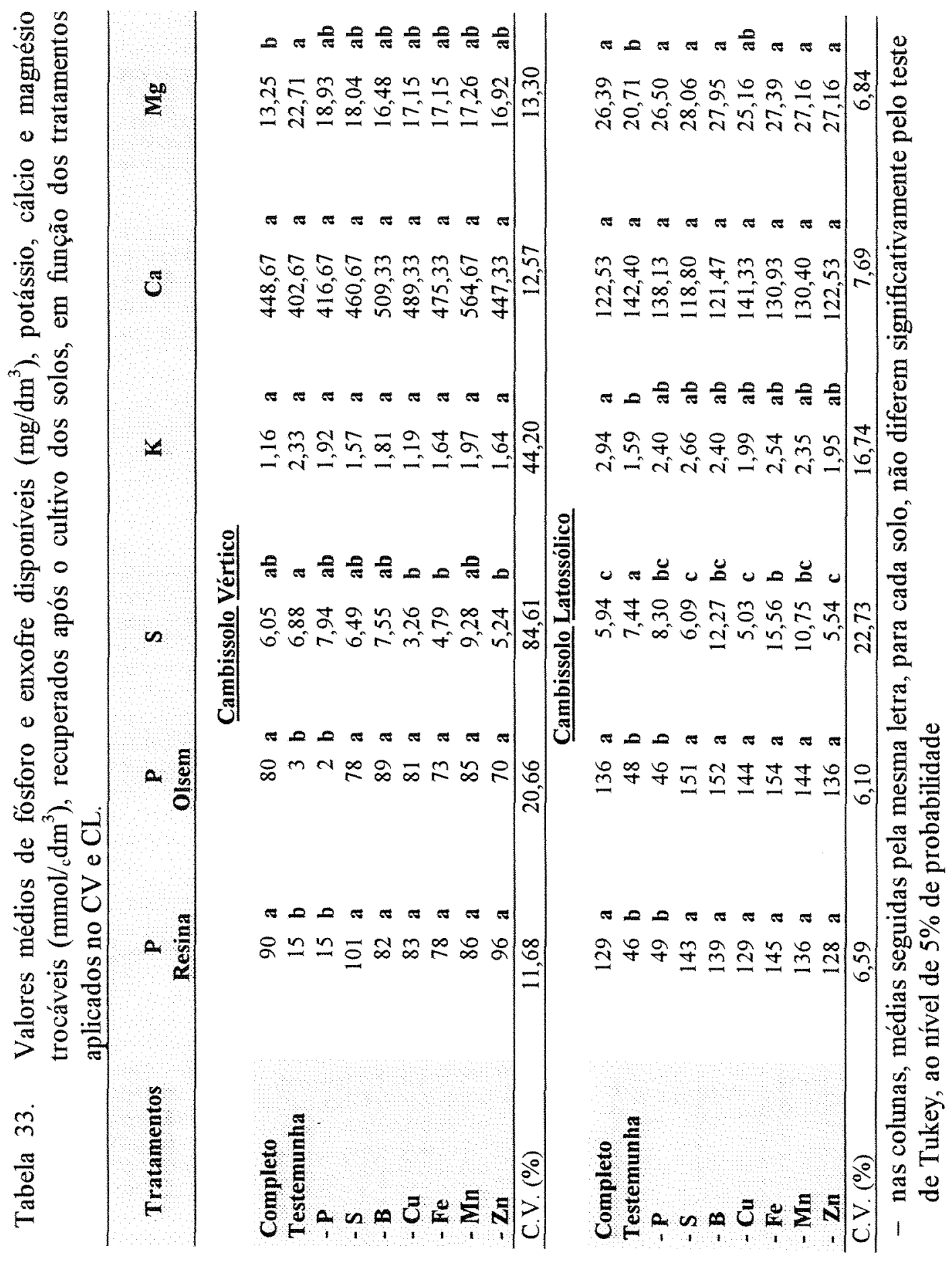




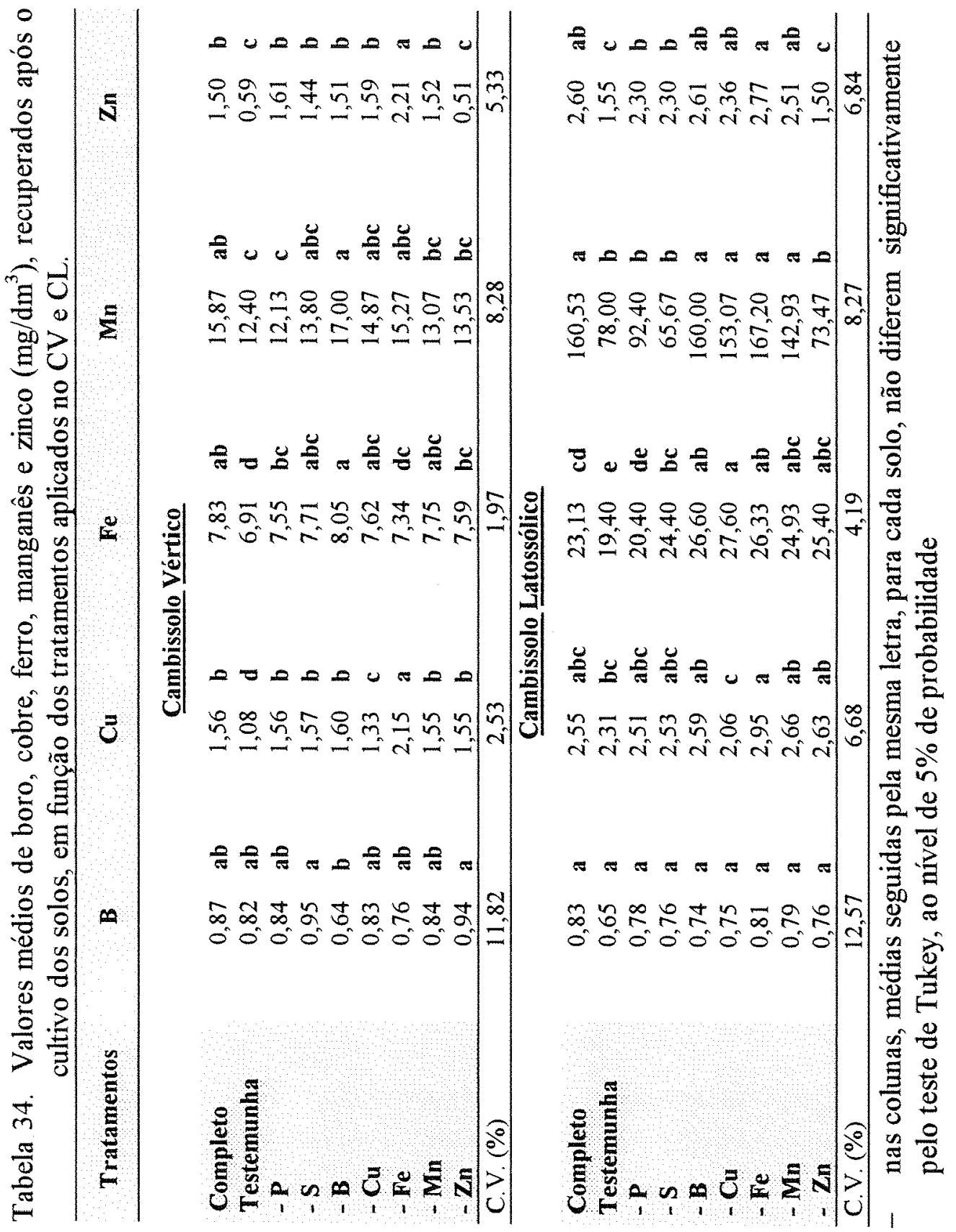




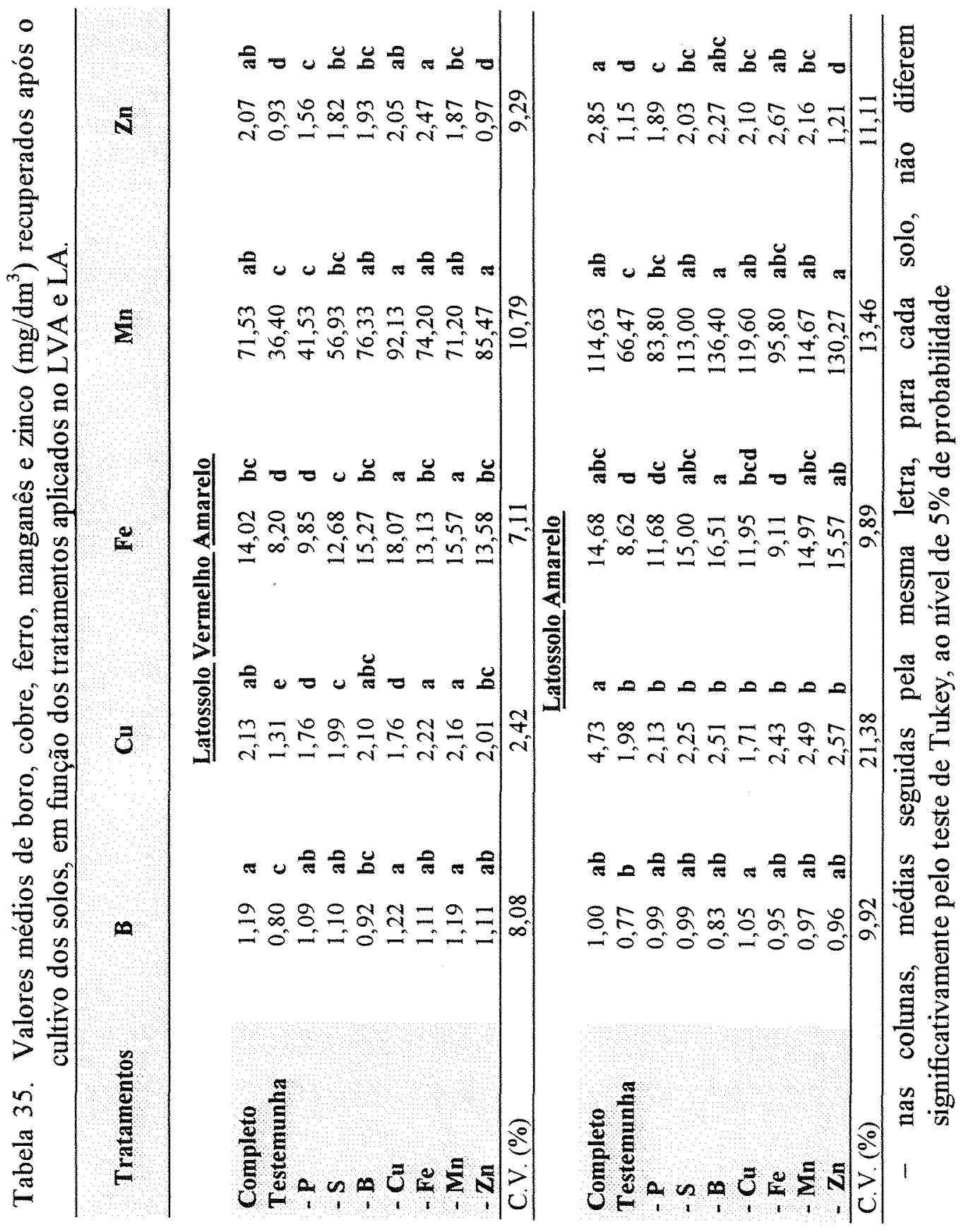




\section{CONCLUSÕES}

Os resultados encontrados permitiram as seguintes conclusões:

- As relações $\mathrm{K} /(\mathrm{Ca}+\mathrm{Mg})$ nos solos $L V A, L A, C V$ e $\mathrm{CL}$, não influenciaram na produção de grãos, matéria seca de: folhas, raizes, caule + ramos, vagem e matéria seca total, na cultura do feijoeiro.

- A produção do feijoeiro, tanto em grãos como em matéria seca de suas partes, não foi influenciada pela mudança da relação Ca/Mg do solo, em ambos os solos.

- Os valores encontrados de potencial de potássio e energia livre de troca no solo $(\Delta G)$, não se ajustaram aos limites de equilíbrio adequado entre cálcio e potássio, deficiência de $\mathrm{K}$ e absorção excessiva de potássio ou deficiência de cálcio sugerido pela literatura.

- Na possibilidade de ocorrer deficiência de potássio nos solos estudados, podese deduzir que o limite inferior de potencial de potássio para que ocorra deficiência, possivelmente seja superior a 2,6, e para $\Delta \bar{G}$ um limite superior menor que -4000 cal/equivalente.

- As equações de regressões entre os valores de $\mathrm{K} /(\mathrm{Ca}+\mathrm{Mg})$ no solo e os dados de potencial de $K$ e $\Delta \bar{G}$, apresentaram antes do cultivo modelos altamente significativos, alcançando coeficientes de determinação $\left(R^{2}\right)$ alto. Todavia, após o cultivo obtiveram-se correlações não significativas.

- Todos os solos estudados apresentaram-se deficientes em fósforo e enxofre. 
- A omissão no LVA de B, Mn e Zn promoveram acréscimos na produção relativa, enquanto a omissão de Cu e Fe decresceram.

- No LA a omissão de $\mathrm{B}, \mathrm{Cu}, \mathrm{Fe}, \mathrm{Mn}$ e $\mathrm{Zn}$ provocaram aumentos na produção relativa.

- Os aumentos de produção relativa no $\mathrm{CV}$ foram devidos a omissão de $\mathrm{B}$ e $\mathrm{Fe}$, enquanto que decréscimos ocorreram em razão da ausência de $\mathrm{Cu}, \mathrm{Mn}$ e Zn.

- A produção relativa no $\mathrm{CL}$ aumentou apenas com a omissão de $\mathrm{Cu}$ e decresceu com a omissão de $\mathrm{B}, \mathrm{Fe}, \mathrm{Mn}$ e $\mathrm{Zn}$. 


\section{REFERÊNCIAS BIBLIOGRÁFICAS}

ALBAREDA, J.M.; HERNANDO, V.; SANCHES CONDE, M. del P. Interaction $\mathrm{Ca} / \mathrm{K}$ en la absorcion de estos elementos por la planta de trigo. I. Influência del $\mathrm{pH}$ en el desarrolo de la planta de trigo. Anales de Edafologia y Fisiologia Vegetal, v.17, p.223-2253, 1958.

ALVAREZ, V.H. Enxofre: critérios de diagnose para solo e planta, correção de deficiência e excesso. In: BORKERT, C.M. ; LANTMANN, H. Enxofre e micronutriente na agricultura brasileira. Londrina: EMBRAPA-CNPS; IAPAR; SBC, 1988. p.31-59.

AMBLER, J.E.; BROWN, J.C. Cause of differential susceptibility to zinc deficiency in two varieties of navy beans (Phaseolus vulgaris L.). Agronomy Journal.v.61, p.41-43, 1969.

BARROWS, H.L.; OZANE, P.G.; SHAW, F.C. Nutrient potential and capacity: I. The concepts of nutrient potential and their application to soil potassium and phosphorus. Australian Journal of Agricultural Researcher, v.16, p.61-76, 1967.

BATAGLIA, O.C. ; RAIJ, B. van. Eficiência de extratores de micronutrientes na análise de solo. Revista Brasileira de Ciência do Solo, v.13, p.105-121, 1989. 
BOISCHOT, P.; COPPENET, M.; HEBERT, J. Fixation de I'aciole phosphorique sur la calcic des sols. Plant and Soil, v.2, p.311-322, 1950.

BOLAN, N.S.; SYERS, J.K.; SUMNER, M.E. Calcium-induced sulfate adsorption by soils. Soil Science Society of America Journal, v.57, p.691-696, 1993.

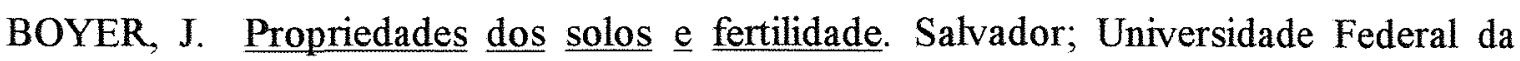
Bahia, 1971, 196p.

BOYOUCOS, G.J. The hydrometer method improved for the mechanical analysis of soil. Soil Science, v.23, p.343-353, 1927.

BRADAWY, R.; BUSSLER, W. Supply and absorption of cation in long term experiment with oats. Potash Review, v. 9/15, p.9, 1968.

BRAGA, J.M. Formas de potássio e estabelecimento de nível crítico para alguns solos do Estado de Minas Gerais. Piracicaba, 1972. 143p. (Tese - Escola Superior de Agricultura "Luiz de Queiroz", Universidade de São Paulo.

BRASIL SOBRINHO, M. de O. C. Levantamento do teor de zinco em alguns solos do município de Piracicaba. Piracicaba, 1966. 96p. Tese Cátedra - Escola Superior de Agricultura 'Luiz de Queiroz”, Universidade de São Paulo.

BRASIL SOBRINHO, M.O.C. Levantamento do teor do boro em alguns solos do Estado de São Paulo. Piracicaba, 1965. 135p. Tese (Livre-docência) - Escola Superior de Agricultura “Luiz de Queiroz”, Universidade de São Paulo.

BRAY, R.H.; KURTZ, L.T. Determination of total organic and available forms of phosphorus in soils. Soil Science, v.59, p.39-45, 1945. 
BRICENO, J.A.; CARVAJAL, J.F. El equilíbrio entre los metales alcalinos y alcalinotérreos en el suelo, associado con la respueta del cafeto al potásio. Turrialba, v. 23, p.56-71, 1973.

BROWN, J.C.; AMBLER, J.E.; CHANEY, R.L.; FOY, C.D. Differential responses of plant genotypes to micronutrients. In: MORTVEDT, J.J.; GIORDANO, P.M.; LINDSAY, W.L., eds. Micronutrients in agriculture. Madison: SSSA, 1972. p.389419.

BUEHRER, T.F. The physico-chemical relationships of soil phosphates. Technical Bulletin. Arizona Agricultural Experiment Station, n.42, p.155-212, 1932.

BULL, L.T. Influência da relação $\mathrm{K} /(\mathrm{Ca}+\mathrm{Mg})$ do solo na produção de matéria seca e na absorção de potássio por gramínea e leguminosas forrageiras. Piracicaba, 1986. 107p. (Tese) - Escola Superior de Agricultura "Luiz de Queiroz", Universidade de São Paulo.

CARMARGO, O.A.; VALADARES, J.M.A.S.; DECHEN, A.R. Efeitos do pH e da incubação na extração do manganês, zinco, cobre e ferro no solo.Revista Brasileira de Ciência do Solo, v.6, p.83-88, 1982.

CARVALHO, B.C.L. de; MENDES, J.E.S.; GOMES, J.C.; SANTOS, D.P.; NUNES, J.A.C.; FRANCO, C.B.; LEITE, J.M. Adubação mineral do feijoeiro (Phaseolus vulgaris L.) no Estado da Bahia. Efeitos de $\mathrm{N}, \mathrm{P}, \mathrm{K}$ e $\mathrm{S}$ e de uma mistura de micronutrientes (B, $\mathrm{Zn}, \mathrm{Cu}$ e $\mathrm{Mo}$ ) nas regiões de Irecê e Tucano. In: SECRETARIA DA AGRICULTURA DA BAHIA. Projeto feijão, Salvador, 1977. p.114-119. 
CASAGRANDE, J.C. O boro em solos do município de Piracicaba. Piracicaba, 1978. 122p. (Dissertação) - Escola Superior de Agricultura "Luiz de Queiroz", Universidade de São Paulo.

CHANG, S.C.; JACKSON, M.L. Solubility product of ion phosphate. Soil Science Society of America Proceedings, v. 21, p.265-269, 1957.

CHAPMAN, N.D.; VANSELOW, H.P. Boron deficiency and excess. Davis: University of california, Dept. of Soils and Plant Nutrition, 1955. 4p.

CHARUDHRY, F.M.; LONERAGAN, J.F. Zinc absorption by wheat seedling and the nature of its inhibition by alkaline earth cations. Journal Experimental Botany, v.23, p.552-560, 1972.

CHAUDHRY, F.M.; WALLACE, A. Zinc uptake by rice as affected by iron and a chelator of ferrous irion. Plant and Soil, v. 45, p.697-700, 1976.

COBRA NETO, A.; ACCORSI, W.R.; MALAVOLTA, E. Estudos sobre a nutrição mineral do feijoeiro (Phaseolus vulgaris L., var, Roxinho). Anais da Escola Superior de Agricultura "Luiz de Queiroz", v.28, p.257-274, 1971.

COMISSÃO ESTADUAL DE FERTILIDADE DO SOLO. Manual de adubação e calagem para o estado da Bahia. 2.ed. Salvador: CEPLAC; EMATER-BA; EPABA; NITROFERTIL, 1989. 173p.

COOK, R.L; MILLAR, C.E. Some soil factors affecting boron availability. Soil Science Society of America Proceedings, v. 4, n.3, p.297-301, 1939. 
CORDEIRO, D.A. Emprego de técnicas de marcação no estudo da interrelação calagem - adubação potássica em solos cultivados com cana-de-açúcar. Piracicaba, 1978. 102p. (Tese) - Escola Superior de Agricultura "Luiz de Queiroz", Universidade de São Paulo.

CRUZ, M.C.P.; FERREIRA, M.E. Seleção de métodos para avaliação do boro disponível em solos. Pesquisa Agropecuária Brasileira, v. 19, p.1457-1464, 1984.

CUNHA, T.J. F. Matéria orgânica de alguns solos de Irecê-BA: Sua dinâmica e algumas relações pedogenéticas. Salvador, 1992. 221p. (Dissertação) - Universidade Federal da Bahia.

DANTAS, H.S. Manganês e cátions permutáveis na unidade de Utinga. Pesquisa Agropecuária Brasileira, Série Agronomia, v.6, p.30, 1971.

DUETE, W.L.C. Avaliação da fertilidade de quatro solos do recôncavo baiano para cultura do feijão (Phaseolus vulgaris L.). Viçosa, 1988. 94p. (Dissertação) Universidade Federal de Viçosa.

EL-HUSNY, J.C. Limitações nutricionais para cultura do feijoeiro (Phaseolus vulgaris L.) em um solo do norte de Minas Gerais. Lavras, 1992. 151p. (Dissertação) Escola Superior de Agricultura de Lavras.

ELGALA, A.M.; ISMAIL, H.S.; OSSMAN, M.A. Critical levels of iron, manganese and zinc in Egyptian soils. Journal of Plant Nutrition, v. 9, n. 3/7, p.267-280, 1986. 
EMPRESA BRASILEIRA DE PESQUISA AGROPECUÁRIA - Centro Nacional de Pesquisa de Arroz e Feijão. Programa Nacional de Pesquisa do Feijão. Brasilia, 1981. $117 \mathrm{p}$.

EMPRESA BRASILEIRA DE PESQUISA AGROPECUÁRIA. Sistema brasileiro de classificação de solos. Terceira aproximação. Rio de Janeiro: SNLCS, 1988. 122p.

EMPRESA DE ASSISTÊNCIA TÉCNICA E EXTENSÃO RURAL DA BAHIA. Avaliação dos recursos naturais da região do PDRJ-Irecê. Salvador: EMATER-BA; CAR, 1985. 172p.

ERNESTO SOBRINHO, F. Caracterização, gênese e interpretação para uso de solos derivados de calcário da região da Chapada do Apodi, RN. Viçosa, 1980. 133p. (Dissertação) - Universidade Federal de Viçosa.

EVANS, E. Studies in the mineral nutrition of sugarcane in British Guiana. II. The mineral status of sugarcane as revealed by foliar analysis. Tropical Agriculture, v. 32, p. 295-322, 1955.

EVANS, L.T.; RUSSELL, E.W. The absorption of humic and fulvic acids by clays. Journal of Soil Science, v.10, p. 119-132, 1959.

FAHAD, A.A. Movement of manganese- 54 in calcareous soils as affected by leaching solution, lime content, salinization, and sterilization. Soil Science Society of American Journal, v. 51, p.1487-1492, 1987.

FANNING, C. Fertilization. In: DRY bean production haudbook. Fargo: North Dakota Cooperative Extension Service, 1985. p.11-13. (Publication A-602). 
FASSBENDER, H.W. La fertilización del frijol (Phaseolus spp). Turrialba, v.17, p.46$52,1967$.

FASSBENDER, H.W. \& LAROCHE, L.A. The nutritive potentials of soil and proportions of K:Ca:Mg in tomato plants. Plant and Soil, v.28, n.3, p.431-441, 1968.

FASSBENDER, H.W. Equilibrios cationicos y disponibilidad de potasio en suelos de América Central. Turrialba, v.22, n.4, p.388-397, 1972.

FERRARI NETO, J. Limitações nutritionais para o colonião (Panicum maximum Jacq) e braquiária (Brachiaria decumbens Stapt.) em Latossolo da região noroeste do Estado do Paraná. Lavras. 1991. 126p. (Dissertação) - Escola Superior de Agricultura de Lavras.

FORNO, D.A.; YOSHIDA, S.; ASHER, C.J. Zinc deficiency in rice. I. Soil factors associated with the deficiency. Plant and Soil, v. 42, p.537-550, 1975.

FORTUNATO, F.F. Relação rocha matriz/material de origem numa sequência de solos desenvolvidos de arenito, argilito e calcário em região de clima semi-árido Iraquara-BA. Salvador, 1982. 139p. (Dissertação) - Instituto de geociências, Universidade Federal da Bahia.

FUZZATO, M.G.; FERRAZ, C.A.M. Correlação entre o efeito da adubação potássica no algodoeiro e análise química do solo. Bragantia, v. 26, p.345-352, 1967.

GARDNER, R; KELLEY, O.J. Relations of $\mathrm{pH}$ to phosphate solubility in calcareous soils. Soil Science, v.50, p.91-102, 1940. 
GETHING, P.A. Potasio del suelo - Estudio de recientes investigaciones. Revista de la Potasa, v.16, n.22, p.1-11, 1962.

GUAZZELLI, J.R. A pesquisa de feijão no Brasil, situação atual e perspectivas. In: CURSO DE PRODUÇÃO DE FEIJÃO, 2., Goiânia, 1983. Trabalhos... Goiânia:EMBRAPA; CNPAF; CIAT, 1983.

GUPTA, R.K. ELSHOUT, S.V.D.; ABROL, I.P. Effect of pH on zinc adsorptionprecipitation reactions in an alkali soil. Soil Science, v.143, n.3, p. 198-204, 1987.

GUPTA, V. Relationship of total and not - water soluble boron and fixation of added boron, to properties of podzol soils. Soil Science Society of America Proceedings, v.32, p.45-48, 1968.

GUPTA, V.C. Boron nutrition of crops. Advances in Agronomy, v.31, p.273-307, 1979.

HAAG, H.P.; MALAVOLTA, E.; GARGANTINI, G.; GARCIA BLANCO, H. Absorção de nutrientes pela cultura do feijoeiro. Bragantia. v.26, n.30, p.281-391, 1967.

HIROCE, R; GALLO, J.R. Efeito do enxofre na produção de soja. Bragantia, Campinas, v.31, nota 3, p.11-12, 1972.

HOROWITZ, A.; DANTAS, H. da S. Boro disponível nos solos da zona litoral - Mata de Pernambuco. Pesquisa Agropecuária Brasileira, , v.8, n.7, p. 163-168, 1973.

HSU, P.H.; JACKSON, M.L. Inorganic phosphate transformations by chemical weathering in soils as influenced by pH. Soil Science, v.90, p.16-24, 1960. 
HUFFMAN, E.O. Reaction of phosphate in soil: recent research by TVA. Proceedings. Fertilizer Society of London, v.71, p.5-35, 1962.

JACKSON, M.L. Soil chemical analysis advanced cource. Madison: University of Wisconsin, Dept. of Soils, 1956.

JACOB, H.; VEXKUELL, H.V. Fertilizer use, nutrition and manuering of tropical crops. 3 ed. Hannover:Verlogsgesellschaft fuer Ackerbau, 1963. 566p.

JONES, H.E.; SCARSETH, G.D. The calcium-boron balance in plants as related to boron needs. Soil Science, v.57, p.15-24, 1944.

KEREN, R.; BINGHAM, F.T. Boron in water, soils and plant. Advances in Soil Science . v.1, p.229-276, 1985.

KEY, J.L.; KURTZ, L.T. Response of corn and soybeans to magnesium fertilizers. Agronomy Journal , v.52, n.5, p.300-301, 1960.

KHASAWNEH, F.E. Solution ion activily and plant growth. Soil Science Society of America Proceedings, v.35, p.426-446, 1971.

KILMER, V.J.; NEARPASS, D.C. Determination of available sulfur in soils. Soil Science Society of America Proceedings, v.24, p.337-340, 1960.

KLANT, E. Calagem "maciça" e disponibilidade de manganês. Universidade Federal do Rio Grande do Sul, Faculdade de Agronomia e Veterinária, 1969. 4p. 
LAROCHE, F.A. A calagem em solos tropicais de clima úmido. Fitotecnia Latino Americana, v.3, p.83-97, 1966.

LARSEN, S. Soil phosphorus. Advances in Agronomy,v. 19, p.151-210, 1967.

LINDSAY, W.L. Chimica equilibria in soils, New York:Willey, 1979. 449p.

LINDSAY, W.L. Inorganic phase equilibria of micronutrients in soils. In: SYMPOSIUM ON MICRONUTRIENTS IN AGRICULTURE, Muscle Shoals, 1971. Proceedings... Madison: SSSA, 1972, p.41-57.

LINDSAY, W.L.; FRAZIER, A.W.; STEPHENSON, H.F. Identification of reaction products from phosphate fertilizer in soil. Soil Science Society of America Proceedings, v.26, p.446-452, 1962.

MACKENZIE, A.F.; AMER, S.A. Reactions of iron, aluminum and calcium phosphates in six Ontario soils. Plant and Soil, v. 21, p. 17-25, 1964.

MALAVOLTA, E. Estudos químicos agrícolas sobre o enxofre. Anais da Escola Superior de Agricultura "Luiz de Queiroz", v.9, p.39-130, 1952.

MALAVOLTA, E. Manual de química agrícola. São Paulo: Agronômica Ceres, 1976. $528 \mathrm{p}$.

MALAVOLTA, E. Nutrição e adubação. In: SIMPÓSIO BRASILEIRO DE FEIJÃO, 1, Campinas, 1972. Anais.... Viçosa: UFV, 1972. v1, p.211-242.

MALAVOLTA, E. ; MURAOKA, T. Avaliação do estado nutricional e da fertilidade do solo. Os micronutrientes no solo. Piracicaba: CENA/USP, 1991. 7p. 
MALAVOLTA, E. Elementos de nutrição mineral de plantas. São Paulo, Editora Agronômica Ceres, 1980. 251p.

MALAVOLTA, E.; MURAOKA, T. Avaliação do estado nutricional e da fertilidade do solo: métodos de vegetação de diagnose por subtração em vasos. Piracicaba, CENA-USP, 1985. 7p.

MALAVOLTA, E.; VITTI, G.C.; OLIVEIRA, S.A. Avaliação do estado nutricional das plantas: princípios e aplicações. Piracicaba: Associação Brasileira para Pesquisa da Potassa e do Fosfato, 1989. 210p.

MANDAL, L.N.; HALDER, M. Influence of phosphorus and zinc application on the availability of zinc, copper, iron, manganese and phosphorus in waterlogged rice soils. Soil, v.130, p.251-257, 1980.

McGEORGE, W.T.; BREZEALE, J.F. The relation of phosphate availability and carbon dioxide to the fertility of calcareous soils. Technical Bulletin. Arizona Agricultural Experiment Station, n.36, p.361-412, 1931.

MEDVEDEVA, D.P. Influence of calcium on potassium uptake by plants and the potassium potential of the soil. Society Soil Science, v.8, p.1120-1129, 1968.

MENGEL, K. GEURTZEN G. Iron chloroses on calcareous soils. Alkaline nutritional conditions as the cause of the chlorosis. Journal of Plant Nutrition. v. 9, p.161$174,1986$. 
MISI, A.; KYLE, J.R. Ambiente sedimentar e origem das concentrações de sulfetos e de fosfato da região de Irecê-Lapão (grupo Una, Proterozóico superior), Bacia do Irecê-Bahia. In: CONGRESSO BRASILEIRO DE GEOLOGIA, 36, Natal, 1990. Boletim de Resumos. Natal, 1990. p. 120.

MONIZ, A.C. Elementos de pedologia. São Paulo:EDUSP, 1972. 459p.

MORAIS, F.I.O.; CABALA, F.P. Efeitos dos equilíbrios entre cálcio, magnésio e potássio no crescimento do cacaueiro. Theobroma, v.1, p.21-32, 1971.

MOSS, P. ; COULTER, J.K. The potassium status of west Indian Volcanic Soils. Journal of Soil Science. v.15, p.284-298, 1964.

MOURA FILHO, W. Curso de solos e adubos; fisica, gênese e morfologia. Viçosa:UFV, 1965. 106p.

MURAOKA, T.; NEPTUNE, A.M.L.; NASCIMENTO FILHO, V.F. Avaliação da disponibilidade de zinco e de manganês do solo para o feijoeiro. I. Zinco. Revista Brasileira de Ciência do Solo, v.7, p.167-175, 1983a.

MURAOKA, T.; NEPTUNE, A.M.L.; NASCIMENTO FILH0, V.F. Avaliação da disponibilidade de zinco e de manganês do solo para o feijoeiro. II. Manganês. Revista Brasileira de Ciência do Solo, v.7, p.177-182, 1983b.

OLIVEIRA, I.P. de; THUNG, M.D.T. Nutrição mineral. In: Zimmermann, M.J. de O.; Rocha, M.; Yamada, T. Cultura do feijoeiro: fatores que afetam a produtividade. Piracicaba: Associação para Pesquisa da Potassa e do Fosfato, 1988. p.175-212. 
OLSEN, S.R. Micronutrient interactions. In: SYMPOSIUM ON MICRONUTRIENTS IN AGRICULTURE, Muscle Shoals, 1971. Proceedings... Madison:SSSA, 1972. p. 243-264.

OLSEN, S.R. ; KHASAWNER, F.E. Use and limitations of physical-chemical criteria for assessing the status of phosphorus in soils. In: KHASAWNEH, F.E.; SAMPLE, E.C.; KAMPRATH, E.J., eds. The role of phosphorus in agriculture. Madison, ASA, 1980. p.361-410.

OLSEN, S.R.; COLD, C.V.; WATANABE, F.S.; DEAN, L.A. Estimation of available phosphorus in soils by sodium bicarbonate. Washington: USDA, 1954. (USDAUSGPO. Circular, 939).

OLSON, R.U.; BERGER, K.C. Boron fixation as influenced by $\mathrm{pH}$, organic matter content, and other factors. Soil Science Society of America Proceedings, v.11, n. 5, p. 216-220, 1946.

OMAR, M.A; EL KOBBIA, T. Some observations on the interrelationships of potassium and magnesium. Soil Science, v.101, p.437-440, 1966.

PANDEI, M. Uptake and accumulation of $\mathrm{K}, \mathrm{Ca}$ and $\mathrm{Mg}$ by plants at increasing concentrations of one the cations in the medium. Soils and Fertilizers, v.35, p. $1425,1972$.

PATHAK, A.N.; KABRA, Y. Antagonism between potassium, calcium and magnesium in several varieties of hybrid corn. Soils and Fertiizersv.35, p.3469, 1972.

PETERSON, L.A.; NEWMAN, R.C. Influence of soil $\mathrm{pH}$ on the availability of abbed boron. Soil Science Society of American Journal, v.40, n.2, p.280-282, 1976. 
PIERRE, W.H.; BOWER, C.A. Potassium absorption by plants as affected by cationic relationships. Soil Science, v.55, p.23-36, 1943.

QUAGGIO, J.A.; RAIJ, B. van. Comparação de métodos rápidos para a determinação da matéria orgânica em solos.Revista Brasileira de Ciência do Solo, v.3, p.184$187,1979$.

RACZ, G.J.; SOPER, R.J. reaction products of orthophosphates in soils containing varying amounts of calcium and magnesium. Canadian Journal of Soil Sciience, v. 48, p. $265-269,1967$.

RAGLAND, J.L.; SEAY, W.A. The effects of exchangeable calcium on the retention and fixation of phosphorus by clay fractions of soil. Soil Science Society of America Proceedings, v.21, p.261-264, 1957.

RAIJ, B. van; QUAGGIO, J.A. Métodos de análise de solos para fins de fertilidade. Campinas: Instituto Agronômico de Campinas, 1983, 31p. (IAC. Boletim Técnico, 81)

RAIJ, B. van. Calibração do potássio trocável em solos para feijão, algodão e cana de açúcar. Ciência e Cultura, v. 26, n.6, p.575-579, 1974.

RAIJ, B. van; QUAGGIO, J.A.; CANTARELLA, H.; FERREIRA, M.E.; LOPES, A.S.; BATAGLIA, O.C. Análise química do solo para fins de fertilidade. Campinas: Fundação Cargill, 1987. 170p.

RAVIKOVITCH, S. Influence of exchangeable cations on the availability of phosphorus in soils. Soil Science, v.47, p.357-366, 1939. 
RECOMENDAÇÕES de adubação e calagem para o Estado de São Paulo. Boletim Técnico, n.100, p.1-107, 1985.

REISENAUER, H.M.; WALSH, L.M.; HOEFT, R.G. Testing soils for sulfur, boron, molybdenum and chlorine. In: WALSH, L.M.; BEATON, J.D., eds. Soil testing and plant analysis. Madison: SSA, 1973, p.173-200.

RESENDE, M. Pedologia e fertilidade do solo: interações e aplicações. Brasília. Ministério da Educação; Lavras:ESAL; Piracicaba: POTAFOS, 1988, 81p.

RESENDE, M. Pedologia - Viçosa, Universidade Federal de Viçosa, 1982. 100p.

RIBEIRO, A.C.; TUCUNANGO SARABIA, W.A. Avaliação de extratores para zinco e boro disponíveis em latossolos do Triângulo Mineiro. Revista Brasileira de Ciência do Solo, v.8, p.85-89, 1984.

RIBEIRO, H.C.; BRAGA, J.M. Adsorção de boro pelo solo. Experientiae, v.17, p.293-310, 1974.

RICHARDS, L.A. Diagnosis and improvement of saline and alkali soils. Washington: USDA, US Salinity Laboratory, 1954. 160p. (Hbk, 60).

ROCHA, M.; MALAVOLTA, E. Perspectiva de demanda, comercialização e produção industrial de enxofre e micronutrientes para a agricultura. In: BOKERT, C.M.; LANTMANN, A. Enxofre e micronutrientes na agricultura brasileira. Londrina: EMBRAPA-CNPSO; IAPAR; SBCS, 1988. p.277-309. 
ROCHE, R; GRIERE, L.; BABRE; CALBA, H.; FALLAVIER, R. $\underline{\text { fósforo nos solos }}$ tropicais: apreciação dos níveis de carência e das necessidades de fósforo. Paris: Institut Mondial de Phosphate,1980. B.2, 48p

ROMHELD, V.; MARSCHNER, H. Mobilization of iron in the rhizosphere of different plant species Advances in Plant Nutrition, v.2, p.155-204, 1986.

RUSSELL, J.E.; RUSSEL, W.E. Las condiciones del suelos y el crescimiento de las plantas. Madrid: Aguilar, 1968. 801p.

SAKAL, R.; SINGH, B.P.; SINGH, A.P. Determination of critical limit of zinc in soil and plant for predicting response of rice to zinc application in calcareous soil. Plant and Soil, v.66, p.129-132, 1982.

SANCHEZ CONDE, M.P.S. Evaluación de la interaction Ca-K em plantas de lechuga de diferente desarollo. Agrochimica, v.24, p.330-57, 1980.

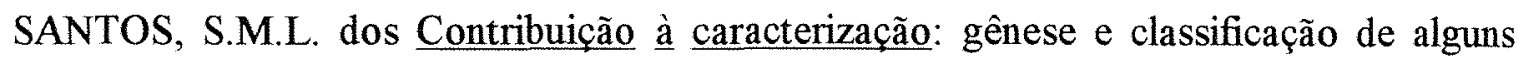
solos desenvolvidos sobre calcários da região de Irecê-Xique-Xique-BA, 1976. 188p. (Dissertação)- Instituto de Geociências, Universidade Federal da Bahia.

SCHALSCHA, E.B.; BINGHAM, F.T.; CALINDO, G.G.; GALVAN, H.P. Boron adsorption by vulcanic ash soils in southern Chile. Soil Science, v.116, n.2, p.70-76, 1973.

SCHWARTZ, R. Magnesium. In: Smith, ed. Trace minerals in foods. New York: Marcel Dekker, 1988. p.117-155. 
SEN GUPTA, M.B.; CORNFIELD, A.H. Phosphorus in calcareous soil. I. The inorganic phosphate fractions and their relation to the amount of calcium carbonate present. Journal of Science of Food and Agriculture, v.13, p.652-658, 1962.

SOARES, E. Influência da relação entre teores trocáveis de cálcio e magnésio do solo na absorção de potássio pelo centeio (Secale cereale L.). Piracicaba. 1975. 73p. (Dissertação) - Escola Superior de Agricultura "Luiz de Queiroz", Universidade de São Paulo.

SOARES, E. Influência do teor de potássio trocável do solo na absorção de cálcio e magnésio pela soja. Piracicaba. 1978. 116p. (Tese) - Escola Superior de Agricultura "Luiz de Queiroz", Universidade de São Paulo.

SOARES, E.; BULL, L.T.; LIMA, L.A. Efeito da relação Ca:Mg:K, da saturação em bases e da adubação nitrogenada na cultura do trigo cultivado em solo Latossolo Vermelho Escuro. Revista de Agricultura, v.63, p.225-233, 1988.

SOARES, E.; LIMA, L.A.; MISCHAN, M.M.; MELLO, F.A.F.; BOARETTO, A.E. Efeito da relação entre teores trocáveis de $\mathrm{Ca}$ e $\mathrm{Mg}$ do solo na absorção de $\mathrm{K}$ por plantas de centeio . Revista de Agricultura, v.58, p.315-330, 1983.

TEDESCO, M.J.; VOLKWEISS, S.J.; BOHNEN, H. Análises de solo, planta e outros materiais. Porto Alegre: Universidade Federal do Rio Grande do Sul, Depto de Solos, 1985. 188p. (Boletim técnico, 5).

THOMAS, G.H.; PEASLEE, D.E. testing soils for phosphorus. In: WALSH, L.M. ; BEATON, J.D., eds. Soil Testing and Plant Analysis. Madison: SSSA, 1973. p.115-132. 
TISDALE, S.L.; NELSON, W.L. Soil fertility and fertilizers.3.ed. New York: MacMillan, 1975. 694p.

TISDALE, S.L.; NELSON, W.L.; BEATON, J.D. Soil fertility and fertilizers. 4 ed. New York: MacMillan, 1985. 754p.

VALADARES, J.M.A.S.; CATANI, R.A. Zinco em solos do Estado de São Paulo. Bragantia, v.34, n.5, p.134-139, 1975.

VERDADE, F. da C. Análise química total. In: Moniz, A.C., coord. Elementos de pedologia. São Paulo, EDUSP, 1975, cap. 17, p.209-221.

VETTORI, L. Métodos de análise de solos. Rio de Janeiro: Ministério da Agricultura, Equipe de Análise de Solos, 1969. (EPE-MA. Boletim, 7).

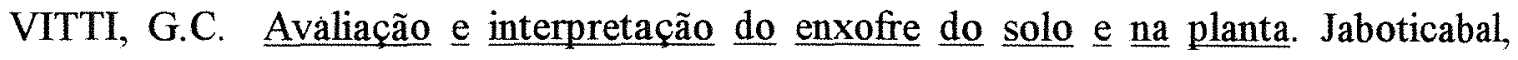
FUNEP, 1989. 37p. (Boletim técnico).

VITTI, G.C.; FORNASIERI FILHO, D.; FERREIRA, M.E.; RAGAZZI, D.; HING, L.T. Efeito de doses de gesso na cultura do feijoeiro (Phaseolus vulgaris L.). Revista de Agricultura, v. 57, n.3, p.119-132, 1982.

VOSE, P.B.; JONES, D.G. The interaction of manganese and calcium on nodulation and growth in varieties of Trifolium repens. Plant and Soil, v. 18, p.372-385, 1963.

WAADINGTON, D.V.; MOBERG, E.L.; DUICH, J.M. Effect of N source, K source, and $\mathrm{K}$ rate on soil nutrient levels and Bentgrass, Agrostis palustris Hucls. Agronomy Journal, v.64, p.562-566, 1972. 
WHITE, J.L.; JACKSON, M.L. Glycerol solvation of soil clays for x-ray diffraction analysis: Soil Science Society of America Proceedings, v.11, p.150-154, 1947.

WIKLANDER, L. Cation and anion exchange phenomina. In: BEAR, F.E., ed. Chemistry of the soil. 2. ed. New York, Reinhold, 1964. p.163-205.

WOODRUFF, C.M. Ionic equilibria between clay and dilute salt solution. Soil Science Society America Proceedings, v.19, p.36-40, 1955a.

WOODRUFF, C.M. The energies of replacement of calcium by potassium in soils. Soil Science Society of America Proceedings . v.19, p.167-171, $1955 \mathrm{~b}$.

WOODRUFF, C.M.; McINTOSH, J.L. Testing soils for potassium. In: $7^{\text {th }}$ INTERNATIONAL CONGRESS SOIL SCIENCE, Madison, 1960. Proceedings.... Madison, 1960, v.4, p.80-85.

YANG, M.; ROMHELD, V.; MARSCHNER. Effect of bicarbonate and root zone temperature on uptake de $\mathrm{Zn}, \mathrm{Fe}, \mathrm{Mn}$ and $\mathrm{Cu}$ by different rice cultivars (Oryza sativa L.) grown in calcareous soil. Plant Nutrition, p.657-660, 1993.

YASREBI, J.; KARIMIAN, N.; MAFTOUN, M.; ABTAHI, A.; SAMENI, A.M. Distribution of zinc forms in highly calcareous soils as influenced by soil physical and chemical properties and application of zinc sulphate. Communications in Soil Science and Plant Analysis, v.25, p.2133-2146, 1994.

YORK, E.T. Jr; BRADFIELD, D.; PEECH, M. Influence of lime and potassium on yield and cation composition of plants. Soil Science, v.77, p. 53-65, 1954. 